Науковий вісник Чернівецького національного університету: Збірник наукових праць. Вип. 557-558. Економіка. - Чернівці: Чернівецький нац. ун-т., 2011. - 188с.

Naukovy Visnyk Chernivetskoho natsionalnoho Universitetu: Zbirnyk Naukovyh Prats. Vyp. 557-558. Ekonomika. - Chernivtsi: ChNU, 2009. - 188 p.

У науковому віснику представлені різноманітні аспекти розвитку інституційних систем національних економік. Розглядаються актуальні проблеми історії економічної науки, теорії і практики економічного зростання, функціонування фінансового механізму, маркетингової системи, економіки підприємства та організації підприємництва, міжнародної економіки та економічної кібернетики.

Розрахований на науковців, фахівців-практиків, викладачів навчальних закладів, аспірантів, студентів усіх, кого цікавлять теоретичні та прикладні аспекти економічних досліджень.

In the scientific journal presents various aspects of the institutional systems of national economies. Actual problems of the history of economic science, theory and practice of economic growth, the functioning of the financial mechanism, marketing systems, enterprise economics and business organization, international economics and economic cybernetics.

Intended for researchers, practitioners, teachers of educational institutions, graduate students - all who are interested in theoretical and applied aspects of economic research.

\title{
Редколегія випуску:
}

Нікіфоров П.О., доктор економічних наук, професор (науковий редактор);

Лопатинський Ю.М., доктор економічних наук (заступник наукового редактора);

Запухляк B.M., кандидат економічних наук, доцент (відповідальний секретар);

Григорків В.C., доктор фізико-математичних наук, професор;

Євдокименко B.К., доктор економічних наук, професор;

Ковальчук T.M., доктор економічних наук, професор;

Комарницький І.Ф., доктор економічних наук, професор;

Кузьмін O.C., доктор економічних наук, професор;

Лютий I.O., доктор економічних наук, професор;

Саблук П.Т., доктор економічних наук, професор;

Юрій C.I., доктор економічних наук, професор.

Сторощук Б.Д., кандидат економічних наук, доцент.

Друкується за ухвалою Вченої ради

Чернівецького національного університету імені Юрія Федьковича

Свідоцтво Міністерства України у справах преси та інформації

№ 2158 серія КВ від 21.08.1996

Загальнодержавне видання

Внесено до нового Переліку наукових фахових видань України згідно постанови президії ВАК України від 14 квітня 2010 р. № 1-05/3

(Бюлетень ВАК України, № 5, 2010, cm. 10)

(C) Чернівецький національний університет, 2011 
УДК 33(73)(092)Шумпетер:378.4(477.85-25).ЧНУ

\section{(C) Сторощук Б.Д., Дячук М.П., 2011 \\ Чернівецький національний університет імені Юрія Федьковича, м.Чернівці \\ ЙОЗЕФ АЛОЇЗ ШУМПЕТЕР І ЧЕРНІВЕЦЬКИЙ УНІВЕРСИТЕТ}

100 років тому в 1909-1911 роках в Чернівиях розпочав свою професорську кар'єру молодий талановитий австрійський вчений Йозеф Алої Шумпетер, котрий заслужсив світову славу, залишив помітний слід в соиіологічній науиі, став одним з найвидатніших економістів XX $\mathrm{cm}$.

Вагомою складовою багатої наукової спадщини Шумпетера є праці чернівецьького періоду його життя, які розкривають джерела формування наукових поглядів та економічних теорій вченого.

Гордістю іноземних фондів університетської книгозбірні австрійського періоду є тогочасні видання робіт Й. Шумпетера, котрих не мають інші бібліотеки України, а в радянський період тільки окремі з них зберігались у московських спецсховах.

Шлях до світового визнання Шумпетера був непростим, $з$ перших кроків наукового життя йому доводилося відстоювати свої погляди серед представників історично складної тогочасної консервативної економічної школи.

Надзвичайна широта поглядів ученого 3 самого початку формувалася завдяки вихованню і різносторонній освіті у престижному Терезіанському ліцеї та у Віденському університеті протягом 1901-1906 рр. на факультеті права і політичних наук, де викладались елітні курси з питань юриспруденції, економіки, статистики. Тут, потрапивши в столичне інтелектуальне середовище, він разом $з$ у майбутньому відомими соціалістами Р. Гільфердінгом, О. Бауером вчився в таких видатних представників австрійської та німецької економічної школи, як Ф. Візер, $€$. Філіпович, С. Бем-Баверк, Л. Мізес.

Будучи студентом Віденського університету, Шумпетер самостійно вивчив математику і праці економістів-математиків від О. Курно до К. Вікселя. I хоча тогочасна австрійська школа принципово заперечувала можливість і доцільність використання математики в економічному аналізі, Й. Шумпетер уперше серед учених в економічних дослідженнях використав математичні методи, i в рік захисту дисертації на звання доктора права (1906) в австрійському виданні "Zeitschrift fur Volkswirtschaft, Sozialpolitik und Verwaltung" (Bd. 15) опублікував статтю "Uber die mathematische Methode der theoretischen konomie" ("Про математичний метод у теоретичній економії") [21]. (Рис. 1)

Правильність висновку Шумпетера про

перспективність математичної економії підтвердиться життям, коли завдяки зусиллям вченого і його однодумців у $30-x$ роках XX ст. на основі поєднання економічної теорії, статистики i математики буде засновано Міжнародну економетричну спілку.

У наукових уподобаннях молодого юриста Шумпетера переважає інтерес до економічної теорії, і в 1908 p. у Лейпцигу виходить його перша велика теоретична праця "Das Wesen und der Hauptinhalt der theoretischen Nationalukonomie" ("Суть і головний зміст теоретичної політекономії") [24], в якій 25-річний автор на 626-ти сторінках дослідив походження, функціонування і занепад післямарксівської політекономії, познайомив наукову громадськість 3 теоретичними досягненнями школи маржиналістів тощо. Ця робота Шумпетера завдяки зусиллям його вчителя і покровителя БемБаверка була зарахована як друга дисертація (Habilitationschrift). (Рис.2)

І хоча книга була зустрінута досить прохолодно і скептично німецькими й австрійськими економістами, однак завдяки клопотанням того ж Бем-Баверка в 1909 році послужила підставою початку викладацько-наукової кар'єри молодого вченого у Чернівецькому імператорському i королівському імені Франца Йосифа університеті, де ще 3 моменту заснування у 1875 р. викладалася політекономія.

Тут на посаді позаштатного професора політичної економії факультету держави і права Й.А. Шумпетер працював до 1911 року.

За ці два неповні навчальні роки він, як єдиний викладач економіки, читав лекції $з$ усього кола 


\section{ÜBER DIE MATHEMATISCHE METHODE DER THEORETISCHEN ÖKONOMIE. \\ VON}

JOSEF SCHUMPETER.

1. Im Vorworte zur ersten Auflage seiner Principles of Science macht Jevons folgende Bemerkung: "Yet few will deny, that the methods of reasoning ought to be studied, especially by those, who endeavour to introduce scientific order into less successful and methodical branches of knowledge." Für kein Gebiet des Wissens gilt das vielleicht so sehr, als für das der theoretischen Ökonomie. In der Tat sehen wir, daß methodologische Fragen in der wissenschaftlichen ökonomischen Diskussion eine sehr große Rolle spielen. Nachdem die Grundsteine unserer Disziplin gelegt, ihre Hauptprobleme gestellt, ihre Begriffe eine zeitlang bearbeitet worden waren, mußte die Frage nach der Art des weiteren Vorgehens eine überragende Bedeutung gewinnen. Die dabei zutage tretenden Gegensätze sind - und waren noch viel mehr - bekanntlich sehr heftige; als die feindlichen Pole pflegt man die historische und die exakte Richtung zu bezeichnen. Aber auch innerhalb dieser beiden Lager kann man mehr oder minder bedeutende Differenzen wahrnehmen. Für di e exakte Theorie nun ist eine der interessantesten methodologischen Fragen die, ob die Anwendung mathematischer Denkformen hier möglich und wünschenswert, weiters, ob sie nötig sei. Diese Frage, die im folgenden kurz erörtert werden soll, ist wichtig. Wäre sie zu bejahen, so müßte man jeden Augenblick gewärtigen, auf Probleme zu stoßen, die $\mathrm{nur}$ mit dieser Methode zu lösen sein könnten; wenigstens spricht dafür die Analogie der bereits mathematischen Disziplinen.

Es liegt nahe, daß die wenigen Vertreter der mathematischen Ökonomie ihren Standpunkt auch prinzipiell entwickeln. Hauptsächlich haben das Cournot, Jevons und W a lras in den Einleitungen zu ihren Werken, $\mathrm{Edg}$ e worth und $\mathrm{Paret}{ }^{1}$ ) auch in besonderen Artikeln getan. An diese berufeneren Instanzen sei der Leser hier ein- für allemal gewiesen. Die

1) Edgeworth: Presidential Address to the Sect. F., Brit. Association 59 th meeting, dann Art. Math. Method in Palgraves Dictionary.

Pareto: Art. Mathem. Nationalökonomie in Bd. I, Heft 7 der math. Enzyklopädie.

Рис. 1. Перша сторінка статті Шумпетера "Uber die mathematische Methode der theoretischen ukonomie" (з архівів Наукової бібліотеки ЧНУ імені Юрія Федьковича) 


\title{
19672

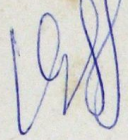

\section{Das Wesen und der Hauptinhalt}

der

\section{theoretischen Nationalökonomie.}

\author{
Von
}

Dr. Joseph Schumpeter.

है

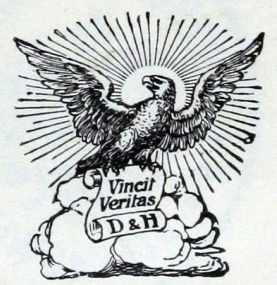

\section{HAYROB SISJIOTEKA}

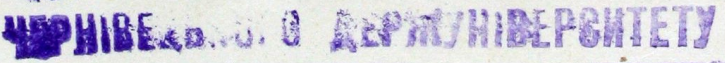

Leipzig,

Verlag von Duncker \& Humblot.

1908.

Рис. 2. Праця Шумпетера "Das Wesen und der Hauptinhalt der theoretischen Nationalukonomie" (з архівів Наукової бібліотеки ЧНУ імені Юрія Федьковича) 
Сторошук Б. Д., Дячук М. П.

економічних і суміжних соціологічних, політичних і юридичних питань, про що свідчить перелік курсів і семінарів, які викликали великий інтерес з боку студентів: "Австрійське фінансове право", "Аналіз Бем-Баверком економічних процесів", "Вправи 3 аналізу газетних повідомлень на економічні теми, особливо про процеси на ринку грошей", "Гроші, кредит і банки", "Народноекономічна політика", Національна економія", "Про соціальне страхування 3 особливим зважанням на його зв'язок $з$ торгівлею і фінансовою політикою", "Семінар 3 національної економії та фінансової науки", "Фінансова наука", "Фінансове право".

Працюючи в Чернівецькому університеті, Й. Шумпетер протягом 1910-1911 рр. написав свою другу велику працю - "Theorie der wirtschaftlichen Entwicklung" ("Теорія економічного розвитку") [18], опубліковану в Лейпцигу у 1912 році, коли вчений вже викладав у Граці. Саме це фундаментальне видання, яке також зберігається в іноземних фондах наукової бібліотеки, принесло 29-річному автору світову славу і визнання в галузі економічної теорії. (Рис. 3)

У цій праці Шумпетер першим з економістів спробував дати цілісну уяву про механізм функціонування та пояснити суть динаміки розвитку капіталістичної економіки. На противагу статичній (стаціонарній) економіці він намагався створити модель економіки, що розвивається. Як один із основних фундаторів концепції "підприємництво і нововведення", Шумпетер розглядає підприємця як новатора, що створює нові виробничі ситуації шляхом виробництва нового товару, використання у виробництві нової техніки або нового застосування наявних засобів виробництва, освоєння нових ринків збуту, відкриття нових джерел сировини, використання нової економічної організації виробництва. За Шумпетером підприємець - це лідер, головний суб'єкт економічної системи, рушійна сила науково-технічного розвитку.

Є в університетській бібліотеці і друге, значно допрацьоване автором, уже професором Боннського університету, видання цієї ж праці, а саме: "Theorie der wirtschaftlichen Entwicklung: Eine Untersuchung uber Unternehmergewinn, Kapital, Kredit, Zins und den Konjunkturzyklus" ("Teopiя економічного розвитку: дослідження підприємницького прибутку, капіталу, процента та циклу кон'юнктури") [19], яке в 1934 р. перекладено англійською мовою, а загалом в 3040-ві роки XX ст. також французькою, італійською, іспанською та японською мовами.

У написаній в Чернівцях "Теорії економічного розвитку" вперше сформульовані ідеї "утворюючої руйнації", "створення нових комбінацій" та інші, які пізніше Шумпетер розвинув у наступних своїх працях, що стали віхами в його творчій біографії.

Запропоновану в "Теоріі..." динамічну модель ечений едосконалив у виданій в Нью-Йорку праці "Економічні цикли" (1939) [8], яка містить теорію циклічних коливань, аналіз циклічного розвитку економіки - однієї з найважливіших характеристик ринкової економіки, пов'язуючи циклічність 3 новаторською діяльністю, а стимулом для новаторства називає підприємницький прибуток.

Шумпетер по праву вважається фундатором інноваційної теорії економічного розвитку на основі інвестицій, спрямованих у різні галузі економіки.

Викладені в уже вказаних працях думки вченого, його наукові концепції стали основою для розуміння основної ghfws Шумпетера "Капіталізм, соціалізм і демократія" (1942) [9], в якій зроблено широкі узагальнення щодо історичної долі капіталізму, його сучасного стану і викладено ідею трансформації в перспективі в нову форму соціалізм.

Й.А. Шумпетер одним із перших дослідив проблему методології і періодизації економічного аналізу у своїй найбільшій за обсягом видрукуваній уже після смерті вченого "Історії економічного аналізу" (1954) [13], яка і сьогодні залишається актуальною. Оволодівши ще під час навчання в Терезіанумі латинською, грецькою, італійською, англійською і французькою мовами, він на основі оригіналів розкрив історію економічної думки 3 часів Стародавньої Греції nf Риму до середини XX ст. А передували виданню "Історії економічного аналізу" написані вченим в його ранній період життя роботи "Економічний метод i доктрина: Історичний нарис" (1914) i, звичайно, "Теорія економічного розвитку".

Наукові дослідження Й. Шумпетера відображені, крім фундаментальних праць, у виданні понад 200 статей, навіть ранні з яких заслуговують великої уваги.

Зокрема, в іноземних фондах Наукової бібліотеки Чернівецького національного університету в 27-ми томах зберігається тогочасне видання "Zeitschrift f?r Volkswirtschaft, Sozialpolitik und Verwaltung" (перший том датується 1892 роком), в числі видавців якого були Eugen v. B?hm-Bawerk (Є. Бом-Баверк), Eugen Fhilippovich (С. Філіппович), Friedrich Freiherr v. Wieser (Ф. Візер). 3 цим виданням співпрацював i Шумпетер, поєднуючи роботу у виданні 3 викладацькою і науковою діяльністю в Чернівцях і Граці.

Тут, окрім багаточисленних рецензій, Й. Шумпетер публікує свої статті, у яких простежується вплив на шумпетерівську теорію економічного розвитку і високо оцінюються ідеї і погляди видатних економістів Джона Бейтса 


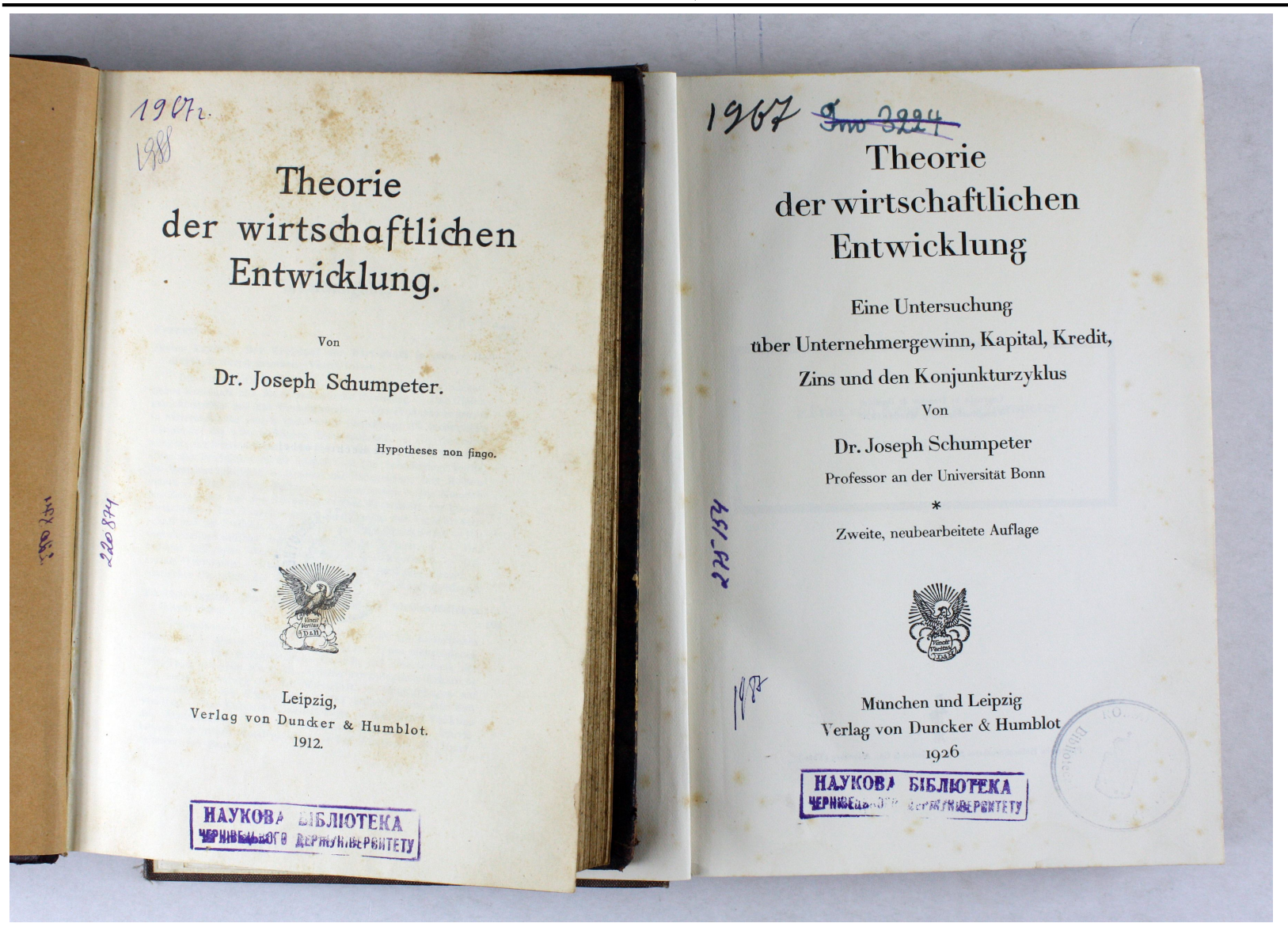

Рис. 3. Перше і друге видання праці Шумпетера "Theorie der wirtschaftlichen Entwicklung" (3 архівів Наукової бібліотеки ЧНУ імені Юрія Федьковича)

Кларка, Фрідріха Візера, Леона Вальраса та інших: "Professor Clarks Verteilungstheorie" ("Tеорія розподілу професора Кларка") - 1906 р. [15], "Bemerkungen uber das Zurechnungsproblem" ("Замітки про проблеми розподілу") - 1909 р. [7], "?ber das Wesen der Wirtschaftskrisen" ("Про стан економічної кризи") - 1910 р. [20], "Marie Esprit L?on Walras" ("Марі Еспрі Леон Вальрас") - 1910 p. [14], "Eine "dynamische" Theorie des Kapitalzinses. Eine Entgegnung" ("Динамічна теорія процентів капіталу. Заперечення") - 1913 p. [11], "Das wissenschaftliche Lebenswerk Eugen von B?hmBawerks" ("Науковий життєвий твір Євгена фон Бем-Баверка) - 1914 р. [26]. (Рис. 4)

Також у фонді зарубіжних видань НБ ЧНУ є 64-томне (за 1888-1930 pр.) видання "Archiv fur Soziale Gesetzgebung und Statistik" ( 31904 p. 19 том нова назва - "Archiv fur Sozialwissenschaft und Sozialpolitik"), у якому починаючи з 1917 року (44 том) до 1930 року (64 том), Йозеф Шумпетер поряд 3 такими відомими в науковому середовищі постатями як Вернер Зомбарт (Werner Sumbart), Макс Вебер (Max Weber), Альфред Вебер (Alfred Weber), Едгар Яфе (Edgar Jaffu), Еміль Ледерер (Emil Lederer), зазначений як один з видавців (упорядників). У вказаному виданні опубліковані статті вченого, в тому числі його ранні праці: "Die Wellenbewegung des Wirtschaftslebens" 1913 [23], "Das Grundprinzip der Verteilungstheorie" 1916-1917 [12], "Das Bodenmonopol" 1917-1918 [10], "Das Sozialprodukt und die Rechenpfennige" 1917-1918 [16] та інші.

Не тільки австрійські та німецькі видавництва Відню, Лейпцигу, Мюнхена друкували ранні праці Шумпетера. Приміром, у 1910 р. У Чернівцях серед доповідей і статей чернівецького соціальнонаукового товариства окремим виданням вийшла робота Й. Шумпетера "Wie studiert man Sozialwissenschaft" ("Як вивчати соціальну науку") [25], котра сьогодні, як частина національного надбання, зберігається у фондах відділу рідкісних та цінних книг бібліотеки. (рис. 5)

Серед наукових інтересів ученого чільне місце займали проблеми суспільного розвитку, концепції представників соціального напрямку в економічній науці і тому природно, що покидаючи в 1911 р. Чернівецький університет, Шумпетер прочитав знамениту лекцію "Vergangenheit und Zukunft de Sozialwissenschaften" ("Минуле і майбутнє соціальних наук") [22].

Безпосередньо перед Першою світовою війною було організовано обмін професорами, в 
Bemerkungen aber das Zurechnungsproblem.

$$
2 \text { Schumpeter. }
$$

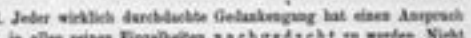

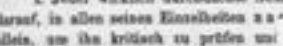

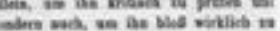

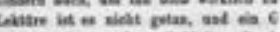

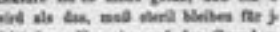
Steplens. Sar dies at des armet o

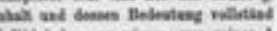

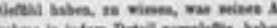

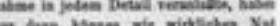

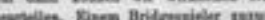

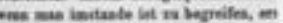

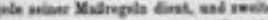

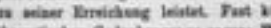

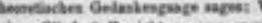

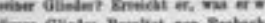

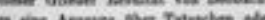

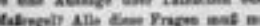

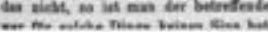

\section{Eine „dynamische“ Theorie des Kapitalzinses.}

Eine Entpegnung.

Voe dosef Schumpeter.

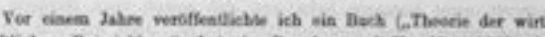

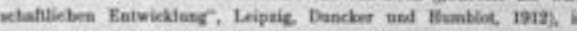

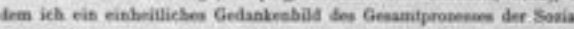

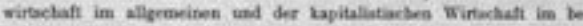

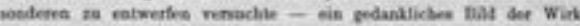

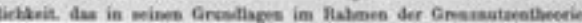

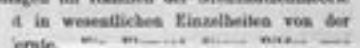

$$
\text { iente }
$$

PROFESSOR CLARKS VERTHILAXGSHEOEIE.

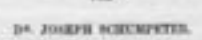

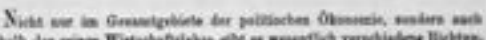

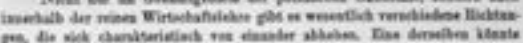

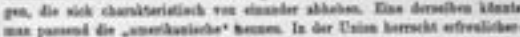

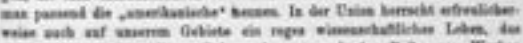

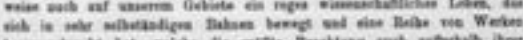

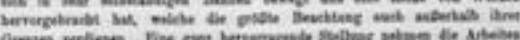

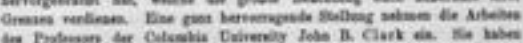

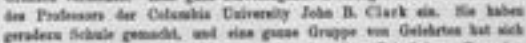

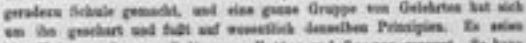

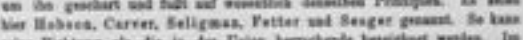

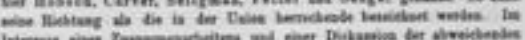

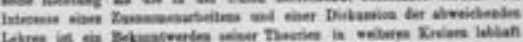

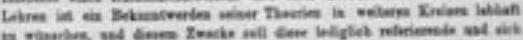

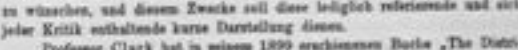

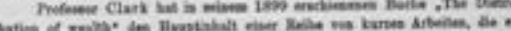

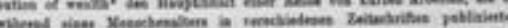

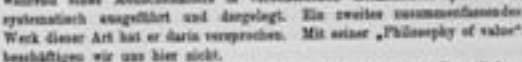

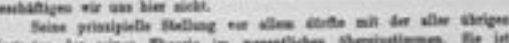

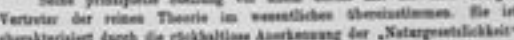

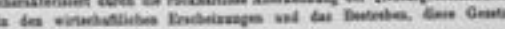

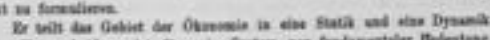

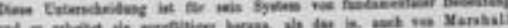

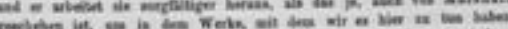

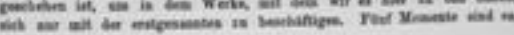

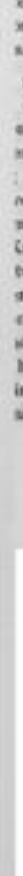
Intate ErNaruagogrued alin

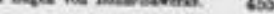

Manin, dem das
Marie Esprit Léon Walras †.

$$
\text { 4. Schumpeter. }
$$

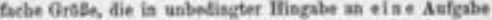

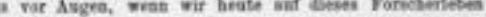

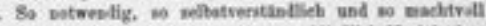

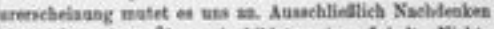
Wrme der reines Otossmie bildete seises Istalt. Nichts

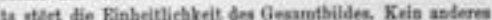

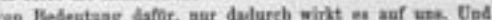

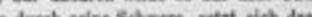
vamatnoght, gleichiar

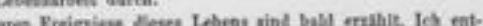

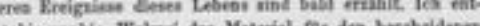

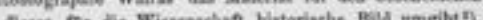

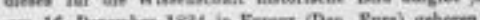

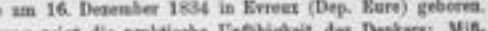

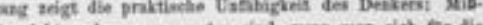

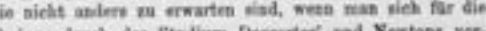

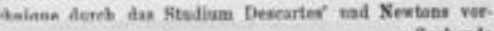
t Sachende in asteside carakiteria seis den hangurerof ihn die wh $n$ be rallen. vat gevidimet. Joset Schumpeter. es Wektes, imer Biet:

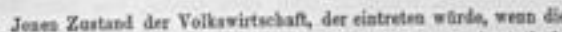

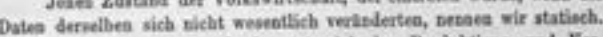

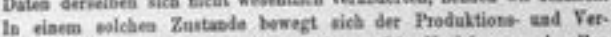

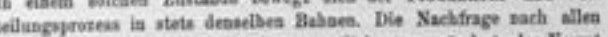

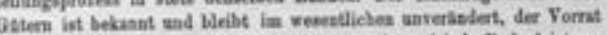

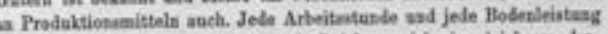

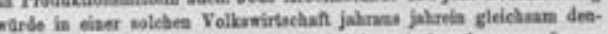

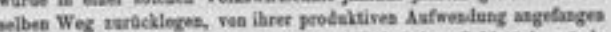

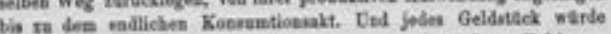

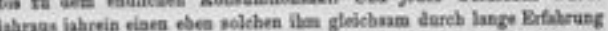

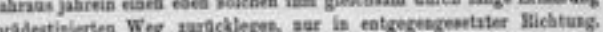

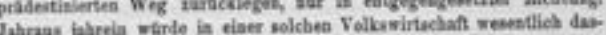

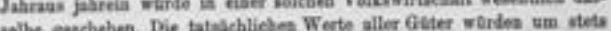

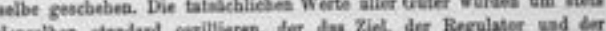

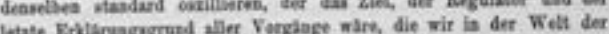

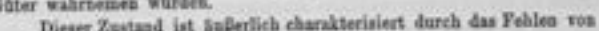

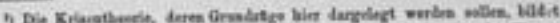

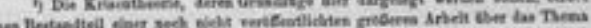

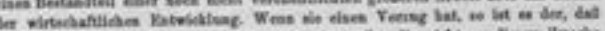

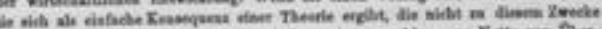

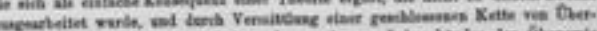

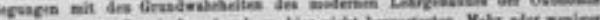

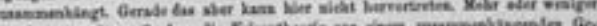

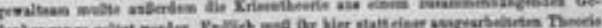

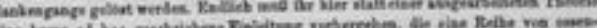

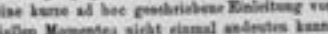

Рис. 4. Статті Шумпетера у періодичному виданні "Zeitschrift f?r Volkswirtschaft, Sozialpolitik und Verwaltung" (3 архівів Наукової бібліотеки ЧНУ імені Юрія Федьковича).

тому числі провідними світовими економістами, між американськими і європейськими університетами. I одним із перших, якщо не найпершим австрійцем, хто брав участь в цій програмі обміну, був Шумпетер, який у 1913 році відвідав Гарвард. Завдяки цьому у Відні в перші післявоєнні роки знали праці американських економістів-теоретиків.

Після викладацької роботи в Чернівцях і Граці Й. Шумпетер протягом семи місяців 1919-1920 pр. обіймав посаду міністра фінансів Австрійської республіки, потім до 1924 р. очолював невеликий приватний віденський банк, а, повернувшись до наукової діяльності, спочатку викладав у Японії, пізніше очолював кафедру державних фінансів економічного факультету в університеті Бонна, а 31932 р. і до кінця життя (1950) - викладав у Гарвардському університеті США, де 25 років очолював кафедру. В 1949 р. його як іноземця вперше обрали президентом Американської економічної асоціації [5, с. 89-93].

Уже після смерті вченого окрім геніальної "History of Economic Analysis" ("Iсторіï економічного аналізу") 1954 [13] побачила світ його праця "Ten Great Economists" ("Десять найвидатніших економістів") 1951 [17], упорядковане дружиною, також відомим 


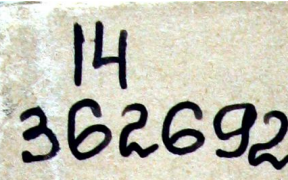

VORTRAEGE UND ABHANDLUNGEN

herausgegeben vom Sozialwissenschaftlichen akademischen Vereine IN CZERNOWITZ.

Nr. 2.

Wie studiert man Sozialwissenschät:

VON

UNIV.-PROF. Dr. JOSEF SCHUMPETER:

000

PREIS 50 HELLER.

CZERNOWITZ, 1910.

IM KOMMISSIONSVERLAG DER K. K. UNI-

VERSITÄTSBUCHHANDLUNG H. PARDINI.

O

BUCHDRUCKEREI M. EBNER.

Рис. 5. Праця Шумпетера " Wie studiert man Sozialwissenschaft " (3 архівів Наукової бібліотеки ЧНУ імені Юрія Федьковича) 
Сторошук Б. Д., Дячук М. П.

економістом, видання праць Йозефа Шумпетера.

Й.А. Шумпетера по праву вважають генієм економіки. Видатний учений свого часу Йозеф Шумпетер зумів не тільки проаналізувати і поглибити вже існуючі теорії, але й сформулювати власні, незалежні від оточення, економічні ідеї. Його твердження часто були викликом вже існуючій економічній школі, а зроблені ним висновки зберігають свою актуальність і сьогодні.

Теоретичні розробки Шумпетера, які $\epsilon$ надбанням світової економічної думки, стали відправною точкою формування поглядів сучасних економістів на проблеми регулювання ринкової економіки.

А формування поглядів самого Й.А. Шумпетера, становлення його як ученого, визначення майбутніх напрямків досліджень і наукових пріоритетів відбувалось в ранній період наукової кар'єри вченого, і в тому числі, в роки викладання в Чернівецькому університеті.

Адже Йозеф сам вважав, що світогляд людини формується до тридцяти років, а на решту частину життя припадає вдосконалення раніше сформованих поглядів.

Майже через 20 років після смерті вченого, німецький професор Е. Шнайдер сказав: "Йозеф Алоїз Шумпетер належить до небагатьох істинно великих представників економічних і суспільних наук в цьому столітті. Можливо, він був останнім 3 тих, хто впевненим поглядом майстра охоплює всю сферу економічних і суспільних наук і міг розуміти суспільство й економіку в їх взаємовідносинах і зв'язках, в їх історичній, аналітичній і філософській перспективі... Майбутні покоління повинні знати, що за людина він був" [6, c. 7].

\section{Список літератури}

1. Йозеф Шумпетер та проблеми реформування економіки України / Відп. ред.: Зайцев Ю.К., Фініков Т.В. - К.: Таксон, 2000. - 243 с.

2. Науковий вісник Чернівецького університету: Збірник наукових праць. Серія: економічна. - Чернівці: ЧДУ, 1998. - Вип. 25. - 182 с.

3. Социально-политические воззрения И. Шумпетера: Реф. сб. / Редкол.: Л.Б. Волков и др. - М.: ИНИОН, 1989. - 105 с.

4. Творча спадщина Йозефа А. Шумпетера та трансформація сучасної економіки України: Матеріали міжнародної науково-практичної конференції (Чернівці, 23 квітня 2003 року) / Редкол.: I.Ф. Комарницький (наук. ред.) та ін.; Чернівецький національний університет імені Юрія Федьковича, Економічний факультет, Буковинський центр економічної освіти та підприємництва, Інститут регіональних досліджень та ін. - Чернівці: Рута, 2003. -367 c.

5. Recktenwald H.C. Schumpeters monumentales
Werk - Wegweiser fur eine dynamische Analyse / H.C. Recktenwald, F.M. Scherer, W.F. Stolper. - Dusseldorf: Wirtschaft u. Finanzen, 1988. - $110 \mathrm{~s}$.

6. Schneider E. Joseph A. Schumpeter - Leben und Werk eines grossen Sozialukonomen. - T?bingen, 1970. $-98 \mathrm{p}$.

7. Schumpeter J. Bemerkungen uber das Zurechnungsproblem // Zeitschrift fur Volkswirtschaft, Sozialpolitik und Verwaltung: Organ der Gesellschaft usterreichischer Volkswirte. Bd. 18 / Hrsg. E. v. B?hmBawerk u. a. - Wien; Leipzig: Braumuller, 1909. - S. 79132.

8. Schumpeter J. Business Cycles: A Theoretical, Historical and Statistical Analysis of the Capitalist Process. - New-York; London: Mc Graw-Hill, 1939. - Wol. $1-2$.

9. Schumpeter J. Capitalism, Socialism and Democracy. - New-York: Harper, 1942. - XIV. - 431 p.

10. Schumpeter J. Das Bodenmonopol. Eine Entgegnung auf Dr. Oppenheimers Artikel // Archiv fur Sozialwissenschaft und Sozialpolitik. Bd. 44 / Hrsg. v. E. Jaffe, W. Sombart, M. Weber u. J. Schumpeter. T?bingen: J. C. B. Mohr (Paul Siebeck), 1917-1918. - S. 495-502.

11. Schumpeter J. Eine "dynamische" Theorie des Kapitalzinses. Eine Entgegnung // Zeitschrift fur Volkswirtschaft, Sozialpolitik und Verwaltung: Organ der Gesellschaft osterreichischer Volkswirte. Bd. 22 / Hrsg. E. v. Bohm-Bawerk u. a. - Wien: Manz, 1913. - S. 599-656.

12. Schumpeter J. Das Grundprinzip der Verteilungstheorie// Archiv fur Sozialwissenschaft und Sozialpolitik. Bd. 42 / Hrsg. v. E. Jaffe, W. Sombart, M. Weber.- Tubingen: J. C. B. Mohr (Paul Siebeck), 19161917. - S. 1-88.

13. Schumpeter J. History of Economic Analisis / Hrsg. v. E.B. Schumpeter. - New-York: Oxford University Press, 1954. - XIV, $1260 \mathrm{p}$

14. Schumpeter J. Narie Esprit Leon Walras // Zeitschrift fur Volkswirtschaft, Sozialpolitik und Verwaltung: Organ der Gesellschaft osterreichischer Volkswirte. Bd. 19/ Hrsg. E. v. Bohm-Bawerk u. a. - Wien; Leipzig: Braum?ller, 1910. - S. 397-402.

15. Schumpeter J. Professor Clarks Verteilungstheorie // Zeitschrift fur Volkswirtschaft, Sozialpolitik und Verwaltung: Organ der Gesellschaft osterreichischer Volkswirte. Bd. 15 / Hrsg. E. v. Bohm-Bawerk u. a. - Wien; Leipzig: Braumuller, 1906. - S. 325-333.

16. Schumpeter J. Das Sozialprodukt und die Rechenpfennige. Glossen und Beitr?ge zur Geldtheorie von heute // Archiv fur Sozialwissenschaft und Sozialpolitik. Bd. 44 / Hrsg. v. E. Jaffe, W. Sombart, M. Weber u. J. Schumpeter. - Tubingen: J. C. B. Mohr (Paul Siebeck), 1917-1918. - S. 627-715.

17. Schumpeter J. Ten Great Economists - From Marx to Keynes. - New-York: Oxford University Press, 1951. $\mathrm{XIV}, 305 \mathrm{p}$.

18. Schumpeter J. Theorie der Wirtschaftlichen Entwicklung. - Leipzig: Duncker u. Humblot, 1912. - VIII, $548 \mathrm{~s}$.

19. Schumpeter J. Theorie der Wirtschaftlichen Entwicklung: Eine Untersuchung ?ber Unternehmergewinn, Kapital, Kredit, Zins und den Konjunkturzyklus. Zweite, neubearb. Auflage. - 
Munchen; Leipzig: Duncker u. Humblot, 1926. - XIV, $370 \mathrm{~s}$.

20. Schumpeter J. Uber das Wesen der Wirtschaftskrisen // Zeitschrift fur Volkswirtschaft, Sozialpolitik und Verwaltung: Organ der Gesellschaft osterreichischer Volkswirte. Bd. 19 / Hrsg. E. v. BohmBawerk u. a. - Wien; Leipzig: Braum?ller, 1910. - S. 271325.

21. Schumpeter J. Uber die mathematische Methode die theoretischen "okonomie" // Zeitschrift f?r Volkswirtschaft, Sozialpolitik und Verwaltung: Organ der Gesellschaft osterreichischer Volkswirte. Bd. 15 / Hrsg. E. v. B?hm-Bawerk u. a. - Wien; Leipzig: Braumuller, 1906. - S. 30-49.

22. Schumpeter J. Vergangenheit und Zukunft der Sozialwissenschaften: Schriften des Sozialwissenschaftlichen Akademischen Vereins in
Czernowitz. Heft 7. - M?nchen; Leipzig, 1915.

23. Schumpeter J. Die Wellenbewegung des Wirtschaftslebens // Archiv fur Sozialwissenschaft und Sozialpolitik. Bd. 39 / Hrsg. v. E. Jaffe, W. Sombart, M. Weber u. J. Schumpeter. - Tubingen: J. C. B. Mohr (Paul Siebeck), 1915. - S. 1-32.

24. Schumpeter J. Das Wesen und der Hauptinhalt der theoretischen Nationalokonomie. - Leipzig: Duncker u. Humblot, 1908. - XII, $626 \mathrm{~s}$.

25. Schumpeter J. Wie studiert man Sozialwissenschaft. Wortraege und Abhandlungen: Schriften des Sozialwiessenschaftlichen Akademischen Vereins in Czernowitz. Heft 2. - Czernowitz, 1910. - XI, 28 s.

26. Schumpeter J. Das wissenschaftliche Lebenswerk Eugen von Bohm-Bawerk // Zeitschrift f?r Volkswirtschaft, Sozialpolitik und Verwaltung: Organ der Gesellschaft osterreichischer Volkswirte. Bd. 23 / Hrsg. E. v. B?hm-Bawerk u. a. - Wien: Manz, 1914. - S. 454-528.

Аннотация

Богдан Сторощук, Мария Дячук

\section{ЙОЗЕФ АЛОИЗ ШУМПЕТЕР И ЧЕРНОВИЦКИЙ УНИВЕРСИТЕТ}

Рассматриваются научные достижения выдающегося ученого-экономиста Йозефа Алоиза Шумпетера в контексте его научно-педагогической работе в начале XX в. в Черновичком университете. На основе богатого архива Научной библиотеки Черновиџкого наџионального университета имени Юрия Федьковича анализируются условия формирования $и$ закономерности эволючии взглядов ученого на основные проблемы политической экономии в контексте сочиально-экономических условий Австро-Венгрии и научных сред исторической школы и маржинализма в первых десятилетиях $X X$ в.

Ключевые слова: Йозеф Алоиз Шумпетер, Черновицкий университет, политическая экономия.

\section{Summary}

Bogdan Storoschuk, Maria Dyachuk

\section{JOSEF ALOIS SCHUMPETER AND CHERNIVTSI UNIVERSITY.}

Considers the scientific achievements of outstanding economist Joseph Alois Schumpeter in the context of his scientific and pedagogical work in the early twentieth century. at Chernivtsi University. Based on a rich archive of Scientific Library of National University of Chernivtsi Yuriy Fedkovych analyzes the conditions for the formation and evolution of patterns of scientific views on major issues of political economy in the context of socio-economic conditions of Austria-Hungary and the scientific community and the historical school marginalism in the first decades of the twentieth century.

Keywords: Joseph Alois Schumpeter, Chernivtsi University, Political Economy. 
УДК 330.341.1

СБілоцерківець В.В., 2011

Національна металургійна академія України, м. Дніпропетровськ

\title{
КРИТЕРІЇ ВИЗНАЧЕННЯ НОВОЇ ЕКОНОМІКИ: ТЕХНОЛОГІЧНИЙ АCПЕКТ
}

\begin{abstract}
Пропонується синтетичний підхід до визначення нової економіки, за якого існуючи дефініиії виступають як локальні визначення окремих проявів иілісного явища. Виявлено основні критеріі членування нової економіки в технологічному ракурсі. Доведена різомно-холістична сутність неоекономіки та необхідність застосування для ї̈ дослідження модельного холістичного niдxоду.
\end{abstract}

Ключові слова: необлаго, нова економіка, технологічний критерій, різоми, холістичний підхід.

Постановка проблеми. Останні десятиліття наукового дискурсу в економічній теорії позначені надзвичайною увагою до нових явищ в економічному житті, явищ, які в найбільш загальному вигляді окреслюються терміном "нова економіка". Проте змістова дефініція нової економіки як цілісності й досі залишається поза межами наукового дослідження, вчені фактично обмежуються констатацією низки ознак сучасної авангардної економіки. Отже виникає проблема отримання більш чіткого визначення цього відносно нового явища, формулювання адекватних критеріїв розрізнення ново економічного в просторі економічного.

Аналіз останніх досліджень і публікацій. Величезна кількість науковців, а поміж них такі знані, як Валдайцев С.В., Ігнацька М.A, Мясникова Л.А., Стрелец І.А. [1-4], присвячують даній проблеми свої статті та монографії, постійно точаться дискусії щодо специфічних проблем, пов'язаних 3 виникненням i розвитком новоекономічного життя. Причому найбільш поширеним у науковому середовищі є сприйняття неоекономіки як тотожної за змістом високотехнологічній економіці. Насправді ж таке розуміння зовсім не наближає до розкриття наукового змісту словосполучення "нова економіка", оскільки критеріальні ознаки високотехнологічної економіки залишаються в остаточному підсумку фактично не з'ясованими. Відповідно до критерію високотехнологічності віднести до нової економіки можна навіть економіку Другої технологічної революції початку XX ст.[5]. Масована поява нових технологій, їх широке розповсюдження в ті часи не залишає сумніву в адекватності сприйняття такої економіки як відносно нової, якісно відмітної від економіки Першої технологічної революції.

Не розв'язані раніше частини загальної проблеми. Розуміння нової економіки як економіки, неподібної до старої, домінантної в даний період, страждає низкою недоліків. Така нова економіка
3 плином часу набуватиме все більшої ваги, а отже перебиратиме на себе статус домінантної, консервуючись і перетворюючись змістово на нову "стару". Отже, виникає необхідність пошуку чітких критеріїв визначення сутності нової економіки, зокрема, в технологічному аспекті.

Формулювання цілей статті. Мета статті виявлення основних критеріїв членування нової економіки, визначення змістовних субмножин в неоекономічній цілісності, їх ознаки та групування

Викладення основного матеріалу дослідження. Свого часу кочівницька економіка була новою стосовно економіки збиральництва, а аграрна стосовно кочівницькою тощо. Отже, сучасний варіант нової економіки теж в майбутньому поступиться місцем іншій, ставши в процесі трансформації старою. Уже нові, невідомі нам технології окреслять контури наступної, знов лише тимчасово модернової економіки, будуть визначати обличчя нової економіки майбутнього.

Спирання в дефінітивному плані на перманентно мінливі критерії, на наш погляд, недостатньо продуктивне і не дозволяє розкрити сутність та зміст явища нова економіка. Розпливчастість та нестійкість об'єкта дослідження, а, відповідно, й нечіткість предмета, його досить аморфний характер установлюють непереборні перешкоди на шляху проведення справді наукового дослідження. Отже, першочергове завдання - визначення не просто об'єкта дослідження на декларативному рівні, формальна фіксація в якості такого нової економіки, а з'ясування його змістового наповнення, побудова системи критеріїв, що мають забезпечити проведення чіткої демаркаційної лінії між явищами "новоекономічної" та "староекономічної" природи.

Ізольована фіксація одних форм і виключення 3 поля дослідження інших спричинює до формування вкрай спотвореного образу нової економіки, фрагментизує цілісний предмет 
дослідження. Науковий дискурс щодо сутності нової економіки, визначення ії кордонів за умови ототожнення неоекономіки з її окремими формами, штучного обмеження предмета нової економіки заздалегідь приречений на невдачу. Фактично ж усі спроби зрозуміти сутність нової економіки насправді демонструють спрямованість на з'ясування сутності й основних ознак найбільш сучасних форм їі прояву. Отже, розуміння неоекономіки як цілісності можливе лише на консолідуючій платформі, що передбачає зміщення акцентів в дослідженні від окремого на користь загального. Тоді на дефінітивному рівні неоекономіка виступить як імплозія зазначених визначень. Не відмовляючи, з одного боку, в праві на існування локальним дефініціям, такий підхід, 3 іншого боку, постулює їх єдність і комплементарність у межах цілісного сприйняття явища.

Справді, локальні визначення фіксують лише існування окремих різосом у межах різомної цілісності. Іманентна неоекономіці як різомному утворенню відсутність певної структурованості, необов'язковість наявності генетичних взаємозв'язків як між субцілісностями, так і між ïx складовими елементами, надзвичайна анклавізація, поширення відносно тривких дифузійних змичок старого та нового тощо вкрай ускладнюють розуміння такого утворення як цілісного. Взаємопереходи та взаємоперетворення елементів ще більш утруднюють його сприйняття. Натомість неоекономічні різосоми являють собою досить стабільні об'єднання множин, розвиток яких можна простежити, визначити особливості їх еволюції в межах певного топосу та хроносу. Застосування модельного холістичного підходу, за умов відсутності внутрішньої структурованості різосоми не завадить синтетичному створенню та подальшому розгляду екзоскелету цього органоїду. Перцепція такого екзоскелету на віртуально-експліцитному рівні зовсім не детермінує його фактичну матеріалізацію, але постійність сприйняття такого реально неіснуючого легітимізує його та відкриває широкі перспективи стосовно наступного оперування цим поняттям.

Можливість виокремлення в межах цілісності різосомних утворень дозволяє відобразити неоекономіку як множину таких утворень, що знаходяться в постійній взаємодії, взаємоперетворенні та перетіканні. Такі утворення неоднорідніми навіть на рівні потенціальності, оскільки містятьь неоекономічні елементи, що в межах автопоетичної системи мають бути віднесені до різних щаблів пагорбів складності. Скелетизація різосом виключає представлення їх як гомогенних, пласких множин. Справді, введення певного елемента до складу різосоми передбачає його ідентифікацію як їі члена, а отже, відповідність його за певним атрибутом саме означеній різосомі. Ідентичність усіх елементів органоїда за окремою ознакою гомогенезує таке утворення, але, з іншого боку, поліатрибутивність кожного з елементів, наявність цілого ряду інших властивостей, їх відмітності, часом, аж до незводимості, гетерогенезує різосому. I саме ця різнорідність елементів забезпечує подальшу структуризацію різомних органоїдов.

Водночас, безперечно гетерогенний характер новоекономічних різосом, поліатрибутивність їх елементів генерують нову проблему. Кожна різосома об'єднує елементи, у яких лише одна властивість із усього їх набору ідентична для всіх, але всі інші властивості як за притаманністю, так і змістово не обов'язково мають збігатися. Отже, в межах різомної цілісності потенційно можна виділити стільки наборів різосом, скільки властивостей притаманно окремим елементам різоми. Чим більш розповсюджена та багатоваріантна певна властивість, тим більше різосом буде входити до складу цілісності.

Існування численних варіантів різосомного членування цілісності належить трактувати, 3 одного боку, як перевагу, оскільки виокремлення множин за альтернативними критеріями надає можливість дослідження квазіструктурованих утворень у різних ракурсах, сприяє багатоаспектному сприйняттю нової економіки як холістичного явища. Такий розгляд адекватно відповідає розумінню неоекономіки на дефінітивному рівні як імплозії існуючих визначень, що має знизити гостроту наукового дискурсу щодо меж застосування цього терміна. 3 іншого боку, фактична безкінечність альтернативних варіантів утворення псевдоструктур безмежно розширює поле досліджень, породжуючи в межах холістичної програми необхідність вивчення всіх потенційно можливих різосом. Отже, такий поділ вкрай ускладнює подальше дослідження, заздалегідь створюючи передумови для критики його апріорно надзвичайної громіздкості. Втім, попередньо проголошена відмова від методу холізму як тотальності на користь модельного холістичного підходу достеменно вимагає скасування всеосяжного розгляду всіх можливо існуючих різомних органоїдів.

Відмова від формування та подальшого вивчення всіх можливих наборів різосом ще не означає виключення із переліку атрибутивних критеріїв поділу всіх, крім одного, обраного за певним принципом дослідником. Тому виникає необхідність виділення комплекту критеріїв розмежування неоекономічних різосом у 
Білочерківециь В. В.

загальному атрибутивному наборі. Зрозуміло, що введення окремих критеріїв до цього комплекту теж передбачає досить суб'єктивну за змістом процедуру їх вибору 3 існуючого набору. Натомість наявність кількох критеріїв, а отже, i кількох наборів різосом має значно послабити такий суб'єктивізм, забезпечити рух у напрямку підвищення рівня об'єктивності пізнання неоекономіки. За якими же саме критеріями має відбуватися таке розмежування?

На наш погляд, найбільш прийнятними будуть критерії, що були вже закладені, хоч і в дещо неявній формі, але активно застосовувалися в межах попередніх досліджень явищ неоекономічної природи та одночасно враховують консумаційний та виробничій аспекти нової економіки. Отже, до складу критеріального комплекту, в першу чергу, в межах виробничої площини мають увійти технологічний та продуктово-технологічний.

Використання технологічного критерію дозволить детермінувати множину різосом, які об'єднують неоекономічні елементи, що у своїй цілісності забезпечують існування певної технологіï, iї реалізацію на продуктовому зрізі та на рівні задоволення потреб. Спорідненість окремих технологій, з одного боку, та необхідність їх комплементарного застосування 3 метою отримання конкретних товарів і послуг, з іншого, встановлює обмеження щодо ступеня суверенізації різосом, роблячи самостійне функціонування окремого органоїда вкрай маловірогідними, та надає статус імперативного співробітництву між ними як запоруці порівняно тривалого життя даного товару та його подальшого розвитку. Більше того, така взаємодія в межах об'єднаних за певною ознакою чи їх набору різомних утворень поступово поглиблюється та розширюється по мірі появи нових інваріантів продуктів, їх модифікації та диференціації. Продуктово-технологічний дрейф, генезис нових технологій за класичною схемою та їх становлення в межах процедури детериторізації-ретериторізації призводять до збільшення ареалу дії конкретних різосом співмірно зі зростаючою продуктовою популяцією. Природно, що це логічно вимагає формування коаліцій різосом, що завдяки співпраці між собою створюють передумови виникнення макротехнологій.

Менш усеосяжна взаємодія характерна для альянсів таких різосомних коаліцій, які утворюються вже на рівні технологічних укладів. Причому така взаємодія не набуває уніфікованого характеру, а позначена своєю історично визначеною специфікою. Це дозволяє визначити щонайменше шість різосомних альянсів, на порядок більше коаліцій та численні окремі різосоми, що входять до їх складу.

Розподіл різосом за альянсами не $\epsilon$ однорідним. Розвиток окремої технології не може відбуватися нескінченно, поступово він загальмовується та припиняється. Припинення розвитку, відсутність технологічних змін відобразиться й на оновленні продуктового ряду, а отже призведе до втрати елементами даної різосоми статусу неоекономічних. Аналогічні процеси відбуваються на рівні макротехнологічних коаліцій та їх альянсів. Зупинення розвитку на рівні альянсу може привести до повного виключення даного технологічного укладу з неоекономічного загалу.

Дискретизація в розподілі різосом за коаліціями та альянсами дуже спрощена та схематична. Насправді окремі різосоми можуть одночасно брати участь у кількох коаліціях, забезпечуючи існування зразу цілої низки змістовно неоекономічних макротехнологій. Більше того, коаліції, членом яких $є$ дана різосома, не обов'язково повинні входити лише до одного альянсу, оскільки виготовлення кінцевого продукту в розрізі певного технологічного укладу передбачає застосування не тільки технологічних прийомів, що унікально властиві саме цьому укладові. Тобто відбувається інфільтрація альянсів на рівні коаліцій іншоальянсовими різосомами. Проте зазначені введення не призводять до еклектизації альянсу та не піддають сумніву його новоекономічний статус, такі інфільтрати органічно поєднуються 3 іншими його складовими, утворюючи неоекономічну субцілісність. Не в меншій мірі подібна інфільтрація характерна для коаліцій, де вона здійснюється шляхом входження до них іншокоаліційних неоекономічних елементів в межах різосомних утворень. У цьому ракурсі дискретність різосом, їх коаліцій та альянсів набуває досить примарного вигляду. Стосовно безпосередньо неоекономічних різосом така розпливчастість досить обмежена, іiі елементи об'єднуються в множину відповідно до чітких ознак в межах існування певної технології і при всій поліатрибутивності таких елементів їх інкорпорація до інших різосом $\epsilon$ скоріше виключенням, аніж правилом. Області ж поширення різних коаліцій фактично виявляються взаємно перекриваючими, а ареали їх розповсюдження.

Висновки та перспективи подальших досліджень. Результатом дослідження стало виявлення основних критеріїв членування нової економіки, зокрема, технологічний та продуктовотехнологічний. Використання технологічного критерію дозволило визначити множину різосом, які об'єднують неоекономічні елементи, що в своїй 
цілісності забезпечують існування певної технологіï, іiі реалізацію на продуктовому зрізі та на рівні задоволення потреб. Виявлено існування за технологічним критерієм у межах неоекономіки шість різосомних альянсів, на порядок більше коаліцій та численні окремі різосоми, що входять до їх складу. Подальше дослідження має розкрити історичні передумови формуванні конкретних технологічних альянсів нової економіки, особливості національних економік, що зумовлюють прискорення та гальмування їх становлення.

\section{Список літератури}

1.Стрелец И.А. Новая экономика и информационные технологии /И.А. Стрелец. -М.: Экзамен, 2003. - С.13.

2. Мясникова Л.А. Экономика постмодернизма и отношения собственности / Л.А. Мясникова // Вопросы философии. - 2002. №7. -С.7.

3. Валдайцев С.В. Новые контуры экономики XXI века / С.В. Валдайцев // Вестник СанктПетербургского университета. - Серия 5. - 2001. - Вып. 3. - С.5-7.

4. Игнацкая М.A. Структурнофункциональный анализ новой экономики /М.A. Игнацкая. - М.: Изд-во РУДН, 2002. - 428 с.

5. Madsen J.B., Davis E.P. Equity Prices, Productivity Growth, and the 'New Economy' / J.B. Madsen, E.P. Davis // EPRU Working Paper Series. - Economic Policy Research Unit Institute of Economics University of Copenhagen. - 2004. - P. 34.

\title{
КРИТЕРИИ ОПРЕДЕЛЕНИЯ НОВОЙ ЭКОНОМИКИ: ТЕХНОЛОГИЧЕСКИЙ АСПЕКТ
}

\begin{abstract}
Предлагается синтетический подход к определению новой экономики, в соответствии с которым сущзествующчие дефиниции выступают локальными определениями отдельных проявлений иелостного явления. Выявлены основные критерии деления новой экономики в технологическом ракурсе. Доказана ризомно-холистичная сущцность неоэкономики и необходимость использования для ее исследования модельного холистичного подхода.

Ключевые слова: необлаго, новая экономика, технологический критерий, ризомы, холистичный подход.
\end{abstract}

\section{Summary}

Wolodymir Bilotserkivets

\section{CRITERIA FOR DETERMINING THE NEW ECONOMY:TECHNOLOGICAL ASPECTS}

Proposes a synthetic approach to defining the New Economy, according to which the existing definitions are the local definitions of individual manifestations of a holistic phenomenon. Shown basic criteria for the division of the New Economy of the Technological perspective. Proved the essence of Neoeconomics as the phenomenon of rhizome and holistic.

Key words: Neogood, New Economy, the Technological Criterion, Rhizomes, Holistic Approach. 


\title{
ФIНАНСИ
}

\author{
УДК $336.714+336.76$ \\ (C) Науменкова С.В., Перконос П. П., 2011 \\ Киӥвський національний університет імені Тараса Шевченка, м. Київ
}

\section{ЕВОЛЮЦІЯ ТЕОРЕТИЧНИХ ПІДХОДІВ ДО РОЗКРИТТЯ ЗМІСТУ ТА РОЛІ ФІНАНСОВОГО ПОСЕРЕДНИЦТВА}

Розглянено особливості діяльності фінансових посередників в сучасних умовах. Наведено еволючію теоретичних підходів до розкриття змісту та ролі фінансового посередництва. Розкрито поняття прийнятності фінансової послуги. Уточнено роль фінансових посередників у процесі надання фінансових послуг клієнтам на основі реалізації принципів прийнятності.

Ключові слова: фінансові посередники, фінансовий ринок, фінансова послуга, прийнятність фінансової послуги.

Вступ. Фінансовий ринок - необхідна складова ефективного функціонування економічної системи будь-якої розвиненої країни. Розвиток реального сектора економіки нерозривно пов'язаний 3 діяльністю учасників фінансового ринку, що опосередковують відносини між різними економічними суб'єктами. Саме діяльність фінансових посередників спрямована на виконання відповідних операцій з фінансовими активами для задоволення індивідуальних фінансових потреб кліснтів. Вони сприяють підвищенню ефективності використання фінансових ресурсів економічними суб'єктами через створення дієвих механізмів перерозподілу грошових коштів.

Аналіз останніх досліджень і публікацій. Вітчизняна та зарубіжна література вже увібрала значний досвід вивчення проблеми фінансового посередництва, ролі фінансових посередників на фінансовому ринку та їх значення для розвитку реального сектору економіки. Зокрема, формування теорії фінансового посередництва пов'язують 3 працями таких зарубіжних науковців, як Д.Акерлоф, Д.Бенстон, Р.Голдсміт, Д.Даймонд, Р.Левін, А.Пігу, К.Сміт, М.Спенс,Й.Шумпетер. Серед вітчизняних дослідників, що працювали над цією тематикою, можна виділити: О.Бала, Є.Бобров, С.Герасимова, В.Корнєєв, В.Міщенко, М.Савлук, В.Федоренко.

Постановка завдання. Зростання ролі фінансового сектора в забезпеченні ефективного функціонування економічної системи обумовлює необхідність формування чіткого розуміння ролі фінансового посередництва та діяльності фінансових посередників як основних учасників фінансового ринку. Це визначає необхідність виокремлення тих ключових ознак, що характеризують діяльність фінансових посередників в умовах подальшого розвитку ринку фінансових послуг.

Викладення основного матеріалу. На сьогодні роль інституту фінансового посередництва в розвитку економіки будь-якої країни важко переоцінити. Це $\epsilon$ результатом досить тривалого періоду формування та модифікації діяльності фінансових посередників.

Історично фінансове посередництва бере свої витоки з моменту розподілу праці у сфері обслуговування кругообігу фінансових активів як еквівалента товарних продуктів. Поступово цей вид діяльності почав виокремлюватись у самостійний вид бізнесу. Оскільки сприяння розвитку будь-яких структур, запозичення чи залучення капіталу потребує спеціальних знань, послуги фінансових посередників об'єктивно викликаються практикою.

Саме фінансові посередники виступають тими суб'єктами, які забезпечують зростання ефективності взаємодії між іншими елементами економічної системи. Це виявляється у створенні дієвих механізмів, спрямованих на формування цілісного за функціональною спрямованістю фінансового ринку, та на оптимізацію руху 
фінансових ресурсів, 3 метою забезпечення стійкого економічного розвитку країни.

За таких умов 3 розвитком і ускладненням економічних взаємозв'язків, виникненням нових форм задоволення потреб економічних суб'єктів розширювалася і роль фінансових посередників у забезпеченні економічного зростання. У більш класичному на сьогодні розумінні діяльність фінансових посередників почала формуватися 3 другої половини ХХ століття. Передумовами для цього стали:

- зміни в системі міжнародного кредитування, зумовлені розширенням діяльності THK;

- зниження дохідності операцій з фінансовими інструментами внаслідок високої інфляції;

- збільшення обсягів інвестицій у товарні активи;

- лібералізація банківської сфери;

- диверсифікація ринку корпоративних цінних паперів у зв'язку 3 початком масштабних структурних перетворень, активізацією процесів, пов'язаних зі злиттям, поглинанням, появою нових компаній;

- модернізація біржової та позабіржової торгівлі;

- запровадження новітніх технологій та інструментів;

- подальша концентрація фінансовопромислового капіталу, глобалізація фінансових потоків;

- зростання обсягів фінансових ринків та їх подальша інтернаціоналізація;

- перегулювання фінансових ринків;

- подальший розвиток міжнародної фінансової системи на основі структурних перетворень i фінансових інновацій;

- запровадження сучасних електронних технологій;

- зростання ролі інституційних інвесторів (ICI, НПФ, страхових компаній тощо) у здійсненні фінансових інвестицій [1, с. 10-13].

Ці зміни зумовлювали формування теоретичних підходів та концепцій щодо сутності фінансового посередництва. Дослідження специфіки діяльності фінансових посередників у 70-х pр.. ХХ ст. здійснювалися у межах двох теоретичних підходів: трансакційного та інформаційного.

Представники трансакційного підходу (Д.Бенстон, К.Сміт) стверджували, що основне завдання фінансових посередників полягало у задоволенні фінансових потреб клієнтів (заощадників і позичальників) на більш прийнятних умовах і з меншими споживчими трансакційними витратами (consumer borne transaction costs), порівняно 3 прямим фінансуванням. Тобто тут акцент робився на таких перевагах діяльності фінансових посередників, як їх професійна спрямованість (робота на цільовому сегменті ринку, консультування тощо), налагоджена система взаємозв'язків між заощадниками і позичальниками.

Інформаційний підхід у теорії фінансового посередництва знайшов відображення у працях Д.Акерлофа, М.Спенса, та Д.Стігліца, потім він розвинувся у працях Х.Ліленда, Д.Пайла. Т.Кемпбелла, В.Крекоу, Д.Бойда та Е.Прескотта.

Ключовим моментом у межах цього підходу виступає визнання існування феномену асиметричної інформації в умовах ринку. Асиметричність інформації означає піi нерівномірний розподіл між учасниками угоди, чи то покупець кінцевої продукції і продавець, роботодавець та найманий робітник, позичальник і кредитор та інші [2, с.379]. Тобто не всі учасники ринку володіють однаковим обсягом інформації, що створює для одних відносні переваги порівняно 3 іншими. Подібно фінансові посередники під час розробки та реалізації власних фінансових продуктів і послуг одночасно виконують функції інформаційних посередників у процесі збору та продажу надійної інформації потенційним кредиторам про визначені класи активів, що суттєво розширює межі фінансування та сприяє розвитку фінансового ринку.

Дж. Стігліц акцентує увагу на важливій ролі державної політики у сфері фінансового посередництва, що спрямовується на захист інтересів інвесторів, забезпечення прозорості діяльності фінансових посередників, подолання бар'єрів "морального ризику" та "асиметричної інформації" на всіх етапах інвестиційного процесу.

Суттєвий внесок у розвиток теорії фінансового посередництва в межах інформаційного підходу зробив Д.Даймонд на початку 1980-х рр., який є автором концепції "фінансового посередництва як делегованого моніторингу". Ця концепція грунтується на положенні про потребу мінімізації інформаційних витрат для стимулювання поведінки позичальника. Фінансові посередники постають як агенти багатьох інвесторів, які передають посередникам свої кошти та делегують повноваження щодо здійснення моніторингу контрактів. 3 метою скорочення витрат делегування посередники здійснюють випуск власних боргових контрактів 3 фіксованою ставкою та диверсифікують свої портфелі. Тут одразу варто звернути увагу на один суттєвий момент, про який ітиметься і далі: випуск фінансовими посередниками власних фінансових інструментів, що засвідчують уже їхнє зобов'язання. 
Науменкова С. В., Перконос П. П.

\section{Отже, у 70-80-х pp. ХХ ст. на основі 16].} узагальнення трансакційного та інформаційного підходів виникла так звана традиційна теорія фінансового посередництва, розробники якої спробували з'ясувати роль фінансових посередників і причини існування фінансового посередництва. На основі зниження трансакційних витрат і здійснення моніторингу контрактів посередники трансформують неліквідні активи в ліквідні зобов'язання. 3 часом такий перехід отримав назву троїстої трансформації трансформації капіталу, термінів і ризику (capital, maturity and risk transformation) [3, c. 14-15].

У межах напрямку "фінанси та розвиток" $\mathrm{P}$. Левін та О. Галетович досліджували вплив фінансового посередництва на економічне зростання. Ключовою тут $є$ ідея про те, що фінансові посередники не лише забезпечують розширення традиційних галузей економіки, але й сприяють створенню нового виробництва і навіть нових видів діяльності [4, с.689]. Обгрунтування цієї ідеї полягає у тому, що фінансові посередники зорієнтовані на здійснення інвестування в більш дохідні проекти й активи за однакового рівня їх ризику. А технологічні нововведення забезпечують зростання продуктивності праці, що зумовлює притік додаткового капіталу в ці галузі [5, с.320].

Протягом 90-х рр. ХХ ст. на світових фінансових ринках відбувалися подальші зміни, пов'язані 3 процесами глобалізації та інтернаціоналізації ринків фінансових послуг окремих країн. До наукових розробок цього періоду належать праці Ф.Дерека, В.Малпаса, О.Доннела, Е.Балларіна та ін.

Посилення впливу фінансового сектора на економіку зумовило необхідність детальнішого дослідження ролі фінансових посередників у сучасних умовах. Аналізуючи різні підходи науковців до визначення місця та ролі фінансового сектора в економічній системі, можна виділити два протилежні підходи:

1) відповідно до концепції сучасного монетаризму фінансовий сектор - детермінанта економічного розвитку, а отже, збільшення масштабів фінансових ринків сприяє підвищенню ефективності економіки. Диспропорції у розвитку фінансового сектора порівняно 3 реальним тимчасове явище, якого можна (і треба) уникнути;

2) функціонування фінансового сектора в сучасних умовах характеризується певними суперечностями, що перетворюють його на відносно самостійну сферу та вказують на поглиблення розриву ("the great divide") між фінансовим і реальним секторами економіки, так звана гіпотеза "відриву" фінансового сектора від реальної економіки - "decoupling hipothesis" [3, c.
Зростання ролі фінансових посередників та їх діяльності для розвитку економіки та розширення зв'язків між економічними суб'єктами зумовлювало формування різних підходів до тлумачення сутності поняття "фінансовий посередник". Зокрема, на пострадянському просторі це питання розглядали О.Бала, С.Бобров, С.Герасимова, В.Корнєєв.

На думку С.В. Герасимової, фінансові посередники - це сукупність фінансових установ (банки, страхові компанії, кредитні спілки, пенсійні фонди). Ці установи акумулюють кошти фізичних та юридичних осіб, зокрема й шляхом випуску цінних паперів, а потім на комерційних засадах надають ці кошти позичальникам [6]. Тут потрібно звернути увагу саме на комерційний характер діяльності фінансових посередників.

Корнєєв В.В. подає таке визначення фінансових посередників: спеціалізовані оператори фінансового ринку - кредитно-інвестиційні установи, що пропонують і реалізують фінансові послуги як особливий товар на умовах провадження виняткових і поєднаних видів діяльності [7]. Це визначення, з одного боку, ширше, оскільки охоплює діяльність 3 надання фінансових послуг, 3 іншого - воно не передбачає виділення інших, притаманних лише їхній діяльності, особливостей. Також тут слід звернути увагу на фінансові послуги як "товар", що реалізують фінансові посередники.

Відповідно до Закону України "Про фінансові послуги та державне регулювання ринків фінансових послуг" від 12 липня 2001 року №2664III, фінансові послуги - операції з фінансовими активами, що здійснюються в інтересах третіх осіб за власний рахунок чи за рахунок цих осіб, а у випадках, передбачених законодавством, - і за рахунок залучених від інших осіб фінансових активів 3 метою отримання прибутку або збереження реальної вартості фінансових активів [8]. Ключовими моментами ми тут вважаємо здійснення операцій на користь третіх осіб, а також винятково фінансові активи як предмет таких операцій.

О.І. Бала приходить до висновку, що фінансові посередники являють собою фінансові установи, які здійснюють спеціалізоване та універсальне обслуговування учасників ринку 3 приводу акумуляції вільних грошових коштів 3 метою отримання прибутку та задоволення потреб учасників фінансових відносин [9, с. 172-173].

На думку Є.А. Боброва, фінансові посередники є суб'єктами фінансового ринку, а саме фінансовими інститутами (банки та небанківські інститути) та інфраструктурними учасниками (біржі, позабіржові системи, депозитарії), чиї 
функції полягають в акумулюванні коштів фізичних та юридичних осіб і в подальшому їх наданні у розпорядження позичальників на комерційних основах [10]. Тут на увагу заслуговує віднесення до фінансових посередників "інфраструктурних учасників" фінансового ринку. На нашу думку, це суперечливий момент, оскільки такі суб'єкти фінансового ринку (біржі, депозитарії тощо) є "забезпечуючими" інститутами. Вони напряму не надають фінансових послуг клієнтам, не здійснюють трансформації капіталів, термінів і ризиків.

На думку М.І. Савлука, фінансові посередники виступають в якості самостійних і рівноправних суб'єктів грошового ринку, що формують власні зобов'язання та вимоги і на цій підставі емітують власні фінансові інструменти, які стають інструментом торгівлі на грошовому ринку. Крім того, акцент здійснюється на виокремленні фінансового посередництва, враховуючи його відмінність від брокерсько-дилерської діяльності: фінансові посередники діють на ринку від свого імені і за власний рахунок, створюючи власні зобов'язання та власні вимоги, тому їх прибутки формуються як різниця між доходами від розміщення акумульованих коштів і витратами, пов'язаними з їх залученням [11, с. 431].

У продовження підходів до фінансового посередництва як діяльності фінансових посередників, наведемо визначення відомого американського економіста Ф. Мишкіна [12]: фінансове посередництво - це процес непрямого інвестування, за якого фінансові посередники позичають кошти в тих, які їх заощадили, i надають позики іншим. Зауважимо, що таке визначення не $\epsilon$ цілковито повним, оскільки фінансові посередники не лише надають позики (позики надають, як правило, лише банківські установи), а й вкладають кошти в корпоративні права та інші цінні папери, а також надають інші фінансові послуги.

Підсумовуючи та узагальнюючи різноманітні погляди на тлумачення поняття "фінансовий посередник", вважаємо за доцільне звернути увагу на таке. 3 одного боку, фінансові посередники постають як економічні суб'єкти, діяльність яких базується на здійсненні операцій із фінансовими активами у процесі руху грошових коштів від заощадників до позичальників. 3 іншого діяльність фінансових посередників у сучасних умовах здійснюється на основі максимально повної реалізації принципів прийнятності фінансової послуги для клієнта.

Зауважимо, що для сучасної фінансової науки поняття прийнятності фінансової послуги (suitability or appropriateness) відносно нове. У Доповіді спільного форуму Базельського комітету з банківського нагляду, Міжнародної організації комісії регулювання цінних паперів і Міжнародної організації органів страхового нагляду на тему: "Прийнятність для клієнтів у роздрібних продажах фінансових продуктів та послуг" міститься тлумачення цього терміна.

Прийнятність визначається як ступінь того, наскільки продукт або послуга, запропонована посередником, відповідає фінансовому станові роздрібного клієнта, інвестиційним завданням, рівню толерантності до ризику, фінансовій потребі, знанням і досвіду. На сьогодні поняття прийнятності визнається в регулятивних вимогах наглядових органів практично всіх країн світу. Розбіжності у його визначенні та застосуванні різняться як за країнами, так і за секторами, i стосуються обсягів наданої інформації, характеру фінансових послуг і продуктів, повноважень суб'єктів ринку й органів регулювання та нагляду тощо. Фінансова послуга з позиції прийнятності для конкретного клієнта оцінюється 3 огляду на такі їі характеристики, як зручність, доцільність, прозорість, а також рівень відповідності фінансовим потребам клієнтів (вартість послуги, толерантність до ризику, ефективність споживання). Отже, діяльність фінансових установ 3 продажу фінансових продуктів і послуг на основі максимально повної реалізації принципів прийнятності є основою довіри клієнтів до фінансових ринків і спрямована на забезпечення захисту їх прав.

Саме чітке виявлення низки притаманних фінансовим посередникам ознак дозволяє виокремити їх серед інших учасників фінансового ринку та визначити їх роль у розвитку економіки.

Висновки та перспективи подальших досліджень. Дослідження еволюції підходів до визначення сутності фінансових посередників дозволяє більш точно визначити їх місце і роль у сучасних умовах, що зумовлено необхідністю посилення взаємодії між усіма учасниками фінансового ринку та вдосконалення механізму його функціонування. Особливостями діяльності фінансових посередників у сучасних умовах $\epsilon$ максимальна орієнтація на задоволення потреб клієнтів, що випливає не лише зі специфіки економічних відносин, пов'язаних зі здійсненням операцій із фінансовими активами у процесі руху грошових коштів від заощадників до позичальників, але й визначається необхідністю найбільш повної реалізації принципів прийнятності для споживачів фінансових послуг, забезпечуючи при цьому максимальний рівень захисту їх прав. 


\section{Список літератури}

1. Науменкова С.В., Міщенко С.В. Розвиток фінансового сектору України в умовах формування нової фінансової архітектури: монографія. - К.: Університет банківської справи, Центр наукових досліджень Національного банку України, 2009. - 384 c.

2. История экономических учений : (современный этап) : учебн. / [под общ. ред. А. Г. Худокормова]. М. : ИНФРА-М, 1998. - 733с. - (Сер. "Высш. образование").

3. Науменкова С.В. Ринок фінансових послуг: навч. посіб. / С.В.Науменкова, С.В.Міщенко. - К.: Знання, 2010. - 532 c.

4. Levine R. Financial Development and Economic growth : Views and Agenda / R. Levine // Journal of economic Literature. - 1997. - June. - vol XXXV

5. Galetovic A. Finance and Growth: A Synthesis and Interpretation of Evidence, International Finance Discussion Papers / A.Galetovic. - W DC.: 1994. - 477p.

6. Герасимова С.В. Роль фінансових посередників в організації інвестиційної діяльності акціонерних товариств / С.В. Герасимова // Фінанси України. 2007. - № 4. - С. 103-111

7. Корнєєв В.В. Модифікація форм фінансового посередництва в Україні / В.В. Корнєєв // Фінансовий ринок. - 2008. - С. 77-85

8. Про фінансові послуги і державне регулювання ринків фінансових послуг: Закон України від 12 липня 2001 р. №2664-III [Електронний ресурс]. - Режим доступу: http://zakon.rada.gov.ua.

9. Бала O.I., Цізда О.І. Фінансове посередництво в Україні: сутність та види / О.І. Бала, О.І. Цізда // Науковий вісник НЛТУ України. - 2010. - Вип. 20.6. C. $169-173$

10. Бобров Є.А. Роль та місце ринку фінансових послуг у структурі фінансового ринку // Фінанси України. - 2007. - №4. - С. 88-94

11. Гроші та кредит: Підручник. - 3-тє вид., перероб. і доп. / М. І. Савлук, А. М. Мороз, М. Ф. Пуховкіна та ін.; За заг. ред. М. І. Савлука. - К.: КНЕУ, 2002. - 598 с.

12. Мышкин Фредерик С. Экономическая теорія денег, банковского дела и финансовых рынков / Фредерик С. Мышкин - [7-е издание]: пер. с англ.. М.: ООО "М.Д. Вильямс", 2006. - 880 с.

\section{Аннотация}

Свитлана Науменкова, Павло Перконос

\section{ЭВОЛЮЦИЯ ТЕОРЕТИЧЕСКИХ ПОДХОДОВ К РАСКРЫТИЮ СМЫСЛА И РОЛИ ФИНАНСОВОГО ПОСРЕДНИЧЕСТВА}

Рассмотрены особенности деятельности финансовых посредников в современных условиях. Приведена эволючия теоретических подходов к раскрытию сущности и роли финансового посредничества. Раскрыто понятие приемлемости финансовой услуги. Уточнена роль финансовых посредников в процессе предоставления финансовых услуг клиентам на основе реализации принципов приемлемости.

Ключевые слова: финансовые посредники, финансовый рынок, финансовая услуга, приемлемость финансовой услуги.

\section{Summary}

Svitlana Naumenkova, Pavlo Perkonos

\section{EVOLUTION OF THEORETICAL APPROACHES TO DISCLOSURE OF THE ESSENCE AND ROLE OF FINANCIAL INTERMEDIATION}

Peculiarities of financial intermediaries `activity under present-day conditions are considered in the article. Evolution of theoretical approaches to disclosure of financial intermediation essence and role is given. A concept of financial service's appropriateness is exposed. The role of financial intermediaries in the process of financial services rendering to the clients on the base of appropriateness principles is specified.

Key words: financial intermediaries, financial market, financial service, appropriateness of financial service. 


\title{
КОНЦЕПТУАЛЬНІ ОСНОВИ ФОРМУВАННЯ ТА РЕАЛІЗАЦІї ДЕРЖАВНОЇ ПОДАТКОВОї ПОЛІТИКИ
}

\begin{abstract}
Доведено необхідність реформування вітчизняної податкової політики. Досліджено основні підходи до визначення сутності податкової політики. Виявлено вплив податкової політики як інструменту регулювання економіки на соціально-економічний розвиток держави в умовах панування різних економічних доктрин.

Ключові слова: податки, податкова політика, оподаткування, доходи бюджету, податкове регулювання, податковий менеджмент.
\end{abstract}

У більшості країн світу податки є "ефективним знаряддям державної політики" відносно життєдіяльності суспільства, а саме: перерозподілу ВВП у соціальному, віковому, територіальному, галузевих аспектах компенсації недоліків ринкових механізмів, розміщення ресурсів і забезпечення суспільними благами, заохочення бізнесу, ділової та інвестиційної активності, мотивації до праці, антициклічного регулювання економіки, підтримання рівня зайнятості, стабілізації ринкової кон'юнктури.

Актуальність проблеми реформування податкової політики зумовлена тим, що у ході здійснюваних в Україні за роки незалежності реформ відбулися глибокі соціально-економічні перетворення. Разом з тим непослідовність процесів реформування, відсутність цілісної концепції державної економічної політики, значні структурні диспропорції в економіці призвели до глибокої та затяжної соціально-економічної кризи. Одним 3 важливих факторів кризових явищ в Україні стала невиважена податкова політика держави, у результаті якої відбулося гальмування інноваційно-інвестиційних процесів, що призвело до зниження рівня реальних податкових надходжень.

Проблеми формування і реалізації податкової політики досліджували у своїх працях вітчизняні учені А.І. Крисоватий, I.О. Луніна, I.О. Лютий, А.М. Соколовська, Л.Л. Тарангул та сучасні зарубіжні науковці В. Ажаєва, К. Андерсон, Е. Еберхартінгер, К. Мессере, Л. Оксельгейм та інші. Необхідність негайного вирішення проблеми дослідження теоретичних засад формування i реалізації сучасної податкової політики зумовлює

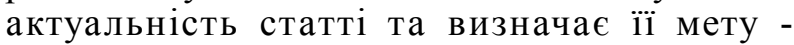
окреслити основні підходи до з'ясування сутності податкової політики та проаналізувати особливості розвитку теорії оподаткування в умовах панування різних економічних концепцій.

Податки в руках одних управлінців можуть бути знаряддям та інструментом стабілізації та економічного процвітання в державі, а в руках інших - нестабільності й економічного саморуйнування.

Дбаючи про формування державних грошових фондів за рахунок податків і податкових платежів та встановлюючи нові види та форми оподаткування, державні структури повинні провадити таку податкову політику, яка має оптимально поєднувати інтереси держави і платників податків. Про оптимальність із погляду платників можна сказати словами французького економіста Леруа Больє: "Найкращий податок це найменший податок". Звичайно, теоретики не можуть сприймати оптимальність так просто й безпосередньо. На їх погляд, вона полягає в максимізації індивідуально очікуваної корисності від різних комбінацій в оподаткуванні: співвідношення прямих і непрямих податків; диференціації оподаткування за окремими секторами економіки (промисловість, сільське господарство, житлово-комунальна сфера); дії окремих податків (податку на прибуток корпорацій, податку з доходів фізичних осіб та ін.).

Успішне проведення податкової політики можливе за умови наукового поєднання таких критеріїв:

- фіскальної достатності;

- економічної ефективності;

- соціальної справедливості;

- стабільності;

- гнучкості [1, с. 124-130].

Ключовим питанням податкової політики $є$ формування податкової системи, орієнтованої на економічне зростання. Висновки економічної теорії та історичний досвід різних країн показують, що економічному зростанню сприяє така податкова система, яка забезпечує достатній рівень доходів держави, але, по можливості, здійснює незначний вплив на функціонування ринкового механізму.

Податкову політику можна розглядати як діяльність держави у сферах запровадження, 
Рожко О. Д.

правового регламентування й організації справляння податків і податкових платежів до централізованих фондів грошових ресурсів держави.

Для досягнення поставлених перед податковою політикою завдань, а також з'ясування ㄲï місця в інтеграційних процесах потрібен глибокий науковий підхід до розуміння сутності податкової політики. Відзначимо, що даний термін складається 3 двох категорій: "політика" та "податки".

В економічних словниках політика визначається як державна наука, мистецтво управління державою. Це тлумачення вказує на те, що суб'єктом політики є держава, а особливістю іiі предмета $є$ владний, наказовий характер. Ще В.I. Ленін вважав, що політика - це упорядковування державної влади; політикою $є$ участь у державних справах, державний напрям, визначення форм, завдань, змісту діяльності держави. Такі визначення були покладені в основу розуміння політики радянською наукою. Р. Коуз запропонував поширити об'єкт дослідження в економічній політиці не лише на макро-, а й на мікрорівень. Він вважав, що метою економічної політики на будь-якому рівні є створення такої ситуації, за якої б люди, ухвалюючи рішення щодо своєї діяльності, вибирали такі варіанти, які забезпечують якомога кращі результати для системи в цілому. Таке тлумачення стало типовим для західної науки [2].

Отже, термін "політика" можна розглядати принаймні у двох напрямках: по-перше, це суспільна наука, по-друге, це особливий вид діяльності на макро- і мікрорівні. При цьому економічна політика $є$ складовою частиною системи державного втручання у регулювання суспільного відтворення.

Прикметник "податкова" у понятті "податкова політика" вказує на сферу докладання зусиль держави у процесі управління. Праці західних економістів не мають чітких визначень категорії "податкова політика". Так, С. Фішер, Р. Дорнбуш, Р. Шмалензі використовують термін "фіскальна

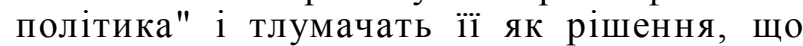
приймаються державними структурами щодо своїх доходів і витрат.

У підручнику "Економікс" Кемпбелла Р. Макконелла та Стенлі Л. Брю поняття фінансовобюджетної та фіскальної політики об'єднані і визначаються як зміни, що вносяться урядом до порядку здійснення державних видатків i оподаткування, спрямовані на забезпечення повної зайнятості та неінфляційного національного продукту. Едвін Дж. Долан, Колін Д. Кемпбелл, Розмарі Дж. Кемпбелл зауважують, що існує два джерела урядового впливу на процес кругообігу доходів у державі, величину номінального національного доходу, а також на ступінь впливу номінальних змін доходу на зміни реальних величин та рівня цін. Це - фіскальна та грошовокредитна політика. При цьому під фіскальною політикою мається на увазі політика уряду у сфері оподаткування і державних витрат. Отже, у працях західних теоретиків термін "податкова політика" не здобув широкого вжитку, а вживається у понятті "фіскальна політика".

Різноманітність підходів щодо визначення сутності податкової політики простежується в працях російських вчених. М.В. Карп зазначає, що "податкова політика $є$ складовою частиною загальної фінансової політики держави на середньострокову і довгострокову перспективи i охоплює такі поняття, як концепція державної діяльності у сфері оподаткування, податковий механізм, а також управління податковою системою держави" [2]. Б.Х. Алієв і А.Н. Абдулгалімов вважають, що "податкова політика - це діяльність держави, що виражена в комплексі заходів, які здійснюється уповноваженими на те органами державної влади і державного управління у сфері податків і зборів, відображаючи класифікацію податків, методи і принципи оподаткування, які діють на законній основі в податковій системі даної держави" [3]. "Будучи явищем багатокомпетентним і складним, - пише M.Н. Карасьов, - податкова політика розглядається як сукупність організаційних, економічних і правових заходів, що забезпечують на єдиних принципах обгрунтовану систематичну діяльність органів держави, спрямовану на оптимальне, повне та адекватне регулювання оподаткування" [4].

Аналогічні російським наукові підходи щодо з'ясування сутності податкової політики пропонуються також вітчизняною науковою думкою (табл. 1).

Отже, аналіз різних підходів до визначення категорії "податкова політика" дозволяє сформулювати такі висновки:

- податкова політика - це діяльність держави у сфері оподаткування;

- податкова політика - це сукупність правових, економічних і організаційних заходів у сфері регулювання податкових відносин;

- податкова політика повинна бути спрямована на забезпечення податкових надходжень і стимулювання економічного зростання;

- податкова політика є складовою частиною загальної фінансової політики держави на середньо- та довгострокову перспективи;

- податкова політика реалізується в рамках податкової системи держави;

- регламентованість податкової політики законодавча. 


\section{Визначення поняття "податкова політика" у працях вітчизняних науковців}

\begin{tabular}{|c|c|}
\hline Автор & Запропоноване визначення \\
\hline $\begin{array}{l}\text { Юрій С.І., Бескид } \\
\text { Й.М. }\end{array}$ & $\begin{array}{l}\text { Податкова політика - діяльність держави у сфері встановлення, правого } \\
\text { регламентування та організації збору податків і податкових платежів у } \\
\text { централізовані фонди грошових ресурсів }\end{array}$ \\
\hline Крисоватий A.I. & $\begin{array}{l}\text { Податкова політика - це діяльність держави у сферах запровадження, } \\
\text { правового регламентування та організації справляння податків та } \\
\text { податкових платежів, які є знаряддям розподілу та перерозподілу частини } \\
\text { валового внутрішнього продукту та формування централізованих фондів } \\
\text { грошових ресурсів держави }\end{array}$ \\
\hline $\begin{array}{l}\text { Федосов В.М., } \\
\text { Опарін В.М., } \\
\text { П’ятаченко Г.О. }\end{array}$ & $\begin{array}{l}\text { Податкова політика - це діяльність держави у сфері встановлення і } \\
\text { стягнення податків, зокрема } 3 \text { формування державних доходів за рахунок } \\
\text { постійних і тимчасових джерел, установлення видів податків, платників, } \\
\text { об'єктів, ставок, пільг, механізму зарахування }\end{array}$ \\
\hline Василик О.Д. & $\begin{array}{l}\text { Податкова політика - це державна політика оподаткування юридичних і } \\
\text { фізичних осіб. ЇІ метою є формування державного бюджету за одночасного } \\
\text { стимулювання ділової активності }\end{array}$ \\
\hline $\begin{array}{l}\text { Іванов Ю.Б., } \\
\text { Тищенко О.М. }\end{array}$ & $\begin{array}{l}\text { Податкова політика - це система відносин, які складаються } \\
\text { між платниками податків і державою, а також стратегія їх дій у різних } \\
\text { умовах ведення господарства і різних економі чних системах }\end{array}$ \\
\hline Соколовська А.М. & $\begin{array}{l}\text { Сучасна податкова політика полягає у встановленні і зміні елементів } \\
\text { податкової системи (різновидів податків, ставок, структури, суб'єктів, } \\
\text { об’єктів оподаткування, пільг тощо) для забезпечення надходжень до } \\
\text { бюджету, достатніх для виконання державою покладених на неї функцій і } \\
\text { стимулювання економічного зростання }\end{array}$ \\
\hline $\begin{array}{l}\text { Данілов О.Д., } \\
\text { Фліссак Н.П. }\end{array}$ & $\begin{array}{l}\text { Податкова політика - система заходів, які проводяться урядом країни щодо } \\
\text { вирішення певних коротко- та довгострокових завдань, які стоять перед } \\
\text { суспільством, за допомогою системи оподаткування }\end{array}$ \\
\hline Ісаншина Г.Ю. & $\begin{array}{l}\text { Податкова політика - це система дій, які проводяться державою в галузі } \\
\text { податків та оподаткування. Податкова політика знаходить своє } \\
\text { відображення у видах податків, розмірах податкових ставок, } \\
\text { визначенні платників і об’єктів оподаткування, в податкових пільгах }\end{array}$ \\
\hline
\end{tabular}

На підставі цього пропонуємо таке визначення сутності податкової політики з урахуванням тенденцій глобалізації економічних систем і посилення інтеграційних процесів у світі. Податкова політика держави - це сукупність правових, економічних і організаційних заходів держави у сфері оподаткування щодо регулювання податкових відносин, які спрямовані на забезпечення надходжень податків до централізованих фондів грошових ресурсів держави й стимулювання економічного зростання за допомогою податкової системи. Вона визначається ступенем впливу держави на соціально-економічні процеси і змінюється під впливом інтеграційних процесів, що відбуваються у світогосподарських зв'язках. Урахування останнього фактора зумовлене тим, що важливою ланкою процесу економічної інтеграції, особливо на сучасному етапі його розвитку, стало зближення (гармонізація) національних податкових систем. Так, досвід європейських країн у формуванні і реалізації податкової політики має велике значення для України, особливо з огляду на те, що вона прагне до набуття повного членства в європейських організаціях i міждержавних утвореннях.

Заходи держави у сфері оподаткування визначаються цілями і завданнями податкової політики, які обумовлені соціально-економічним устроєм суспільства, соціальними групами, що знаходяться при владі, стратегічними цілями, що визначають розвиток національної економіки, i міжнародними зобов'язаннями у сфері державних фінансів.

Завдання кожного уряду - це досягнення оптимального рівня оподаткування, який би 
Рожко О.Д.

забезпечував баланс державного бюджету i соціальну стабільність. Відповідь на ці питання якоюсь мірою дає концепція економіки пропозиції, яка була використана урядами провідних держав світу і принесла успіхи, зокрема у США та Великобританії у 80-х рр. ХХ ст. під назвою "рейганоміка" i "тетчеризм" відповідно.

Податкова політика у 70-80-ті роки XX ст. у розвинутих країнах здійснювалась у рамках нового курсу економічної політики, що змінився в зв'язку з переходом влади від сил реформістських, що застосовували принципи кейнсіанства, до консервативних, монетаристів, пріоритетами яких були грошово-кредитне регулювання та зміцнення ринкових засад функціонування національних економік.

У період світової фінансової кризи, коли економічна політика багатьох держав зазнала якщо не краху, то суттєвого погіршення, напрацювання провідних економістів світу мають бути покладені в основу відновлення рівноваги, а потім і зростання. Теорія економіки пропозиції (ТЕП) - одна 3 найважливіших течій сучасного економічного консерватизму. Ідеї, які визначили зміст концепції, були висловлені у другій половині 70-х pp. XX ст. деякими американськими конгресменами і сенаторами під час обговорення стану та перспектив бюджетної політики США. Термін "теорія економіки пропозиції" або "сепплайсайд економікс" (supply-side economics) був вперше використаний американським фахівцем 3 питань бюджетно-податкової політики Г. Стейном у 1976 p. [5, с.1045].

Оподаткування $є$ важливим чинником економічного зростання, тому сучасні дослідники Е. Аткінсон, А. Діксіт, Дж. Мірліс, Дж. Стігліц та ін. здійснили спробу проаналізувати його оптимальний рівень. Внаслідок цього вони зробили висновок, що:

1) однорідність оподаткування не завжди нейтральна;

2) спеціальні умови, при яких однорідність оподаткування визначеного набору товарів або видів діяльності мінімізує чисті втрати від адміністрування визначеної суми податкових надходжень, виконуються, коли рівноважна кількість (або рівень діяльності) кожного елементу оподаткованого набору в однаковій пропорції реагує на однорідний (гіпотетичний) податок на всі товари або види діяльності, які не входять у цей набір;

3) якщо попередня умова не виконується, то замість однорідного оподаткування мінімізація чистих витрат потребує оподаткування за ставкою вище середньої тих товарів, кількість яких зменшується в результаті введення однорідного податку на об'єкти, які не входять у набір, і оподаткування за ставкою нижче середньої на ті об'єкти, рівноважна кількість яких зростає найбільш різко [6, с.628-629].

Також у 70-ті роки XX ст. внаслідок розвитку виробничих відносин виявляються суперечності кейнсіанських методів державного втручання. У цей час уповільнилися темпи економічного зростання економіки західних країн, зросли бюджетний дефіцит, державний борг та інфляція. В умовах поглиблення кризи 1974-1975 та 19801982 рр. постало питання про перегляд домінуючої економічної концепції. На місце кейнсіанських методів регулювання приходить неокласична теорія i, зокрема один 3 iі напрямів неоконсерватизм. Кейнсіанський підхід до повного використання ресурсів і економічної рівноваги, заснований на "ефективному попиті", в досягненні якого важливе місце відведено державі, поступається місцем неокласичному, відповідно до якого ринкове господарство не повинно обмежуватися державним втручанням, оскільки вільна конкуренція сама створює оптимальні можливості для забезпечення економічної рівноваги. Кейнсіанське твердження про те, що рівень безробіття залежить від попиту і $\epsilon$ примусовим, відкидається; безробіття проголошується добровільним. Відмітності в економічних доктринах кейнсіанства та неоконсерватизму зумовили різний підхід до методів регулювання економіки. Проте навіть за цих нових умов мова йшла лише про зміну методів, а не про повне скасування державного втручання. Зміна в методах регулювання пов'язана, насамперед, 3 істотною переорієнтацією пріоритетів бюджетної та податкової, кредитної та грошової політики [7].

Сучасна теорія оподаткування розвивається в межах економіки суспільного вибору. Видатний іiі представник Дж. Б'юкенен у праці "Державні фінанси в умовах демократії" розглядає податки як прямі витрати громадян за надані урядом послуги, тому метод їхнього утримання може істотно вплинути на ставлення громадян до розширення чи скорочення обсягу наданих послуг [8, c. 117$]$.

Висновки Дж. Б'юкенена не можна вважати надбанням будь-якої з податкових теорій, які досліджують поведінку платника у сфері його приватної діяльності. Дослідник пішов далі, він вивчив поведінку суб'єктів оподаткування у суспільно-соціальній сфері.

Особливої актуальності в цьому контексті набувають наукові дослідження лауреатів Нобелівської преміі 1996 року - професорів У. Вікрі (США) та Дж. Мерлі (Велика Британія). Перший поділяє суспільство на людей активних i працьовитих та схильних до неробства. Останні 
втрачають свої потенційно можливі доходи і тим самим залишають державу без фіскальних надходжень. На цій підставі він приходить до висновку, що найбільший податковий тягар лягає на талановитих і працьовитих людей. Тож задля сприяння прогресу доходи талановитих людей зовсім не повинні оподатковуватися.

Другий доводить: щоб уникнути дестимулювання економічної активності, податки мають бути пропорційними і рівень ставки податку не повинен перевищувати 20 відсотків. Обидва автори сходяться на думці, що високі податки у будь-якому разі призводять до неповного використання продуктивних можливостей платників. У кінцевому підсумку матимемо звуження потенційно можливої бази оподаткування та скорочення доходів бюджету $[9$, с.165].

Отже, підсумовуючи багатовіковий досвід дослідження місця й ролі податків у суспільстві представниками різних наукових шкіл, можна зробити узагальнення: податки розглядаються як обов'язкові платежі, що використовуються для фінансування суспільних благ і послуг; вони є дієвим засобом фінансової політики держави для впливу на розміщення ресурсів, перерозподіл багатства, суспільний вибір громадян у демократичному суспільстві.
Список літератури

1. Романенко О. Р. Фінанси: Підручник. - К: Центр навчальної літератури, 2006.-312c.

2. Карп М. В. Налоговый менеджмент: учебник для вузов / М. В. Карп. - М. : ЮНИТИ-ДАНА, 2001. - 477 с.

3. Алиев, Б. Х. Теоретические основы налогообложения : учеб. пособие / Б. Х. Алиев, А. М. Абдулгалимов ; под ред. А. 3. Дадашева. - М. : ЮНИТИ-ДАНА, 2004. - 159 с.

4. Карасев М. Н. Налоговая политика и правовое регулирование налогообложения в России / М.Н. Карасев. - М. : Вершина, 2004. - 224 с.

5. Історія економічних учень: Підручник / За ред. В.Д. Базилевича. - К.: Знання, 2004. - 1300 с.

6. Экономическая теория / Под ред Дж. Итуэлла, М. Милгейна, П. Ньюмери: Пер. с англ. - М.: ИНФРАМ., 2004. - 931 c.

7. Кейнс Дж. Общая теория занятости, процента и денег / Дж. Кейнс. - М.: Изд-во "Прогресс", 1978. - 548 c.

8. Демиденко Л.П. Розвиток теорій оподаткування вченими Заходу// Фінанси України. - 2004, № 5. - С. $117-124$.

9. Андрущенко В.Л. Фінансова думка Заходу у XX столітті: (теоретична концептуалізація і наукова проблематика державних фінансів). - Львів: Каменяр. $-2000 .-305$ c.

\section{Аннотация \\ КОНЦЕПТУАЛЬНЫЕ ОСНОВЫ ФОРМИРОВАНИЯ И РЕАЛИЗАЦИИ ГОСУДАРСТВЕННОЙ НАЛОГОВОЙ ПОЛИТИКИ}

Александр Рожко

Доказана необходимость реформирования отечественной налоговой политики. Исследованы основные подходы к определению сущности налоговой политики. Обнаружено влияние налоговой политики как инструмента регулирования экономики на социальноэкономическое развитие государства при условии господства разных экономических доктрин.

Ключевые слова: налоги, налоговая политика, налогообложение, доходы бюджета, налоговое регулирование, налоговый менеджмент.

\section{Summary}

Oleksandr Rozhko

\section{CONCEPTUAL BASES OF FORMING AND REALIZATION OF PUBLIC TAX POLICY}

The necessity of reformation of domestic tax policy is well-proven in the article. The basic ways of determination of essence of tax policy are investigated. The influence of tax policy as instrument of adjusting of economy on socio-economic development of the state in condition of domination of different economic doctrines is found out.

Key words: taxes, tax policy, taxation, profits of budget, tax adjusting, tax management. 
УДК 338.2

\section{(C) Третякова О.В., Онопко М.О., 2011 \\ Чернівецький національний університет імені Юрія Федьковича, м. Чернівці}

\section{РОЛЬ ДЕРЖАВИ В СОЦАЛІЗАЦЇ̈ ЕКОНОМІКИ: ФІНАНСОВИЙ АСПЕКТ}

Розглядається роль уряду в забезпеченні соціального захисту населення $і$ можливості підвищення ефективності регулювання. На основі досвіду крайн ОЕСР та Свропейського Союзу оцінюються напрямки зміни підходів до сочіального забезпечення та його фінансування, а також вплив моделі соціального забезпечення на економічне зростання та людський розвиток та можливості їх застосування в Україні.

Ключові слова: держава, сочіальні витрати, держава загального добробуту, сочіальне ринкове господарство.

Роль держави в економіці та суспільному житті постійно стає предметом для суперечок учених, погляди яких представлені широким спектром підходів: від анархізму, що відстоює ідею відсутності держави як такої, до тоталітарного соціалізму, представники якого вважають необхідним встановлення повного контролю держави над економічним та соціальним життям, більшість дослідників мають погляди між даними крайнощами, які сильно відрізняються.

У традиційній неокласичній моделі економіки, існують ринки для будь-чого як зараз, так і в майбутньому, всі мають досконалу інформацію, $\mathrm{i}$ ця інформація однакова для всіх, не існує суспільних благ, немає екстерна дій, трансакційних витрат, не існує зростаючих віддач. Оскільки за даних припущень ринок установлює найоптимальніше розмішення ресурсів, державне втручання в економіку провокує переміщення доходів, внаслідок чого виникає відхилення від конкурентної рівноваги й оптимального розміщення ресурсів, зменшення стимулів та неправильної інформації про ринкові можливості. Висновок, що витікає 3 даної моделі: оскільки держава не має що запропонувати ринку, будь-які дії завдають шкоду.

Усе ж такий підхід характеризується негативними характеристиками, такі як відсутність суспільних благ, екстерналій, трансакційних витрат, та монополій - що вказує на прямі невідповідності, оскільки за наявності вказаних "провалів" ринок вже не забезпечує ефективний розподіл. Вищевказані спостереження лягли в основу доктрини державного втручання: "ринки там, де можливо, держава, коли необхідно". Головною настановою, яка з'явилася 3 цих спостережень, було те, що ринки мають діяти там, де вони діють ефективно - розподіл приватних благ, коли приватна ставка окупності співпадає 3 суспільною окупністю, тоді як держава має забезпечувати виробництво суспільних благ,

сприяти угодам, коригувати екстерналії та здійснювати регулювання монополій відповідно до зростання віддачі від вкладень.

Забезпечення соціального захисту $\epsilon$ обов'язком уряду, але приватні витрати також становлять значну частину загальних витрат, хоча саме держава визначає загальну спрямованість соціальної політики. Надання можливості приватному сектору забезпечувати соціальний захист дозволяє диверсифікувати інвестиційний ризик, може призводити до зниження витрат i призвести до запровадження інновацій у наданні послуг та формуванні програм, але водночас для того, щоб залучати приватні зусилля, держава повинна сформувати інституційну основу для вказаного виду діяльності. У трансформаційній економіці перед державою постає складне завдання, оскільки вказаний тип економічної системи характеризується інституційним вакуумом у багатьох сферах суспільного життя.

Загалом, ОЕСР та ООН соціальні витрати визначають як забезпечення приватним та публічним сектором переваг, фінансових внесків для домогосподарств та індивідів, щоб забезпечити підтримку в обставинах, які негативно впливають на їх добробут. За умови, що надання такої підтримки та фінансової допомоги не полягає ні у сплаті за визначені товари чи послуги, ні індивідуального контракту або передачі матеріальних цінностей[11]

У Свропейському Союзі більшість держав прикладають значні зусилля для подолання проблем бідності та соціальної нерівності. Останнім часом такі дії характеризуються обміном досвідом між країнами. Тому головним питанням залишається те, чим визначається різниця в результатах застосування певних заходів, а також вплив вказаних заходів на економічний розвиток. Держава є не єдиним суб'єктом, що здійснює витрати на соціальне забезпечення. У розвинених демократіях зі 
сформованим громадянським суспільством існує значний вплив добровільних приватних витрат на соціальне забезпечення. Але визначально, на рівень витрат на соціальне забезпечення впливає податкова система, оскільки уряд оподатковує певні об'єкти та визначає обов'язкові відрахування на соціальне забезпечення. У розвинених країнах найважливішим джерелом наповнення бюджету $\epsilon$ прямі податки, оскільки об'єкт оподаткування забезпечує достатній обсяг податкових надходжень для виконання функцій держави, а також існують механізми мінімізації ухилення від сплати податків. А у трансформаційній економіці переважають непрямі податки, оскільки оподаткування споживання дозволяє в тому числі забезпечувати регулювання попиту та пропозиції, стимулювати заощадження, вирівнювати індивідуальні доходи громадян, стимулювати індивідуальну підприємницьку діяльність, стримувати інфляцію [4, с. 310].

За даними ОЕСР, урахування внеску податкової системи та приватних витрат на соціальне забезпечення призводить до зближення часток витрат на соціальний захист відносно ВВП i переоцінки значення держави добробуту. Зазвичай, Данія та Швеція розглядаються як країни, що здійснюють найбільші витрати на соціальне забезпечення, але після врахування впливу оподаткування частка соціальних витрат у ВВП виявляються найвищими у Франції, Німеччині та Швеції[7].

Концепція держави суспільного добробуту розглядається як модель для побудови економічної системи майбутнього, головним завданням соціальної політики $є$ надання високого прожиткового мінімуму членам суспільства, створення відповідних можливостей для реалізації власного потенціалу та отримання винагороди, екологічна безпека, захист закону та порядку[1, c.27]. Втім, викликає сумніви можливість поширення вказаної моделі на менш економічно розвинуті країни та країни 3 перехідною економікою, оскільки зростання рівня життя в цих країнах неможливе без тривалої макроекономічної стабільності, структурних зрушень, а прискорення темпів зростання виробництва невідворотно призводить до загострення глобальних проблем, оскільки призводить до підвищення навантаження на екосистему.

Академік І. Лукінов зазначає, що для економіки України надзвичайно важливе питання розвитку продовольчої сфери, переорієнтації на сучасні методи ведення діяльності в цій сфері, оскільки продовольча безпека є важливою складовою соціальної політики в країнах 3 перехідною економікою, де витрати на продовольство досягають до 70 \% витрат населення [3, с. 386].
Витрати держави на соціальне забезпечення як частка до ВВП часто використовується як показник добробуту для порівняння рівня розвитку держави. Виділяють три аспекти податкової політики, які чинять вплив на соціальні витрати: по-перше, уряд може стягувати прямі податки та соціальні внески на грошові перерахування; подруге, уряд може стягувати непрямі податки 3 осіб, що споживають певні товари та послуги; потретє, уряд може досягати цілей соціальної політики через оподаткування, надаючи податкові пільги, що рівнозначно грошовим виплатам, або надання податкових переваг 3 метою стимулювання надання соціальних гарантій приватному сектору. В практиці міжнародних організацій використовується показник чистих витрат на соціальне забезпечення, який враховує вищевказані аспекти та забезпечує відображення реального внеску держави у соціальне забезпечення.

У Свропейському Союзі здійснюються заходи для того, щоб створити конкурентоспроможну та засновану на знаннях економіку, яка характеризувалась би сталим економічним розвитком і більшою соціальною прозорістю. А відтак економічні та політичні питання поєднувалися б у стратегії розвитку й сама соціальна модель повинна модернізуватися.

В водночас намагання бути більш бережливими 3 боку урядів вступає в суперечність 3 ідеєю підтримки загального високого рівня споживання та достатнього рівня виробництва суспільних благ. Безумовно, необхідне врегулювання наявної соціальної структури та гарантій 3 більш жорсткою та ефективною фіскальною політикою. У зв'язку 3 чим необхідно змінити погляди суспільства на роль держави у підтриманні добробуту громадян.

Відхід від патерналістської держави, модель якої була успадкована більшістю держав Західної Європи ще 3 традиції Римської імперії, і яка розглядається як недостатньо ефективна, проявляється у зрушеннях до децентралізації, приватизації, а також інших формах делегування влади, в тому числі взаємодії 3 неурядовими організаціями та іншими інститутами громадянського суспільства. У процесі реформування виявлялися тенденції до переорієнтації державної служби (в основному в питаннях мобільності, оплати досягнутих результатів, заохочень за ефективну роботу), також великий наголос робився на важливості професіоналізму та професійної етики, заходів щодо захисту громадян від незадовільного управління та зловживання владою. Таке зближення практики управління в державах Свропейського Союзу заслуговує на увагу, 
розбіжності в яких виявляються на двох рівнях: оцінка впливу глобалізації й адміністративна культура. На території континентальної Європи населення більше усвідомлює необхідність додаткових витрат, пов'язаних 3 глобалізацією, перш за все такі витрати стосуються зниження стабільності зайнятості та погіршення стану навколишнього природного середовища. Сам Європейський Союз виявляється чудовим інструментом для того, щоб мінімізувати ризики, пов'язані з глобалізацією та поєднати зусилля багатьох країн у протистоянні 3 силами глобалізованого світу.

Водночас серед науковців викликає сумніви можливість успішного розвитку економіки Європейського Союзу, оскільки порівняно 3 темпами розвитку США, країни СС виглядають як менш конкурентоздатні, оскільки спостерігається досить високий рівень безробіття. Щоб стати лідером в економічному розвитку, було запроваджено "Лісабонську Стратегію". Спостереження показують, що менші темпи розвитку не є проблемою ЄС як цілого, оскільки деякі країни розвивалися більш успішно. Водночас успішний розвиток країн, яким притаманний ринковий спосіб узгодження інтересів, менший рівень соціального забезпечення з боку держави та регулювання зайнятості, виявляється дискусійним питанням, оскільки для суспільства перехід до такої моделі неприйнятні, і реакція громадянського суспільства проявляється у формі страйків і завдає значних втрат національній економіці.

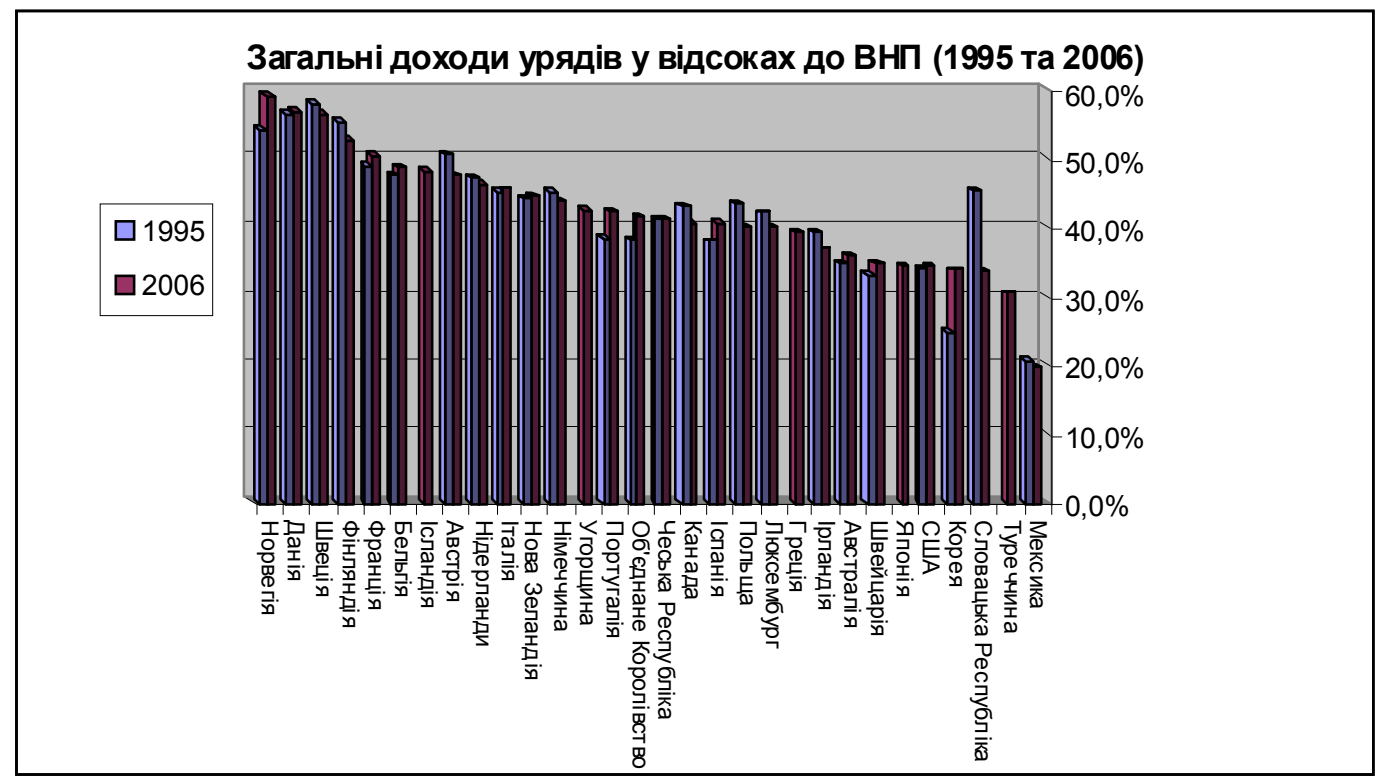

Рис.1. Загальні доходи урядів у відсотках до ВНП 1995 і 2006

Джерело: складено за [12]

Як видно з рис.1, частка доходів урядів більшості розвинутих країн у ВНП не змінюється значно, а також можна виділити декілька груп країн. Перша група - Данія, Фінляндія, Швеція, Нідерланди характеризується високим рівнем витрат на соціальний захист населення, а відтак: високою часткою доходів держави до ВНП; соціальними гарантіями, які рівні для всього населення; активною політикою на ринку праці; високим рівнем ефективності національної економіки; ціновою стабільністю.

Країни 3 англо-саксонською моделлю Австралія, США, Ірландія, Об'єднане Королівство, Канада, Нова Зеландія характеризуються підходом до соціальної підтримки як необхідності для тих верств населення, які надзвичайно сильно цього потребують. При цьому існує велика диференціація рівнів оплати праці, а частка низькооплачуваних працівників в економіці достатньо висока. Проблема соціального захисту переважно розв'язується на рівні підприємств та профспілкових об'єднань.

Континентальна модель характеризує Австрію, Бельгію, Німеччину, Люксембург, Францію, в цих країнах захист від негативних наслідків безробіття та схеми пенсійного забезпечення в основному засновані на страхуванні, а також на соціальному партнерстві 3 метою уникнення конфліктів в суспільстві.

Середземноморська модель (Греція, Італія, Португалія, Іспанія) характеризується перекладанням соціальної відповідальності значною мірою на сім'ю за допомогою та стиснутою структурою заробітної плати [9, С.4]. 


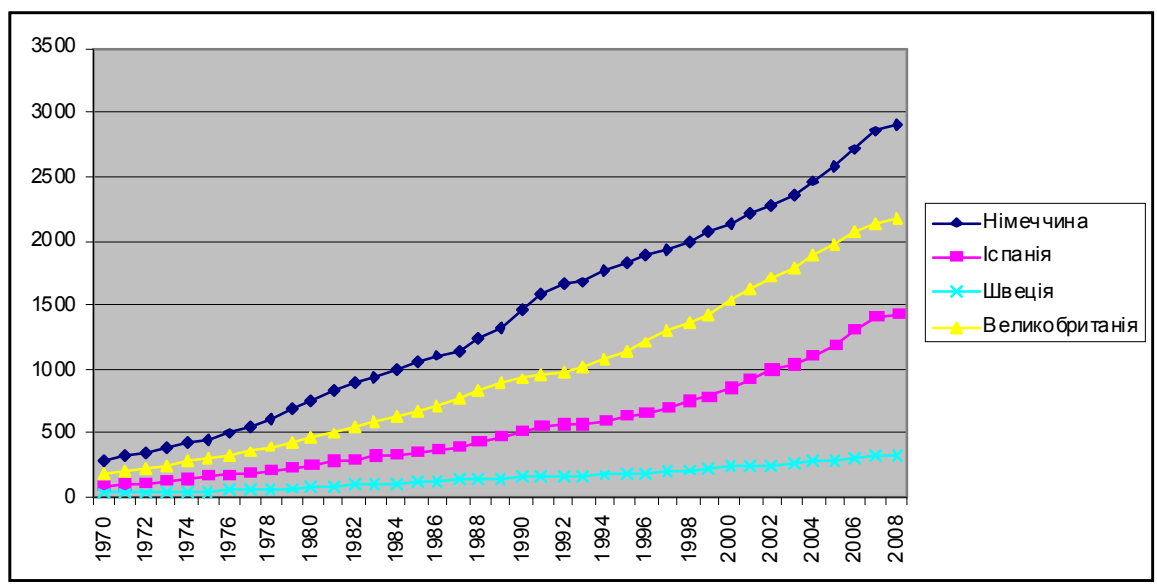

Рис 2. ВНП у 1970-2008 рр., млн. дол. США, ПКС

Джерело: складено за [13].

На рис. 2 показано зростання ВНП у 4 країнах Європи. Звичайно, обсяг ВНП не дозволяє оцінити якість зростання, тому для оцінки не лише ВНП, але і рівня освіти населення, очікуваної тривалості життя при народженні, варто розглянути показники людського розвитку для даних країн. Німеччина у 1980 році мала показник 0,869 , у 2007 - 0,947, Іспанія - 0,855 та 0,955 , Швеція - 0,885 та 0,963 , Великобританія - 0,861 та 0,947 [2, С. 167]. Як бачимо, країни, які перерозподіляють більшу частину ВНП через бюджет, мають більший рівень людського розвитку, що зумовлено наявністю можливості фінансування охорони здоров'я, освіти та інвестування у наукові дослідження та розробки, фундаментальну науку. В Україні у 2011 році доходи бюджету заплановано на рівні 28,7 \% від ВВП [14], що співвимірно 3 показником Туреччини, Мексики і досить сильно відрізняється від показників європейських країн. Індекс людського розвитку становив 0,796 , що характерно для країн з середнім рівнем розвитку людського потенціалу. Але зазначимо, що рівень грамотності та залучення населення у процес навчання - один 3 найвищих у світі. Очікувана тривалість життя 68,2 роки, тоді як нормативний показник для розрахунку індексу - 80 років, що свідчить про недостатню ефективність охорони здоров'я та захисту навколишнього природного середовища.

Отже, в сучасних умовах необхідним $є$ реформування системи соціального забезпечення та визначення середньострокових орієнтирів розвитку та достатня гнучкість соціальної політики для забезпечення економічного розвитку. Втім, у державній політиці має враховуватися висока залежність політичних та економічних програм від умов надання кредитів міжнародними фінансовими інституціями, оскільки зовнішній чинник може вплинути на виконання державного бюджету та на можливості розвитку в подальшому. Особливо це проявляється в умовах енергетичної залежності від зовнішнього світу та відновлення попиту на світових товарних ринках, що призводить до зростання цін на енергоносії. Також необхідно врахувати специфіку інституційного середовища трансформаційної економіки, необхідність зменшення соціального напруження та проведення реформування системи соціального забезпечення для гармонізації взаємодії державного та приватного інтересів.

Модель соціальної ринкової економіки $\epsilon$ спробою зменшити соціальне напруження, комбінуючи ефективність вільної ринкової економіки зі згладжуванням соціальних дисбалансів, це політична концепція економічного порядку. Назва "соціальне ринкове господарство" визначає теоретичний підхід до проведення економічної політики та практику господарювання, що до цього часу провадиться у Німеччині. Але, як свідчить рис.3, витрати держав ОЕСР на соціальні потреби є значними і мають велике значення навіть в ліберальних економіках. Указана модель також декларувалася як мета реформування економіки України в процесі переходу від командно-адміністративної до ринкової економіки. Проте головним питанням залишається можливість застосування цієї моделі як зразка, враховуючи, що Україна має надзвичайно своєрідне розташування у геополітичному та історичному аспектах, оскільки саме тут фактично і відбувається "зіткнення цивілізацій", що породжує необхідність еволюційних змін у практиці регулювання та гармонізації запозиченої моделі з реальними умовами. Ще одним аспектом, який необхідно врахувати, $є$ інституційна структура економіки, а саме: особливості, притаманні трансформаційній економіці - етатизм, відсутність безособового 


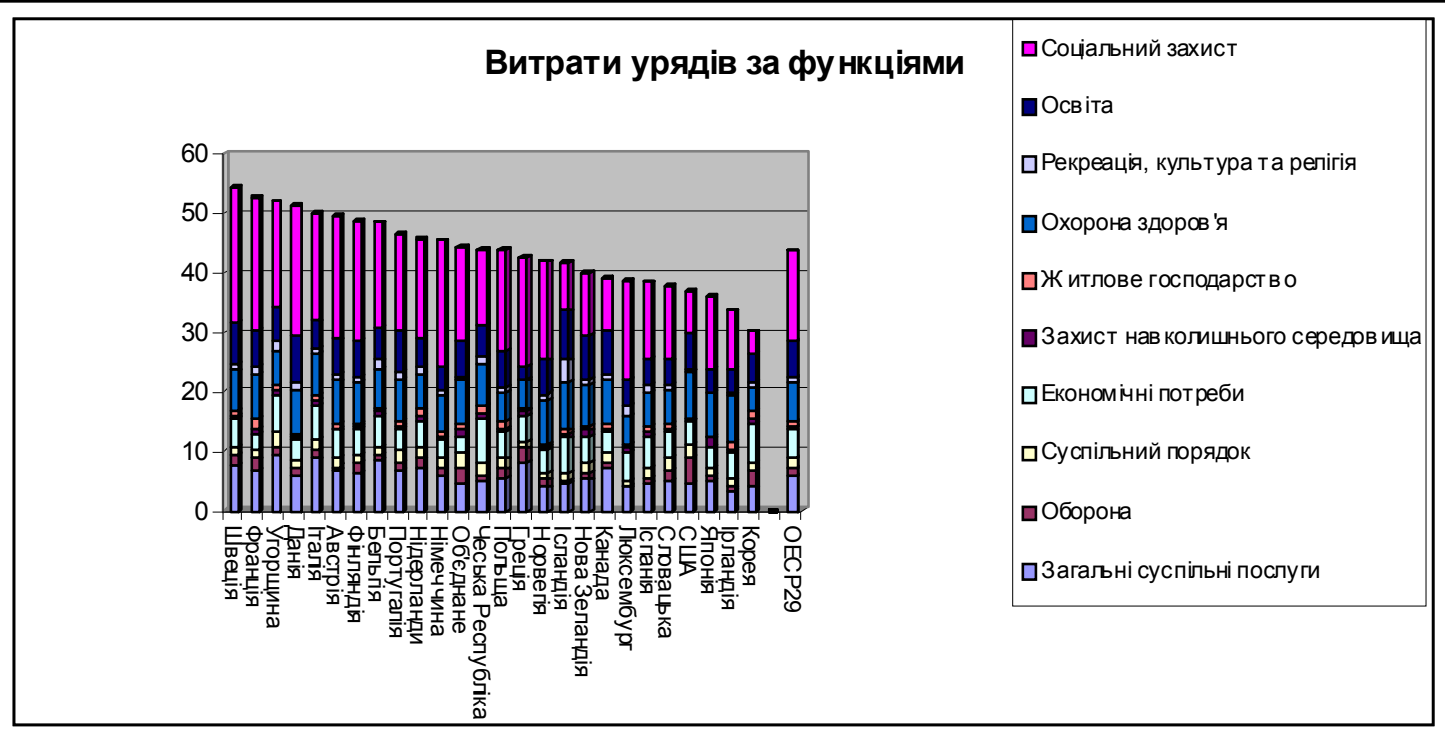

Рис.3. Витрати урядів за функціями, \% до ВНП

Джерело: Government at a Glance 2009, OECD.

обміну та довіри в суспільстві, високі трансакційні витрати, невизначеність прав власності, та правовий нігілізм, притаманний абсолютній більшості населення. Останній породжує проблеми в соціальній сфері, оскільки суспільні блага споживаються всіма членами суспільства, хоча значна частина населення здійснює діяльність у незареєстрованній економіці. Парадоксальним $\epsilon$ те, що при цьому кожен 3 них вважає обов'язком держави забезпечити соціальні гарантій, рівні 3 іншими, працюючими в легальному секторі, тобто фактично перекласти на них власні витрати.

Підсумовуючи, зазначимо, що питання про роль держави в економіці є складним саме тому, що повноваження органів державної влади мають бути такими, щоб відповідати покладеним на них функціям та інтересам суспільства. Попри існування великої кількості точок зору на роль держави в економіці та впливу іiі діяльності на соціальний розвиток, можна виділити ряд умов, які забезпечують ефективність державної соціальної політики: по-перше, наявність розвиненого громадянського суспільства, здатного забезпечити ефективне узгодження суспільних та приватних інтересів; по-друге, застосування адекватної системи пільг і привілеїв 3 переважанням пільг для малозабезпечених верств населення та скорочення кількості привілеїв для інших; по-третє, проведення активної політики професійної орієнтації молоді та перекваліфікації працівників 3 врахуванням стратегічних орієнтирів розвитку країни; почетверте, запровадження середньо- та довгострокового планування та виконання вказаних планів; по-п'яте, подолання корупції та скорочення нелегальної діяльності; по-шосте, забезпечення дотримання збалансованості у розподілі ризиків між приватними особами та державою, реальне зростання заробітної плати повинне відповідати приросту продуктивності праці з метою уникнення дисбалансів у економіці.

\section{Список літератури}

1. Борецька Н.П. Соціальний захист населення на сучасному етапі: стан і проблеми. Монографія / Н.П.Борецька. - Донецьк: Янтра, 2001. - 352 с

2. Доклад о развитии человека 2009. Преодоление барьеров: человеческая мобильность и развитие. // ПРООН. - Издательство "Весь мир". - 2009. - 229 с.

3. Лукинов И.И. Эволюция экономических систем/ И.И.Лукинов.- М.: ЗАО "Издательство "Экономика", 2002. - 567c. - (Российские академики об экономике

4. Лютий І.О., Дрига А.Б. Петренко М.О. Податки на споживання в економіці України./ I.О.Лютий, А.Б.Дрига, М.О.Петренко - К.: Знання, 2005. - 335 с,

5. Чиркунов О. Экономическое чудо: рынок и культура. // Вопросы экономики № 9, 2010 с. 15 - 26. C.22.

6. Barro, Robert J., "Government Spending in a Simple Model of Endogenous Growth,"Journal of Political Economy, 98 (October 1990), s103-s25.

7. Caminada, Koen and Goudswaard, Kees. Social expenditure and poverty reduction in the EU15 and other OECD countries.[Електронний ресурс] Режим доступу http://mpra.ub.uni-muenchen.de/20138/

8. Grossman, Philip J., 1990, "Government and Growth: Cross-sectional Evidenece," Public Choice Vol.65: 217227.

9. Klaus Dieter John. The German Social Market Economy - (Still) a Model for the European Union. //. Theoretical and Applied Economics. - p. 3 - 10.

10. Levine, Ross and David Renelt, 1992, "A Sensitivity Analysis of Cross-Country Growth Regressions," 


\footnotetext{
American Economic Review, vol. 82, no. 4, 942-63

11. Willem Adema, Maxime Labaique. Net social expenditure, 2005 edition. More comprehensive measure of social support / OECD Social, Employment and Migration Working Papers No. 29 [Електронний ресурс] Режим доступу http://www.oecd.org/dataoecd/56/2/ 35632106.pdf

12. Government at a Glance 2009 [Електронний pecypc] Режим доступу: http://statlinks.oecdcode.org/
}

422009151P1G006.XLS

13. OECD Factbook 2010: Economic, Environmental and Social Statistics [Електронний ресурс] Режим доступу http://www.oecd-ilibrary.org/docserver/ download/fulltext/302010061x1t009.xls?expire

14. Бюджет - 2011: Реалістичні показники на 2011 рік. [Електронний ресурс] Режим доступу http:// www.ier.com.ua

\section{Аннотация \\ РОЛЬ ГОСУДАРСТВА В СОЦИАЛИЗАЦИИ ЭКОНОМКИ: ФИНАНСОВЫЙ АСПЕКТ}

Елена Третьякова, Марина Онопко

Рассматривается роль правительства в обеспечении социальной защиты населения $и$ возможности повышения эффективности регулирования. Основываясь на опыте стран ОЭСР и Европейского Союза, очениваются направления изменения подходов к социальному обеспечению и его финансированию, а также влияние модели социального обеспечения на экономический рост и человеческое развитие и возможности их применения в Украине.

Ключевые слова: государство, сочиальные издержки, государство всеобщего благосостояния, соииальное рыночное хозяйство.

\section{Summary}

Elena Tretyakova, Marina Onopko

\section{THE STATE'S ROLE IN THE SOCIALIZATION OF THE HOUSEKEEPER: THE FINANCIAL ASPECT}

The role of the government in social protection of citizens and ways to increase its effectiveness of the policies are determined. The approaches to the social defense in OECD and European Union are evaluated and ways to improve existing model and finincing in Ukraine are defined. The impact of the social defense model on economic growth and human development is reviewed.

Key words: state, social expenditures, welfare state, social market economy. 
УДК 336.5.02

(C) Свердан М.M., 2011

Міжсгалузевий інститут управління, м.Київ

\section{БЮДЖЕТНІ ВИДАТКИ: МЕХАНІЗМ ФУНКЦІОНУВАННЯ ТА ХАРАКТЕР РЕАЛІЗАЦЇ̈ В ПЕРЕРОЗПОДІЛІ СУСПІЛЬНИХ ДОХОДІВ}

Дослідження демонструє фінансовий характер реалізаиії бюджетних видатків держави. Відображено сучасний стан бюджету держави та його потениійні можливості у фінансуванні видатків. Охарактеризовано основні тендениії бюджетних видатків. Розкрито основні недоліки та проблеми здійснення бюджетних видатків. Визначено напрями оптимізації, удосконалення та диверсифікаиії бюджетних видатків держави.

Ключові слова: державні фінанси, бюджет, бюджетна система, бюджетні видатки, бюджетні доходи, фінансування бюджетних видатків

Фінансова система країни в сучасних умовах досить масштабна у структурному відношенні та функціонально різнопланова і всеохоплююча, забезпечуючи процес суспільного відтворення. Кожна складова фінансової системи покликана виконувати обсяг властивих їй конкретних завдань. Чільне місце у фінансовій системі займають державні фінанси.

Державні фінанси як вагомий елемент єдиної загальної фінансової системи країни $\epsilon$ інструментом мобілізації коштів усіх секторів національного господарства для проведення збалансованої політики у контексті забезпечення умов сталого соціально-економічного розвитку суспільства. Державні фінанси покликані забезпечити перерозподіл грошових ресурсів між різними секторами економіки, соціальними групами та регіонами тощо, будучи найважливішим засобом структурної перебудови економіки, реалізації цільових соціальноекономічних програм. Масштаби перерозподілу фінансових ресурсів багато в чому залежать від рівня розвитку та стану економіки, ступеня участі держави в економічному житті суспільства.

Функція сектора державних фінансів кардинально протилежна функціям інших секторів економіки, суть якої полягає в наданні неринкових послуг окремим верствам населення чи окремим громадянам, суспільству загалом, а також у перерозподілі доходів, власності і багатства. 3 допомогою відповідних фінансових важелів держава здатна активно впливати на темпи й напрями господарського розвитку суспільства, володіючи майже необмежними потенційними фінансовими можливостями у контексті регулювання економіки, стимулювання економічного зростання, управління соціальноекономічними процесами, проведення політики соціального маневрування. Ринкова система дуже нерівномірно розподіляє грошові доходи, а отже, $\mathrm{i}$ національний продукт країни загалом. Важливим завданням держави $€$ відносне вирівнювання доходів окремих груп населення за допомогою субсидій або споживачам, або виробникам. Відповідна модель кругообігу доходів і видатків за участю державного сектора показує, в якій мірі держава виконує функції перерозподілу доходів і ресурсів, стабілізації національної економіки й утвердженню соціальної гармонії в суспільстві.

Держава та фінансове забезпечення їі діяльності повинні забезпечувати, насамперед, потреби у громадських благах. Конкурентна ринкова система часто спонукає до виготовлення продукції, яка не відповідає суспільним потребам. Тож держава покладає на себе функції їх фінансування та виробництва. Кошти, що перерозподіляються державою через систему іiі фондів, спрямовуються на фінансування видатків 3 метою задоволення суспільних потреб загальнодержавного характеру, які не можуть бути реалізовані за рахунок приватного підприємництва та приватного капіталу.

Істотною рисою, що відрізняе економічні системи світу одна від одної, $\epsilon$ співвідношення ролі держави та ринку в управлінні соціальноекономічними процесами. Економічні функції держави надзвичайно різноманітні і спрямовані, як правило, на підтримку й полегшення функціонування ринкової системи, а також на посилення та модифікацію функціонування ринкових відносин.

Вагомим наслідком функціонування чисто ринкової економіки є суттєва диференціація доходів окремих соціальних груп населення. Ринкова система забезпечує значні доходи для тих, чия праця високо оплачується (на підставі природних здібностей, здобутої освіти і майстерності; такі ж доходи одержують й ті, хто володіє великим капіталом, природними ресурсами тощо, заробленими наполегливою працею чи 
отриманими у спадок). Інші категорії населення (які мають менші здібності, отримали скромну освіту і кваліфікацію, не заощадили чи не дістали у спадщину жодних матеріальних засобів), одержують доволі скромні доходи, а окремі групи населення заробляють дуже мало чи аналогічно безробітним і зовсім не мають доходів. Отже, важливим завданням держави є зниження ступеня нерівності у доходах окремих верств населення, що особливо передбачає перерозподіл доходів на користь осіб, які мають мізерний дохід чи не мають його зовсім. Також держава впливає на розподіл доходів шляхом ринкового втручання за допомогою регулювання ринкових цін: гарантовані ціни та мінімальні ставки заробітної плати є наглядними прикладами того, як держава фіксує ціни $з$ метою підвищення доходів певних груп населення. Хоча чинне національне законодавство не дозволяє державі активно впливати на процеси матеріального розшарування населення та зменшення диференціації в суспільних доходах.

Державний фінансовий сектор - домінуюча компонента єдиного соціально-економічного середовища й системи суспільних взаємовідносин. У його рамках бюджет $є$ основним підгрунтям фінансово-економічного життя держави, запорукою піi фінансової дієздатності та невід'ємною передумовою підвищення благоустрою населення. Отже, бюджет держави є категорією багатоаспектного й масштабного прикладного застосування, спроможної всецільно впливати на різні сторони соціально-економічного розвитку суспільства. У великій мірі всі зазначені позиції реалізуються через фіскальну політику держави на макроекономічному рівні.

Бюджет держави займає центральне місце в системі фінансових методів регулювання розвитку економіки й управління суспільством. Якщо ринкова економіка грунтується на позиції саморегулювання, в чому полягає іiі основна перевага, автономно здійснюючи вплив на розвиток окремих галузей, регіонів і підприємств, виробництво певних товарів і сферу послуг, то державний фінансово-бюджетний механізм $€$ цілеспрямованим плановим інструментом перерозподілу суспільних доходів у інтересах збалансованого забезпечення загальнодержавних соціально-економічних потреб. Ринкова саморегулівна система базується на критерії ефективності, що забезпечує об'єктивне підгрунтя розвитку економіки і соціальної сфери, а не суб'єктивну мотивацію. Бюджетний механізм держави як засіб перерозподілу суспільних доходів спроможний ефективно коригувати i спрямовувати ринкові сили на досягнення певних цілей та реалізацію встановлених завдань. Тобто, бюджет держави не є замінником саморегулівної дії ринкових відносин, а лише доповнює ії в тих напрямах, де мають місцепевні прогалини і вузькі місця. При цьому бюджет держави в умовах планової економіки відіграє пасивну роль, оскільки на нього покладається функція фінансового забезпечення реалізації плану економічного та соціального розвитку, де він $є$ похідним від плану. Натомість, в умовах ринкових відносин фінансові інструменти та важелі впливу, які становлять основу фінансового механізму держави, обумовлюють інтенсифікацію форм державного регулювання економіки, грунтуючись на активному застосуванні економічних методів управління, чим пояснюється роль державних фінансів у суспільстві. Фінансовий механізм являє собою сукупність фінансових методів і форм впливу держави на розвиток суспільства. Бюджетний вплив є складовою цього механізму.

У наукових дослідженнях бюджет держави завжди займає одну з провідних позицій. Можна виділити такі основні блоки фінансово-бюджетної діяльності держави:

організація бюджетної системи держави, визначення загальних засад іiі функціонування; організація бюджетного процесу та його управління; установлення домінант бюджетної політики;

визначення й обгрунтування фінансових важелів та інструментів бюджетної політики; закріплення базових джерел дохідної частини бюджету держави;

затвердження головних напрямів здійснення бюджетних видатків; організація системи міжбюджетних відносин.

Усі перелічені компоненти дуже тісно взаємопов'язані між собою, взаємовпливові та взаємозалежні, оскільки в сукупності визначають характер фінансово-бюджетної діяльності держави та їі ефективність [2]. Повноцінна бюджетна функціональність держави можлива не лише в умовах стабільності економічного становища, але й потребує прискорення темпів економічного зростання. При цьому очевидна $\epsilon$ взаємна залежність. Масштабність бюджетної діяльності держави залежить від стану економіки, що зумовлює можливості перерозподілу суспільних доходів. Водночас бюджет держави може виступати активним і досить потужним засобом інтенсифікації процесів економічного зростання [1]. А стан економіки і темпи економічного зростання впливають на можливості формування дохідної частини бюджету, визначаючи рівень мобілізації певної 
Свердан М. М.

частини суспільного продукту 3 метою фінансового забезпечення бюджетних видатків [4]. Нарешті, ключову позицію займають бюджетні видатки держави як ефект і наслідок реалізації системи перерозподільних відносин в суспільстві [7]. Важливе значення має в цьому контексті як фінансування, насамперед, соціальної сфери [6], так і забезпечення подальших процесів економічного зростання шляхом спрямування відповідних обсягів фінансових ресурсів в економіку [5]. Вказані напрями реалізації бюджетних видатків $є$ неподільними, оскільки виступають рівнозначними компонентами єдиного процесу суспільного відтворення [10]. Загальні ж пріоритети фінансово-бюджетної діяльності держави втілюють відповідно до формулювань державної бюджетної політики [3].

Виходячи 3 мети фінансової організації бюджету - перерозподіл суспільних доходів найбільш важливе значення має кінцевий результат: реалізація бюджетних видатків. Державні видатки відображають напрями й цілі бюджетних асигнувань і демонструють їх суспільну ефективність - як у соціальному, так і в економічному відношеннях. Зважаючи на окреслену актуальність, проблематичність i складність завдань фінансово-бюджетної діяльності держави питання бюджетних видатків потребує постійних наукових досліджень. Пропоноване дослідження є черговою спробою виявлення стану реалізації та тенденцій подальшого розвитку бюджетних видатків держави.

Бюджет забезпечує розвиток економіки та життєдіяльність держави. Формування економічних відносин в умовах ринку потребують підвищення ролі бюджету держави як системи перерозподілу валового внутрішнього продукту. Бюджет одночасно виконує функції формування фінансових ресурсів держави та реалізації системи перерозподільних відносин в інтересах суспільства відповідно до його потреб.

Рівень фінансування бюджетних видатків залежить насамперед від міри наповнення дохідної частини бюджету держави. Істотний розрив між цими двома частинами провокує до суттєвих збоїв як фінансовій діяльності держави, так і в функціонуванні соціальної та економічної сфер суспільства (табл. 1).

Баланс Зведеного бюджету України в 1995-2009 рр.*

\begin{tabular}{|c|c|c|c|c|c|c|c|}
\hline Рік & \multirow{2}{*}{ Доходи, } & Видатки, & \multicolumn{2}{|c|}{ Дефіцит / Профіцит } & \multicolumn{3}{|c|}{ У відсотках до ВВП } \\
\cline { 5 - 8 } & млрд. грн. & млрд. грн. & млрд. грн. & \% & доходи & видатки & $+/-$ \\
\hline 1995 & 20,7 & 24,3 & $-3,6$ & $-17,4$ & 38,0 & 44,6 & 6,6 \\
\hline 1996 & 30,2 & 34,2 & $-4,0$ & $-13,2$ & 37,0 & 41,9 & 4,9 \\
\hline 1997 & 28,1 & 34,3 & $-6,2$ & $-22,1$ & 30,1 & 36,7 & 6,6 \\
\hline 1998 & 28,9 & 31,2 & $-2,3$ & $-8,0$ & 28,2 & 30,4 & 2,2 \\
\hline 1999 & 32,9 & 34,8 & $-1,9$ & $-5,8$ & 25,2 & 26,7 & 1,5 \\
\hline 2000 & 49,1 & 48,1 & 1,0 & 2,1 & 28,9 & 28,3 & $-0,6$ \\
\hline 2001 & 54,9 & 55,5 & $-0,6$ & $-1,1$ & 26,9 & 27,2 & 0,3 \\
\hline 2002 & 61,9 & 60,3 & 1,6 & 2,7 & 27,4 & 26,7 & $-0,7$ \\
\hline 2003 & 75,3 & 75,8 & $-0,5$ & $-1,0$ & 28,2 & 28,4 & 0,2 \\
\hline 2004 & 91,5 & 102,5 & $-11,0$ & $-12,0$ & 26,5 & 29,71 & 3,2 \\
\hline 2005 & 134,2 & 142,0 & $-7,8$ & $-5,8$ & 30,4 & 32,21 & 1,8 \\
\hline 2006 & 171,8 & 175,5 & $-3,7$ & $-2,15$ & 31,6 & 32,31 & 0,7 \\
\hline 2007 & 219,9 & 227,6 & $-7,7$ & $-3,5$ & 30,5 & 31,61 & 1,1 \\
\hline 2008 & 297,9 & 312,0 & $-14,1$ & $-4,7$ & 31,4 & 32,91 & 1,5 \\
\hline 2009 & 273,0 & 310,2 & $-37,2$ & $-13,6$ & 29,8 & 33,9 & 4,1 \\
\hline
\end{tabular}

*Складено та розраховано на основі даних Державного комітету статистики України

Як правило, традиційно простежується тенденція перевищення видатків над доходами бюджету, внаслідок чого утворюється бюджетний дефіцит держави. Указаний факт мотивує або загальне скорочення бюджетних видатків (що можливе також із запровадженням секвестру), або ж пошук державою альтернативних джерел грошових коштів для повноцінного фінансування видаткової частини бюджету (зазвичай, використовується механізм державних запозичень). Як показують офіційні статистичні дані, бюджетний дефіцит за період 1995-2009 pр. майже завжди, за винятком 2000 p. і 2002 р., мав місце, а за підсумком 2009 бюджетного року досягнув пікової точки - максимальної поділки на рівні 37,2 млрд. грн. (що 13,6\% у відсотковому 
вираженні є значно меншим порівняно із 1997 р. $22,1 \%$, але всього 6,2 млрд. грн.).

У першу чергу необхідно віддзначити різкий спад доходів бюджету держави (рис. 1), а також прослідкувати залежність фінансово-бюджетної діяльності держави від темпів виробництва валового внутрішнього продукту країни.

\section{$\square$ Доходи $\square$ Видатки}

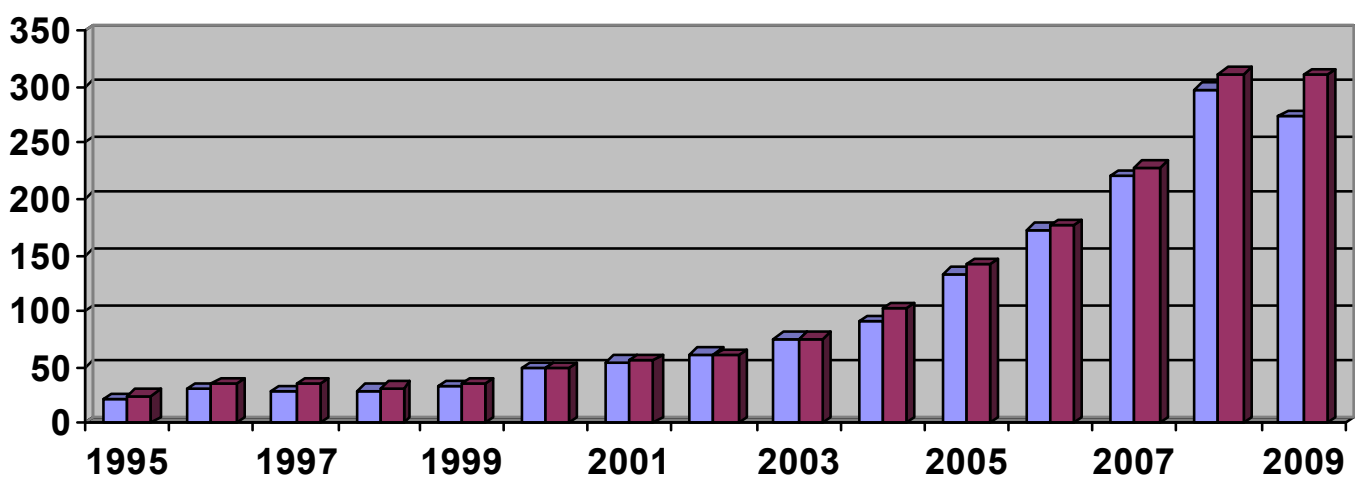

Рис. 1. Динаміка доходів і видатків Зведеного бюджету України

Зменшення бюджетів доходів за 2008-2009 pр. становить 24,9 млрд. грн. (невластива тенденція для бюджету; аналогічна ситуація мала місце тільки в 1997 р. на 2,1 млрд. грн.), хоча скорочення бюджетних видатків відбулося лише на 1,8 млрд. грн., що пояснюється залученням у досить вагомих обсягах альтернативних джерел фінансових ресурсів. Указана ситуація більш ніж дивовижна, оскільки в 2007-2008 рр. мало місце неймовірне підвищення бюджетних доходів: 78 млрд. грн. (35,5\%). Різке зниження доходів бюджету держави в 2009 р. можна пояснити загальним станом фінансово-економічної кризи, що й справило значний вплив на зайнятість населення та рівень доходів платників податків. Ця ж криза 2008-2009 рр. позначилася на обсягах i темпах виробництва валового внутрішнього продукту, адже саме він $\epsilon$ джерелом мобілізації коштів у бюджеті для фінансування державних видатків (табл. 2).

\section{Динаміка валового внутрішнього продукту та видатків Зведеного бюджету України в 1995-2009 рр.* (млрд. грн.)}

\begin{tabular}{|c|c|c|c|c|c|c|c|}
\hline \multirow[t]{2}{*}{ Рік } & \multirow[t]{2}{*}{ ВВ П } & \multirow[t]{2}{*}{$\begin{array}{c}\text { Бюджетні } \\
\text { ви датки }\end{array}$} & \multicolumn{2}{|c|}{$\begin{array}{c}\text { Темпи зростання } \\
\text { ВВП }\end{array}$} & \multicolumn{2}{|c|}{$\begin{array}{c}\text { Темпи зростання } \\
\text { бюджетних } \\
\text { видатків } \\
\end{array}$} & \multirow[t]{2}{*}{$\begin{array}{c}\text { Різниця між темпами } \\
\text { зростання ВВП та } \\
\text { бюджетними видатками }\end{array}$} \\
\hline & & & млрд. грн. & $\%$ & млрд. грн. & $\%$ & \\
\hline 1995 & - & 24,3 & - & - & - & - & - \\
\hline 1996 & 81,5 & 34,2 & - & - & 9,9 & 40,7 & - \\
\hline 1997 & 93,4 & 34,3 & 11,9 & 14,6 & 0,1 & 0,3 & 14,9 \\
\hline 1998 & 102,6 & 31,2 & 9,2 & 9,9 & $-3,1$ & $-9,0$ & 18,9 \\
\hline 1999 & 130,4 & 34,8 & 27,8 & 27,2 & 3,6 & 11,5 & 15,7 \\
\hline 2000 & 170,1 & 48,1 & 39,7 & 30,4 & 13,3 & 38,2 & $-7,8$ \\
\hline 2001 & 204,2 & 55,5 & 34,1 & 20,1 & 7,4 & 15,4 & 4,7 \\
\hline 2002 & 225,8 & 60,3 & 19,6 & 10,6 & 4,8 & 8,6 & 2,0 \\
\hline 2003 & 267,3 & 75,8 & 41,5 & 18,4 & 15,5 & 25,7 & $-7,3$ \\
\hline 2004 & 345,1 & 102,5 & 77,8 & 29,1 & 26,7 & 35,2 & $-6,1$ \\
\hline 2005 & 441,5 & 142,0 & 96,4 & 27,9 & 41,5 & 38,5 & $-10,6$ \\
\hline 2006 & 544,15 & 175,5 & 102,65 & 23,3 & 33,5 & 23,6 & $-0,3$ \\
\hline 2007 & 720,7 & 227,6 & 176,55 & 32,5 & 52,1 & 29,7 & 2,8 \\
\hline 2008 & 948,1 & 312,0 & 227,4 & 31,5 & 84,4 & 37,1 & $-5,6$ \\
\hline 2009 & 913,35 & 310,2 & $-34,75$ & $-3,7$ & $-1,8$ & $-0,6$ & $-3,1$ \\
\hline
\end{tabular}

*Складено та розраховано за даними Державного комітету статистики України 


\section{Свердан М. М.}

Фактично, 2009 р. - єдиний, коли має місце спад валового внутрішнього продукту. Хоча, у порівнянні з темпами його зростання, темпи зростання бюджетних видатків знизились значно менше. Указана ситуація вказує на ту потребу, зокрема, що необхідна переорієнтація бюджетної політики держави по відношенню до стимулювання процесу суспільного відтворення відновлення, стабілізації й нарощування обсягів і темпів виробництва валового внутрішнього продукту. Зазначене вимагає зміни статусу економічної ролі держави, іï місця у процесі суспільного відтворення та, особливо, трансформації бюджетних форм і методів впливу на економіку. Необхідно посилити значення таких фінансових важелів, як бюджетні інвестиції, бюджетні позики, бюджетні трансферти (суб'єктам господарювання - субсидії).

Економічному зростанню треба приділити підвищену увагу в сучасних умовах, оскільки саме від нього безпосередньо залежить фінансова діяльність держави та міра ii втручання в соціально-економічні процеси через бюджетні видатки. У джерелах відзначається: "Протягом понад століття відбувається зростання національного доходу та виробництва. Водночас майже у всіх країнах спостерігається тенденція до ще більшого зростання державних затрат" [9, c. 126]. Тенденція - це орієнтир, але ще не факт, що видно 3 вищенаведеної ситуації, яка характеризується різноманітними фінансовими перекосами. Безумовно, потреби суспільства зростають; відповідно, необхідне й реальне зростання валового внутрішнього продукту й національного доходу i, внаслідок цього, збільшення бюджетних видатків держави на соціальні та економічні цілі заради забезпечення й стимулювання суспільного прогресу. Адже: "Лише зростаюча економіка може збільшити рівень задоволення необмежених потреб і розв'язати соціально-економічні проблеми ... Економічне зростання дозволяє здійснювати нові програми 3 питань боротьби 3 бідністю і забрудненням навколишнього середовища без падіння існуючого рівня споживання, скорочення обсягів інвестицій і виробництва суспільних благ. Економічне зростання полегшує вирішення проблеми обмеженості ресурсів" [8, с. 7].

Дефіцитність фінансових ресурсів у бюджеті держави істотно знижує як фінансування поточних соціально-економічних потреб суспільства, так i не дозволяє втілити фінансово-інвестиційні програми державного рівня щодо інтенсифікації процесу економічного зростання в загальному масштабі країни. Враховуючи все більше наростаючу схильність бюджетних видатків держави до фінансування соціальної сфери і соціальних потреб суспільства, економічна сторона фінансової діяльності держави залишається осторонь. Тобто статус "соціально зорієнтованої економіки" - своєрідний ідеал держави, але не абсолютний показник ії фінансової діяльності. Домінування виключно сфери соціального забезпечення суспільства через механізм бюджетних видатків загрожує дефектами економічного характеру. Більше того, значна частина фінансових ресурсів бюджету спрямовується державою на інші цілі соціального характеру; зокрема, це стосується державних цільових позабюджетних фондів, а найбільше Пенсійного фонду України, дохідна частина якого на 1/3 формується за рахунок бюджетних коштів держави. Через це, необхідність фінансового підкріплення державою видаткової частини позабюджетних фондів соціального призначення істотно обмежує, водночас, міру фінансування бюджетом поточних статей соціального характеру. У загальній структурі, домінування бюджетних видатків на соціальну сферу є явним (табл. 3). А кризовий стан державних фінансів очевидний у комплексному масштабі.

Тільки в 1994 р. видатки на економічну діяльність переважали: 40,6\% проти 39,1\% соціальних видатків (на соціальний захист населення, соціальне забезпечення та соціальну сферу). У числі бюджетних видатків фінансуються також дотації (трансферти) домогосподарствам для підвищення купівельної спроможності, що має назву "ін'єкцій купівельної спроможності в економіку". Якщо в бюджеті держави виявляється надлишок (тобто, вилучається більше за допомогою податків, ніж віддається), тоді вилучення із макроекономічного обороту перевищують "ін'єкції", а в результаті відбувається скорочення національного продукту (національного доходу). При наявності дефіциту такі "ін'єкції" більші, ніж вилучення. Це означає, що купівельна спроможність зростає, а національний продукт і національний доход збільшуються. Відзначимо, що ці стандартні підходи, необхідні для функціонування ринкової системи, непридатні для тієї виняткової ситуації, яка утворилася ще в 1990-х рр. у національній економіці, коли зростання бюджетних видатків держави призвело не лише до поглиблення кризи фінансової та кредитно-грошової систем, але й спричинило різке скорочення обсягів виробництва. Тому дуже важливо, щоби ця ж ситуація не повторилася через десяток - півтора десятка років згодом у сучасних мовах.

Бюджет держави - основна компонента державних фінансів, завдяки якій реалізується переважна частина системи об'єктивно обумовлених розподільчих відносин, що виконують призначення задоволення потреб у фінансових ресурсах суспільства в цілому, Бюджет 
Динаміка видатків Зведеного бюджету України * (млрд.грн.)

\begin{tabular}{|c|l|c|c|c|c|c|c|c|c|}
\hline № & \multicolumn{1}{|c|}{ Показник } & $\mathbf{2 0 0 2}$ & $\mathbf{2 0 0 3}$ & $\mathbf{2 0 0 4}$ & $\mathbf{2 0 0 5}$ & $\mathbf{2 0 0 6}$ & $\mathbf{2 0 0 7}$ & $\mathbf{2 0 0 8}$ & $\mathbf{2 0 0 9}$ \\
\hline 1. & $\begin{array}{l}\text { Видатки зведеного } \\
\text { бюджету, всього }\end{array}$ & 60,3 & 75,8 & 102,5 & 142,0 & 175,5 & 227,6 & 312,0 & 310,2 \\
\hline 2. & $\begin{array}{l}\text { Загальнодержавні } \\
\text { функції }\end{array}$ & 8,6 & 10,0 & 12,3 & 15,5 & 19,9 & 24,3 & 30,8 & 33,2 \\
\hline 3. & Оборона & 3,5 & 5,3 & 6,2 & 6,0 & 6,4 & 9,4 & 11,7 & 9,7 \\
\hline 4. & $\begin{array}{l}\text { Громадський } \\
\text { порядок, безпека та } \\
\text { судова влада }\end{array}$ & 5,0 & 5,8 & 7,9 & 10,2 & 12,7 & 18,5 & 27,1 & 24,3 \\
\hline 5. & $\begin{array}{l}\text { Економічна } \\
\text { діяльність }\end{array}$ & 7,2 & 12,2 & 18,7 & 19,1 & 27,3 & 40,5 & 51,3 & 39,7 \\
\hline 6. & $\begin{array}{l}\text { Охорона природного } \\
\text { навколишнього } \\
\text { середовища }\end{array}$ & 0,7 & 0,9 & 1,2 & 1,25 & 1,6 & 2,2 & 2,8 & 2,5 \\
\hline 7. & $\begin{array}{l}\text { Житлово- } \\
\text { комунальне } \\
\text { господарство }\end{array}$ & 1,4 & 1,8 & 2,7 & 3,9 & 8,0 & 5,9 & 9,0 & 7,5 \\
\hline 8. & Охорона здоров’я & 7,5 & 9,7 & 12,2 & 15,5 & 19,7 & 26,7 & 33,6 & 36,6 \\
\hline 9. & $\begin{array}{l}\text { Духовний та } \\
\text { фізичний розвиток }\end{array}$ & 1,4 & 2,05 & 2,7 & 3,5 & 4,3 & 5,7 & 8,0 & 8,3 \\
\hline 10. & Освіта & 12,3 & 15,0 & 18,3 & 26,8 & 33,8 & 44,3 & 61,0 & 66,8 \\
\hline 11. & $\begin{array}{l}\text { Соціальний захист і } \\
\text { соціальне } \\
\text { забезпечення }\end{array}$ & 12,6 & 13,0 & 19,3 & 34,0 & 41,4 & 48,5 & 74,1 & 78,8 \\
\hline
\end{tabular}

*Складено та розраховано на основі даних Державного комітету статистики України

$\epsilon$ найважливішим елементом системи фінансового управління економікою, внаслідок чого його збалансованість і оптимальність - важливі чинники економічного зростання. Співрозмірність i адекватність мобілізації фінансових ресурсів у сукупності з напрямами й методами їх витрачання використання відповідно до реальних обсягів суспільних потреб соціального й економічного характеру забезпечують умови для виконання державою суспільно необхідних завдань і функцій, істотно впливаючи на досягнення стратегічних цілей державного управління.

\section{Список літератури}

1. Запатріна I.В. Бюджетний механізм економічного зростання / I.В. Запатріна. - К.: Ін-т соц.-екон. стратегій, 2007. - 528 с.

2. Луніна I.О. Державні фінанси та реформування міжбюджетних відносин: Монографія / І.О. Луніна. К.: Наукова думка, 2006. - 432 с.

3. Лютий I.О. Теоретико-методологічні засади бюджетної політики держави / I.О. Лютий // Фінанси України. - 2009. - №12. - С. 13-19.

4. Огонь Ц.Г. Доходи бюджету України: теорія та практика: Монографія / Ц.Г. Огонь. - К.: КНТЕУ, 2003.
$-580 \mathrm{c}$.

5. Піхоцький В.Ф. Ефективність бюджетної політики як інструмент соціально-економічного розвитку України / В.Ф. Піхоцький // Фінанси України. - 2010. №3. - С. 30-37.

6. Полозенко Д.В. Особливості механізму фінансування соціальних послуг в Україні / Д.В. Полотенко, Н.О. Квітко // Фінанси України. - 2010. №4. - С. 45-52.

7. Розпутенко I. Державні видатки в перехідних економіках / І. Розпутенко. - К.: Видавництво АУДУ. 1998. - $242 \mathrm{c}$.

8. Розпутенко I. Економічне зростання в Україні: проблеми і здобутки / І. Розпутенко. - К.: К.І.С., 2001. $-136 \mathrm{c}$.

9. Самуельсон П. Економіка: Підручник / П. Самуельсон. - Львів: Світ, 1993. - 495 с.

10. Свердан М.М. Державні фінанси в Україні: стан, тенденції розвитку та перспективи реформування / Матеріали міжнародної проблемно-наукової міжгалузевої конференції "Інформаційні проблеми комп'ютерних систем, юриспруденції, енергетики, економіки, моделювання та управління (ПНМК 2010)" // Поступ в науку. Збірник наукових праць Бучацького інституту менеджменту і аудиту. - №6. Т. 1. - Бучач. - 2010. - С. 145-149. 
Свердан М. М.

\section{БЮДЖЕТНЫЕ РАСХОДЫ: МЕХАНИЗМ ФУНКЦИОНИРОВАНИЯ И ХАРАКТЕР РЕАЛИЗАЦИИ В ПЕРЕРАСПРЕДЕЛЕНИИ ОБЩЕСТВЕННЫХ ДОХОДОВ}

Исследование демонстрирует финансовый характер реализации бюджетных расходов государства. Отображено современное состояние бюджета государства и его потенциальные возможности в финансировании расходов. Охарактеризованы основные тендениии бюджетных расходов. Раскрыто главные недостатки и проблемы осуществления бюджетных расходов. Определены направления оптимизациии, усовериенствования и диверсификац̧ии бюджетных расходов государства.

Ключевые слова: государственные финансы, бюджет, бюджетная система, бюджетные расходы, бюджетные доходы, финансирование бюджетных расходов

\section{Summary}

Michael Sverdan

\section{BUDGET EXPENDITURES: FUNCTION MECHANISM AND REALIZATION CHARACTER IN THE REDISTRIBUTION OF PUBLIC REVENUES}

Present investigation paper demonstrates the financial realization character of the state budget expenses. The modern condition of the state budget and its potential possibilities for expenses financing are reflected. Main tendencies of budget expenses are characterized. Main shortcomings and problems of budget expenses making are shown. The directions for state budget expenses optimization, improvement and diversification are appointed.

Key words: public finance, budget, budget system, budget expenditures, budget revenues, financing of budget expenses. 
УДК 336.717.18 (477)

(C) Коцабюк Р.Г., 2011

Чернівецький національний університет ім. Юрія Федьковича, м. Чернівці

\section{УПРАВЛІННЯ ВЛАСНИМ КАПІТАЛОМ БАНКУ В УКРАЇНІ}

Розроблено рекомендації щодо вдосконалення управління джерелами нарощування власного капіталу банків $i$ забезпечення його достатності за умов фінансової кризи в Украйні. Визначено методологічні підходи до вибору внутрішніх і зовнішніх джерел підвищення рівня капіталізачіі банків; дано очінку наслідків внесення змін в умовах фінансової кризи в нормативно-законодавче регулювання достатністю капіталу банків; викладено погляд авторів на залучення коштів іноземних інвесторів і держави до статутних капіталів проблемних вітчизняних банків.

Ключові слова: нерозподілений прибуток, переоцінка основних засобів, розкриті резерви, емісійний дохід, додаткова емісія акиій, субординований борг, бонусна емісія.

Сучасний стан банківської системи України характеризується значним погіршенням фінансових результатів діяльності банків, наявністю банківських установ, що знаходяться на межі банкрутства чи перебувають у стадії ліквідації, значними обсягами неякісних активів, передусім проблемних кредитів. Так, за результатами діяльності в 2009 р. банківська система країни зазнала збитків на суму 38.450 млрд. грн.. Від'ємними є результати їі діяльності в нинішньому році. За перше півріччя фінансовий результат діяльності банків становив (-) 8.306 млрд. грн. Упродовж 2009 р. шість банків припинили діяльність, три було націоналізовано. У першому півріччі 2010 p. із Державного реєстру виключено ще три банки (два - у зв'язку 3 ліквідацією, один - з реорганізацією); у семи банків відкликано ліцензії на здійснення всіх банківських операцій. За станом на 01.07.2010 р. у стадії ліквідації перебувало 18 банків. На 03.08.2010 p. у чотирьох банках запроваджено тимчасову адміністрацію [1]. За нашими розрахунками, упродовж 2009 року частка проблемних кредитів у кредитному портфелі банків збільшилася в 3,88 разу і становила 9,36\%, а за станом на 01.03 .2010 р. недіючі кредити дорівнювали 102,918 млрд. грн.., або 13,74\% від валових кредитів банківської системи країни [1], що дає підстави говорити про кризовий стан її кредитної діяльності. На 01.03.2010 p. на кожну гривню власного капіталу банків припадало 0,29 грн. недіючих кредитів не покритих резервом під кредитні ризики [1].

За таких умов наявність власного капіталу, адекватного обсягам і структурі активів і пасивів банків, набуває особливої актуальності.

Як свідчать дані НБУ, власний капітал в Україні на 01.01.2010 р. становив 115,175 млрд. грн. За 6 місяців поточного року його розміри дещо збільшилися - на 11,387 млрд. грн. За цей період поліпшився показник середнього розміру власного капіталу в обчисленні на один діючий банк. За нашими розрахунками, він зріс із 0,633 млрд. грн. (близько 0,073 млрд. грн. доларів США) на 01.01.2010 р. до 0,748 млрд. грн. (0,092 млрд. доларів США) на 01.07.2010 р., але перебуває на значно нижчому рівні, ніж відповідні показники в країнах із розвиненою ринковою економікою. Незначні і розміри власного капіталу відносно активів банків. Співвідношення між ними на 01.01.2010 p. становило 0,142, на 01.03.2010 p. 0,145 [1]. Проте норматив адекватності регулятивного капіталу банків упродовж цього періоду, за нашими розрахунками, перевищував мінімально допустимий його рівень відповідно в 1,81 разу та в 2,06 разу, а норматив співвідношення регулятивного капіталу до сукупних активів - в 1,54 разу та в 1,62 разу. Не винятковими є випадки, коли банки, щодо яких застосовано процедуру запровадження тимчасової адміністрації, виконували нормативи достатності регулятивного капіталу, що свідчить про недосконалість методики розрахунку цих нормативів регулювання банківської діяльності.

Отже, є всі підстави стверджувати, що проблема управління власним капіталом банків в Україні актуальна й потребує подальших наукових досліджень і практичних рішень.

Теоретичні й практичні аспекти управління власним капіталом банку висвітлено в працях багатьох відомих учених, зокрема: А.Герасимовича, Н.Думаса, А.Косого,

О.Лаврушина, І.Лаврушина, Л.Примостки, Роуза Пітера та інших. Однак, незважаючи на значні результати наукових досліджень, не вирішеними залишаються питання щодо вибору джерел нарощування власного капіталу банків та участі держави в рекапіталізації проблемних банків. Неповно висвітлено зміни в нормативнозаконодавчій базі, що регулює джерела формування власного капіталу, та їх вплив на 
забезпечення достатності цього капіталу.

Вирішення проблеми забезпечення достатності власного капіталу банку потребує наявності джерел його нарощування, всю сукупність яких слід об'єднати у дві групи:

1) внутрішні джерела (нерозподілений прибуток, переоцінка основних засобів, розкриті резерви);

2) зовнішні джерела (додаткова емісія акцій, субординований борг, емісійний дохід, бонусна емісія).

Вибір "кращого" джерела нарощування розмірів власного капіталу банку слід здійснювати 3 урахуванням:

1) прав та інтересів існуючих і потенційних акціонерів банку;

2) ринкових умов (здатності ринку поглинути нову емісію акцій або капітальних зобов'язань банку);

3) ступеня точності прогнозів щодо майбутнього прибутку банку;

4) ризику недостатності або недоступності для банку окремого джерела власного капіталу;

5) відносних витрат щодо залучення певного джерела зростання власного капіталу;

6) впливу на прибутковість акціонерного капіталу, що вимірюється прибутком на одну звичайну акцію;

7) існуючих обмежень щодо залучення окремих джерел власного капіталу банку, передбачених законодавством i/aбо державними органами регулювання банківської діяльності;

8) оподаткування операцій 3 нарощування власного капіталу банку.

Основним внутрішнім джерелом нарощування власного капіталу банку $є$ його прибуток. Водночас нерозподілений прибуток як джерело нарощування капіталу банку оцінюється фахівцями неоднозначно, має як переваги, так i недоліки.

Перевагами є:

1) не залежить у засобах від ринку;

2) виключаються витрати на його залучення;

3) немає загрози втрати контрольного пакета акцій $і$ зниження розміру прибутку в розрахунку на одну акцію.

Недоліки:

1) збільшення податкових платежів у бюджет;

2) можливості банку щодо одержання прибутку в прогнозованих обсягах багато в чому залежать від факторів, що перебувають поза сферою його впливу.

Основні напрями реінвестування прибутку у власний капітал визначаються банком самостійно відповідно до внутрішніх нормативних документів, що регламентують процедуру розподілу прибутку. Однак окремі напрями використання прибутку як джерела збільшення капітальної бази банку передбачені на законодавчому рівні або нормативними актами НБУ.

Докризова практика формування резервів під кредитні ризики банку передбачала створення резерву під стандартну заборгованість (загальний резервний фонд) за рахунок прибутку, що залишався у банку після сплати податку на прибуток. Сума цього резерву зараховувалася у додатковий капітал банку, тоді як відповідно до стандартів Базеля-2 до капіталу другого рівня можуть частково зараховуватися загальні резерви за кредитними операціями банківської установи в розмірі не більше, ніж 1,25\% від зважених за ризиком активів. За цих обставин реальні показники достатності капіталу банків (норматив H2 і Н3) в Україні порівняно з міжнародною практикою значно завищувалися [6]. Різке погіршення стану кредитних вкладень банків в умовах фінансової кризи підвищило вимоги НБУ щодо формування резервів під кредитні операції банків. Відповідно до Закону України "Про внесення змін до деяких законів України з метою подолання фінансової кризи" від 23.06.209 р. № 1 533 загальний резерв під кредитні ризики банків із 01.11.2009 р. по 01.01.2011 р. відноситься на валові витрати банку. Більше того, до їх складу включається весь сформований резерв під позичкові активи, тоді як до прийняття цього закону до витрат відносився спеціальний резерв у сумі, що перевищувала $10 \%$ від кредитного портфеля банку.

Іншим обов'язковим напрямом використання прибутку для формування і нарощування власного капіталу є створення за рахунок відрахувань від прибутку резервного фонду банку, розмір якого обов'язково передбачається в установчих документах створюваного банку. Цей резерв призначений для покриття збитків і втрат, що виникають у результаті діяльності банку. Мінімальний розмір резервного фонду банку визначається його статусом. До прийняття Закону України "Про акціонерні товариства" його розмір не міг бути меншим, ніж $25 \%$ від статутного капіталу банку. Розмір щорічних відрахувань до резервного фонду повинен становити не менше $5 \%$ від чистого прибутку до досягнення ним мінімальної встановленої статусом величини. Отже, при збільшенні статутного фонду банк повинен наростити резервний фонд до необхідного розміру, що набуває особливої актуальності в сучасних умовах, коли банки активно нарощують свій статутний капітал, проте мають обмежені можливості для адекватного збільшення резервного фонду. Для банків, що утворюються, має значення те, що вимогами Закону України "Про акціонерні товариства" 
мінімальний розмір резервного фонду встановлено на рівні 15\% від статутного капіталу акціонерного товариства.

Використання прибутку як джерела нарощування власного капіталу банку багато в чому визначається його дивідендною політикою, співвідношенням прибутку, що залишається в розпорядженні банку, і прибутку, що розподіляється. У зв'язку з цим заслуговують на увагу методологічні підходи Пітера Роуза щодо управління достатністю капіталу за рахунок прибутку на основі оптимізації дивідендної політики [8].

Вони передбачають: за умов низького рівня утриманого прибутку уповільнюється зростання внутрішніх джерел власного капіталу; підвищується ризик банкрутства банку; стримується зростання його активів і, відповідно, доходів. Висока частка прибутку, що спрямовується на приріст власного капіталу, навпаки, призводить до зниження дивідендів акціонерам банку. Водночас зростання дивідендних виплат на акції викликає підвищення їх курсової вартості, що полегшує нарощування власного капіталу за рахунок такого зовнішнього джерела, як розміщення нового випуску акцій банку.

Зростання дивідендних виплат у цьому випадку виконує подвійну функцію:

1) збільшуються доходи наявних акціонерів;

2) полегшується нарощування власного капіталу за рахунок розміщення нової емісії.

Вирішальним фактором, що впливає на управлінське рішення банку про прийнятну частку утриманого прибутку і частку дивідендів у прибутку, є зростання активів. Банк не може допустити надмірного зниження співвідношення величини власного капіталу до суми активів. Тому необхідно розраховувати, як швидко повинен зростати прибуток банку, щоб забезпечити незмінним відношення власного капіталу до його активів. У цьому випадку як інструмент управління власним капіталом використовується коефіцієнт внутрішнього зростання (Кк), що відображає здатність банку самостійно нарощувати власний капітал.

Коефіцієнт внутрішнього зростання (Кк) розраховується за формулою:

\section{Кк $=$ ПНК * Кнак,}

звідси ПНК = Кк / Кнак; Кнак =КК / ПНК, де Кк - коефіцієнт внутрішнього зростання.

$\mathrm{K \kappa}=\mathrm{A} 1-\mathrm{A} 0 / \mathrm{A} 0$,

Де A1 i A0 - активи банку поточного й порівняльного періоду відповідно.

ПНК - прибуток на капітал.
ПНК = чистий прибуток (ЧП)/ власний капітал(ВК);

Кнак = коефіцієнт накопичення.

Кнак = нерозподілений прибуток(Пн)/ чистий прибуток (ЧП).

Для того, щоб банк збільшив власний капітал, йому треба збільшити або чистий прибуток, або частку утриманого прибутку, або і те й інше одночасно.

Якщо банк прагне поліпшити забезпеченість власним капіталом, він повинен зосередитися на скороченні витрат; підвищенні прибутковості; оптимізації фінансової й дивідендної політики. Управляючи власним капіталом, необхідно насамперед оцінити зазначені фактори, а потім визначати джерела нарощування рівня капіталізації. Банки, що розвиваються швидше, ніж це їм дозволяє норма внутрішнього зростання, повинні залучати капітал із зовнішніх джерел.

Для ухвалення управлінського рішення щодо використання внутрішніх джерел нарощування власного капіталу, менеджмент банку повинен керуватися певними положеннями. А саме:

1. Оскільки відповідно Закону України "Про акціонерні товариства"

акціонерний банк має спрямовувати на виплату дивідендів не менше 30\% чистого прибутку, він не може направляти весь чистий прибуток на приріст власного капіталу - незалежно від того, дорівнює прибутковість його капіталу запланованому приросту активів чи є нижчою. Водночас банк повинен залучити зовнішні джерела нарощування своєї капітальної бази;

2. Такої вимоги повинен дотримуватися банк ів тому випадку, коли прибуток на капітал менший від запланованого приросту активів (тобто Кк>ПНК) і банк не весь чистий прибуток спрямовує на збільшення власного капіталу.

Другим джерелом нарощування розмірів власного капіталу банку є переоцінка основних засобів. Необхідність переоцінки вкладень банку в основні засоби пов'язана 3 тим, що їх балансова вартість змінюється протягом усього терміну служби - від моменту придбання до моменту вибуття. Однак ринкова вартість одних основних засобів під впливом інфляційних процесів постійно збільшується , а інших - через особливості нарахування зношування й тривалості строку експлуатації, навпаки, зменшується. Зміна ринкової вартості майна банку має важливе значення для його власників. Адже в разі ліквідації банку вони мають право на частину майна відповідно до їх участі у формуванні статутного фонду банку. 3 огляду на це збільшення фонду переоцінки основних засобів показує, наскільки збільшилася частка кожного акціонера банку в його майні. Однак при оцінці цього джерела 
Коиабюк Р. Г.

зростання власного капіталу необхідно враховувати те, що приріст вартості майна за рахунок переоцінки власних будівель i устаткування $є$ істотним джерелом капіталу банків, які мають вкладення в нерухомість, вартість якої підвищується.

Водночас це джерело не є доволі надійним, оскільки вартість матеріальних активів піддається значним коливанням, особливо в умовах нестабільної економіки.

За теперішніх умов банки більшою мірою нарощують власний капітал не за рахунок власних джерел, а шляхом збільшення внесків у статутний капітал. Так, за нашими розрахунками, порівняно з 01.01.2009 р. власний капітал банків України на початок 2010 року зменшився на 4,088 млрд. грн., в той час як статутний капітал зріс на 36,6 млрд. грн. За станом на 01.01.2010 р. розмір власного капіталу банків в Україні був меншим від розміру ïх статутного зареєстрованого капіталу на 4,014 млрд. грн. На кінець першого півріччя 2010 р. розрив між ними дещо скоротився, але залишається значним - 2,556 млрд. грн. [1]. Це дає підстави оцінювати управління власним капіталом як неефективне і свідчить про недостатній рівень наявних резервів (01.07.2010 p. загальні резерви та фонди банків становили лише $11,7 \%$ від їх власного капіталу) та відсутність коштів для розвитку банків i стимулювання їх працівників (на 01.07.2010 р. у власному капіталі банків частка результатів їх діяльності була від'ємною і становила: результати минулих років - мінус 17,8\%, поточного року - мінус 4,6\%, звітного року, що очікують затвердження, мінус 3,5\%) [1].

Як свідчить досвід, нарощування статутного капіталу банків України забезпечувалося за рахунок інвестицій вітчизняних та іноземних інвесторів, а також держави, що, на наш погляд, потребує економічної оцінки з огляду на можливі економічні наслідки для банківської системи і економіки країни в цілому.

На позитивну оцінку заслуговує збільшення статутного капіталу банків за рахунок коштів вітчизняних інвесторів. Адже підвищення рівня капіталізації посилить зацікавленість інвесторів в ефективному використанні ресурсів банківської установи, зміцненні іiі фінансового стану та якості активів, дасть можливість розширити обсяги кредитування національної економіки, що забезпечить умови для економічного зростання країни.

Новим для української практики явищем у сфері вирішення проблеми нарощування власного капіталу банків в умовах фінансової кризи є участь держави у відтворенні й збільшенні капіталу проблемних банків. Держава може брати участь у капіталізації банку за умови, що їй передається одноосібно або разом 3 іншим інвестором не менше $50 \%+1$ акція. Участь держави в капіталізації банків передбачено лише щодо банків:

1) до яких застосовано процедуру запровадження тимчасової адміністрації

2) утворених у формі відкритих акціонерних товариств або перетворених у процесі капіталізації у відкриті акціонерні товариства.

Питання участі держави в капіталізації банку може бути ініційоване НБУ, Мінфіном і власниками банку. В 2009 році за участю держави рекапіталізовано три банки: Укргазбанк, Родовідбанк і банк "Київ". Держава повинна надавати пріоритет участі в ре капіталізації тих банків, які $\epsilon$ системоутворюючими і на обслуговуванні у яких перебувають життєво важливі для економіки країни підприємства й організації. По-друге, повинен бути розроблений механізм повернення до бюджету коштів платників податків, які внаслідок участі держави в ре капіталізації банків були вкладені в статутні капітали банків, що функціонували як приватні комерційні структури.

Нині в Україні як сурогатний інструмент нарощування власного капіталу використовується субординований борг. Субординований борг - це звичайні незабезпечені інструменти, які не можуть бути вилучені в банку раніше п'яти років, а у випадку банкрутства або ліквідації банку повертаються інвесторові після задоволення претензій всіх кредиторів. Залучення коштів на умовах субординованого боргу здійснюється як шляхом укладення прямих договорів між банкомборжником та інвестором, так і шляхом випуску банком-боржником облігацій. Процентна ставка щодо субординованого боргу не може перевищувати протягом усього терміну дії договору максимальну ставку залучення субординованих коштів, що встановлена за рішенням Правління НБУ 3 урахування економічних умов на ринку банківських послуг i приймається банком на відповідну дату, а у випадку емісії облігацій - на дату їх випуску.

У разі зміни максимальної ставки залучення субординованих коштів НБУ повинен офіційно повідомити про це банк не пізніше, ніж за місяць до ії введення в дію. Коли такі кошти залучаються шляхом випуску облігацій, процентна ставка залишається незмінною протягом усього періоду їх обігу, визначеного в рішенні про випуск облігацій. Капіталізація відсотків за субординованим боргом і авансова виплата відсотків не допускаються. Відсотки нараховуються щомісяця. Банк може призупинити виплату відсотків за субординованим боргом за власною ініціативою або за вимогу НБУ лише за умов, визначених Інструкцією 3 регулювання діяльності банків в Україні. При цьому сума субординованного боргу, що 
включається у власний капітал банку, не може перевищувати 50\% від основного капіталу із щорічним зменшенням на 20\% від його первинної вартості.

Якщо на умовах субординованого боргу кошти залучені на строк понад 5 років, банк може здійснювати часткове його погашення, але не раніше, ніж через 5 років від дня його залучення. Кошти субординованого боргу повинні враховуватися в складі власного капіталу банку протягом останніх 5 років дії договору 3 урахуванням розміру амортизації від залишкової суми боргу.

Отже, щодо використання коштів субординованого боргу для нарощування власного капіталу, то вважаємо, що банку доцільно використовувати це джерело підвищення рівня капіталізації з урахуванням того, що за таких умов банк набуває можливості:

1) підвищити капітальну базу без збільшення числа його власників;

2) підвищити прибуток на одну акцію, якщо такі позикові кошити приносять банку дохід за рахунок збільшення активів, що перевищує дохід, який сплачується за такими борговими зобов'язаннями;

3) розв'язати проблему збільшення розмірів власного капіталу при скороченні розмірів оподатковуваного прибутку, тому що витрати 3 виплати купонного доходу за субординованими облігаціями відносяться на витрати банку;

4) обмежити у часі інвестиційні ризики суб'єктів ринку, оскільки кошти субординованого боргу залучаються на терміновій основі.

Одним із можливих зовнішніх джерел зростання обсягу власного капіталу банку $є$ бонусна емісія. Вона доцільна в тому випадку, коли ринкова вартість будь-яких активів банку підвищується порівняно з їх балансовою вартістю. Бонусна емісія припускає, що для створюється резерв для переоцінки власності. Цей резерв капіталізується у вигляді безкоштовного розміщення акцій між акціонерами банку. Завдяки новим акціям збільшується акціонерний капітал, але не роздрібнюється власність і не зменшується вартість випущених до цього акцій.

Як зовнішнє джерело нарощування власного капіталу банк може використовувати емісійний дохід-різницю між емісійною й номінальною вартістю акцій нової емісії.

Його розмір залежить від багатьох факторів, що у сукупності визначають емісійну ціну акцій нового випуску (вартість акцій попереднього випуску, стан ринку цінних паперів, період розміщення тощо). Але за умов фінансової кризи, що охопила не лише банківський сектор, а й фондовий ринок країни, сподіватися на значний вплив цього джерела власного капіталу не варто.
За останні два роки частка емісійного доходу у власному капіталі банківської системи України залишається на рівні 5\%[1].

Отже, за результатами проведеного дослідження можна зазначити, що в умовах кризи:

1) ефективне управління власним капіталом банку $\epsilon$ запорукою активізації його підприємницької діяльності, зміцнення фінансового стану, підвищення довіри економічних агентів до установ банківської системи і розширення кредитної підтримки розвитку реального сектору економіки;

2) нарощування власного капіталу може бути забезпечено за рахунок внутрішніх і зовнішніх джерел, вибір яких треба здійснювати 3 урахуванням усієї сукупності чинників, що визначають можливості та доцільність їх використання певним банком і за певних умов;

3) для більшості банків України таке внутрішнє джерело нарощування власного капіталу, як прибуток, - унеможливлене, оскільки вони мають збиткові результати своєї фінансової діяльності;

4) пріоритетним джерелом нарощування обсягу власного капіталу на сьогодні є збільшення статутного капіталу, що може бути забезпечено за рахунок коштів вітчизняних, іноземних інвесторів та коштів держави;

5) розв'язання проблеми підвищення капіталізації банків за рахунок коштів інвесторів може мати негативні наслідки для національної економіки і національного суверенітету;

6) участь держави у рекапіталізації проблемних банків повинна бути спрямована на підтримку системоутворюючих банків і банків, що обслуговують підприємства базових галузей економіки. На державному рівні необхідно розробити механізм повернення коштів платників податків у бюджет у тій частині, що була спрямована на капіталізацію приватних банків;

7) залучення банками коштів на умовах субординованого боргу доцільно здійснювати 3 урахуванням переваг і недоліків, притаманних цьому джерелу нарощування власного капіталу банку.

\section{Список літератури}

1. Офіційний веб-сайт Національного банку України: // www.bank.gov.ua/

2. Роуз Питер С. Банковский менеджмент - М.: Дело ЛТД. - 1995. - 768c.

3. Основні показники діяльності банків України на 1 лютого 2010 р. // Вісник НБУ. - 2010. - №3. - С.38 


\section{УПРАВЛЕНИЕ СОБСТВЕННЫМ КАПИТАЛОМ БАНКА В УКРАИНЕ}

Разработаны рекомендации по совершенствованию управления источниками наращивания собственного капитала банков и обеспечения его достаточности в условиях финансового кризиса в Украине. Определены методологические подходы к выбору внутренних и внешних источников повышения уровня капитализации банков; дана оченка последствий внесения изменений в условиях финансового кризиса в нормативно-законодательное регулирование достаточностью капитала банков; изложены точку зрения авторов по привлечению средств иностранных инвесторов и государства в уставные капитальг проблемных отечественных банков.

Ключевые слова: нераспределенная прибыль, переоченка основных средств, раскрыты резервы, эмиссионный доход, дополнительная эмиссия акиий, субординированный долг, бонусная эмиссия.

\section{Summary}

Ruslana Kotsabyuk

\section{MANAGEMENT'S CAPITAL BANK IN UKRAINE}

The purpose of this paper is to develop recommendations for improving management capacity sources of equity of banks and ensure its adequacy for the financial crisis in Ukraine. In particular, the methodological approaches to the selection of internal and external sources increase capitalization of banks, the estimation of the consequences of changes in financial crisis to legislative and regulatory capital adequacy of banks, and opinions of the authors set out to attract foreign investments and the state in the authorized capital of domestic banks problem .

Key words: retained earnings, revaluation of fixed assets, disclosed reserves, share premium, the additional issue of shares, subordinated debt, scrip issue. 


\title{
ФІСКАЛЬНА ДЕЦЕНТРАЛІЗАЦІЯ ТА ЇЇ НЕОБХІДНІСТЬ В УКРАЇНІ
}

\begin{abstract}
Розглянені теоретичні та практичні аспекти фіскальної децентралізації. Зроблено порівняний огляд трактувань економічного терміну "фіскальна децентралізація" в науковій вітчизняній та зарубіжній літературі та запропоновано власне визначення. Досліджено систему показників оцінки фіскальної децентралізаиії, розраховано основні показники їі оцінки протягом 1993 - 2010 рр. для України. Запропоновано заходи щчодо поглиблення процесу фіскальної децентралізації в Україні у напрямі збільшення бюджетних прав та зміџнення фінансової основи місиевого самоврядування.

Ключові слова: фіскальна децентралізація, показники оцінки фіскальної децентралізації, доходи місиевих бюджетів, видатки місиевих бюджетів, міжбюджетні трансферти
\end{abstract}

3 розвитком демократичних процесів у світі в останні десятиріччя відбувається і демократизація всіх складових державного життя. Після розпаду Радянського Союзу в країнах Центральної і Східної Європи спостерігається загальна тенденція переходу від централізації до децентралізації як політикоадміністративної, так і економічної складових державної політики. Як складова економічної політики держави реформаційних процесів набуває i бюджетна політика країн. Не залишається осторонь цих процесів ы Україна, яка в 1996 році приєдналася до Європейської хартії про місцеве самоврядування, яка передбачає відокремленість місцевого самоврядування від державної влади і повну незалежність у здійсненні покладених на нього функцій у межах своєї компетенції.

Дослідженням питань фіскальної децентралізації та міжбюджетного регулювання присвячено достатньо праць вітчизняних ы зарубыжних учених. Серед вітчизняних науковців у даному напрямку працюють В.Л. Андрущенко, В.В. Зайчикова, О.П. Кириленко, В.І. Кравченко, І.О. Луніна, К.В. Павлюк, В.М. Федосов, В.Я. Швець, І.Я. Чугунов та деякі інші. Дана проблематика знайшла відображення в наукових працях російських учених О.В. Богачової, Т.В. Грицюк, О.А. Гришанової, В.І. Лексіна, В.Б. Христинко, А.В. Швецова та інших, а також вчених західної школи - Р. Берда, Р. Бала, С. Воліс, Р.Д. Ебел, С. Ілмаз, М. Товінда Рао, В. Оутса, Р. Масгрейва, Ш. Бланкарта, Ч. Тібу та інших науковців. Разом і з значними досягненнями у цій сфері недостатньо досліджені система показників оцінки рівня фіскальної децентралізації, іiі вплив на ефективність міжбюджетного регулювання та розподіл бюджетних повноважень між різними рівнями влади.

Метою статті є дослідження фіскальної децентралізації як комплексного процесу, який має позитивні і негативні сторони, визначення системи показників ії оцінки, а також розрахунок основних показників в Україні.

На користь децентралізації державних функцій існують 2 основні аргументи:

1) децентралізація повноважень із надання бюджетних послуг підвищує ефективність бюджетних видатків, оскільки дозволяє більш повно врахувати потреби мешканців, наближує органи влади до населення, підвищує оперативність рішень;

2) децентралізація повноважень із формування доходів бюджету дозволяє більш повно врахувати специфіку і склад податкової бази, чим забезпечується більша наповнюваність місцевого бюджету.

Основою для теорії децентралізації $\epsilon$ однойменна теорема В. Оутса, сформульована ним у 1972 р. Згідно неї, якщо в ізольованих територіальних утвореннях існує можливість для надання суспільного блага і його граничні витрати дорівнюють середнім витратам на його виробництво в кожному з утворень, незалежно від того, чи надається воно централізованим чи децентралізованим шляхом, то надання цього блага місцевими органами самоврядування в кількості, яка відповідає реальному попиту, завжди буде більш ефективним, ніж його надання урядом у фіксованому обсязі (на постійному рівні) [1].

Ш. Бланкарт на основі цієї теореми сформулював наступний висновок щодо бюджетного устрою країни: фінансово - політична відповідальність за формування дохідної та планування видаткової частини бюджету має покладатися, насамперед, на місцеві органи влади, а не на регіональний чи центральний уряд, оскільки саме таким чином відбувається більш повне врахування потреб громадян, які проживають в окремих територіальних одиницях [2, c. 597]. 
Легкостуи I. I.

Поняття децентралізації може бути представлено 3 двох позицій. По-перше, це передача функцій управління від центральних органів влади місцевим, розширення кола повноважень нижчестоящих органів управління шляхом скорочення повноважень вищестоящих. Децентралізація дозволяє підвищити ефективність управління за рахунок наближення влади до виборців, більш повного врахування місцевої специфіки та уподобань населення. По-друге, це політика фірм 3 децентралізації управління, яка спрямована на те, щоб керівники структурних підрозділів діяли так, ніби вони очолюють незалежні компанії [3].

Із вищезазначеного випливає, що процеси децентралізації можуть відбуватись як на макрорівні - коли функції центральної влади частково передаються на місця, так і на мікрорівні
- коли підрозділи підприємств та організацій отримують ширші повноваження.

Автори монографії "Фінанси України: інституційні перетворення та напрями розвитку" вважають, що децентралізація являє собою передавання владних повноважень від органів центральної влади до органів регіонального рівня та органів самоврядування [4, с. 723].

Американський учений М. Белл пропонує наступне узагальнене визначення децентралізації - це спосіб виміру величини переходу національної економіки від адміністративно-командної до ринкової.

Існують різні види децентралізації, основними 3 яких є економічна, адміністративна та політична. Види та форми децентралізації відображені в табл. 1.

Таблиия 1

Види та форми дентралізації

\begin{tabular}{|c|c|c|}
\hline Вид децентралізації & \multicolumn{2}{|c|}{ Форми децентралізації } \\
\hline Політична & $\begin{array}{l}\text { ДЕМОКРАТИЗАЦІЯ } \\
\text { Шляхом обрання представницьких } \\
\text { органів місцевого самоврядування, } \\
\text { залучення ге громадян } \\
\text { безпосередньо, так і опосередковано } \\
\text { до процесу прийняття рішень } \\
\text { місцевими урядами }\end{array}$ & $\begin{array}{l}\text { ДЕВОЛЮЦІЯ } \\
\text { перерозподіл сфер відповідальності } \\
\text { щодо надання суспільних благ } \\
\text { шляхом виокремлення благ які } \\
\text { надаються } \\
\text { самоврядуванням безпосередньо }\end{array}$ \\
\hline Адміністративна & $\begin{array}{l}\text { ДЕКОНЦЕНТРАЦІ } \\
\text { передання повноважень органами } \\
\text { виконавчої влади центрального уряду } \\
\text { децентралізованим відомствам } \\
\text { (представникам центрального уряду) } \\
\text { на місцевому рівні }\end{array}$ & $\begin{array}{l}\text { ДЕЛЕГУВАННЯ } \\
\text { передання повноважень щодо } \\
\text { надання державних послуг органам } \\
\begin{array}{l}\text { місцевого } \\
\text { (здійснення агентських послуг) }\end{array}\end{array}$ \\
\hline Економічна & $\begin{array}{l}\text { ЛІБЕРАЛІЗАЦІЯ } \\
\text { діяльності, РОЗДЕРЖАВЛЕННЯ } \\
\text { діної } \\
\text { шляхом приватизації та передання } \\
\text { державного майна у комунальну } \\
\text { власність }\end{array}$ & $\begin{array}{l}\text { ФІСКАЛЬНА ДЕЦЕНТРАЛ ІЗАЦІЯ } \\
\text { збільшення фінансової автономї } \\
\text { органів місцевого самоврядування }\end{array}$ \\
\hline
\end{tabular}

Джерело: [5, с. 60].

Економічна децентралізація у сфері міжбюджетних відносин отримала назву фіскальної або бюджетної децентралізації. Єдиного визначення цього поняття в фінансовій науці немає, а терміни "фінансова децентралізація", "фіскальна децентралізація", "бюджетна децентралізація", "бюджетно-податкова децентралізація" ототожнюються.

У західній науці частіше вживається термін фіскальна децентралізація. У зарубіжних країнах вона реалізовується шляхом: самофінансування за рахунок збирання плати за надані послуги зі споживачів, застосовування схеми спільного фінансування послуг через грошові та трудові внески споживачів, збільшення місцевих надходжень через запровадження майнового податку або податку на продаж, використання міжбюджетних трансфертів, санкціонування муніципальних запозичень і мобілізації ресурсів центральних або місцевих органів влади за допомогою гарантії позик.

"Головною метою фіскальної децентралізації $€$ наближення управління до людей, а це вимагає зміцнення фінансів місцевих урядів" [6, с. 22]. Фіскальна децентралізація вимагає більшої автономії місцевої влади в ухваленні незалежних фіскальних рішень. Для проведення політики фіскальної децентралізації потрібно виконати 
необхідні та бажані умови.

До необхідних умов належать: політична автономія, яка забезпечується шляхом обрання рад на місцевих виборах, призначення за погодженням 3 радою на ключові посади керівників виконавчих органів місцевого самоврядування, що забезпечує ї відповідальність перед населенням. Іншими необхідними умовами фіскальної децентралізації $\epsilon$ відповідальність у видатковій сфері, значний обсяг податкових повноважень, бюджетна автономія, прозорість.

До бажаних умов відноситься: свобода від надмірного контролю над видатками 3 боку центрального уряду; безумовні трансферти від центрального уряду; повноваження у сфері здійснення запозичень.

Поняття "фіскальна децентралізація" або "бюджетно-податкова децентралізація" трактується різними вченими неоднаково. Так, автори Зеленої книги "Бюджетна децентралізація в Україні в контексті реформи місцевого самоврядування" пропонують визначення: "Бюджетна децентралізація -- це процес передання повноважень (функцій, компетенцій і відповідальностей) від центрального уряду до місцевих урядів (органів місцевого самоврядування). Така передача повноважень має супроводжуватися передачею відповідних фінансових ресурсів на виконання цих повноважень через запровадження місцевих податків або трансформації чи закріплення частини загальнодержавних податків за місцевими бюджетами, що отримали нові повноваження. Бюджетна децентралізація також $\epsilon$ передачею повноважень від вищих органів управління до нижчих, наприклад, від регіональних до муніципальних або місцевих." [7].

Російські науковці В. Лексін та А. Швецов під бюджетно-податковою децентралізацією розуміють регламентовану форму паралельної реалізації єдиних правил побудови внутрішньодержавних бюджетних і податкових підсистем (в першу чергу - регіональних i муніципальних) i організоване розосередження окремих технологічних стадій бюджетного процесу (наприклад, відокремлення казначейського виконання бюджету) та податкового процесу (наприклад, розділення податкової служби та податкової поліції) за різними рівнями державно-територіального устрою [8, с. 54].

Вважаємо, що, враховуючи всі позитивні сторони даних розгорнутих визначень, їх доцільно було б доповнити метою процесу фіскальної децентралізації та іï принципами. Отже, не претендуючи на довершеність, пропонуємо власне визначення фіскальної децентралізації. Це - побудований на принципі субсидіарності процес розширення видаткових та доходних повноважень, збільшення фінансової незалежності регіональних та місцевих органів влади 3 метою підвищення їх фінансової ініціативи та відповідальності, ефективності міжбюджетних відносин.

Аргументами на користь фіскальної децентралізації є те, що: фіскальна децентралізація підвищує конкуренцію серед місцевих урядів, що, у кінцевому підсумку, обмежує обсяги суспільного сектору; децентралізація підвищує ефективність, оскільки місцеві уряди мають кращу інформацію про потреби своїх резидентів, ніж центральний уряд; фіскальна децентралізація сприяє ефективнішому розміщенню ресурсів.

Більша децентралізація підвищує кількість альтернативних фіскальних юрисдикцій, тому, відповідно до аналізу Тьєбу, будь-яке намагання підвищити ставки податків у одній юрисдикції призведуть до міграції резидентів до іншої юрисдикції з метою уникнення високих податків. Платники податків мігрують до альтернативних юрисдикцій і міжюрисдикційна конкуренція обмежує надмірний податковий вплив урядів. Відповідно до позиції Тьєбу, у 1980 р. Бренан і Б'юкенен розробили гіпотезу "Левіафана", в якій довели, що фіскальна децентралізація $\epsilon$ стримуючим фактором у максимізації доходів урядом. Модель "Левіафана" передбачає, що загальний обсяг суспільного сектора повинен інверсійно варіювати з децентралізацією [6, с. 10]. Тобто "наскільки уряд діє в інтересах максимізації власних доходів, настільки горизонтальна i вертикальна конкуренція між різними рівнями врядування може зумовити розмір їх бюджету i так обмежити загальний розмір бюджету державного сектора ... фіскальна децентралізація може допомогти запобігти надмірній пропозиції суспільних товарів" [9, с. 289].

Класична теорія фіскальної децентралізації передбачає, що видаткові повноваження та фінансові джерела будуть розмежовані між рівнями державного управління одночасно і кожен владний рівень фінансуватиме визначений обсяг видатків відповідно до своїх повноважень. Але в багатьох країнах повноваження більш децентралізовані, ніж фіскальні джерела, тому постає необхідність передачі фінансових ресурсів від центральних до регіональних органів влади та органів місцевого самоврядування. Існує багато шляхів вирішення цього питання, зокрема побудова системи трансфертів.

Принципами фіскальної децентралізації розвинених ринкових країн $\epsilon$ ефективність, відкритість та відповідальність. На цих принципах базується розподіл повноважень для виконання визначених функцій органів державної влади та надання бюджетних послуг, повноважень 
Легкоступ I. I.

мобілізації доходів та здатність місцевих урядів брати позики. Органи місцевої влади забезпечують реалізацію місцевих інтересів, надають громадські послуги, виконують делеговані повноваження органів виконавчої влади. Крім того, важлива роль місцевих бюджетів у соціально-економічному розвитку території.

У кожній країні процес децентралізації проходитиме по-різному, враховуючи, принаймні, особливості політичної системи. Зокрема, детальному аналізу підлягають адміністративні важелі впливу центральної влади. Особливо це стосується бюджетного законодавства в частині норм складання та виконання місцевих бюджетів, оскільки фінансування делегованих повноважень здійснюватиметься за рахунок трансфертів 3 центрального бюджету. Крім цього, варто зважати на кількість рівнів органів влади, площу та населення адміністративно-територіальних утворень, а також систему виборів до місцевих рад.

Ефективне застосування інструментів децентралізації можливе лише за умови врахування двох критеріїв:

1) економічної ефективності, макроекономічної стабільності й ефективного перерозподілу;

2) політичної ефективності.

Економічну ефективність належить розглядати в двох аспектах: ефективності розподілу ресурсів та ефективності виробництва суспільних благ. Щодо першого аспекту, то розглядається відповідність створеного (виробленого) та очікуваного споживачами набору суспільних товарів та послуг, і як результат - рівень задоволення споживачів. Висока ефективність розподілу ресурсів $є$ безпосереднім результатом децентралізації. Другий аспект грунтується на собівартості виробництва суспільних благ, зниження або підвищення якої є підставою до перегляду інструментарію децентралізації. Макроекономічна ситуація у державі свідчить про загальні результати політики децентралізації. I навпаки, застосовуючи макроекономічний інструментарій, держава може не тільки узгоджувати, але й покращувати результативність цієї політики. Основним критерієм є результати перерозподілу ресурсів, товарів та послуг між членами суспільства, а також між адміністративно-територіальними одиницями.

Децентралізація також впливає на основні елементи політичної системи держави. Це проявляється насамперед у наданні органам місцевого самоврядування повноважень щодо участі у прийнятті політичних рішень. Навіть за умови відсутності позитивного економічного ефекту від децентралізації обов'язково наявні якісні соціальні зрушення. Жителі громади (базового рівня врядування у державі) позиціонують себе як активних учасників усіх суспільних процесів адміністративнотериторіального утворення, де вони проживають. Оптимальний розподіл повноважень між центром та регіонами, 3 одного боку, повинен обмежити авторитаризм центральних органів влади, а 3 другого - запобігти регіоналізації країни, що особливо актуально для країн, які розвиваються.

Кожна держава повинна віднайти індивідуальний підхід до застосування інструментарію децентралізації, враховуючи специфіку географічного розташування, забезпечення природними ресурсами, економіки та політичної системи.

Фіскальна децентралізація має свої як позитивні, так і негативні сторони.

До переваг можна віднести наступні. Децентралізація повноважень із надання бюджетних послуг підвищує ефективність бюджетних видатків, оскільки наближує органи місцевої влади до потреб територіальних громад, робить їх підзвітними виборцям, дозволяє більш повно враховувати їх переваги, вчасно реагувати на зміни, що відбуваються. Територіальна ж громада, будучи активним суб'єктом впливу на процеси соціально-економічного розвитку, може впливати на черговість виконання та фінансування тих чи інших місцевих програм.

Децентралізація доходних повноважень дозволяє більш точно врахувати специфіку та склад податкової бази, і тим забезпечити високий рівень надходжень до бюджету.

Децентралізація бюджетних коштів посилює стимули до ліквідації тіньового бізнесу на теренах окремої території, оскільки більш чітко видимий розподіл коштів і відкритість політичних рішень в інтересах територіальної громади. Також у випадку бюджетної децентралізації підвищується відповідальність місцевої влади перед громадою за повноту виконання покладених на неї функцій, а в умовах сучасної пропорційної виборчої системи - i перед політичними партіями, які вона представляє.

Характеризуючи бюджетну децентралізацію в цілому як позитивний прогресивний процес, треба враховувати і проблеми, які вона може створити.

Фіскальна децентралізація ускладнює процес перерозподілу коштів через бюджет та управління бюджетним процесом узагалі, оскільки центральному уряду важче децентралізувати відповідальність за джерела оподаткування, ніж за видатки місцевих бюджетів. Також, в умовах децентралізації важче узгоджувати локальні потреби окремих територіальних громад 3 
макроекономічними цілями всієї держави.

Недоліком надмірної фіскальної децентралізації можна вважати можливість зростання диференціації між "багатими" та "бідними" регіонами. Наділення органів місцевого самоврядування додатковими повноваженнями 3 оподаткування або самостійного визначення структури витрат, місцевих запозичень призведе до ситуації, коли економічно більш розвинені регіони опиняться у вигідніших умовах, ніж економічно слабкі регіони. Краща податкова база одних регіонів забезпечить більш високий рівень забезпечення одного мешканця, ніж в тих регіонах, де податкова база слабкіша. Тобто, необхідне буде втручання держави 3 механізмом фінансового вирівнювання.

Запроваджуючи децентралізацію управління, уряди окремих країн розраховують на прискорення темпів економічного зростання, підвищення ефективності та результативності надання державних послуг. 3 іншого боку, ряд зарубіжних учених вважають, що власне досягнення країною високого ступеня економічного розвитку $є$ підставою для децентралізації управління, в тому числі у бюджетній сфері. Виходячи з цього, можна стверджувати, що існує певний ступінь децентралізації управління, який залежить від низки показників: загального стану економіки країни, рівня диспропорцій у розвитку регіонів, унітарного чи федеративного устрою країни, стану державного управління, політичних інституцій, сформованості законодавчої бази тощо. Для кожної країни ця величина оптимуму буде різною, тому кожний уряд вибирає свій ступінь децентралізації залежно від перерахованих факторів.

Отже, необхідно знайти оптимальні межі фінансової незалежності або фіскальної автономії місцевих бюджетів, які б забезпечили ефективний розвиток як центрального бюджету, так і місцевих бюджетів, усунення фінансових дисбалансів як по вертикалі, так і по горизонталі. Для оцінки рівня фіскальної автономії регіонів держави застосовується коефіцієнт фіскальної автономії, який розраховується як частка доходів місцевих бюджетів у загальному обсягу державних доходів [10, с. 324]. Показник фіскальної автономії напряму пов'язаний із рівнем фіскальної децентралізації.

Щоб знайти оптимальні межі фінансової незалежності, необхідно спочатку визначити систему показників, за допомогою яких можна виміряти фіскальну децентралізацію.

Основні показники рівня фіскальної децентралізації вимірюють співвідношення фінансів центрального уряду та місцевих урядів за такими позиціями:
- частка центрального та місцевого урядів у консолідованому бюджеті країни;

- частка доходів і видатків бюджетів місцевого самоврядування у консолідованому бюджеті країни.

Показники частки загальних урядових видатків, видатків центрального уряду, видатків місцевих урядів у ВВП входять до групи показників, що враховуються у моделях, які характеризують вплив децентралізації на розмір публічного сектору та економічне зростання.

В економетричних моделях, розроблених фахівцями Світового банку, аналізується вплив фіскальної децентралізації на ефективність розміщення ресурсів 3 двох сторін, по-перше, щодо впливу фіскальної децентралізації на частку уряду у ВВП, по-друге, щодо впливу фіскальної децентралізації на економічне зростання 3 використанням інтенсивної форми продуктивної функції. У першій моделі залежною змінною $є$ загальна частка уряду у ВВП, а незалежними змінними виступають: показник децентралізаціїчастка видатків місцевих урядів у загальних урядових видатках, яка визначається як відношення видатків місцевого уряду до загальних урядових видатків; чисельність населення та ВВП на душу населення. У другій моделі залежною змінною є реальний валовий внутрішній продукт на душу населення, незалежними змінними $€$ капітальні вкладення на одного працівника та частка видатків місцевих урядів у загальних урядових видатках.

Серед інших показників фіскальної децентралізації розраховують наступні:

- співвідношення між податками, які встановлюються центральним урядом, та податками, що визначаються місцевими урядами - індикатор законодавчо встановленої фіскальної децентралізації;

- частка місцевих урядів у загальних доходах, які збираються від імені центрального уряду індикатор дійсної децентралізації фіскальної (податкової) ресурсної бази;

- частка у загальних доходах, зібраних у внутрішніх межах, або утриманих місцевими урядами доходів - індикатор дохідної автономії місцевих урядів;

- частка доходів центрального уряду, переданих субнаціональним урядам - індикатор децентралізації централізованих доходів (фінансових ресурсів);

- частка загальних фіскальних видатків, що ефективно контролюється центральним урядом індикатор контролю над видатками центральним урядом;

- частка загальнонаціональних фіскальних видатків, які ефективно контролюються 
Легкоступ I. I.

місцевими урядами - видаткова автономія місцевих урядів;

- запозичення місцевих урядів на фінансових ринках - індикатор децентралізації бази фіскальних ресурсів [9, с. 101 - 102].

У випадках, коли на основі вищезазначених параметрів робиться висновок про те, що рівень фіскальної децентралізації низький, державним органам треба спільно 3 органами місцевого самоврядування розробити заходи, які надають змогу збільшити частку місцевих доходів, що повністю i/aбо частково залишаються у розпорядженні цих органів, не посилюючи загальний податковий тягар.

Для характеристики загального рівня децентралізації бюджетної системи України застосуємо ряд основних показників оцінки. Це такі показники як:

- частка доходів місцевих бюджетів у ВВП;

- частка доходів місцевих бюджетів у доходах зведеного бюджету;

- частка видатків місцевих бюджетів у ВВП;

- частка видатків місцевих бюджетів у видатках зведеного бюджету;

- частка трансфертів, що надаються 3 вищестоячих бюджетів місцевим бюджетам;

- частка місцевих податків і зборів у загальних доходах місцевих бюджетів.

Розраховані числові значення цих показників наведені в таблиці 2.

\section{Основні показники оцінки рівня фіскальної децентралізації в Україні}

Таблиия 2

\begin{tabular}{|l|c|c|c|c|c|c|}
\hline \multicolumn{1}{|c|}{ Показник } & 1993 рік & 1998 рік & 2001 рік & 2004 рік & 2007 рік & 2010 рік \\
\hline $\begin{array}{l}\text { Доходи місцевих бюджетів (без } \\
\text { МБТ)у \% до ВВП }\end{array}$ & 16,0 & 12,7 & 8,7 & 6,6 & 8,1 & 7,4 \\
\hline $\begin{array}{l}\text { Частка доходів місцевих } \\
\text { бюджетів (без МБТ) у доходах } \\
\text { зведеного бюджету, \% }\end{array}$ & 47,8 & 45,7 & 32,3 & 24,9 & 26,5 & 25,6 \\
\hline $\begin{array}{l}\text { Видатки місцевих бюджетів (без } \\
\text { МБТ)у \% до ВВП }\end{array}$ & 15,2 & 14,7 & 11,0 & 11,2 & 13,4 & 13,9 \\
\hline $\begin{array}{l}\text { Частка видатків місцевих } \\
\text { бюджетів (без МБТ) у видатках } \\
\text { зведеного бюджету, }\end{array}$ & 39,4 & 48,1 & 40,7 & 37,8 & 42,4 & 40,2 \\
\hline $\begin{array}{l}\text { Частка трансфертів у доходах } \\
\text { місцевих бюджетів, \% }\end{array}$ & 10,0 & 14,3 & 29,0 & 42,5 & 45,5 & 49,5 \\
\hline $\begin{array}{l}\text { Частка місцевих податків і } \\
\text { зборів у загальних доходах } \\
\text { місцевих бюджетів, \% }\end{array}$ & 1,0 & 2,6 & 2,1 & 1,4 & 0,7 & 0,5 \\
\hline
\end{tabular}

Джерело: розраховано автором за даними статистичних збірників Міністерства фінансів України

Як видно з таблиці 2, протягом 1993 - 2010 рр. частки доходів місцевих бюджетів (без міжбюджетних трансфертів) у ВВП та доходах зведеного бюджету зменшились 3 16,0 \% до 7,4 $\%$, та 3 47,8 \% до 25,6 \%, відповідно. Частка видатків місцевих бюджетів (без міжбюджетних трансфертів) у ВВП протягом цього періоду зменшилась 3 15,2 \% до 13,9\%. Частка видатків місцевих бюджетів (без міжбюджетних трансфертів) у видатках зведеного бюджету зменшилась 3 48,1 \% у 1998 р. до 40,2 \% у 2010 р. Показник частки трансфертів у доходах місцевих бюджетів зріс з 10,0 \% у 1993 р. до 49,5 \% у 2010 p.

Частка місцевих податків у бюджетних та макроекономічних показниках свідчить про рівень самостійності у прийнятті фінансових рішень місцевою владою, адже в іiі компетенції встановлювати та скасовувати види місцевих податків, змінювати ставки по них, надавати пільги. Частка місцевих податків у загальних доходах місцевих бюджетів зменшилася з 2,6 \% у 1998 р. до $0,5 \%$ у 2010 p.

Отже, зроблений аналіз зміни показників оцінки рівня фіскальної децентралізації в Україні свідчить, що протягом 1993 - 2010 років посилювались тенденції державного регулювання в розподілі бюджетних коштів, знижувався рівень фіскальної децентралізації та фіскальної автономії місцевих бюджетів. Одночасно зменшувався вплив місцевих органів влади на соціальноекономічні процеси в регіонах, спадала їх фінансова 
ініціатива, посилювались споживацькі тенденції. В 2010 році майже половина всіх доходів місцевих бюджетів формувалась за рахунок трансфертів $(49,5$ \%), що було найвищим показником за роки незалежності держави.

Єдиних теоретично обгрунтованих положень, придатних для будь-якої країни, які б дозволяли кількісно визначити оптимальне співвідношення між фіскальною децентралізацією та централізованим перерозподілом бюджетних доходів не існує. Залежно від історичних традицій у відносинах центру і регіонів, їх політичної автономії, адміністративного устрою таке співвідношення може суттєво відрізнятись в різних країнах. Більш повно характеризувати рівень фіскальної децентралізації в Україні можна лише порівнявши внутрішні показники 3 аналогічними показниками в інших державах.

Отже, доходи місцевих бюджетів в Україні формуються переважно або за рахунок закріплених загальнодержавних податків, на які місцева влада не впливає, або за рахунок трансфертів 3 державного бюджету. Це свідчить про дуже низьке як фіскальне значення, так i низький рівень фіскальної автономії та децентралізації місцевих бюджетів в Україні.

Першим кроком у здійсненні політики фіскальної децентралізації в Україні стала ратифікація Верховною Радою України Свропейської хартії місцевого самоврядування [11]. Хартія зобов'язує держави закріпити у внутрішньому законодавстві і застосовувати на практиці сукупність юридичних норм, що гарантують політичну, адміністративну та фінансову незалежність муніципальних утворень. Вона також установлюе необхідність конституційного регулювання автономії місцевого самоврядування. Наступним позитивним кроком у цьому напрямі стало прийняття Кабінетом Міністрів України 23 травня 2007 року "Концепції реформування місцевих бюджетів" [12]. Її метою оголошено зміцнення фінансової основи місцевого самоврядування, посилення впливу системи формування місцевих бюджетів на соціальноекономічний розвиток і поліпшення добробуту громадян.

Дані кроки мали здебільшого декларативний, a не практичний характер. Прийняття Бюджетного кодексу у новій редакції 2010 року стало важливою віхою у політиці фіскальної децентралізації в Україні. Даним документом було віднесено деякі доходи державного бюджету до місцевих бюджетів (ст. 64), розширено джерела формування доходів, що не враховуються при визначенні обсягу міжбюджетних трансфертів (ст. 69), бюджету розвитку місцевих бюджетів (ст. 71). Водночас політика фіскальної децентралізації потребує подальших реальних кроків щодо збільшення бюджетних прав та зміцнення фінансової основи місцевого самоврядування. Таким кроками, на наш погляд, можуть стати передання місцевим бюджетам часток загальнодержавних податків - на прибуток та додану вартість. До місцевих податків, вважаємо, доцільно віднести податок з доходів фізичних осіб і плату за землю, які суттєво збільшать їх питому вагу.

Запровадження політики фіскальної децентралізації в Україні має стати дієвим чинником стабілізації соціально-економічної ситуації, виходу із фінансової кризи, подолання суперечностей між різними рівнями влади по вертикалі, організації взаємовідносин між центром, регіонами та територіальними громадами на принципах розподілу сфер відповідальності та компетенції, а також партнерства у сфері забезпечення громадян України державними та місцевими благами. Це передбачає здійснення комплексу заходів політичного, правового, економічного та організаційного характеру.

Перспективи подальших досліджень необхідно зосередити у напрямі пошуку оптимальних кількісних параметрів і визначення конкретних заходів у здійсненні політики фіскальної децентралізації в Україні.

\section{Список літератури}

1. Oates W. Fiscal Federalism [текст] / W. Oates. - New York: Harcourt Brace Jovanovich, 1979.

2. Бланкарт Ш. Державні фінанси в умовах демократії: Вступ до фінансової науки [текст] / Ш. Бланкарт. Пер. 3 нім., ред. В.М. Федосова. - К.: Либідь. 2000. - 654 с.

3. Николаенко Е.И. Изменение степени децентрализации [текст] / Е.И. Николаенко, Н.В. Голованова. Материалы конференции "Бюджетный федерализм и финансовое управление на местном уровне". - М.: РАКС, 2002. - Модуль 14.

4. Фінанси України: інституційні перетворення та напрями розвитку [текст] / [Чугунов І.Я., Дьяченко Я.Я., Міщенко В.І. та ін.]; за ред. І.Я. Чугунова. - К.: ДННУ АФУ, 2009. - 848 с.

5. Зайчикова В.В. Місцеві фінанси України та європейських країн [текст] / В.В. Зайчикова. - К.: НДФІ, 2007. - 299 c.

6. Ebel R.D. Intergovornmental Relations: Issues in Public Policy [текст] / R.D. Ebel, S. Yilmas. Course "Intergovernmental Fiscal Relation". - Budapest: CEU, 1999.

7. Зелена книга. Бюджетна децентралізація в Україні в контексті реформи місцевого самоврядування [Електорнний ресурс]. - Режим доступу: http// www.icps.kiev.ua/project.htm/?pid=97.

8. Лексин В. Бюджетный федерализм: диалектика централизации и децентрализации [текст] / В. Лексин, А. Швецов // Рос. экон. журнал. - 2002. - № 7. - С. 5377. 
Легкоступ I. I.

9. Хоффманн Л. Україна на шляху до Свропи [текст] / Л. Хоффманн, Ф. Мьоллерс. - К., Фенікс, 2001.

10. Фінансово-монетарні важелі економічного розвитку: В 3 т. / За ред. чл. - кор. НАН України А.І. Даниленка. Т. 1: Фінансова політика та податковобюджетні важелі її реалізації [текст]. - К.: Фенікс, 2008. $-468 \mathrm{c}$.

11. Про ратифікацію Європейської хартії місцевого самоврядування: закон України від 15 липня 1997 року № 452/97-ВР [текст] / Верховна Рада України. Відомості Верховної Ради України (ВВР), 1997. - № 38. - Ст. 249

12. Концепція реформування місцевих бюджетів: схвалена розпорядженням Кабінету Міністрів України від 23 травня 2007 р. № 308-р. [Електронний pecypc]. - Режим доступу: http://www.minfin.gov.ua/ control/uk/publish/article?art_id=73747\&cat_id=53608.

\section{Аннотация}

Игор Легкоступ

\section{ФИСКАЛЬНАЯ ДЕЦЕНТРАЛИЗАЦИЯ И ЕЕ НЕОБХОДИМОСТЬ В УКРАИНЕ}

Рассмотрены теоретические и практические аспекты фискальной децентрализации. Сделан сравнительный обзор определений экономического термина "фискальная децентрализация" в научной отечественной и зарубежной литературе, предложено собственное определение. Исследовано систему поакзателей оценки фискальной децентрализачии, рассчитано основные ее показатели 1993-2010 г2. для Украины. Предложено пути углубления процесса фискальной децентрализации в Украине в направлении увеличения бюджетных прав и укрепления финансовой основы местного самоуправления.

Ключевые слова: фискальная децентрализация, показатели оценки фискальной децентрализации, доходы местных бюджетов, расходы местных бюджетов, межбюджетные трансфертьл

\section{Summary}

Igor Legkospup

\section{FISCAL DECENTRALIZATION AND ITS NECESSITY IN UKRAINE}

In this article theoretical and practical aspects of fiscal decentralization have been examined. Comparative survey, of interpretation of economic term "fiscal decentralization" in scentific home and foreign literature has been made and own definition has been proposed. The system of indices of estimation of fiscal decentralization has been investigated, main indices of its estimation during 1993 - 2010 years for Ukraine have been calculated. Measures as to deepening of the process of fiscal decentralization in Ukraine in the direction of increase in budget rights and strengthening of financial basis of local government have been suggested.

Key words: fiscal decentralization, parameters of fiscal decentralization estimation, local budgets income, local budgets costs, interbudgetary transferts 


\title{
РЕЗУЛЬТАТИВНІСТЬ ПЛАНУВАННЯ ВИДАТКОВОЇ ЧАСТИНИ БЮДЖЕТУ ЯК ОСНОВА ЕФЕКТИВНОГО БЮДЖЕТНОГО МЕНЕДЖМЕНТУ
}

\begin{abstract}
Проаналізовано ефективність планування показників Державного та зведеного бюджету України. Показано необхідність використання якісного методу оиінки ефективності планування бюджету. Визначено головні перешкоди на шляху повноцінного запровадження технологій бюджетування в країні. Запропоновано заходи для організаџії високоефективної системи державного бюджетного планування.

Ключові слова: бюджет, ефективність планування, Державний бюджет Украйни, зведений бюджет, державні видатки.
\end{abstract}

Одним із важливих моментів відповідальності державної влади перед суспільством, виконавчої влади перед законодавчою $є$ докази того, що зібрані у вигляді податків та витрачені на різні цілі суспільні кошти дали необхідний результат, що кошти не просто витратили, а використали раціонально задля реалізації певних конкретних заходів. Оскільки державні фінанси втілюються у державному бюджеті, внутрішньо наповнюючи його зміст та виступаючи одночасно і зовнішнім виявом його існування, то йдеться про таку побудову (у плануванні та реалізації) бюджету, яка дала б змогу упевнитися 3 достатньою достовірністю, що суспільні кошти витрачені недарма, а з відповідною ефективністю. Такі вимоги до бюджету постають лише у ринковій економіці.

Зростання державних видатків є проблемою, яка тісно пов'язана із проблемами бюджетної політики, безпосередньо впливає на ії інститути й міру втручання держави в соціально-економічні процеси, що зумовлює актуальність досліджень в цьому напрямку та приверстає особливу увагу вчених-економістів. Зокрема, проблематиці державних видатків присвячені праці В. Андрущенка, В.Дем'янишина, Я. Дяченко, I. Запатріної, Л. Клеця, Л.Лисяк, І.Луніної , Л. Панкевича, В. Опаріна, О. Романенко, Л Сафонової, А. Скрипника, В. Федосова, С Юрія та інших.

У країнах з розвиненою економікою нині сформувалася досить потужна модель функціонування державних фінансів, в основу якої покладено принцип оптимальності побудови й використання державних фінансів в інтересах суспільства в цілому. Оптимальність означає, що рівень централізації бюджетних повноважень і бюджетних ресурсів має як забезпечувати державу достатніми коштами, так і не підривати фінансової бази суб'єктів господарювання, а ступінь перерозподілу - як достатньо впливати на пропорції соціально-економічного розвитку, так і не створювати "утриманської" психології у громадян. Тобто західна модель оцінки ефективності бюджету вимагає встановлення збалансованості інтересів усіх субмєктів фінансових відносин [14, с.66]. Західні вчені, зокрема автор відомого підручника "Державні фінанси в умовах демократії" Ш. Бланкарт, розглядає використання методів оцінки ефективності бюджету як вплив ринкових підходів на стан державних фінансів [10, с.120]. Адже в умовах ринку результативність будь-яких грошових витрат - обов'язкова умова успішної діяльності ринкового індивіда. 3 таким трактуванням, очевидно, варто погодитися, зважаючи, однак, на те, що йдеться тільки про вплив ринкових відносин, але не про перехід на ринкові відносини між державою і членами суспільства. Держава виробляє суспільні блага i надає їх членам суспільства здебільшого безоплатно. Але це не означає, що держава не повинна цікавитися затратами на виробництво таких благ і конкретними результатами їх використання. 3 точки зору економічної ефективності зрозуміло, що краще, коли виробляється більший обсяг безоплатних благ 3 меншими витратами. Тоді можна говорити про підвищення суспільної продуктивності і зниження трудомісткості та інтенсивності суспільного часу й праці, що необхідні для їх виробництва.

Проте, на нашу думку, на сьогодні в Україні відсутній механізм оцінки ефективності планування бюджету відповідно до принципів функціонування ринкової економіки.

Саме тому для оцінки ефективності планування 
ЖебчукР. Л.

бюджету як основний ми використаємо метод, який базується на порівнянні фактичних і планових показників бюджетного фінансування за конкретними статтями. Цей метод за інерцією лишився головним під час проведення реформ у перехідний період і фактично таким виступає й дотепер, оскільки традиції його використання у країнах постсоціалістичного простору доволі стійкі.

Для проведення аналізу ефективності планування Державного бюджету України за видатками використаємо прогнозні, планові та фактичні показники за окремими статтями видатків за 2002-2008 роки (Таблиця 1).

Як бачимо 3 таблиці 1 , видатки бюджету мають досить значну відносну похибку планування. Зокрема, дані таблиці свідчать, що похибка планування знаходиться в межах від $+48,0 \%$ (капітальні видатки у 2004 році) до -79,2\% (спостерігалась 3 капітальних видатків у 2005 році).

Такий результат, на нашу думку, є емпіричним підтвердженням низького рівня ефективності бюджетного планування в Україні. Як бачимо, похибка планування по видатках бюджету в цілому має трохи менший інтервал коливання, однак він $є$ також досить значним. Розглядаючи стан планування видатків бюджету за окремими статтями економічної класифікації, стає зрозумілим той факт, що найгірша ситуація 3 плануванням показників капітальних видатків.
Так, за період 32006 по 2008 рік недофінансованими за даною статтею залишили близько 50\% видатків, а в 2005 році це відсоток, взагалі, склав 79,2 пункти. Водночас, бачимо, значне перевитрачання коштів бюджету на поточні видатки (максимум у 2005 році $+20,8 \%$ ).

Абсолютні похибки бюджетного планування свідчать про те, що з державного бюджету, в цілому, за 2002-2008 рр. було витрачено на 24,2 млрд. грн. більше, ніж було заплановано. Зокрема, на поточні видатки було використано на 99, 1 млрд. грн. більше плану, при цьому капітальні видатки були недофінансовані на 72,0 млрд. грн.

На нашу думку, зазначені факти беззаперечно вказують на відверте соціальне спрямування видаткової частини бюджету та на абсолютне нехтування видатками на економічний розвиток. Вважаємо, наслідком такої бюджетної видаткової політики є перетворення державного бюджету 3 бюджету "розвитку" в бюджет "проїдання". А це, на нашу думку, в умовах сучасної світової фінансової кризи, безсумнівно, є негативним фактором, котрий не сприяє виходу ситуації економічної дестабілізації в країні , а навпаки погіршує ї.

Під час планування бюджету на наступний рік, а також у ході аналізу видатків за попередні роки постає питання про співвідношення темпів зростання номінального ВВП і темпів зростання бюджетних видатків.

\section{Темпи зростання бюджетних видатків відносно попереднього року: фактичні (Ф) і заплановані (П) показники, \%}

\begin{tabular}{|c|c|c|c|c|c|c|}
\hline \multicolumn{2}{|c|}{ Рік } & $\begin{array}{l}\text { Поточні } \\
\text { вид атки }\end{array}$ & $\begin{array}{c}\text { Капіт альні } \\
\text { видатки }\end{array}$ & Видатки & ВВП & Інфля ція \\
\hline \multirow{2}{*}{ ֻิণ } & $\Phi$ & 121,7 & 160,5 & 126,6 & 109,6 & 108,2 \\
\hline & II & 115,0 & 126,6 & 105,0 & 104,8 & 106,5 \\
\hline \multirow{2}{*}{ ষ্ণ } & $\Phi$ & 132,0 & 218,8 & 141,7 & 112,1 & 112,3 \\
\hline & $\Pi$ & 116,5 & 192,5 & 123,2 & 106,0 & 107,6 \\
\hline \multirow{2}{*}{ 气̊̊̆ } & $\Phi$ & 137,1 & 30,5 & 117,0 & 102,7 & 110,3 \\
\hline & П & 136,1 & 216,7 & 148,8 & 106,5 & 108,0 \\
\hline \multirow{2}{*}{ ஓ্ণ } & $\Phi$ & 137,7 & 337,0 & 147,4 & 107,3 & 111,6 \\
\hline & $\Pi$ & 145,4 & 143,4 & 144,8 & 107,0 & 110,3 \\
\hline \multirow{2}{*}{ હิণ } & $\Phi$ & 122,0 & 166,5 & 127,1 & 107,3 & 116,6 \\
\hline & $\Pi$ & 119,5 & 132,8 & 122,5 & 106,5 & 107,5 \\
\hline \multicolumn{2}{|c|}{$\begin{array}{c}\text { Середній темп } \\
\text { зростання } \\
(\Phi)^{*} \\
\end{array}$} & 129,9 & 143,1 & 131,5 & 107,8 & 111,8 \\
\hline \multicolumn{2}{|c|}{ Серед ній темп } & 125,9 & 158,7 & 127,8 & 106,2 & 108,0 \\
\hline
\end{tabular}

*Середні темпи зростання за 2003-2007 pp. розраховано автором за формулою середнього геометричного. 


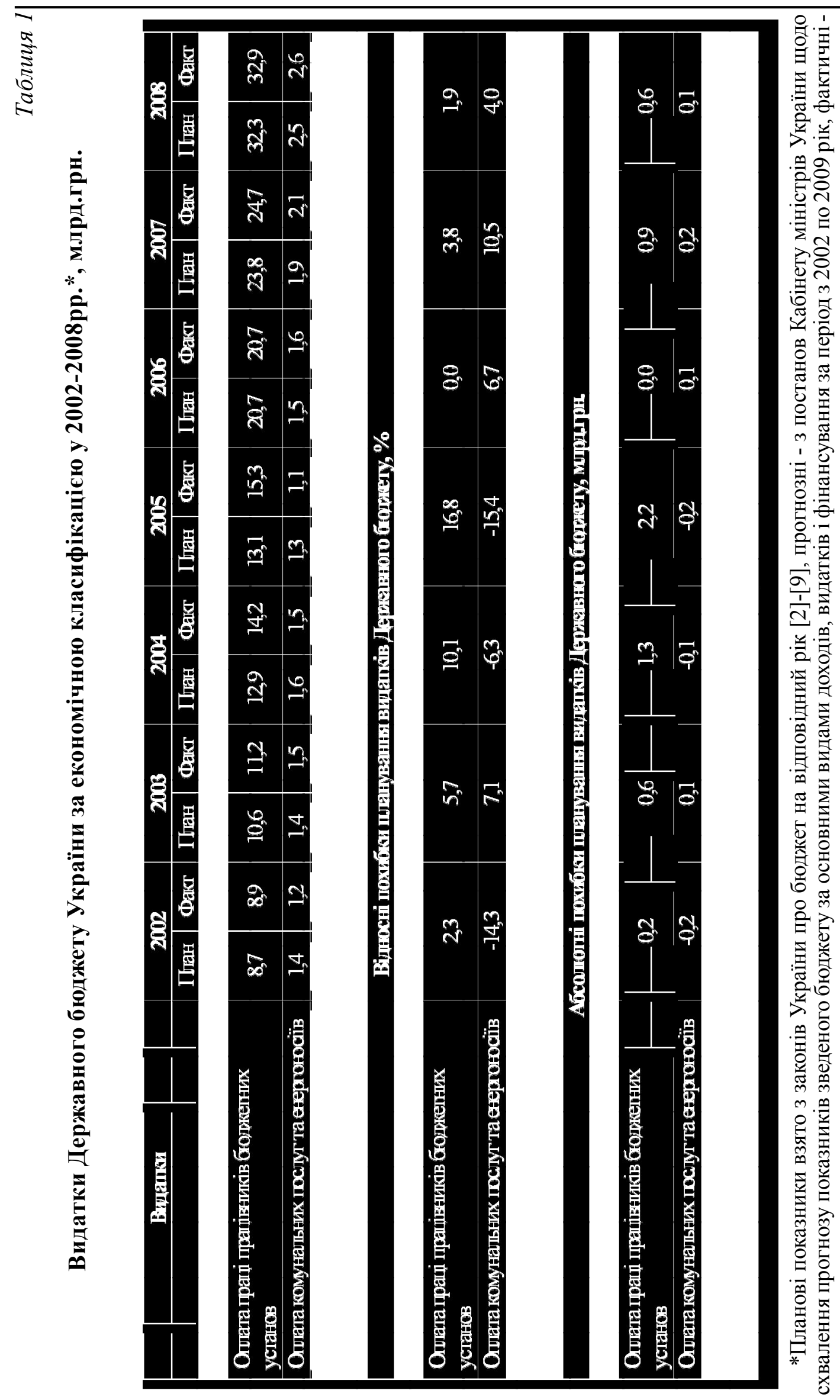


Жебчук Р. Л.

Найбільші фактичні темпи зростання спостерігалися для капітальних видатків у 2006 році, що, в першу чергу пов'язано $з$ дуже низьким рівнем даної статті видатків у 2005 році та різким збільшенням капітальних видатків у 2006 році.

3 таблиці 2 бачимо, що темпи зростання ні фактичні, ні планові не мають постійної, однозначно вираженої тенденції зміни. Водночас усі вони перевищують середній показник зростання номінального ВВП як фактичного $(107,8 \%)$, так i планового $(106,2 \%)$. Аналогічна тенденція спостерігається і відносно середніх показників зростання інфляції. А, в свою чергу, це $\epsilon$ свідченням того, що видатки 3 бюджету держави здійснюються не лише за рахунок інфляційного наповнення бюджету, але й за рахунок і інших джерел.

Для отримання повної картини ефективності планування видатків бюджету необхідним $€$ аналіз якості прогнозування та планування показників зведеного бюджету України. Результуючі показники процесу прогнозування, планування та фактичного виконання зведеного бюджету наведено в таблиці 3.

Прогнозні та фактичні показники зведеного бюджету України на 2003-2008 роки, млрд. грн. * [11, с.22; 13, с. 34]

\begin{tabular}{|c|c|c|c|c|c|c|c|}
\hline $\begin{array}{l}\text { У матеріалах до проекту } \\
\text { державного бюджету на: }\end{array}$ & 2003 & 2004 & 2005 & 2006 & 2007 & 2008 & 2009 \\
\hline \multicolumn{8}{|c|}{2003 рік } \\
\hline Доходи & 64,4 & 73,2 & 82,5 & & & & \\
\hline Видатки & 66,2 & 74,4 & 83,1 & & & & \\
\hline \multicolumn{8}{|c|}{2004 рік } \\
\hline Доходи & & 67,8 & 74,0 & 80,0 & & & \\
\hline Видатки & & 69,0 & 72,6 & 76,8 & & & \\
\hline \multicolumn{8}{|c|}{2005 рік } \\
\hline Доходи & & & 82,4 & 92,4 & 105,0 & & \\
\hline Видатки & & & 82,9 & 92,5 & 105,1 & & \\
\hline \multicolumn{8}{|c|}{2006 рік } \\
\hline Доходи & & & & 113,2 & 130,8 & 147,6 & \\
\hline Видатки & & & & 117,6 & 135,8 & 253,2 & \\
\hline \multicolumn{8}{|c|}{2007 рік } \\
\hline Доходи & & & & & 174,9 & 197,7 & 224,7 \\
\hline Видатки & & & & & 184,6 & 207,8 & 234,0 \\
\hline \multicolumn{8}{|c|}{2008 рік } \\
\hline Доходи & & & & & & 203,9 & 232,1 \\
\hline Видатки & & & & & & 221,1 & 252,3 \\
\hline \multicolumn{8}{|c|}{ Фактичне виконання } \\
\hline Доходи & 75,3 & 91,5 & 132,0 & 171,8 & 219,9 & 297,8 & - \\
\hline Видатки & 75,8 & 101,3 & 141,5 & 175,2 & 226,0 & 309,2 & - \\
\hline
\end{tabular}

*В якості планового показника використано прогнозне значення на відповідний рік згідно матеріалів до проекту державного бюджету цього ж року. За показник середньострокового прогнозу взято перше за хронологією прогнозне значення на відповідний рік.

На основі даних, наведених вище, можна проаналізувати ефективність планування показників зведеного бюджету України (табл.4)

Дані таблиці 4 переконливо свідчать про низьку ефективність оперативного та середньострокового планування показників зведеного бюджету України за 2004-2008 роки. Особливо погана ситуація з середньостроковим плануванням, оскільки тут похибки сягають 120,9 млрд. грн. у абсолютному значенні (2007 рік) та $128,1 \%$ у відносному (2006 рік). Особливо негативний, на нашу думку, той факт, що ситуація 3 кожним роком погіршується.

Отже, сьогодні в Україні існують серйозні недоліки в механізмах середньострокового та поточного бюджетного планування видатків Державного бюджету. У цьому випадку стає зрозумілим той факт, що планові показники бюджету мають абсолютно декларативний характер. Тому за таких умов неможливе проведення послідовної бюджетної політики та побудови перспективної бюджетної стратегії, а отже планування видатків бюджету в Україні, на даний час, здійснюється ситуативно.

Головними перешкодами на шляху повноцінного запровадження технологій бюджетування в Україні є:

- відсутність загальнодержавних і 
Ефективність планування показників зведеного бюджету України за 2004-2008 роки, млрд. грн.

\begin{tabular}{|c|c|c|c|c|c|c|c|}
\hline \multirow{2}{*}{ Рік Пок-к } & \multirow{2}{*}{$\begin{array}{c}\text { Прогноз } \\
\text { (середньостр. } \\
\text { план) } \\
\end{array}$} & \multirow[t]{2}{*}{ План } & \multirow[t]{2}{*}{ Факт } & \multicolumn{2}{|c|}{$\begin{array}{c}\text { Похибка } \\
\text { прогнозування }\end{array}$} & \multicolumn{2}{|c|}{$\begin{array}{c}\text { Похибка } \\
\text { планування }\end{array}$} \\
\hline & & & & абс. & $\%$ & абс. & $\%$ \\
\hline 2004 & 74,4 & 69,0 & 101,3 & 26,9 & 36,2 & 32,3 & 46,8 \\
\hline 2005 & 83,1 & 82,9 & 141,5 & 58,4 & 70,3 & 58,6 & 70,7 \\
\hline 2006 & 76,8 & 117,6 & 175,2 & 98,4 & 128,1 & 57,6 & 49,0 \\
\hline 2007 & 105,1 & 184,6 & 226,0 & 120,9 & 115,0 & 41,4 & 22,4 \\
\hline 2008 & 253,2 & 221,1 & 309,2 & 56,0 & 22,1 & 88,1 & 39,8 \\
\hline
\end{tabular}

регіональних стратегічних орієнтирів розвитку, а також якісного та зрозумілого стратегічного планування на рівні головних розпорядників бюджетних коштів;

- нереформованість більшості галузей економіки, що ускладнює застосування прогресивних технологій бюджетування;

- недостатня обізнаність фахівців провідних державних установ та органів місцевого самоврядування 3 надбанням світової фінансової теорії і практики, української фінансової науки;

- недосконалість управління державним i місцевими бюджетами, форм і методів бюджетного менеджменту, відсутність реального планування і прогнозування бюджету на середнюй довгостроковий періоди на основі новітніх світових бюджетних технологій, які досить успішно застосовуються в Західній Європі.

Для організації високоефективної системи бюджетного планування в Україні доцільно здійснити перелічені нижче заходи.

1. Розробити чітку систему державних програмних і прогнозних документів, на основі яких формується Державний та місцеві бюджети на наступний рік і середньострокову перспективу. Запровадити єдину методику середньострокового бюджетного планування на основі середньострокового прогнозування ресурсної та витратної частин бюджету, а також системи міжбюджетних трансфертів.

2. Здійснити поступові структурні зміни, передусім у соціально-культурній сфері, з метою забезпечення раціонального використання бюджетних коштів.

3. Створити систему оцінювання результативності бюджетних програм на основі безпосередніх показників їх виконання та ефективності діяльності бюджетних установ і організацій, що надають бюджетні послуги, за кінцевими результатами.

4. Запровадити дворівневу структуру програм - підпрограми для комплексного охоплення проблем, що планується розв'язати, та більш гнучкого управління програмами.

5. Удосконалити бюджетну класифікацію в частині програмної класифікації видатків та кредитування бюджету, яка може бути застосована як для Державного, так і для місцевих бюджетів. Розробити ефективний механізм управління коштами в середньостроковій перспективі, а не лише протягом одного бюджетного року. Поетапно запровадити програмно-цільове бюджетування на рівні місцевих бюджетів із метою мінімізації ризиків, пов'язаних із неготовністю як місцевих, так i центральних органів виконавчої влади, до впровадження реформи.

Важливо, що вирішенням частини виявлених проблем функціонування бюджетної системи стане нова редакція Бюджетного кодексу, від 8 липня 2010 року.

Поряд із цим, поступове здійснення запропонованих заходів 3 урахуванням зарубіжного досвіду реформування сфери державного управління дасть змогу обрати та впровадити оптимальний для України шлях трансформації національної системи державних фінансів.

\section{Список літератури}

1. Бюджетний кодекс України // Голос України від 04.08.2010, №143.

2. Закон України "Про Державний бюджет України на 2002 рік" від 20.12.01 p. № 2905-III // Відомості Верховної Ради України. - 2002. - № 12-13.

3. Закон України "Про Державний бюджет України на 2003 рік" від 26.12.02 р. № 380-IV // Відомості Верховної Ради України. - 2003. - № $10-11$.

4. Закон України "Про Державний бюджет України на 2004 рік" від 27.11.03 р. № 1344-IV // Відомості Верховної Ради України. - 2004. - № 17-18.

5. Закон України "Про Державний бюджет України на 2005 рік" від 23.12.04 p. № 2285-IV // Відомості Верховної Ради України. - 2005. - № 78. 
Жебчук Р. Л.

6. Закон України "Про внесення змін до Закону України "Про Державний бюджет України на 2005 рік" та деяких інших законодавчих актів України" від 25.03.05 р. № 2505-IV //Відомості Верховної Ради України. - 2005. - № -18-19.

7. Закон України "Про Державний бюджет України на 2006 рік" від 20.12.05 p. № 3235-IV // Відомості Верховної Ради України. - 2006. - № 911.

8. Закон України "Про Державний бюджет України на 2007 рік" від 19.12.06 р. № 489-V // Відомості Верховної Ради України. - 2007. - № 15-16.

9. Закон України "Про Державний бюджет України на 2008 рік" від 28.12.07 р. № 107-VI // Відомості Верховної Ради України. - 2008. - № 89.

10.Бланкатр Ш. Державні фінанси в умовах демократії: Вступ до фінансової науки/ Пер. $з$ нім. С.О. Терещенко та О.О.Терещенка; за ред. В.М. Федосова. - К.: Либідь. - 2000.
11. Буковинський С.А. Концептуальні підходи до формування перспективного бюджетного плану // Фінанси України.- №3.- 2006.- С.21-28.

12.Бюджетна політика у контексті стратегії соціально-економічного розвитку України: У 6 т. / Редкол.: М.Я. Азаров (голова) та ін. - К.: НДФ1, 2004. - Т. 4: Програмно-цільовий метод у бюджетному процесі / М.Я. Азаров, Ф.О. Ярошенко, 0.1. Амоша (кер. авт. кол.) та ін. - 2004.

13.Затонацька Т.Г., Лаврентьєв М.M. Впровадження середньострокового бюджетного планування як інструмент підвищення ефективності бюджетних видатків// Фінанси України.- №11.- 2007.- С.31-42.

14.Хохич Д.Г. Ефективність системи державних фінансів у контексті інституційного підходу //Фінанси України. - №3.- 2006.- С.65-73.

Аннотация

Роман Жебчук

\section{РЕЗУЛЬТАТИВНОСТЬ ПЛАНИРОВАНИЯ РАСХОДНОЙ ЧАСТИ БЮДЖЕТА КАК ОСНОВА ЭФФЕКТИВНОГО БЮДЖЕТНОГО МЕНЕДЖМЕНТА}

Проанализирована эффективность планирования показателей Государственного и сводного бюджета Украины. Показана необходимость использования качественного метода оиенки эффективности планирования бюджета. Определены главные препятствия на пути полноценного внедрения технологий бюджетирования в стране. Предложены меры по организации высокоэффективной системы государственного бюджетного планирования.

Ключевые слова: бюджет, эффективность планирования, Государственный бюджет Украины, сводный бюджет, государственные расходьл.

\section{Summary}

Roman Zhebchuk

\section{EFFECTIVENESS OF PLANNING OF EXPENDITURES AS A BASIS FOR EFFECTIVE BUDGET MANAGEMENT}

The author examines the effectiveness of State and consolidated budget of Ukraine. Show the necessity of using a qualitative method of evaluating the effectiveness of budget planning. Define the main obstacles to full implementation of technology budgeting in the country. Propose measures that are necessary for high-performance organization system of budget planning.

Key words: budget, the effectiveness of planning, the State Budget of Ukraine, the consolidated budget, public spending. 
УДК 349.3(4/)-10.67.91

(C) Бойко О.В., 2011

Чернівецький національний університет ім. Ю. Федьковича, м. Чернівці

\section{ВПЛИВ МАКРОЕКОНОМІЧНИХ ЧИННИКІВ НА ФУНКЦІОНУВАННЯ ТА РЕФОРМУВАННЯ ПЕНСІЙНОЇ СИСТЕМИ}

Розглянено і проаналізовано макроекономічні чинники (демографічну ситуаџію, інвестиційну політику, витрати державного бюджету) на функиіонування та можливість реформування системи пенсійного забезпечення, закордонний досвід, переваги, недоліки і можливості використання деяких факторів для вдосконалення та підвищення ефективності пенсійного забезпечення Украӥни.

Ключові слова: сочіальна політика, демографічна політика, пенсійний вік, накопичувальна, солідарна і змішана пенсійні системи.

Постановка проблеми. Одним з важливих пріоритетів сучасної соціально-економічної стратегії є ідея економічної забезпеченості гідного життя непрацездатних членів суспільства. Розв'язати цю задачу можна завдяки впровадженню комплексу організаційно-правових i економічних заходів, серед яких важливу роль грають реформування пенсійних систем i створення нових інститутів соціального захисту державної і недержавної форм.

Аналіз останніх досліджень і публікацій. Оскільки дана проблема на сьогодні нагальна, то в економічній літературі їй приділяється досить значна увага. Основні теоретичні основи покращення рівня соціального забезпечення i реформування пенсійної системи розглянуті в роботах таких закордонних дослідників: П. Болла, М. Вінера, Е. Джеймса, Е. Ендрюса, М. Ісаєва, В. Роіка, М. Рутковської, Л. Сичова, В. Хижного, В. Шахова, В. Шерстньова. Серед українських фахівців слід відзначити: С. Бандуру, Д. Богиню, В. Гриньову, В. Грушко, Е. Лібанову, Н. Лук'янченко, А. Макарову, В. Новікова, Ю. Привалова, Ю. Саєнко.

Нерозв'язані раніше частини загальної проблеми. Визнаючи теоретичну і практичну цінність накопичених наукових досягнень, зазначимо, що недостатньо дослідженими залишаються питання формування нових інституціональних структур на зразок закордонних у процесі реформування вітчизняної пенсійної системи та визначення напрямків їх застосування в пенсійній системі України, вплив макроекономічних факторів на процес реформування.

Формулювання цілей статті. Наша держава в процесі реформування системи соціального захисту непрацездатного населення зіштовхнулась 3 певними проблемами, які, на жаль, мають тенденцію до поглиблення і вимагають

змін у ключових напрямках соціального захисту. Серед цих проблем демографічні (депопуляція і старіння населення, збільшення тривалості життя, зниження народжуваності), економічні (безробіття, погіршення пропорції між працюючими і пенсіонерами, ріст навантаження на зайнятих у процесі виробництва); соціальні (бідність у багатій на ресурси країні, недосконалий споживчий кошик). Вплив їх на реформування системи пенсійного забезпечення ми і намагатимемось дослідити.

Викладення основного матеріалу дослідження. Демографічні проблеми насамперед стосуються процесу старіння населення. Він аналізується в економічній літературі з двох сторін: збільшення середньої тривалості життя, що розглядається як позитивне явище, яке призводить до росту частки пенсіонерів, а з іншого боку - збільшення числа осіб, які потребують соціального захисту. Цим загострюється конфлікт між працюючою і непрацюючою частинами населення.

Чисельність населення і його склад $є$ тими факторами, які разом з його платоспроможністю визначають потенційний обсяг спожитих товарів i послуг. Тобто, демографічна ситуація безпосередньо впливає на виробництво, сферу послуг, масштаби експортно-імпортних операцій і в остаточному підсумку відіграє важливу роль у розвитку економіки країни.

На сьогодні демографічний стан України характеризується в такий спосіб: падіння народжуваності, ріст смертності, зменшення міграційного сальдо. Зокрема, у 1991 році смертність в Україні вперше перевищила народжуваність, з 1993-го року почалося зниження абсолютної чисельності населення, а ще через рік сальдо зовнішніх міграцій стало негативним. У результаті за 1993-2006 року чисельність населення України зменшилася на 5,4 млн. осіб і на кінець 2009року склала, за даними Держкомстату України, 46,6 млн. осіб. Така 
Бойко О. В.

тенденція тривала і у 2007-2008 роках. Лише 3 I кварталу 2009 року в чотирьох регіонах було зафіксовано перевищення кількості народжених до кількості померлих. Зокрема у Волинській - на 0,5 відсотка, у Закарпатській - на 2 відсотка, у Рівненській області - на 1 відсоток, у м. Києві - на 7 відсотків. У II кварталі поточного року народжуваність у цих регіонах у співвідношенні до смертності зросла ще більше. Зокрема, у Волинській області кількість народжень на 22 відсотки перевищила кількість померлих, у м. Києві - на 9 відсотків, Рівненській області - на 8 відсотків, Закарпатській області - на 7 відсотків [1].

Дослідження, проведене Світовим банком у 2007 році, прогнозує, що до 2025 року населення України скоротиться на 24\% чи на 12 млн. осіб. Це найгірший показник серед країн Центральної та Східної Європі, а також колишнього СРСР. Таке істотне зменшення чисельності населення нашої країни зв'язано як із природними факторами, так i зі значною еміграцією найбільш продуктивної частини українського суспільства в більш розвиті країни світу (США, Канада, країни Свропи, Росія) [2].

Однак зменшення чисельності населення є не настільки гострою соціально-демографічною проблемою як трансформація його вікової структури, зокрема ріст питомої ваги осіб старших вікових груп. Цей процес, що у науковій літературі одержав назву "старіння населення", з одного боку, може бути закономірним результатом позитивної тенденції - збільшення тривалості життя людей. Але, з іншого боку, високий рівень старіння націй приводить до негативних соціально-економічних наслідків, особливо це стосується країн 3 невисоким рівнем життя, таких, наприклад, як Україна.

Віковий склад населення істотно впливає і на хід демографічних процесів: інтенсивність смертності значно вище серед осіб похилого віку, ніж серед молодих. Відповідно, чим більша питома вага перших у чисельності населення, тим більше необхідно витрачати засобів на підтримку належного соціального рівня забезпечення цієї категорії громадян. Як показує практика, збільшення кількості осіб похилого віку служить причиною росту державних витрат на їхнє соціальне забезпечення.

Дослідженням установлено, що якщо одночасно не збільшується (чи збільшується низькими темпами) кількість платників податків (якими переважно є особи працездатного віку), неминуче зростає податковий тиск. Однак високі податки знижують мотивацію до роботи і іiі продуктивність, що негативно відображається на суспільному добробуті.
За даними світової соціально-демографічної статистики, у період 3 2005-го по 2030 рік пенсійного віку досягнуть люди післявоєнного покоління, на яке прийшовся бум народжуваності. До того ж досить чітко виявляються загальноєвропейські тенденції зниження народжуваності і збільшення тривалості життя. У підсумку, якщо сьогодні особи старше 65-ти років складають 16\% населення Європи, те згідно 3 демографічним прогнозом ООН, до 2030-го року їхня частка виросте приблизно до $25 \%$, а до 2050 року - до $28 \%$.

Як відзначається в дослідженні Світового банку, у 2025 році питома вага громадян у віці більше 65 років буде складати близько $20 \%$ населення України (у 2007 році ця категорія населення нараховувала 14\%). Це ненабагато менше, ніж прогнозується, наприклад, у Словенії (23\%), Хорватії (22\%), Чеській Республіці (22\%), Болгарії (21\%), Угорщині (21\%) і Польщі (21\%). Але є одне "але": у них уже сформувався ринок недержавного пенсійного забезпечення, а в нас почалася лише стадія формування і те, украй повільно.

Навіть тепер рівень пенсійного навантаження досить значний і складає більше 10\% ВВП. У зв'язку з цим Україні міжнародні організації уже рекомендують терміново реформувати пенсійну системи, з метою звести до мінімуму негативні наслідки старіння і скорочення населення. Для цього необхідно прийняти важкі рішення про зменшення державних пенсійних виплат i/чи збільшити вік, при настанні якого така допомога починає виплачуватися, i/чи підвищити розмір пенсійних внесків. При цьому зайняті в даний час працівники понесуть збитки у випадку прийняття кожного 3 цих рішень. Тому владі потрібно заохочувати нинішнє покоління молодих людей планувати заздалегідь свій вихід на пенсію.

В офіційних документах СС установлені конкретні зобов'язання переходу до 2020 року на нові конструкції пенсійних схем. Передбачається, що за цей період частка в пенсійних виплатах солідарної системи знизиться з 84\% до 64\%; трохи зросте накопичувальний компонент - $312 \%$ до $29 \%$, а незначна сьогодні частка добровільного недержавного пенсійного страхування зросте втроє 3 1,5\% до 4,5\%.

Солідарна пенсійна система в Україні має ряд проблем, що загрожують іiі фінансовій стабільності. Діапазон цих проблем широкий - від системної складності до погрози того, що можна чекати в 2055 році: на одного працівника в Україні буде припадати 1,42 пенсіонера. На думку Світового банку, незважаючи на прийняття основних законодавчих актів, трирівнева система не була впроваджена через брак інституціональної 
й адміністративної бази.

На відміну від інших країн, де передбачені значні податкові пільги для учасників недержавних пенсійних фондів і страхувальників, вітчизняні підприємці знаходяться перед вибором "чи - чи": чи довгострокове страхування життя, чи недержавне пенсійне забезпечення. Як результат, сьогодні питома вага пенсійних актів недержавних пенсійних фондів і страхових резервів компаній по страхуванню життя до ВВП України складає лише $0,15 \%$. Це становить всього 1\% від активів Пенсійного фонду України. При таких обставинах нашу країну в найближчому майбутньому очікує криза не тільки пенсійного забезпечення, а насамперед ускладнення демографічної ситуації i погіршення макроекономічних показників розвитку, тому що значна частина державна бюджету буде спрямована на покриття дефіциту солідарної системи пенсійного забезпечення.

3 огляду на досвід інших країн, для України досить складним інструментом розв'язання проблеми пенсійного забезпечення є збільшення віку виходу на пенсію. Це питання почало вирішуватися з моменту підписання у серпні 2010 року меморандуму з Міжнародним валютним фондом. Ціна питання - \$15,3 млрд. кредиту.

Так, заради цих грошей восени в Раду повинен бути внесений законопроект, у якому передбачене поступове збільшення пенсійного віку для жінок 3 55 до 60 років (починаючи з 2010 року щорічно буде додаватися по 6 місяців). Також збираються збільшити на 10 років (до 15 років) мінімальний страховий стаж, що дає право на половину мінімальної пенсії (у жовтні 2010 року це 361,5 грн. на місяць), а для того щоб мати право на повноцінну пенсію за віком, чоловікам доведеться працювати 35 років (зараз 25 років), а жінкам 30 років (зараз 20) [3].

Ці умови жорсткіші, ніж планувалося. Спочатку пенсійний вік збиралися підвищувати починаючи з 2012 року і тільки для тих жінок, які народилися після 1964 року.

Поки що всі ці нововведення - на рівні проекту, однак, з огляду на те, що гроші МВФ потрібні Україні конче, практично немає сумнівів що депутати внесуть необхідні зміни в законодавство.

Дана міра повинна була б поліпшити збалансованість Пенсійного фонду на цілих 2 млрд. грн. вже в 2011 році, однак підвищення пенсійного віку на наповнення ПФ можуть і не вплинути, оскільки корінні проблеми лежать у мізерній ціні праці, занижених державою розмірах прожиткового мінімуму та мінімальної зарплати. Звідси і низькі відрахування в ПФ. Виходить, можна працювати хоч 20, хоч 40 років, але пенсія від цього більшою не стане.

Хоча підвищення пенсійного віку є вимогою
МВФ ы передбачає покращення ситуації 3 видатками на пенсійне забезпечення, однак може негативно вплинути на соціальний стан суспільства. За даними Інституту демографії та соціальних досліджень НАН України, на сьогодні чоловіки-українці в середньому живуть 62 року, а жінки - 74 роки. Для порівняння, пенсійний вік у Японії для обох статей - 70 років, а середня тривалість життя 82 року [4]. У США працюють до 65, а живуть у середньому 78 років. В Франції виходять на відпочинок у 62 року з половиною, а вмирають у 80. Виходить, багатьом нашим співгромадянам прийдеться заробляти на жадану пенсію ледве не все життя, оскільки європейський фонд нав'язує нам свою стандартну програму заходів, що, на його думку, автоматично поліпшить економічне становище України. За словами експертів, так не буде: час, що хочуть відвести українкам на працю не відповідає відрізку життя, що залишиться їм на відпочинок, оскільки наша жінка в 55 відповідає 65-літній європейці по стану здоров'я в зв'язку з хворобами, екологією, навантаженням, умовами праці. МВФ же не бере до уваги ні позицію профспілок, ні особливості країни, якій він дає рекомендації. Тому питання підвищення пенсійного віку 3 одного боку $є$ необхідним кроком для підвищення ефективності функціонування системи пенсійного забезпечення, однак, можливо, застосовувати такий підхід в умовах кризових явищ та вкрай складної економічної ситуації на Україні $\epsilon$, на сьогодні, недоцільним.

Можливо, більш прийнятним зараз було б запровадження економічних стимулів для пізнішого виходу людей на пенсію шляхом прогресивного підвищення розміру пенсії за кожен рік праці після досягнення пенсійного віку. Це дозволило б зняти навантаження 3 Пенсійного фонду, яке зумовлене досить високими темпами зростання кількості пенсіонерів в Україні.

Іншими чинниками, які б могли пришвидшити та правильно побудувати процес реформування системи пенсійного забезпечення $є$ розробка програми реформування економіки, що буде виводити українське суспільство 3 прірви бідності, убогості і неповноцінності, створення умов для росту економічної стабільності, побудова соціально справедливої і прозорої фінансової системи, розробка ефективно функціонуючого Податкового кодексу, зниження темпів росту цін, прозора політика з кредитування людей і бізнесу.

Для виконання покладених завдань необхідно здійснити ряд досить складних заходів:

- зменшити рівень перерозподілу ВВП через бюджет і позабюджетні фонди (зараз він складає $42,4 \%)$ до рівня, принаймні, $36 \%$, що дозволить підвищити вище темпи економічного росту, та 
Бойко О. В.

зменшить рівень корупції і тіньової економіки;

- розробити Податковий кодекс, який максимально справедливо розподіляв би рівні оподаткування доходів різних категорій населення, скасував би граничну межу оподаткування сум заробітної плати, пропагував прозорий та справедливий процес оподаткування;

- провести усі необхідні процедури для забезпечення відповідних умов здійснення правильної політики інвестування;

- забезпечити функціонування ефективної та надійної банківської системи;

- створення умов для підтримки малого i середнього бізнесу [5].

Після створення сприятливого економічного середовища, появи в Україні середнього класу, підвищення рівня життя населення можливим буде проведення реформування пенсійної системи, дієздатність якої напряму залежить від рівня життя працездатного населення та можливостей держави.

Важливим моментом на шляху до підвищення ефективності функціонування системи пенсійного забезпечення та можливості їі подальшого реформування є створення єдиного страхового внеску на загальнообов'язкове державне соціальне страхування 3 метою уникнення дублювання функцій окремих фондів соціального страхування [6].

Висновки та перспективи подальших досліджень.

Взагалі, пенсійна реформа має здійснюватися на системних засадах, перевірених досвідом інших країн та адаптованих до українських умов, а саме:

- соціальної справедливості, прийнятності, розуміння та підтримки реформи широкими верствами населення;

- свободи вибору, підвищення зацікавленості і відповідальності громадян за свій добробут у старості;

- економічної обгрунтованості та фінансової спроможності стійкості пенсійної системи;

- сприяння зростанню національних заощаджень та економічному розвитку країни;

- захищеності від політичних ризиків.

Внаслідок здійснення реформи буде впроваджено багаторівневу пенсійну систему, побудовану на засадах соціальної справедливості, солідарності поколінь та соціального страхування. Це розширить можливості для підвищення добробуту людей похилого віку та зміцнення потенціалу економічного зростання [7, с.6-7].

Створення адекватної ринковій економіці пенсійної системи підвищить рівень відповідальності громадян за свою долю, спонукатиме їх залишати частину зароблених коштів на старість, допоможе подолати патерналістські настрої та очікування, швидше адаптуватися до нових умов життя.

Здійснення пенсійної реформи дасть змогу подолати бідність серед людей похилого віку, які все життя добросовісно працювали і створювали національне багатство.

Також досить актуальним є питання чіткого $\mathrm{i}$ прозорого контролю за діяльністю органів Пенсійного фонду і функціонуванням пенсійної системи. Тому необхідно створити механізми надійного контролю суспільства й держави за функціонуванням пенсійної системи. Важливою складовою успішного i повноцінного функціонування пенсійної системи є іï інформаційне забезпечення. Система інформування, роз'яснення сенсу проведених реформ має стати основною ланкою в процесі перетворень пенсійної системи [8].

Необхідно забезпечити звільнення Пенсійного фонду від невластивих йому функцій. Зокрема, передати недержавним пенсійним фондам функції 3 пенсійного страхування працівників тих галузей, які на сьогодні мають пільги при призначенні пенсій. Потрібно впровадити накопичувальну систему загальнообов'язкового державного пенсійного страхування, провести модернізацію матеріально-технічної бази. В перспективі можна передбачити і здійснення доставки пенсій. Це дозволило б зосередити в органах Фонду усі функції пенсійного страхування - від збору страхових внесків і призначення пенсій до їх доставки пенсіонерам.

Звичайно, ці заходи будуть ефективними за умови забезпечення професійного росту i кваліфікації працівників Фонду, підвищення дисципліни і якості роботи. Тому, саме роботі 3 кадрами, підвищенню їх професійного рівня необхідно надалі приділяти особливу увагу. Для цього необхідно продовжити практику навчання молоді у вищих навчальних закладах за направленнями Пенсійного фонду та змінити підхід до продовження роботи кваліфікованих досвідчених кадрів пенсійного віку.

Врахування всіх недоліків і вад системи пенсійного забезпечення України та їх вирішення дасть змогу сформувати розвинений ринок послуг 3 цього виду страхування. Отже, позитивними результатами у покращенні пенсійного забезпечення України має стати досягнення таких результатів: забезпечення фінансової стійкості та стабільності у сфері пенсійного страхування; зменшення кількості пільговиків; підвищення рівня життя пенсіонерів та впевненості у соціальному забезпеченні; зменшення пенсійного навантаження роботодавців; створення результативної системи управління пенсійними 
грошовими потоками; заохочення громадян до заощаджень на старість; встановлення чіткого законодавства.

За умови здійснення вище названих заходів пенсійне забезпечення в поєднанні із соціальною допомогою сформують набагато надійнішу систему захисту від бідності, ніж та, яка існує сьогодні.

Проте, якщо зміни буде запроваджено тільки в пенсійній системі, то виявлені проблеми навряд чи вдасться усунути. Пенсійна реформа має стати складовою частиною комплексної програми економічних і фінансових перетворень.

\section{Список літератури}

1. www.ck.ukrstat.gv.ua

2. Галина Третякова forINSURER.com (по мат. журнала "Страховий рейтинг "Insurance Top" 25.02/2008)

3. Меморандум України та Міжнародного валютного фонду, підписаний 12.08.2010

4. Олексій Іващенко. Про підвищення пенсійного віку. Щотижневик 2000, № 24 (514), 1824.06.2010

5. Олександр Савченко. Макроекономічна політика-слабка ланка реформ. Дзеркало тижня, № 24 (804), 26.06.-02.07.2010

6. М. Шаповал, О. Коцюба, В. Ніколаєнко, Ю. Резнікова. Дослідження впливу запровадження накопичувальної складової державної системи пенсійного страхування на підвищення рівня соціального захисту населення в Україні. Журнал "Соціальний захист", №12, Грудень 2005

7.Тетяна Гурик. За внесками єдиний. Вісник Пенсійного фонду України № 9 (99), 2010, с.6-7

8. Іващук С. С. Проблеми пенсійного забезпечення. Прагматика та шляхи вдосконалення. www.rusnauka.com/.../ 66976.doc.htm

\section{Аннотация}

Ольга Бойко

\section{ВЛИЯНИЕ МАКРОЭКОНОМИЧЕСКИХ ФАКТОРОВ НА ФУНКЦИОНИРОВАНИЕ И РЕФОРМИРОВАНИЕ ПЕНСИОННОЙ СИСТЕМЫ}

Рассмотрено и проанализировано макроэкономические факторы (демографическую ситуацию, инвестиционную политику, затраты государственного бюджета) на функционирование и возможность реформирования системы пенсионного обеспечения, заграничный опыт, преимущества, недостатки и возможности использования некоторых факторов для усовершенствования и повышения эффективности пенсионного обеспечения Украины.

Ключевые слова: сочиальная политика, демографическая политика, пенсионный возраст, накопительная, солидарная и смешанная пенсионные системы.

\section{Summary}

Olga Boyko

\section{IMPACT OF MACROECONOMIC FACTORS ON THE FUNCTIONING AND REFORM THE PENSION SYSTEM}

The article reviews and analyzes the macroeconomic factors (demographic, investment policy, spending the state budget) for the operation and the possibility of reforming the pension system, foreign experience, advantages, disadvantages and have some of the factors for the improvement and efficiency of pension provision in Ukraine.

Keywords: social policy, population policy, retirement age, accumulation, and mixed PAYG pension systems. 


\section{ОСОБЛИВОСТІ ВАЛЮТНОГО КУРСОУТВОРЕННЯ В УКРАЇНІ}

Стаття присвячена аналізу тенденцій валютного ринку в Україні, а також факторів, щяо мали вплив на процес валютного курсоутворення. Запропоновано заходи, необхідні для стабілізаиії валютного ринку та запобігання різких курсових коливань.

Ключові слова: кредитний курс, валютне регулювання, валютна політика, ревальвація, валютна інтервенція, валютний ринок, платіжний баланс, зовнішній борг.

Вихід України з фінансово-економічної кризи супроводжувався помірною волатильністю валютного ринку. Різка девальвація гривні наприкінці 2008 p. - початку 2009 р. трансформувалася у відносну стабільність курсу національної валюти у подальшому періоді. Попри те, що були всі передумови для подальшого ослаблення гривні, центральному банку країни, завдяки доволі раціональному здійсненню валютних інтервенцій та ряду інших заходів, все ж вдалося втримати курс в межах 7,95-8,05 грн./ дол. США. У 2010 р. реалізація валютної політики Національним банком супроводжувалася нарощенням активів вітчизняною банківською системою та відновленням реального сектору економіки. Проте наприкінці минулого року можна було спостерігати вже й негативні тенденції, що безумовно матимуть вплив на стан валютного ринку України в поточному 2011 р., а тому потребуватимуть застосування ефективного механізму валютного регулювання.

Метою статті $€$ дослідження валютнокурсових коливань української гривні в 2010 р., а також факторів, що здійснювали вплив на процес курсоутворення в Україні.

Теоретичні та практичні проблеми встановлення валютного курсу досліджувалися у працях як вітчизняних, так і зарубіжних науковців. Серед вітчизняних науковців можна виділити роботи Ю. Бездідько, С. Боринця, Ф. Журавки, Я . Белінської, Б. Лапчука, А. Філіпенко та ін. Серед зарубіжних науковців заслуговують уваги праці Джеймса В. Діна, Д. Кідуелла, Р. Петерсона, Д. Блекуелла.

Протягом 2010 р. офіційний номінальний курс гривні дещо зміцнився з 7,98 грн./дол. до 7,96 грн./ дол. або на $0,29 \%$. Посилення офіційного курсу гривні щодо євро та російського рубля становило $7,65 \%$ та $1,05 \%$ відповідно. Незначна ревальвація гривні ззовні характеризує стабільність на вітчизняному валютному ринку й адекватну політику Національного банку. Проте більш значимим, 3 огляду на довгострокову макроекономічну політику держави, $є$ визначення того, чи ця стабільність тривала, які кон'юнктурні зміни мають вплив на обмінний курс гривні та як здійснювати його подальше регулювання.

Незважаючи на відсутність різких коливань на готівковому валютному ринку України у минулому році, тенденції останніх місяців залишалися не зовсім втішними. Починаючи із вересня 2010p. обсяг продажу іноземної валюти вітчизняними банками перевищував обсяг купівлі більше ніж вдвічі. Загалом, за результатами 2010 p., обсяг продажу валюти банківськими установами становив 25,3 млрд. дол. США, тоді час як обсяг купівлі складав всього лише 16,6 млрд. дол. США. Різниця між обсягом попиту та пропозиції валюти з боку населення становила 8,7 млрд. дол. США.

Зазначимо, що попит на іноземну валюту формує як населення країни, так і суб'єкти тіньового сектору економіки, які здійснюють свої розрахунки переважно в іноземній валюті. Тому, причиною такого значного розриву валютного попиту та пропозиції на готівковому ринку $є$, насамперед, недовіра до вітчизняної валюти 3 боку населення та підвищення ділової активності суб'єктів тіньової економіки. Як бачимо, попри відносну стабілізацію номінального курсу гривні та банківської системи загалом, виважену грошово-кредитну політику центрального банку країни у частині формування грошової маси, пожвавлення реального сектора економіки, у минулому році не доводилося спостерігати підвищення довіри до національної валюти. Це пов'язано, передусім, із інфляційними та девальваційними очікуваннями населення.

Зростаючий попит на іноземну валюту створює передумови до підвищення рівня доларизації як банківської системи, так і економіки країни в цілому. Так, за підсумками 2010 р., частка депозитів у іноземній валюті в загальній структурі депозитного портфеля українських банків складала 42,6\%, тоді як у передкризовий 2007 р. ця частка була на рівні $32,3 \%$. Рівень доларизації 
української економіки, розрахований за методикою МВФ, у 2010 р. становив 29,7\%, тоді як у 2007 р. - 23,4\%[2].

Значний обсяг депозитів у іноземній валюті міг би бути потужним кредитним ресурсом для банківського сектору. Проте, впродовж усього 2010 р., діяла заборона НБУ на здійснення валютного кредитування фізичних осіб. Пояснюється це тим, що фізичні особи наражаються на великі ризики неповернення кредитних боргів в умовах девальваційних очікувань, оскільки власні доходи вони отруюють переважно у вітчизняній валюті. Це означає, що значні запаси іноземної готівки в банках, залучені через депозитні механізми не можуть бути спрямовані на кредитування реального сектора економіки. У подібній ситуації логічним видається або встановлення заборони на проведення депозитних операцій банками в іноземній валюті, або скасування заборони валютного кредитування. Заборона на відкриття валютних депозитних рахунків вкрай небезпечна для економіки країни, насамперед, через зростання обсягів іноземної валюти поза банківською системою, що неодмінно призведе до розвитку тіньового валютного ринку і зменшення рівня керованості процесу курсоутворення з боку центрального банку. Тому залишається лише очікувати відновлення валютного кредитування, яке повинне супроводжуватися впровадженням модернізованої системи аналізу платоспроможності банківських клієнтів.

Упродовж 2010 р. динаміка торгів на міжбанківському валютного ринку України була різноспрямованою. У перші місяці через зменшення надходжень від експортерів при одночасному збільшенні платежів за імпортними контрактами спостерігався дефіцит іноземної валюти, що спричиняв тиск на гривню та вимагав від НБУ проведення регулярних інтервенцій із продажу валюти. Проте вже з середини лютого надходження іноземної валюти в країну почали перевищувати перекази на користь нерезидентів, що позитивно позначилось на збільшенні ii пропозиції на міжбанківському валютному ринку та на зміцненні курсу національної валюти.

Стабілізація ситуації на валютному ринку дала можливість НБУ здійснювати інтервенції з купівлі іноземної валюти, поповнюючи міжнародні резерви. Починаючи з березня, вперше після серпня 2008 р. Нацбанк мав додатне сальдо валютних інтервенцій. У березні - серпні воно становило в еквіваленті 5,1 млрд. дол. США. Проте 3 вересня ситуація знову змінилася в бік стійкого домінування попиту на іноземну валюту, а НБУ був змушений здійснювати інтервенції зіі продажу. У вересні - грудні від'ємне сальдо валютних інтервенцій дорівнювало 2,2 млрд. дол. США (у грудні - 0,6 млрд. дол. США). Водночас за результатами 2010 р. сальдо валютних інтервенцій Національного банку було додатним i становило 1,3 млрд. дол. США, тоді як у 2009 р. воно було від'ємним і складало 10,4 млрд. дол. США [3].

Позитивне сальдо валютних інтервенцій сприяло зростанню обсягів міжнародних резервів у 2010 р. на 30,5\% до рівня 34,6 млрд. дол. США. Крім валютних інтервенцій НБУ, на їхню динаміку вплинуло надходження кредитних коштів від російського ВТБ Банку у сумі 2,0 млрд. дол. США, двох траншів МВФ розміром 3,4 млрд. дол. США, розмішення облігацій зовнішньої державної позики, a також здійснення платежів із погашення та обслуговування зовнішнього державного та гарантованого державою боргу. За цих умов курс гривні до долара США на міжбанківському валютному ринку зріс на $0,38 \%$ і на кінець року становив 796,17 грн. за 100 дол. США.

Завдяки стабілізації ситуації на валютному ринку та зменшення різниці між офіційним i міжбанківським курсом гривні до долара США 3 березня 2010p. НБУ призупинив проведення цільових аукціонів з продажу іноземної валюти для задоволення потреб клієнтів банків - фізичних осіб 3 метою погашення ними заборгованості за валютними кредитами.

Ситуація на готівковому та міжбанківському валютному ринках відображає зміни причиннонаслідкових факторів, які залежать від динаміки економічного зростання, рівня інфляції, зміни обсягу грошової маси, стабільності банківського сектору, політичної складової і т.д. Проте одним iз найбільш визначальних факторів установлення рівноваги на валютному ринку будь-якої країни $\epsilon$ стан платіжного балансу, що відображає співвідношення між загальним обсягом валютних платежів, які сплачуються господарюючими суб'єктами даної країни суб'єктам в інших країнах, та сукупними валютними надходженнями, що характеризують зворотний рух валютних цінностей.

У 2010 році дефіцит поточного рахунку розширився до 2,9 млрд. дол. США у порівнянні 3 2009p., коли дефіцит становив 1,7 млрд. дол. США. Від'ємне сальдо торгівлі товарами в 2010 р. збільшилось до 8,7 млрд. дол. США (4,3 млрд. дол. США в 2009 р.). Таке погіршення відбулося, насамперед, за рахунок значної енергетичної складової української економіки. Якщо не брати до уваги торгівлю енергоносіями, то баланс товарів залишався майже на рівні попереднього року. А додатне сальдо торгівлі послугами збільшилось до 4,9 млрд. дол. США з 2,4 млрд. дол. США в 2009 р., переважно за рахунок 
підвищення тарифів на транспортування газу.

Вкрай важливий той факт, що в другій половині 2010 р. намітилася чітка тенденція погіршення сальдо рахунку поточних операцій за рахунок як збільшення негативного сальдо торгівлі товарами, так і скорочення додатного сальдо торгівлі послугами. Так, якщо в I та II кварталах 2010 р. спостерігався профіцит поточного рахунку у розмірі 57 та 495 млн. дол. США відповідно, то уже в III та IV кварталах склався дефіцит на рівні 1,1 та 2,3 млрд. дол. США.

Рахунок операцій $з$ капіталом у 2010 р. склався 3 профіцитом - 187 млн. дол. США, в основному за рахунок продажу квоти на викиди вуглекислого газу в III кварталі 2010 р. Що стосується фінансового рахунку платіжного балансу, то в цілому за 2010 р. профіцит склався у розмірі 7,7 млрд. дол. США, в той час як за результатами 2009 р. сальдо за цим рахунком було від'ємним (12,6 млрд. дол. США)[6].

Аналогічно рахунку поточних операцій, сальдо рахунку операцій з капіталом і фінансових операцій також мало тенденцію до погіршення у другій половині минулого року. Якщо у II кварталі 2010 р. позитивне сальдо складало 4,6 млрд. дол. США, то у III і IV кварталах воно зменшилося до 3,2 та 0,9 млрд. дол. США відповідно. І це при тому, що в III та IV кварталах було отримано чергові транші від МВФ за кредитом stand-by на загальну суму 3,4 млрд. дол. США (з них українським урядом було отримано 2,0 млрд. дол. США)[7]. Основною причиною такої невтішної ситуації стало нарощення обсягів готівкової іноземної валюти поза банківською системою країни, в основному через зростання недовіри населення до вітчизняних банківських установ та активізацією операцій на тіньовому валютному ринку.

Зрозуміло, що стан поточного рахунку та рахунку операцій з капіталом і фінансових операцій відобразився на стані платіжного балансу загалом. Попри негативну динаміку наприкінці року, Україні все ж вдалося вийти на позитивне сальдо зведеного балансу, яке, за підсумками 2010 p., склало 5,0 млрд. дол. США. Основними факторами формування додатного сальдо (більше це стосується сальдо рахунку операцій з капіталом і фінансових операцій) можна назвати: по-перше, наявність вільної ліквідності на світових фінансових ринках на фоні поступового відновлення економічного зростання; по-друге, політична стабільність в Україні та успішна співпраця 3 міжнародними фінансовими організаціями. Наслідками цього стало зростання обсягів прямих іноземних інвестицій в економіку України, а також залучення іноземних кредитних ресурсів з боку як державного сектора, так i приватного.
Істотний вплив на значення обмінного курсу гривні чинять зміни обсягів грошової маси країни в національній валюті, які потенційно можуть бути конвертовані в іноземну та які посилюють чи послаблюють інфляційні процеси в країні. Починаючи 3 лютого 2010 р., крім незначного сезонного зниження в листопаді, обсяги грошової маси демонструють помісячний приріст. Загалом, за підсумками 2010 р. обсяги грошової маси збільшилися на 22,7\%, тоді як протягом 2009 р. спостерігалося зменшення на 5,5\%. Як результат, на кінець 2010 р. вони складали 598,4 млрд. грн. Приріст грошової бази у 2010 р. виявився, навпаки, меншим, ніж у попередньому році і складав 4,6\% та $10,6 \%$ відповідно[5].

Динаміка зовнішньої торгівлі країни та стан їі платіжного балансу залежить не стільки від змін офіційного обмінного курсу валюти, скільки від зміни реального ефективного курсу, при визначенні якого враховується ще й рівень інфляції в країні порівняно $з$ країнами - основними торговельними партнерами. Очевидним є той факт, що зростання рівня інфляції забезпечує вищу норму рентабельності імпортних поставок і, як наслідок, стимулює імпортну діяльність країни. А підвищення загального рівня цін в країні безумовно спричиняє зростання витрат виробництва для експортерів, що робить їхню продукцію неконкурентоспроможною.

Протягом 2010 р. відбувалося уповільнення індексу цін споживачів, приріст якого за результатами 2010 р. вперше 32003 р. знизився до однознакового рівня - 9,1\% порівняно $312,3 \%$ у 2009 році, а його показник у грудні $(0,8 \%)$ був найнижчий за аналогічний період за всю історію статистичних спостережень 31991 р. До слова, варто зазначити, що рівень інфляції наприкінці року хоча й був рекордно низьким, проте залишається доволі високим у порівнянні 3 іншими країнами 3 якими Україна має тісні торговельні зв'язки.

Саме високий рівень інфляції зумовив те, що реальний ефективний обмінний курс гривні у 2010 p. зріс порівняно з 2009 р. на 8,7\%. При цьому номінальний ефективний обмінний курс гривні посилився на 4,9\% через іiі зміцнення відносно валют країн - основних торговельних партнерів України[5]. Ревальвація реального ефективного курсу вітчизняної валюти у минулому році, безумовно, впливатиме на посилення негативної динаміки поточного рахунку платіжного балансу і у першій половині 2011 р.

Як видно з аналізу основних чинників впливу на процес валютного курсоутворення в Україні, наприкінці 2010 р. виник ряд передумов щодо посилення тиску на курс гривні в бік ії подальшого послаблення. 3 метою стабілізації валютних відносин як на готівковому так і на 
ОСОБЛИВОСТІВАЛЮТНОГО КУРСОУТВОРЕННЯ В УКРАЇНІ

міжбанківському валютному ринку та уникнення курсових коливань доцільними були б наступні заходи:

1) Відновлення кредитування в іноземній валюті, так як це дасть змогу вітчизняним банківським установам використати акумульовані валютні кредитні ресурси та зміцнити свій фінансовий стан. Це стане вагомим кроком на шляху відновлення довіри до банківської системи 3 боку населення, що, по-перше, посилить керованість монетарною системою 3 боку центрального банку країни, а, по-друге, завдяки зменшенню обсягу готівкової іноземної валюти поза банківською системою, позитивно вплине на стан фінансового рахунку платіжного балансу. Негативним аспектом даного заходу може стати те, що левова частка валютних кредитів буде спрямована на виконання імпортних контрактів та повернення позикових коштів, залучених 3-за кордону у попередніх періодах.

2) Лібералізація режиму валютного курсоутворення. Світовий досвід переходу від фіксованого до плаваючого валютних курсів вказує на різні наслідки для країн, що вдалися до такого заходу. Проте в середньостроковій та довгостроковій перспективі подібна трансформація режиму курсоутворення, здебільшого, забезпечує меншу вразливість країни до внутрішніх та зовнішніх шоків, більшу незалежність грошово-кредитної політики, а також саморегуляцію платіжного балансу та валютного курсу, внаслідок взаємозалежних змін.

Іншим важливим моментом лібералізації курсоутворення є скасування прив'язки до долара США, тому що в умовах фіксації курсу підвищується залежність від стану економічного розвиту країни, до валюти якої здійснюється прив'язка національної валюти. В умовах нещодавньої світової кризи, яка розпочалася саме в США та майбутньої кризи, яку прогнозує МВФ це $\epsilon$ досить небезпечним. Тому Україні варто орієнтуватися не на одну валюту, а на своєрідний кошик валют (аналогічно встановленню МВФ курсу СПЗ), що буде відображати більш об'єктивні зміни на світових валютних ринках.

3) Диверсифікація золотовалютних резервів. Орієнтація на полівалютний кошик вимагає від НБУ диверсифікації золотовалютних резервів для адекватного реагування центрального банку на курсові коливання та мінімізації валютних ризиків. Значне превалювання однієї валюти у структурі резервних активів, внаслідок різкої волатильності валютного ринку, може враз спустошити їх, залишивши центральний банк країни без вагомого регулятивного важеля - валютних інтервенцій, а національну валюту - без надійного захисту від обвального падіння.
4) Утримання рівня інфляції в поточному році в десятивідсотковій зоні. Це надзвичайно важливо 3 огляду на необхідність ліквідації дефіциту зовнішньоторговельного балансу, що можливо за умови помірної девальвації реального ефективного обмінного курсу гривні. Високі темпи інфляції в країні роблять експортну продукцію неконкурентоспроможною, а саму експортну діяльність подекуди, навіть, збитковою. Важливою передумовою ефективної антиінфляційної політики $\epsilon$ помірне зростання грошової маси, що не має значно перевищувати темпи зростання реального ВВП країни.

5) Зменшення рівня дефіцитності державного бюджету за рахунок детінізації економіки та розширення податкової бази, а також забезпечення функціонування Пенсійного фонду України та НАК "Нафтогаз України" на беззбитковій основі. Значний рівень дефіциту бюджету (6\% від ВВП у 2010р. при безпечному значенні у $3 \%$ ), звичайно, відлякує як потенційних закордонних інвесторів, так і звичайних торговельних партнерів у контексті платоспроможності держави. Крім того, постійний дефіцит бюджету приводить в дію емісійний механізм і провокує зростання й без того значного обсягу державного боргу.

Підводячи підсумки, зазначимо, що протягом 2010 р. українська гривня ревальвувала по відношенню до американського долара, до якого здійснюється прив'язка у процесі курсоутворення, на 0,29\%. Реальний ефективний обмінний курс зріс аж на 8,7\%. Безумовно, така ситуація не могла не позначитися на динаміці зовнішньоторговельних операцій. Так, наприкінці минулого року вже можна було спостерігати збільшення рівня дефіциту торговельного балансу паралельно зменшенню профіциту фінансового рахунку платіжного балансу. Подібні зміни спричинили зростання розриву між попитом та пропозицією на іноземну валюту на користь попиту як на міжбанківському валютному ринку, так і на готівковому. Можна констатувати, що в країні виник ряд передумов щодо посилення тиску на курс гривні в бік іiі подальшого послаблення. Ефективність подальшої валютної політики багато в чому буде залежати від того, чи піде Нацбанк на рішучі кроки по лібералізації режиму валютного курсоутворення та умов функціонування валютного ринку.

\section{Список літератури}

1. Бездідько Ю. М. Валютне регулювання [Текст] : навч. посіб. / Ю. М. Бездідько, О. О. Мануйленко, Г. А. Стасюк. - Херсон : ОЛДІ-плюс, 2004. - 272 с.

2. Береславська О. Курсова політика в Україні: тенденції та перспективи / О. Береславська // Вісник 
Ткач С. В.

Національного банку України. - 2011. - №2 - С. 10-15 3. Бюлетень Національного банку України // Національний банк України. - 2011. - № 2. - С. 20-21.

4. Журавка Ф. О. Валютно-курсова політика Національного банку України в умовах трансформаційної економіки [Текст] : монографія / Ф. О. Журавка. - Суми : Ділові перспективи ; УАБС НБУ, 2007. - 70 с.

5. Офіційний сайт Національного банку України [Електронний ресурс]. - Режим доступу: URL : http:/ /bank.gov.ua. - Назва з екрану.
Платіжний баланс України // Платіжний баланс і зовнішній борг України. 2010 рік. - К. Національний банк України, 2011. - С. 3-56.

7. Про стан платіжного балансу України у 2010 році: аналіт. записка / Національний банк України // [Електронний ресурс]. - Режим доступу: URL : http:/ /www.bank.gov.ua/Publication/econom/Balans/ State.pdf.

8. Смирнов С. Режимы валютного курса и стабильность экономики // Вопросы экономики. 2010. - № 1. - С. 35-37.

\section{Аннотация}

Сергей Ткач

\section{ОСОБЕННОСТИ ВАЛЮТНОГО КУРСООБРАЗОВАНИЯ В УКРАИНЕ}

Статья посвящена анализу тендениий валютного рынка в Украине, а также факторов, оказавших влияние на проиесс валютного курсообразования. Предложены меры, необходимые для стабилизачии валютного рынка и предотвращения резких курсовых колебаний.

Ключевые слова: кредитный курс, валютное регулирование, валютная политика, ревальвация, валютная интервенщия, валютный рынок, платежный баланс, внешний долг.

\section{Summary}

Sergiy Tkach

\section{FEATURES OF THE EXCHANGE RATE IN UKRAINE}

The article is dedicated to the analysis of currency market tendencies in Ukraine and also factors that had an impact on the exchange rate. The necessary measures for stabilizing of currency market and prevention of sharp course fluctuations are offered.

Keywords: credit rate, currency regulation, monetary policy, appreciation, currency intervention, currency market, the balance of payments, external debt. 


\title{
МАРКЕТИНГ
}

\author{
УДК 65.05 \\ (C) Кошкаров С.A., 2011 \\ Чернівецький кооперативний економіко-правовий колледж, м. Чернівці
}

\section{ЕКОНОМІЧНИЙ АНАЛІЗ ОСНОВНИХ ОЗНАК ЧИННОГО КООПЕРАТИВНОГО ЗАКОНОДАВСТВА}

Кооперативи створюються для служіння своїм членам $i$ за своєю природою відрізняються від підприємств, орієнтованих на отримання прибутку. У більшості держав кооперативи юридично належать до неприбуткових організачій. На відміну від інших неприбуткових організацій. кооперативи мають право розподіляти між членами отриманий прибуток (чистий дохід). Особлива природа кооперативів може бути успішно зреалізована при yfkt;yjve законодавчому забезпеченні і у відповідному економічному середовищі.

Ключові слова: економіка, кооперація, виробництво, підприємство, прибуток, закон, споживач, ресурси.

Постановка проблеми. Об'єктивні процеси ринкових перетворень в економічній системі України, реалізація стратегії переходу до ефективної соціально-орієнтованої ринкової економіки, подолання кризових явищ і досягнення економічного зростання України загалом, та кооперативних систем зокрема, закономірно вимагають адекватного нормативно-правового забезпечення їх діяльності.

Соціально-економічну суть кооперації і проблеми юридичної практики досліджували видатні вчені минулого: М. Туган-Барановський, О. Чаянов, А. Меркулов, М. Хейсин та інші. Сьогодні - це праці Саблука П.Т., Апопія В.В., Башняніна Г.І., Ботушанського В.М., Молдован Л.В., Бачинського В.І., Куцика П.О., Рекрута В.П., В. Гончаренка, В. Зіновчука, М.Алімана А.Пантелеймоненка та багатьох інших науковців. Публікації цих авторів присвячені економічному аналізу тільки окремих кооперативних законів, практики їх застосування 3 відповідними висновками.

Метою даної статті є розгляд есіх спеціальних кооперативних законів, прийнятих за роки незалежності України, за певними економічними ознаками.

Викладення основного матеріалу дослідження. Згідно зі ст. 36 Конституції України. громадяни "мають право на свободу об'єднання у політичні партії та громадські об'єднання для здійснення і захисту своїх прав і свобод та задоволення політичних, економічних, соціальних, культурних та інших інтересів" [1, с.10]. Реалізація, зокрема, прав соціально-економічного благополуччя формалізується через прийняті в Україні спеціальні кооперативні закони: "Про споживчу кооперацію" [2], "Про сільськогосподарську кооперацію" [3] , "Про кооперацію" [4], "Про кредитні спілки" [5].

Задекларована нами мета може бути досягнута через співставлення трактувань у цих законах певних економічних визначень. Аналіз чинного кооперативного законодавства України за основними ознаками наведено у таблиці 1.

3 таблиці можемо зробити такі висновки.

До п.1. Найбільш повно визначення мети створення кооперативів наведено у ЗУ "Про кооперацію". Виробничі ж сільськогосподарські кооперативи створюються "на засадах підприємництва з метою отримання прибутку".

До п.2. Українські кооперативні принципи співставимо 3 принципами, визначеними Міжнародним кооперативним альянсом: добровільне та відкрите членство; демократичний членський контроль; економічна участь членів; автономія і незалежність; освіта, підвищення кваліфікації та інформація; співробітництво між кооперативами; турбота про громаду. 


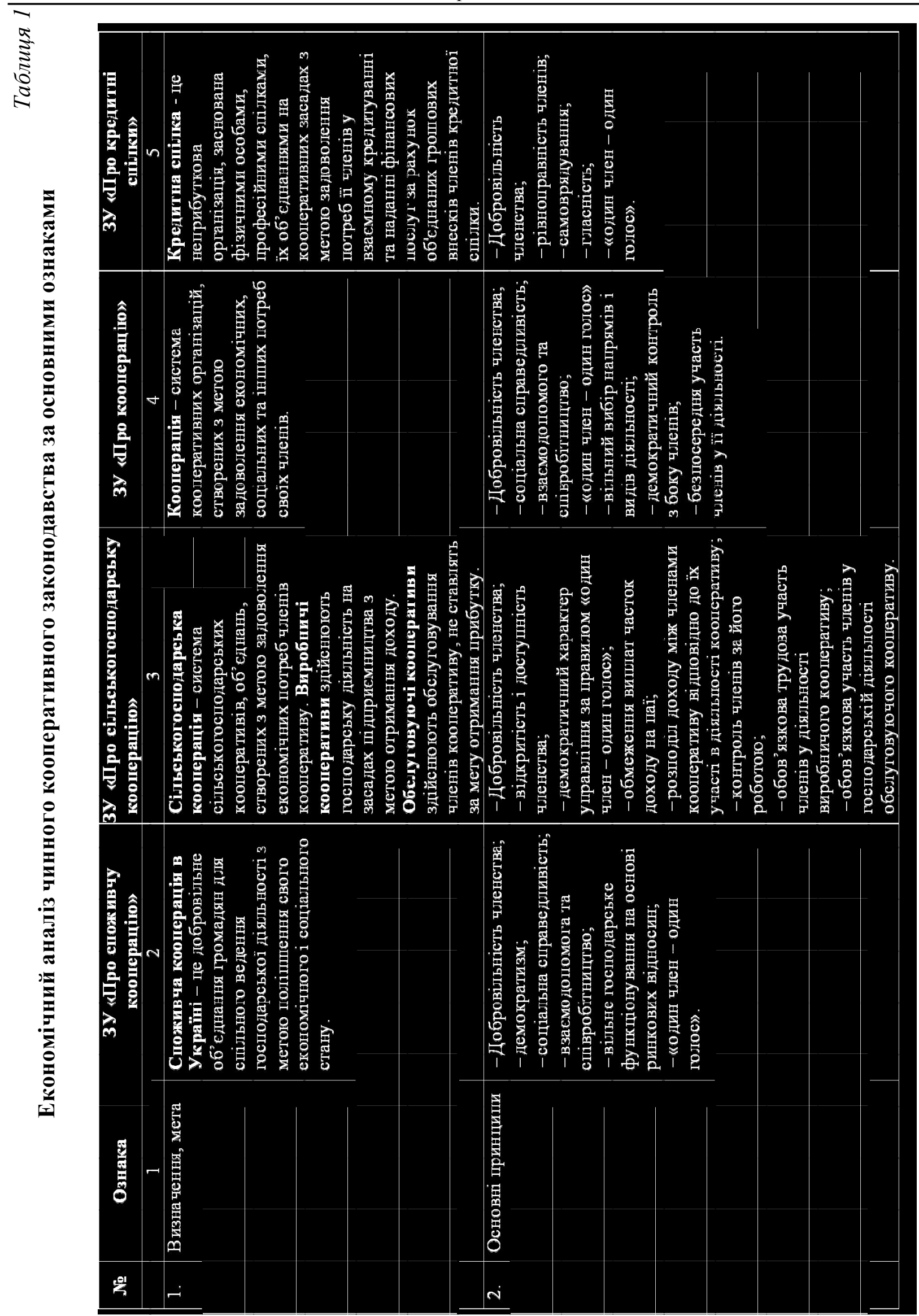




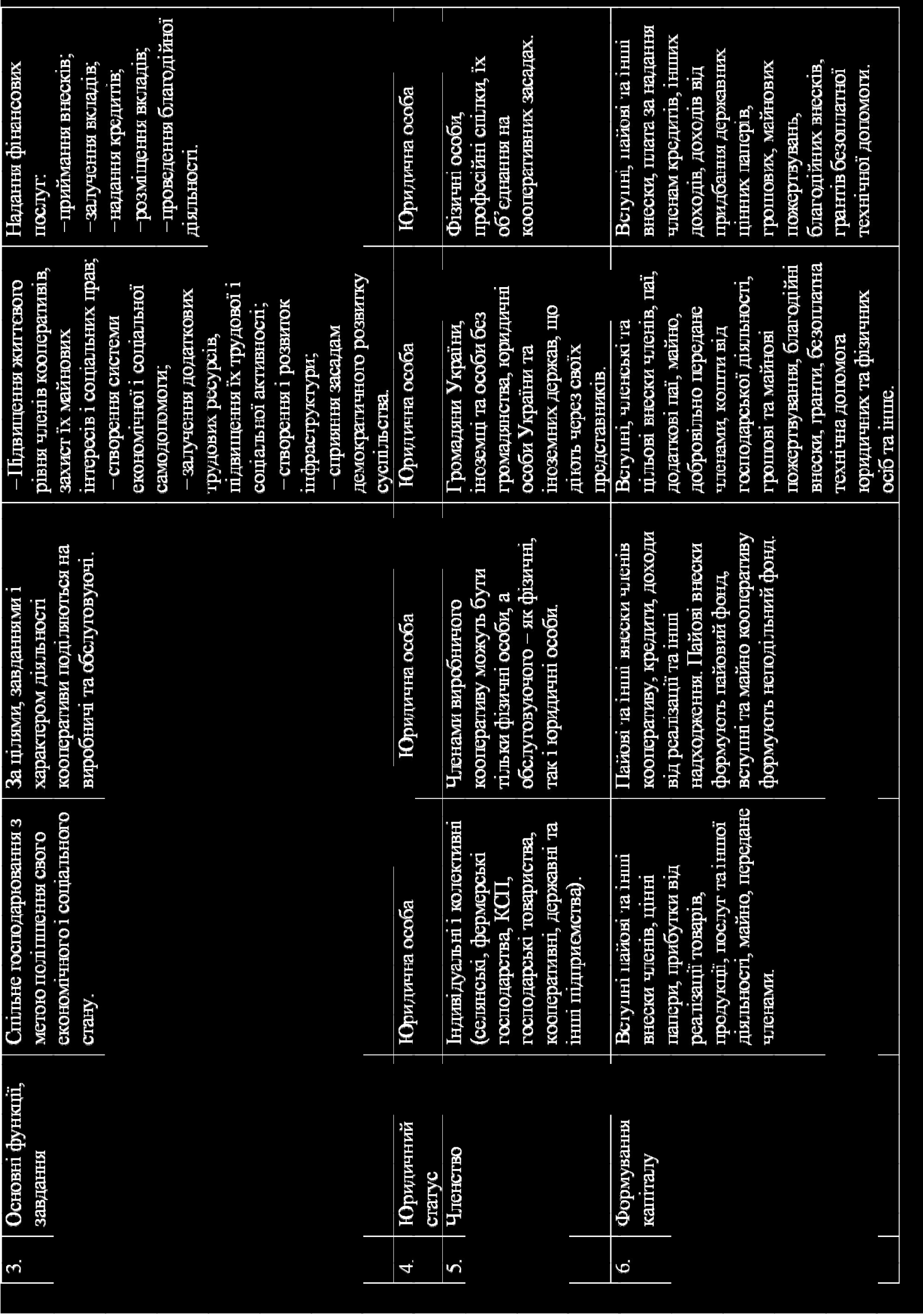




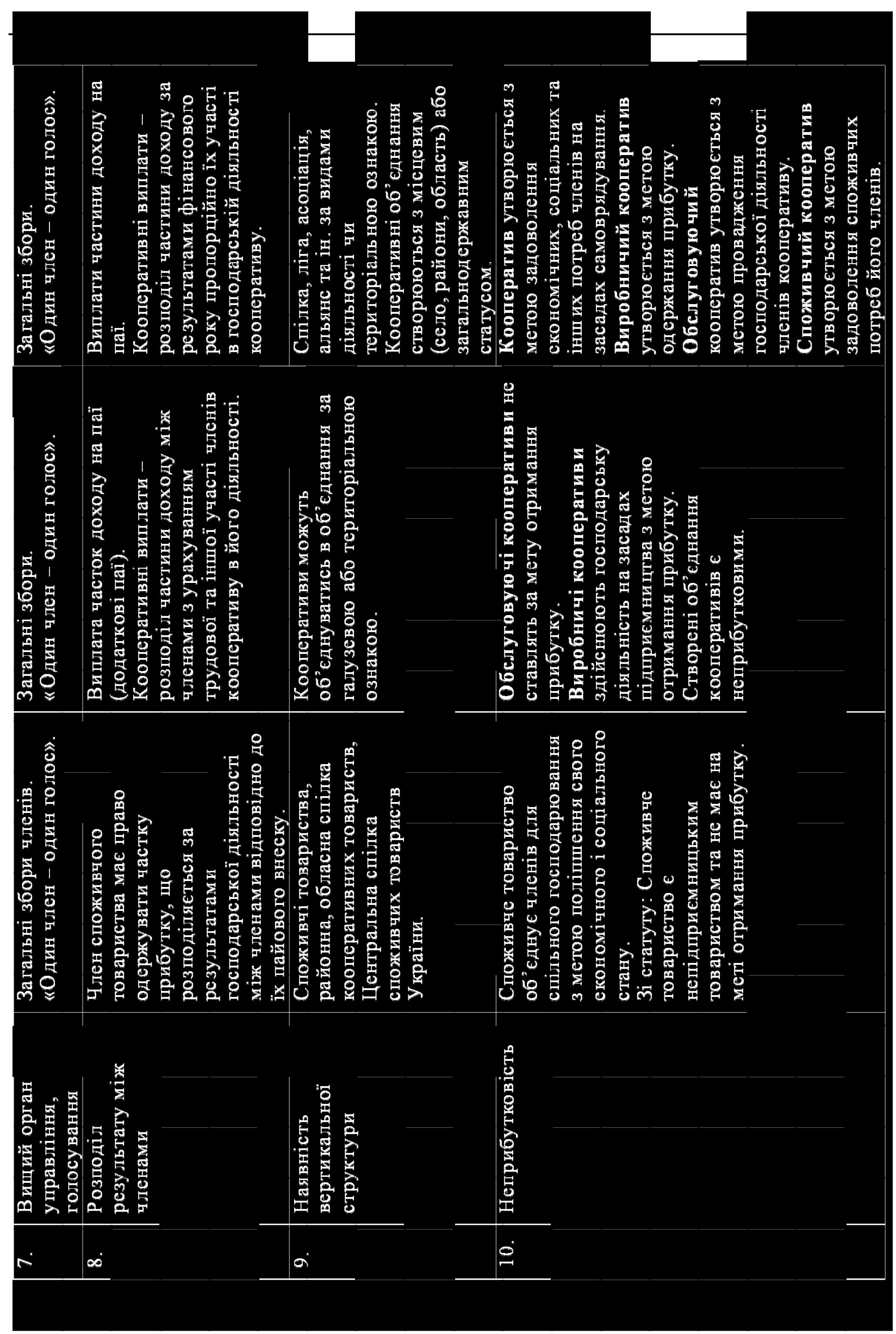



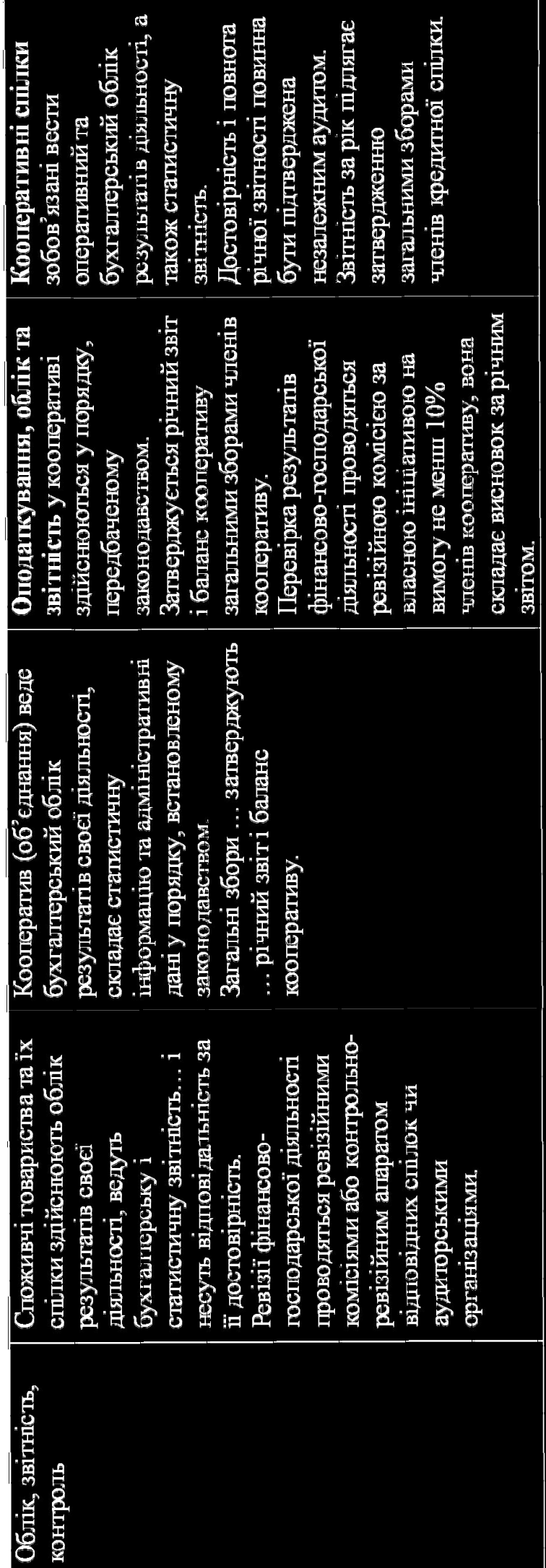
Кочкаров С. A.

До п.6. Кооперативи в Україні, як правило, створюються i функціонують на засадах самофінансування. Інші надходження (фінансові, майнові) мають характер благодійництва. Фінансова стимулююча і регулююча роль держави законодавчо не закріплена.

До п.7. Принцип "один член - один голос", притаманний кооперативним підприємствам, підкреслює їх демократичну, рівноправну, соціальну спрямованість та мету неприбутковості і відрізняється від інших господарюючих суб'єктів, де розподіл голосів здійснюється відповідно до частки в капіталі, кількості акцій, паїв тощо.

До п.9. За період з 1993 року в Україні створена розгалужена система кредитних спілок: функціонує 678 кредитних спілок, 24 обласних та 3 всеукраїнських асоціації.

Сучасна сільськогосподарська кооперація розвивається з 1997 року. Обласних об'єднань кооперативів не створено, а Національна спілка сільськогосподарських слаборозвинута в інституційному плані.

На державному рівні існує Союз сільськогосподарських обслуговуючих кооперативів, перед яким стоїть завдання лобіювання проекту Закону України "Про сільськогосподарську обслуговуючу кооперацію".

Тільки споживча кооперація має чітко вибудувану потужну багаторівневу кооперативну систему на рівні села, району, області і Центальну спілку споживчих товариств України.

До п. 10. Метою утворення кооперативів $\epsilon$ задоволення економічних, соціальних та інших потреб членів на засадах самоврядування, тобто не отримання максимального прибутку, а максимальне задоволення потреб своїх членів на неприбуткових засадах через спільну діяльність. Чинне українське законодавство неоднозначно або вибірково трактує права різних видів кооперативів на неприбутковість. Наприклад, незважаючи на те, що у Примірному статуті споживчого товариства чітко визначено, що воно "є непідприємницьким товариством та не має на меті отримання прибутку" [6, с.38], Податковий кодекс України статус неприбутковості однозначно визначає тільки для кредитних спілок [7, c.248].

Згідно зі ст. 3 Господарського кодексу України (ГКУ), "Господарська діяльність, що здійснюється $з$ метою одержання прибутку, $є$ підприємництвом. Господарська діяльність ... без мети одержання прибутку - некомерційна господарська діяльність" $[8$, с.5]. Некомерційне господарювання - це самостійна систематична господарська діяльність, спрямована на досягнення економічних, соціальних та інших результатів без мети одержання прибутку.
Головною ознакою, яку використано в ГКУ для розмежування комерційної та некомерційної господарської діяльності, є відсутність мети одержання прибутку. Тому автори вищезгаданого науково-практичного коментаря ГКУ вважають, що є категорія неприбуткових організацій (господарюючих суб'єктів) - суб'єкти некомерційної господарської діяльності (некомерційного господарювання), передбаченої главою 5 першого розділу ГКУ: "ними, для прикладу, $\epsilon$... споживчі та обслуговуючі кооперативи, кредитні спілки ..." [8, с.226].

До п.11. Облік і звітність у кооперативах у значній мірі залежить від статусу неприбутковості.

Виробничі ж сільськогосподарські кооперативи, в яких "сума, одержана від реалізації сільськогосподарської продукції власного

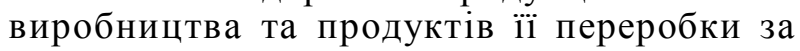
попередній звітний (податковий) рік, перевищує 75 відсотків загальної суми валового доходу" [9], мають право оплачувати фіксований сільськогосподарський податок (в рахунок окремого переліку податків і зборів, зокрема, податку на прибуток).

у більшості передових країн світу кооперативи мають особливий правовий статус неприбуткових (non profit). На 64 сесії Генеральної Асамблеї ООН було прийнято резолюцію "Кооперативи в процесі соціального розвитку", а 2012 рік проголошено Міжнародним роком кооперативів.

\section{Список літератури}

1. Конституція України. - К.: Офіційне видання Верховної Ради України, 1996. - 52 с.

2. Закон України "Про споживчу кооперацію" від 10.04.1992 р. № 2265-XII.

3. Закон України "Про сільськогосподарську кооперацію" від 17.07.1997 р. № 469/97-ВР.

4. Закон України "Про кооперацію" від 19.12.2000 p. № 1348/2000.

5. Закон України "Про кредитні спілки " від 20.12.2001 p. № 2908-III.

6. Довідник інструктора організаційнокооперативної роботи. - К.: Видавничий дім "Комп'ютерпрес", 2007. - 432 с.

7. Податковий кодекс України: чинне законодавство станом на 10 грудня 2010 року. К.: Алерта; ЦУЛ; 2011. - 584 с.

8. Господарський кодекс України. Науковопрактичний коментар. / За ред. Коссана В.М. К.:Алерта; ЦУЛ; 2010. - 672 с.

9. Закон України "Про фіксований сільськогосподарський податок" від 17.12.1998 р. № 320 - XIV. 


\section{ЭКОНОМИЧЕСКИЙ АНАЛИЗ ОСНОВНЫХ ПРИЗНАКОВ ДЕЙСТВУЮЩЕГО КООПЕРАТИВНОГО ЗАКОНОДАТЕЛЬСТВА}

Кооперативы создаются для служения своим членам и по своей природе отличаются от предприятий, ориентированных на получение прибыли. В большинстве государств кооперативы юридически принадлежат к неприбыльным организациям. В отличии от других неприбыльных организаций кооперативы имеют право распределять между членами полученную прибыль (чистый доход). Особенная природа кооперативов может быть успешно реализована при соответствующем законодательном обеспечении и соответственной экономической среде.

Ключевые слова: экономика, кооперация, производство, предприятие, прибыль, закон,, право, потребитель, ресурсы .

\section{Summary}

Stepan Koshkarov

\section{THE ECONOMY ANALYSIS OF THE APPLICABLE COOPERATIVE LEGISLATION FEATURES}

Cooperatives are created to serve its members and by nature differ from enterprises oriented on profit-making. In most countries cooperatives are legally non-profit organizations. In contrast to other non-profit organizations cooperatives enjoy the right to distribute the profit earned (net profit) to a cooperative's members. The especial nature of cooperative societies can be successfully realized at corresponding legislative maintenance and the respective economic environment.

Key words: economy, cooperation, production, enterprise, profit, law, consumer, resources. 
УДК 681.3.07

(C) Струлєв O.O., 2011p.

Національний університет Украӥні "Київський Політехнічний Інститут", м.Київ

\section{ЖИТТЕВИЙ ЦИКЛ ОБ'ЄКТІВ ПРОМИСЛОВОЇ НЕРУХОМОСТІ ЯК ТОВАРІВ ПРОМИСЛОВОГО РИНКУ}

Показано, що кожний ринок товарів, в тому числі промисловий, кожен сегмент ринку промислових товарів, в тому числі й ринок промислової нерухомості відповідає окремому життєвому ичиклу. Життєвий ичикл об'єкта нерухомості повністю детермінований поведінкою його власника i всі фактори впливу змінні. Незмінні фактори випливають з природної специфіки об'єктів нерухомості як, наприклад, неможливість перенесення об'єкта нерухомості в інше місие, де існує незадоволений попит, не можуть бути реалізовані. Підсумовано, що традииійна форма життєвого ииклу як залежності обсягу продаж від часу може застосуватись в основному до компаній виробників об'єкта нерухомості, тобто до виду товару, а не до самого товару.

Ключові слова: життєвий иикл, об'єкт нерухомості, товар, продаж, рентабельність.

Постановка проблеми. Життевий цикл товару не залежно від його виду, за визначенням провідних фахівців 3 теорії маркетингу $[1,3]$ це динаміка зміни обсягу продажу товару відповідного виду, отримання прибутку протягом відповідного відрізку часу від надходження товару на ринок до його зникнення. Для цього використовують запозичену з біології $\mathrm{S}$ - подібну логічну криву з чотирма явно вираженими циклами - введення товару на ринок, зріст - турбулентність, зрілість-насиченість, спадок - завершення.

Має місце детальний, поглиблений погляд на проблему. Жан-Жак Ламбен у [2] стверджує, що в визначенні поняття "життєвий цикл товару" багато неоднозначного і неконкретного. Він ставить під сумнів правомірність застосування цього поняття до усіх без винятку товарів тільки на тій підставі, що обсяг продажу товару з часом змінюється. Ламбен пропонує застосувати це визначення винятково для характеристики життєвого циклу ринку товарів, де товар розглядається не як матеріальна субстанція, а як набір специфічних властивостей адресованих для задоволення потреб окремої групи споживачів. Таким чином, кожний ринок товарів, в даному разі промисловий ринок, а також кожен сегмент ринку промислових товарів, в тому числі і ринок промислової нерухомості, відповідає окремому життєвому циклу. Такий підхід найбільше відповідає визначенню життєвого циклу такого специфічного товару, як нерухомість. При такому підході життєвий цикл відображає не стільки еволюцію товару, скільки еволюції попиту, тобто еволюцію ринку для якого він призначений. Це в значній мірі може бути віднесено до таких специфічних товарів промислового ринку, як об'єкти промислової нерухомості. Еволюцію попиту на ринку промислової нерухомості доцільно розглядати не відносно окремого об'єкту, як конкретного виду товару, а відносно окремого класу товарів, наприклад об'єкти нерухомості для роздрібної торгівлі, складські приміщення, виробничі об'єкти нерухомості і т.п. Але у зв'язку 3 невідривністю від конкретного розташування об'єктів промислової нерухомості попит на такий товар є суто регіональний, і пов'язаний, в основному, з наявністю його на ринку. В одних регіонах є попит на об'єкти промислової нерухомості відповідного функціонального призначення, але він не може бути задоволений в зв'язку з відсутністю таких об'єктів на ринку. В іншому регіоні на ринку представлені об'єкти промислової нерухомості відповідного функціонального призначення, але відсутній попит.

У першому випадку, це може бути визвано обмеженістю земельних ділянок, як основної складової об'єктів промислової нерухомості. Достатньо в той чи інший спосіб розв'язати цю проблему, наприклад шляхом викупу та знесення застарілих або зношених об'єктів нерухомості і побудови на звільненій земельній ділянці виробничого комплексу відповідно наявному попиту, як попит буде задоволений на довгі роки, а може і назавжди. В іншому випадку наявність на промисловому ринку нереалізованих об'єктів нерухомості може бути продиктована не його насиченістю таким товаром, а відсутністю попиту в зв'язку з економічною або політичною ситуацією, наприклад депресивністю того чи іншого регіону. У разі зміни загальної економічної чи політичної ситуації на краще, ті один або декілька об'єктів, що "імітували" на ринку промислових товарів, уже декілька років, його насиченість, будуть стрімко реалізовані і попит на об'єкти промислової 
нерухомості відповідного функціонального призначення перейде $з$ стану насичення, в стан зростання.

Об'єкти промислової нерухомості як товари промислового ринку кількісно досить обмежені. Мова йде про наявність на регіональних ринках промислової нерухомості (ринки промислової нерухомості суто регіональні) десятків, в таких визначних регіонах як Київський, Харківський, Донецький, можливо, сотень об'єктів нерухомості. Що не йде ні в яке порівняння з іншими товарами промислового ринку: мільйонами одиниць цегли, сотнями тисяч тонн цементу, металу інших матеріалів, комплектуючих виробів і сировини.

Аналіз останніх досліджень та публікацій. Ринок промислової нерухомості в Україні існує більше 10 років. Основні дослідження цього періоду стосуються в основному формування та розвитку ринку нерухомості [4], формування регіональних ринків [5], вивчення проблеми оцінки об'єктів нерухомості [6], процесів і ролі ринку в перехідній економіці країни [7], стрімкого розвитку окремих сегментів ринку нерухомості [8]. Такі наукові дослідження були спрямовані на розв'язання тих нагальних економічних проблем, без чого саме існування такого ринку було б неможливе.

Нерозв'язані раніше частини загальної проблеми. У зв'язку з досить коротким періодом існування ринку промислової нерухомості в Україні, загальною кількістю публікацій стосовно цього напрямку економічної наукової діяльності не може бути достатньо. Національна економічна наука набула стрімкого зросту, але й досі відчутна обмаль досліджень 3 науково-теоретичної сутності такого економічного явища як нерухомість. Тому важко виділити із загальноіснуючих економічних та товарних характеристик і факторів базові, що витікають 3 природних, родових ознак об'єктів промислової нерухомості. Дефіцит наукових досліджень локального ринку, праць в даному питанні призводить до труднощів в формуванні професійного бачення середовища та території, де необхідно діяти, а також самого предмету дії.

Мета статті. Стаття присвячена дослідженню одного 3 факторів - динаміки процесів, що супроводжують об'єкти промислової нерухомості впродовж всього періоду їх існування та перебування на ринку промислових товарів.

Викладення основного матеріалу дослідження. Об'єкти промислової нерухомості - це складний багатоелементний та специфічний товар, як в створенні так і використанні. Об'єкти нерухомості створюються за індивідуально розробленими проектами з конкретною прив'язкою до земельної ділянки та місцевості, тобто як фізичний реально існуючий предмет, об'єкт промислової нерухомості суто індивідуальний і навіть унікальний. В той же час, 3 точки зору господарського використання об'єкти промислової нерухомості повинні мати можливість забезпечення широкого спектру їх функціонального призначення. У господарській діяльності об'єкти нерухомості можуть використовуватись як у вигляді окремих будівель або споруд, так і в комплексі з ряду будівель, що складають цілісні господарські комплекси. Цілісний господарський комплекс - це комбінація двох або більше будівель (приміщень), розташованих на одній земельній ділянці, які функціонують в єдиному господарському процесі, виробничому або комерційному процесі, відокремлення яких неможливе без нанесення шкоди загальному господарському процесу. В майновому відношенні цілісний господарський комплекс може належати одному власнику та мати обмеження щодо його поділу, тобто бути цілісним у володінні, або не бути обмеженому в поділі, а знаходитись під одним управлінням.

Ми встановили, що об'єкти промислової нерухомості мають потрійну сутність: фізичну, економічну та правову.

Фізичну - протягом усього періоду існування об'єкт промислової нерухомості зберігає свою натурально-майнову форму.

Економічну - протягом усього періоду існування об'єкт промислової нерухомості зберігає свою економічну форму, як предмет економічних відносин. Як товар об'єкт промислової нерухомості $є$ реальним фінансовим активом для його власника. Призначений для виробничого або комерційного призначення об'єкт промислової нерухомості для інвестора є капіталом, який може приносити прибуток від оренди або продажу, тобто $\epsilon$ різновидом фінансового активу.

Правову - протягом усього періоду існування об'єкт промислової нерухомості є суб'єктом права, яка передбачає його державну реєстрацію при зміні власника, реконструкції або ліквідації.

Сутність об'єктів промислової нерухомості протягом всього періоду існування проходить зміни під дією внутрішніх та зовнішніх факторів впливу: природних, технічних, фізичних, економічних, соціальних, політичних, моральних та інших. Якщо ми зможемо визначити зміни, що відбуваються під впливом факторів впливу 3 фізичною, економічною та правовою сутністю об'єктів промислової нерухомості, ми побудуємо теоретичну модель відповідних життєвих циклів об'єктів промислової нерухомості. Деякі з таких моделей життєвого циклу нерухомості розглянені в [9].

Упродовж періоду існування кожен об'єкт промислової нерухомості проходить такі чотири 
Струлєв О. О.

стадії існування, або життєвого циклу фізичного існування:

Створення - придбання земельної ділянки, будівництво будівель або споруд, покращення, обладнання, введення в експлуатацію.

Експлуатація - функціонування за цільовим призначенням, розвиток, зміна виду використання, капітальний ремонт, реконструкція, санація, банкрутство, модернізація, реорганізація, ліквідація та інше;

Зміна власника, орендаря, користувача - ці зміни неодноразово відбуваються протягом періоду експлуатації об'єкта нерухомості. Кожний раз при таких змінах об'єкт нерухомості може стати товаром, якщо він буде представлений на загальнодоступний конкурентний ринок.

Закінчення існування будівель або споруд - це може відбутись природним шляхом (розвал у зв'язку з природним старінням), результатом стихійного лиха, або в результаті відповідного рішення власника.

Закінчення існування будівель або споруд не приводить до повної ліквідації об'єкта нерухомості, як товару, а лише змінює його статус. Оскільки основною складовою кожного об'єкту нерухомості є земля, а земля незнищувальна. Тому після знесення всього того, що було побудовано, або знаходилось на поверхні землі та було нерозривно 3 нею пов'язано, земельна ділянка стає вільною від забудови і в правому відношенні має статус, об'єкта нерухомості - земельна ділянка відповідного цільового призначення і може бути представлена на ринку промислових товарів, як товар.

У кожній із чотирьох стадій існування об'єктів промислової нерухомості існує певний проміжок часу, протягом якого 3 ним відбуваються певні еволюційні зміни під тиском зовнішніх і внутрішніх факторів впливу. Найбільш тривала стадія експлуатації об'єкта промислової нерухомості. Упродовж цього періоду об'єкт промислової нерухомості ефективно використовується за своїм функціональним призначенням і приносить дохід. Цей період згідно 3 [10] підпорядковується відповідним закономірностям і має, визначенням Г. Харрисона, такі терміни (строки) існування: економічний, фізичний, хронологічний та залишковий строк економічного життя.

Економічний строк життя - це період прибуткового використання об'єкта нерухомості. Якщо власник об'єкту нерухомості буде своєчасно проводити поточний та капітальний ремонти об'єкта нерухомості, відповідно зі зміною технології, технологічного процесу, соціальних i культурних вимог, зміною навколишнього середовища вносити поліпшення до об'єкту нерухомості, проводити переобладнання, а в разі нагальної необхідності і реконструкції термін економічного життя об'єкта може бути продовжено на значний термін до 100, 200 і більше років. Кінець економічного життя об'єкта нерухомості наступає тоді, коли поліпшення об'єкту нерухомості вже не можуть бути реалізовані та не вносять вагомого внеску у вартість об'єкта нерухомості у зв'язку з його суцільним зношенням.

Фізичний строк життя - це період реального існування об'єкта нерухомості 3 моменту його створення (реєстрації, введення в експлуатацію) до моменту представлення на знесення. Фізичний строк життя об'єкта нерухомості нормується шляхом встановлення щорічного амортизаційного внеску, що компенсує його відтворювальну вартість. Повна амортизація об'єкта означає лише нормований термін життя об'єкта нерухомості. Фактично об'єкт нерухомості при належному догляді та обслуговуванню може бути продовжений і дорівнювати економічному строку життя об'єкта нерухомості. На жаль, крім складової об'єкта нерухомості - земельної ділянки, невмолимий закон природи в кінці кінців призведе до повного зношення об'єкта нерухомості та його ліквідації.

Ефективний строк життя - це термін ринкового існування об'єкта нерухомості, основу його становить зовнішній вигляд та технічний стан. Це термін життя об'єкта нерухомості, при якому його зовнішній вигляд і технічний стан ще уможливлюють привабливість для потенційних покупців, тобто знаходиться на більш-менш задовільному рівні попиту. Це стан фактичного збереженого стану споживчої цінності об'єкта нерухомості на момент його представлення на ринок, не залежно від його хронологічного віку.

Хронологічний строк життя - цеперіод від дати введення об'єкта в експлуатацію до дати угоди.

Залишковий строк життя об'єкта промислової нерухомості - це строк, який відраховується від моменту оцінки його стану до закінчення терміну економічного життя. Він може бути продовжений завдяки відповідним діям власника: поліпшенню, капітальному ремонту, модернізації та реконструкції.

На початку досліджень ми вже говорили, що термін "життєвий цикл" запозичений аналітиками ринку з біологічної науки, як природа існування всього живого. Періоди життєвого циклу наперед визначені у своїй послідовності і неминучості. Тому деякі фахівці з маркетингу рекомендують досить обережно відноситись до використання на практиці такої моделі, хоча і не мають сумніву в іiі корисності [2]. Стосовно застосування терміну життєвого циклу до ринку об'єктів нерухомості, треба бути вдвічі обережнішим. Перше - це 
методологія визначення періодів, пов'язана 3 обсягом продаж, яка для об'єктів нерухомості повістю неприйнятна i вимагає спеціального дослідження основи експлікативних механізмів життєвого циклу, впливу усіх експлікативних змінних на формування життєвого циклу об'єктів нерухомості та їх тривалості. Об'єкти нерухомості - це специфічний товар, суто індивідуальний, унікальний та регіональний, пов'язаний 3 конкретного місцевістю і $з$ конкретним населеним пунктом, і мова йде про продаж цього конкретного об'єкта нерухомості, розташованого на конкретній земельній ділянці, в конкретному населеному пункті. Що ж до обсягу продажу аналогічних об'єктів, то мова може йти лише в статистичному плані, тобто в межах адміністративного органу звітності або в межах усієї країни. Друге - це абсолютна залежність життєвого циклу об'єкта нерухомості від поведінки та дій власника. Життєвий цикл об'єкта нерухомості повністю детермінований поведінкою його власника і всі фактори впливу змінні. А фактори, що незмінні та випливають 3 природної специфіки об'єктів нерухомості, як, наприклад, неможливість перенесення об'єкта нерухомості в інше місце, де існує незадоволений попит, не можуть бути реалізовані. Якщо підсумувати перше та друге, то можна зробити такий висновок, що традиційна форма життєвого циклу як залежності обсягу продаж від часу може застосуватись в основному до компаній виробників об'єкта нерухомості, тобто до виду товару, а не до самого товару. Справді компанії виробники об'єктів нерухомості, наприклад девелоперські компанії, які діють у різних регіонах країни при входженні на ринок промислової нерухомості, безумовно, проходять усі традиційні періоди зросту, стабілізації та спаду.

Відносно конкретного об'єкта нерухомості то його життєвий цикл може змінюватись і набувати найнеймовірніших форм залежно від дій власника. Може бути декілька періодів зросту та стабілізації у зв'язку з своєчасним переобладнанням або реконструкцією, може бути стабілізація без зросту, може бути відновлення зросту після занепаду (відбудова об'єкта в попередньому вигляді), може бути занепад зразу після росту i iн.

Типовий варіант фізичного життєвого циклу об'єктів нерухомості має п'ять періодів, а саме: розробка та створення, виведення на ринок, зріст попиту, період стабільного попиту, зменшення попиту.

Період створення. Інвесторам і власникам майбутніх об'єктів притаманні такі основні дії та їх послідовність: пошук ідеї створення об'єкта та iii оцінка; розробка концепції створення; розробка бізнес-плану створення; економічний аналіз, потреба в ресурсах; бізнес-план залучення інвестицій; створення відповідного органу управління процесом створення об'єкта нерухомості. Кожен із цих заходів спрямований на отримання необхідної інформації, аналізу та вироблення необхідних управлінських рішень. Це далеко не повний перелік першочергових дій, які повинні вчинити майбутні власники або інвестори, для прийняття рішення що до створення об'єкта промислової нерухомості. Подальшим процесом створення об'єкта буде управляти створений орган (відділ, підприємство) у відповідності до розроблених проектів та планів. Створення об'єкта нерухомості це досить капіталоємкий та довготривалий процес, з притаманним високим ступнем ризику. Протягом усього періоду він потребує постійної маркетингової та інформації, аналізу та тотального контролю за реалізацією створення споживчої цінності, яка б відповідала уявній цінності майбутніх споживачів.

Період виведення на ринок. Згідно 3 класичним визначенням, - це період, на якому новий товар, в нашому випадку новий об'єкт нерухомості, вперше надійшов на ринок, тобто вперше заявлений на продаж. Для об'єктів нерухомості процес виведення на ринок конкретного об'єкта повинен розпочатися на самому початку його створення. Коли з'являється ідея створення об'єкта нерухомості, для успішного його реалізації на ринку необхідно розпочати маркетингові дослідження не тільки ринку відповідного сектора нерухомості, а також місця та району розташування, (району збуту) прилеглої інфраструктури, соціального оточення і т.ін. Цей процес повинен проводитися постійно, до самого завершення проекту створення, та вноситись у проект необхідні корективи. Можуть бути запущені в дію різноманітні стратегії виведення захисту об'єкту нерухомості на ринок. Основне завдання, яке повинен виконати виробник, це якомога скоріше сформувати первинний попит. Це допоможе усунути фактор невизначеності, який зазвичай існує на самому початку процесу. Суть проблеми в тому, що виробник об'єкта нерухомості, наприклад девелоперська компанія, провела маркетингові дослідження, визначила цільове призначення та розробила проект створення об'єкта нерухомості. Більше того, вона навіть розробила ключові диференціатори, які відрізняють їі товар від інших аналогічних об'єктів нерухомості, що вже експлуатуються споживачами і в тій чи іншій формі задовольняють їх потреби, але вона не може знати задовольняє іï об'єкт нерухомості мета цінність, сформовану в уяві потенційного покупця на деякий період. Адже все швидко змінюється, і те, що в недавньому минулому було привабливе на сьогодні вже не $\epsilon$ таким. Тому отримати першу реакцію потенційних 
споживачів на створюваний об'єкт нерухомості дуже важливо. Чим раніше виробник об'єкта нерухомості отримає реакцію потенційних покупців, тим більше часу буде в нього для корегування проекту, щоб його споживча цінність відповідала вимогам потенційних споживачів. Для цього необхідно:

- домогтися широкого розголосу про створення об'єкта нерухомості;

- розповсюджувати інформацію про вигоди які несе створення об'єкт нерухомості;

- зацікавити потенційних покупців оглянути місце та познайомитися 3 проектом створення об'єкта нерухомості;

- ввести об'єкт нерухомості в реалізаційну мережу.

Надзвичайно важливим при запуску об'єкта нерухомості на промисловий ринок є визначення стратегії цінової політики. Особливо якщо створюємий об'єкт нерухомості багатоцільовий, тобто призначений для використання в різних цілях (виробництво, торгівля, офіси, розваги і т.п.) відповідними споживачами. Правильно вибрати зв'язок ціни проникнення на ринок 3 ціною максимізації майбутніх доходів - досить складна дилема, особливо в період запуску об'єкта нерухомості на ринок. Для виробника нерухомості ціна відіграє подвійну роль - 3 одного - це стимуляція попиту, з іншого боку головний фактор формування механізму повернення інвестицій та майбутньої рентабельності експлуатації об'єкта нерухомості. Раннє спілкування $з$ потенційними споживачами нерухомості дозволить визначити:

- Реакцію потенційних споживачів на визначені виробником ключові диференціатори, адже створення відмітностей, які, на думку виробника, мають у майбутньому позитивно впливати на прийняття рішення покупцем, потребують вкладення відповідних інвестицій. Економічно недоцільно вкладати кошти в поліпшення, які не будуть у майбутньому затребувані та не збільшуватимуть споживчу цінність об'єкта нерухомості.

- Реакцію ринку промислової нерухомості на ціну об'єкта нерухомості, яку хотів би отримати виробник. Ціни - це моніторинг вираження споживчої цінності об'єкту нерухомості. Для потенційного покупця нерухомості ціна об'єкта нерухомості - це розмір та природа задоволення, якого він очікує при здійсненні процесу придбання. Для промислового покупця ціну об'єкта нерухомості можна визначити, як співвідношенням кількості коштів витрачених на придбання до розміру прибутків отриманих від використання придбаного. Звичайно, це дещо спрощений погляд на ціну об'єкта нерухомості. Насправді ж на теренах обміну об'єкта нерухомості на деяку суму грошей є багато інших якісних факторів, які можуть впливати на їх рух у той чи інший бік. Проте цього погляду достатньо, щоб визначити реакцію ринку на запропоновану вартість нерухомості та напрямку іiі корегування. Отже, визначивши на ранній стадії створення об'єкта нерухомості та реакцію суб'єктів ринку промислової нерухомості на введення нового продукту, виробник може визначитися з доцільним обсягом інвестицій та терміном їх повернення та відповідно чином скорегувати напрямок реалізації проекту, а саме:

- виключити з проекту усі поліпшення, що не збільшують споживчу цінність об'єкта нерухомості;

- скоротити обсяг інвестицій;

- поліпшити об'єкт нерухомості, додаючи важливі властивості;

- установити привабливу ціну, що є на рівні ринкової та забезпечує необхідний термін повернення інвестицій.

Період зросту. Попередній період життєвого циклу нерухомості, як життєвого циклу ринку товару, відрізняється від аналогічного періоду життєвого циклу інших промислових товарів хіба що за обсягом проведення необхідних дій. Що ж стосується переліку напрямку та суттєвого наповнення, то вони аналогічні діям введення на ринок інших промислових товарів. Період зросту ринку товарів для об'єктів нерухомості має зовсім інші характеристики, пов'язані не зі збільшенням обсягу продажу, а скоріше зі збільшенням незадоволеного попиту на відповідні об'єкти нерухомості. Об'єкт нерухомості - це суто індивідуальний і навіть унікальний товар, попит на який цілком залежить від економічної ситуації в регіоні, конкретному населеному пункті і в країні в цілому. Наведемо такий приклад. Поліпшення економічної ситуації стало причиною збільшення виробництва обладнання, що потребує збільшення виробничих площ. Було прийнято рішення про придбання додаткового об'єкта нерухомості. У районі розміщення підприємства виробництва обладнання на регіональному ринку товарів об'єктів нерухомості, такого цільового і функціонального призначення не представлено. Тобто незадоволений попит. На інших регіональних ринках, можливо, є відповідна нерухомість, але це економічно невигідно для підприємства. Необхідно створити там інфраструктуру, транспортні витрати і т.ін. Але підприємство не залишає своїх намірів на розширення і починає вивчати можливість придбання представлених на ринку інших об'єктів нерухомості, 3 метою зміни ї цільового і функціонального призначення. Таким чином $\epsilon$ незадоволений попит і зростаючий попит. Вплив 
цього процесу на суб'єктів ринку - продавці мають можливість збільшувати назначені ціни, а покупці прискорити процес прийняття рішення. В цілому це призведе до активізації ринку і збільшення обсягу збуту, але не шляхом збільшення кількості проданого товару, а шляхом збільшення ціни та прискорення динаміки процесу.

Дії виробника, необхідні протягом цього періоду:

- розширити, наскільки це можливо, цільове та функціональне призначення об'єкта нерухомості;

- твердо підійти до сегментації цільового ринку товарів - об'єктів нерухомості та диференціації характеристик;

- оперативно керувати змінами у стратегії цінової політики;

- поліпшення системи управління нерухомістю, надання нових додаткових послуг, зниження затрат на експлуатацію.

Період стабілізації. Попит на об'єкти нерухомості надзвичайно тісно пов'язаний 3 економічною ситуацією. При стабільній економічній ситуації виробництво, комерційна діяльність знаходяться у стадії стабільного планового зростання, це сприяє росту доходів населення, підвищеного життєвого рівня, покупної спроможності і т.п. Тому споживачем виробничої та комерційної нерухомості уже немає нагальної необхідності збільшувати виробництво, а комерційному бізнесу - його розширення. Промислові підприємства та комерційні структури всі свої плани щодо розширення обсягу виробництва та комерційної діяльності вирішують за рахунок новітніх технологій заміни об'єктів нерухомості, придбаних раніше, на більш придатні для їх цільового використання, менш витратні в обслуговуванні і т.ін. Значний відсоток ринку об'єктів нерухомості в період стабілізації задіяний на чисто формальних операціях передачі об'єктів нерухомості від одного власника до іншого. Цей період стабілізації можна охарактеризувати так:

- ринок об'єктів нерухомості становить надзвичайно вузько сегментний, оскільки домінуючий попит - це попит на заміну менш придатних для конкретного цільового та функціонального призначення на більш придатні;

- на ринку об'єктів нерухомості домінуючими залишаються небагато виробників нерухомості, але досить потужних;

- у цілому попит практично стабільний на об'єкти нерухомості, зростання має місце в окремих видах, пов'язаних з економічним ростом окремої галузі, наприклад готельному бізнесі.

Основним завданням виробників нерухомості в цьому періоді це зберегти свою долю ринку та по можливості досягти стійкого положення на конкурентному полі. Для цього необхідно ще більш детально диференціювати характеристики об'єктів нерухомості; шукати ринкові пустоти в сегментах промислових ринків; удосконалювати управління об'єктами нерухомості; знижувати витрати на експлуатацію за рахунок введення нових технологічних процесів, модернізації обладнання, дотримання режимів економії. Період стабілізації - це період найвищої рентабельності, тому чим довше він у часі буде продовжений, тим більший прибуток отримують власники нерухомості. За період стабільності може змінитись декілька споживачів об'єкта нерухомості, об'єкт нерухомості може змінити або скорегувати цільове та функціональне призначення, може отримати поліпшення, об'єкт нерухомості може бути відремонтовано і навіть реконструйовано. Період стабілізації для об'єктів нерухомості може тривати десятки років, а в разі виконання в цьому періоді капітального ремонту або реконструкції навіть набагато більше. Узагалі цей термін не має економічного підгрунтя для обмеження в часі та практично повністю відповідає динаміці змін економічної ситуації в регіоні і в державі в цілому.

Період зниження (або падіння). Які причини можуть призвести до зниження і навіть падіння попиту на об'єкт нерухомості як товар промислового ринку:

- фізичний знос об'єкта нерухомості, це стосується як виробничих, так і комерційних об'єктів, тому період зниження попиту, як на неякісний товар, може розпочатись як по закінченні періоду стабілізації, так і на якомусь його етапі. Спонукати до цього може неякісне обслуговування та догляд об'єкта нерухомості, а також якість використаних при його створенні матеріалів;

- погіршення споживчої цінності у зв'язку 3 зміною технологічного процесу ведення виробництва або бізнесу, коли новітні технології неможливо впровадити в існуючих будівлях або спорудах;

- економічні, соціальні або економічні зміни в оточуючому середовищі роблять об'єкти нерухомості непридатними до використання за цільовим і функціональним призначенням;

- фінансовий стан власника об'єкта нерухомості не дозволяє провести капітальний ремонт або реконструкцію.

Висновки та перспективи подальших досліджень. У результаті проведених досліджень:

- набули свого подальшого розвитку теоретичні засади розробки такої товарної категорії об'єктів нерухомості як життєвий цикл та їх видові проявлення: економічні, фізичні, цільові та функціональні, технічні, правові, соціальні, психологічні. 
Струлєв О. О.

- проведено поглиблене дослідження та аналіз життєвого циклу ринку товару об'єкта нерухомості, визначено межі застосування цього поняття, методологію визначення періодів життєвого циклу, фактори впливу дій власника на динаміку змін характеру життєвого циклу.

- подальші дослідження життєвого циклу об'єктів промислової нерухомості доцільно спрямувати в напрямку дослідження об'єктів промислової нерухомості як фінансового активу; доцільно проаналізувати поняття фінансового життєвого циклу, що визначається як динаміка змін, які відбувається 3 об'єктом промислової нерухомості як фінансовим активом і пов'язана 3 еволюцією реального активу та змінами ринкового попиту; перше характеризується фізичними характеристиками (станом) об'єкта промислової нерухомості, а друге - глобальними змінами в економіці та іiі ринкових складових; аналізуючи фінансові потоки, що мають місце на різних етапах фінансового життєвого циклу, можна активно впливати на капіталізацію об'єктів промислової нерухомості та дохід, який вони генерують.

\section{Список літератури}

1. Основы маркетинга / Котлер Ф., Армстронг Г. - М. : Вильямс, - 2009, 1072 ст.

2. Ламбен Ж.-Ж. Стратегический маркетинг / Ж.-Ж. Ламбен. - Спб. : Наука, 1996. 583 ст.

3. Старостіна А.О., Длігач А.О., Кравченко В. А. Промисловий маркетинг: теорія, світовий досвід, українська практика. / Підручник за ред. А.О. Старостіної, К., Знания, 2005, 764 ст.

4. Гриценко Е.А. Ринок недвижимости: закономерности, становление, функционирование / Гриценко Е.А. Х., Бизнес-информ, 2002, 283ст.

5. Павлов В. І. Формування та становлення ринку комерційної нерухомості в регіоні. / Рівне, Вид. НУВТП, 2009, 128 ст.

6. Грибовський C. Оценка доходной недвижимости / Спб., Питер, 2000, 943 ст.

7. Кім М.М., Йоскина В.А., Роль ринку нерухомості в перехідній економіці, / Держ. інформ бюлет. про приватиз. 2001, №3, 54-58 ст.

8. Азарян А.А. Моніторінг ринку офісної нерухомості., / Азарян А.А., Донецьк, Вид "Вебер", 2008, 107 ст.

9. Горемыкин В.А. Экономика недвижимости / В.А.Горемыкин. - М. : Изд. "Дашков и К", 2005., 656 ст.

10.Харрисон Г.С. Оценка недвижимости / Г.С.Харрисон. - М. : РОО, 1994., 231 ст. 


\section{ЖИЗНЕННЫЙ ЦИКЛ ОБЬЕКТОВ ПРОМЫШЛЕННОЙ НЕДВИЖИМОСТИ КАК ТОВАРА ПРОМЫШЛЕННОГО РЫНКА}

Показано, что каждый рынок товаров, в том числе промышиленный, каждый сегмент рынка промышленных товаров, в том числе рынок промышленной недвижимости соответствует отдельному жизненному цүиклу. Жизненный цикл объектов недвижимости полностью определен поведением его собственника, и все факторы влияния являются переменными. A те факторы, которые являются постоянными и исходят из естественной специфики объектов недвижимости, как например невозможность переноса объекта недвижимости в другое место, где существует неудовлетворенный спрос, не могут быть реализованы. Резюмировано, что традиционная форма жизненного ияила как зависимость объема продаж от времени может применяться, в основном по отношению к компаниям, производителям объектов недвижимости, то есть квиду товара, а не к самому товару.

Ключевые слова: жизненный ичикл, объект недвижимости, товар, продажа, рентабельность.

\section{Summary}

Aleksandr Struliev

\section{LIFE CYCLE OF COMMERCIAL REAL ESTATE AS A PRODUCT OF INDUSTRIAL MARKET}

It is shown that each product market, inclusive industrial, each industrial product market segment correspond to a certain life cycle. The commercial real estate life cycle is fully determined by its owner behavior and all the influence factors are changeable. Those factors that are permanent and originate from the natural specific of the commercial real estate objects, like impossibility to move the real estate object to another location with unsatisfied demand cannot be realized. It is concluded that the traditional form of the life cycle as sales volume dependence on time can be applied mainly to the companies, producers of real estate objects, in other words to the type of a product, but not to the product itself.

Key words: life cycle, real estate object, product, sales, profitability. 
УДК 338.45:37

(C) Антохов А.А., Клевчік Л.Л., 2011

Чернівецький національний університет імені Юрія Федьковича, м. Чернівці

\section{АНАЛІЗ НАДАННЯ ТА СПОЖИВАННЯ ОСВІТНІХ ПОСЛУГ ВИЩОЇ ОСВІТИ В ЧЕРНІВЕЦЬКІЙ ОБЛАСТІ}

Проведено оиінку основних показників надання та отримання освітніх послуг у ВНЗ; досліджено динаміку споживання послуги вищої освіти в Чернівецькій області; охарактеризовано зміни, які вносить у функціонування українського ринку освітніх послуг Болонський проиес, його переваги та недоліки; проаналізовано якісну характеристику споживачів освітніх послуг, їх територіальну диференціацію та належне кадрове забезпечення.

Ключові слова: вища освіта, вищі навчальні заклади, споживачі освітніх послуг, надавачі освітніх послуг, ринок осітніх послуг, Болонський процес.

Освітні послуги як обсяги навчальної та наукової інформації, яка трансформується у процесі навчання в певну суму знань для задоволення потреб фізичних та юридичних осіб у дошкільній, загальноосвітній, професійнокваліфікаційній підготовці, перепідготовці, навчанні впродовж всього життя, є центральним (найголовнішим) елементом ринку освітніх послуг, що функціонує на міжнародному, національному й регіональному рівнях.

У нинішній системі надавачів освітніх послуг особливе місце займає система зовнішнього незалежного оцінювання. Вона від імені держави здійснює оцінку випускників школи, ліцеїв, ПТНЗ щодо рівня їхніх знань та видає відповідні сертифікати, що $є$ документом, який відкриває можливість отримати вищу освіту у BH3 III-IV рівня акредитації. Реалізація потреби у вищій освіті здійснюється у процесі споживання послуг ВНЗ відповідного рівня акредитації. Суб'єктами цього сегменту ринку освітніх послуг виступають студенти, їхні батьки, юридичні особи, що фінансують підготовку спеціалістів для власних потреб, органи місцевого самоврядування та влада в регіонах, держава. Опосередковано цю послугу споживають працедавці, які отримують можливість найму молодих спеціалістів [1].

Споживання освітніх послуг у ВН3 дає можливість отримати певний фах як основу майбутньої економічної свободи вибору місця професійної діяльності, як основу певного соціального статусу та можливості для професійного та службового просування. У процесі споживання освітньої послуги ВНЗ дають оцінку майбутнім спеціалістам і на основі цісї оцінки здійснюють відбір кращих студентів

Згідно з чинним законодавством, освітні послуги вищої освіти надають технікуми, училища, коледжі, інститути, консерваторії, академії, університети тощо. За статусом вищих навчальних закладів (ВН3) встановлено чотири рівні акредитації: I - технікуми, училища; II коледжі та інші прирівняні до них заклади; III і IV - академії, університети, інститути, консерваторії. У системі вищої освіти освітня послуга надається за освітньо-кваліфікаційними рівнями: молодший спеціаліст (надають технікуми, училища, інші вищі навчальні заклади I рівня акредитації); бакалавр (надають коледжі, інші вищі навчальні заклади IIIV рівнів акредитації); спеціаліст, магістр (надають вищі навчальні заклади III і IV рівнів акредитації) [3].

На початок 2009/10 н.р. в Чернівецькій області на освітньому ринку надавали освітні послуги вищої освіти 17 ВНЗ I-IV рівнів акредитації. Реальними споживачами послуг ВНЗ I-II рівнів стали 27864 осіб та 6125 осіб у ВН3 III-IV рівнів акредитації [4, с.6].

Особливості надання освітніх послуг у ВНЗ I$\mathrm{V}$ рівнів у динаміці демонструють дані табл.1 та табл. 2. У ВНЗ І-ІІ рівнів акредитації здобувають вищу професійну освіту, готують фахівців середньої ланки, підвищують освітній і культурний рівень особистості. Об'єктивні причини, зокрема порушення традиційних зв'язків навчальних закладів із замовниками кадрів і недостатня взаємодія органів управління освітою 3 територіальними службами зайнятості населення, вимагають зміст і структуру освіти привести у відповідність із потребами економіки й соціальної сфери регіонів, потребують удосконалити організацію практичної підготовки студентів та підвищити рівень працевлаштування випускників.

Для подолання зазначених диспропорцій у цьому сегменті регіонального ринку необхідно здійснити оптимізацію постачальників освітніх послуг (BН3 I-ІІ рівнів акредитації) з урахуванням економічної ситуації, потреб регіонів у кадрах, матеріально-технічного та кадрового забезпечення ВНЗ. Напрямами оптимізації 
мають бути: укрупнення ВНЗ для уникнення дублювання спеціальностей i скорочення бюджетних витрат на їх утримання; створення на їх базі багатопрофільних і багаторівневих вищих навчальних закладів.

Основні показники надання й отримання освітніх послуг у ВНЗ І-II рівнів

Таблиия 1 Чернівецької області (на початок навчального року) [2, с.4; 5, с.13; 4, с.6].

\begin{tabular}{|c|c|c|c|c|c|c|c|c|c|c|}
\hline & $\begin{array}{c}1990 / \\
91\end{array}$ & $\begin{array}{l}1995 / \\
96\end{array}$ & $\begin{array}{c}2000 / \\
01\end{array}$ & $\begin{array}{c}2002 / \\
03\end{array}$ & $\begin{array}{c}2003 / \\
04\end{array}$ & $\begin{array}{c}2004 / \\
05\end{array}$ & $\begin{array}{c}2005 / \\
06\end{array}$ & $\begin{array}{c}2006 / \\
07\end{array}$ & $\begin{array}{c}2007 / \\
08\end{array}$ & $\begin{array}{c}2008 \mid 0 \\
9\end{array}$ \\
\hline Кількість закладів & 18 & 18 & 16 & 15 & 17 & 16 & 16 & 15 & 13 & 13 \\
\hline $\begin{array}{l}\text { В них студентів, } \\
\text { тис. }\end{array}$ & 14,2 & 12,5 & 13,6 & 13,1 & 14,1 & 13,4 & 13,6 & 12,7 & 10,96 & 10,04 \\
\hline Прийнято, тис. & 4,5 & 3,9 & 4,6 & 4,4 & 4,6 & 4,3 & 4,4 & 4,1 & 3,544 & 2,7 \\
\hline Випущено, тис. & 4,2 & 3,7 & 3,6 & 3,7 & 4,0 & 3,9 & 3,8 & 3,7 & 3,354 & 3,086 \\
\hline $\begin{array}{l}\text { Кількість студенті } \\
\text { на } 10 \text { тис. } \\
\text { населення } \\
\text { Чернівецька обл. }\end{array}$ & & & 146 & 142 & 153 & 147 & 150 & 140 & 121 & 111 \\
\hline Україна & 146 & 120 & 107 & 121 & 125 & 116 & 108 & 100 & 95 & 87 \\
\hline
\end{tabular}

Таблиця 2

Основні показники надання та отримання освітніх послуг у ВН3 III-IV рівнів Чернівецької області (на початок навчального року) [2, с.5; 4, с.6; 5, с.13].

\begin{tabular}{|c|c|c|c|c|c|c|c|c|c|c|}
\hline & $\begin{array}{c}1990 \\
/ 91\end{array}$ & $\begin{array}{c}1995 / \\
96\end{array}$ & $\begin{array}{c}2000 / \\
01\end{array}$ & $\begin{array}{c}2002 / \\
03\end{array}$ & $\begin{array}{c}2003 \\
04\end{array}$ & $\begin{array}{c}2004 / \\
05\end{array}$ & $\begin{array}{c}2005 / \\
06\end{array}$ & $\begin{array}{c}2006 \\
07\end{array}$ & $\begin{array}{c}2007 / \\
08\end{array}$ & $\begin{array}{c}2008 / \\
09\end{array}$ \\
\hline Кількість закладів & 2 & 2 & 4 & 5 & 5 & 4 & 4 & 4 & 4 & 4 \\
\hline В них студентів, тис. & 11,9 & 12,6 & 17,6 & 21,6 & 25,6 & 24,3 & 25,8 & 26,9 & 27,48 & 27,86 \\
\hline Прийнято, тис. & 2,4 & 2,5 & 4,3 & 7,2 & 6,5 & 5,7 & 6,6 & 5,9 & 6,125 & 5,774 \\
\hline Випущено, тис. & 1,8 & 2,1 & 3,4 & 3,9 & 4,3 & 3,8 & 4,6 & 4,4 & 4,724 & 6,189 \\
\hline $\begin{array}{l}\text { Кількість студентів на } \\
10 \text { тис. населення: } \\
\text { Чернівецька обл. }\end{array}$ & $\ldots$ & $\ldots$ & 179 & 258 & 279 & 267 & 284 & 297 & 303 & 295 \\
\hline Україна & 170 & 180 & 285 & 352 & 387 & 429 & 470 & 497 & 511 & 512 \\
\hline
\end{tabular}

Якщо у секторі ВНЗ І-ІІ рівнів акредитації Буковини показник кількості студентів на 10 тис. населення в усі роки був значно вищим, ніж в середньому по Україні, то у ВНЗ III-IV рівнів акредитації рівень аналогічного показника $\epsilon$ суттєво нижчим від загальноукраїнського.

За досліджуваний період мережа BHЗ III-IV рівнів акредитації зросла у 2 рази, кількість споживачів послуг - у 2,3 рази. Це забезпечило зростання кількості студентів на 10 тис. населення: від 179 студентів у 2000/01 н.р. до 303 студентів у 2008/09 н.р., в Україні, відповідно, - 3 170 до 512 студентів.

Наведемо якісну характеристику споживачів освітніх послуг Чернівецької області за такими критеріями: територіальна ознака, форми власності, вікові групи, окремі категорії студентів, галузі знань, форма навчання, мова навчання, кадрове забезпечення (табл.3) [2, с. $11 ; 12 ; 13$; $15 ; 18 ; 20]$.

У структурі освітніх послуг $81,3 \%$ надається мережею ВНЗ I-II рівнів акредитації, які розміщені у м. Чернівці. Решту сегмента цих послуг надають ВН3, які розташовані у Вижницькому, Новоселицькому та Сторожинецькому районах області. Натомість споживачі освітніх послуг ВНЗ III-IV рівнів акредитації на $100 \%$ отримують їх тільки у м. Чернівці. ВНЗ державної та комунальної форм власності III-IV рівнів акредитації пропонують більше освітніх послуг, ніж 


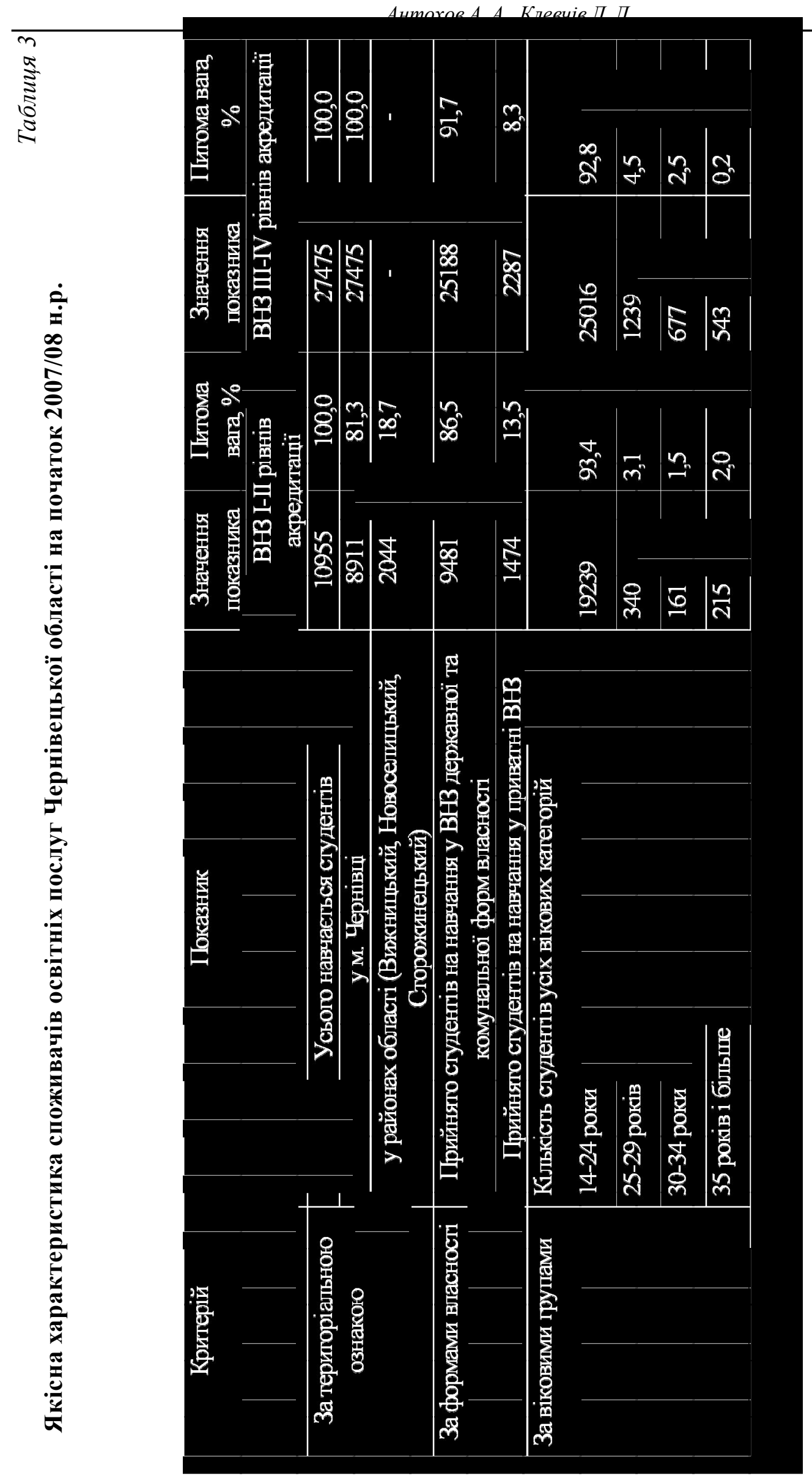




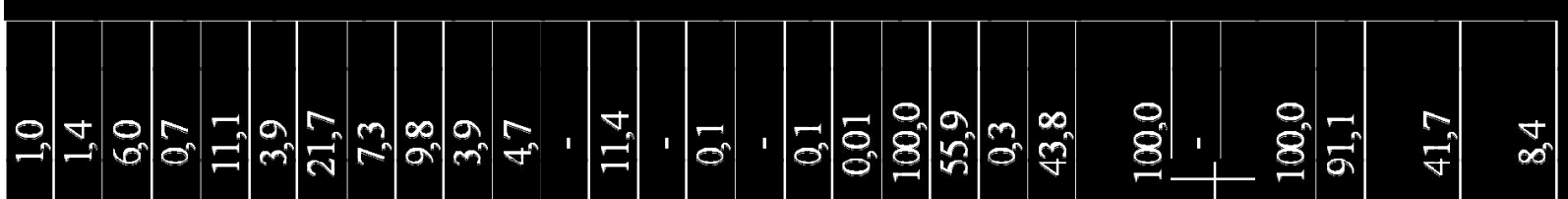
采

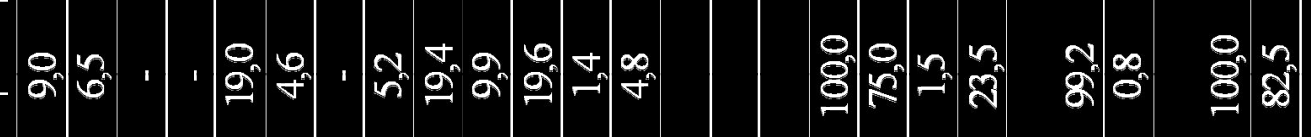

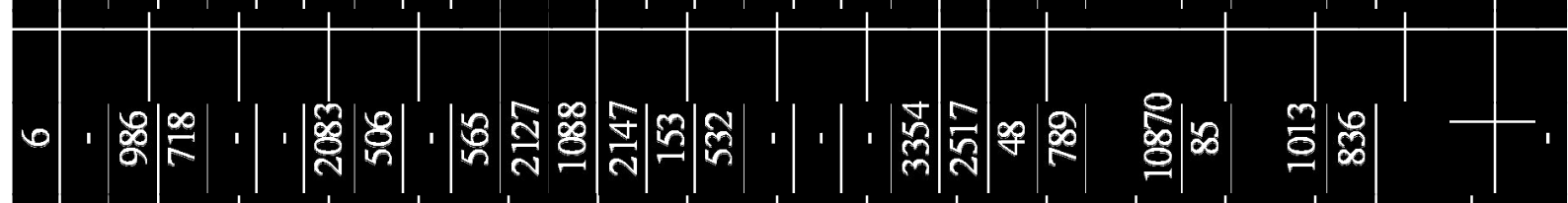

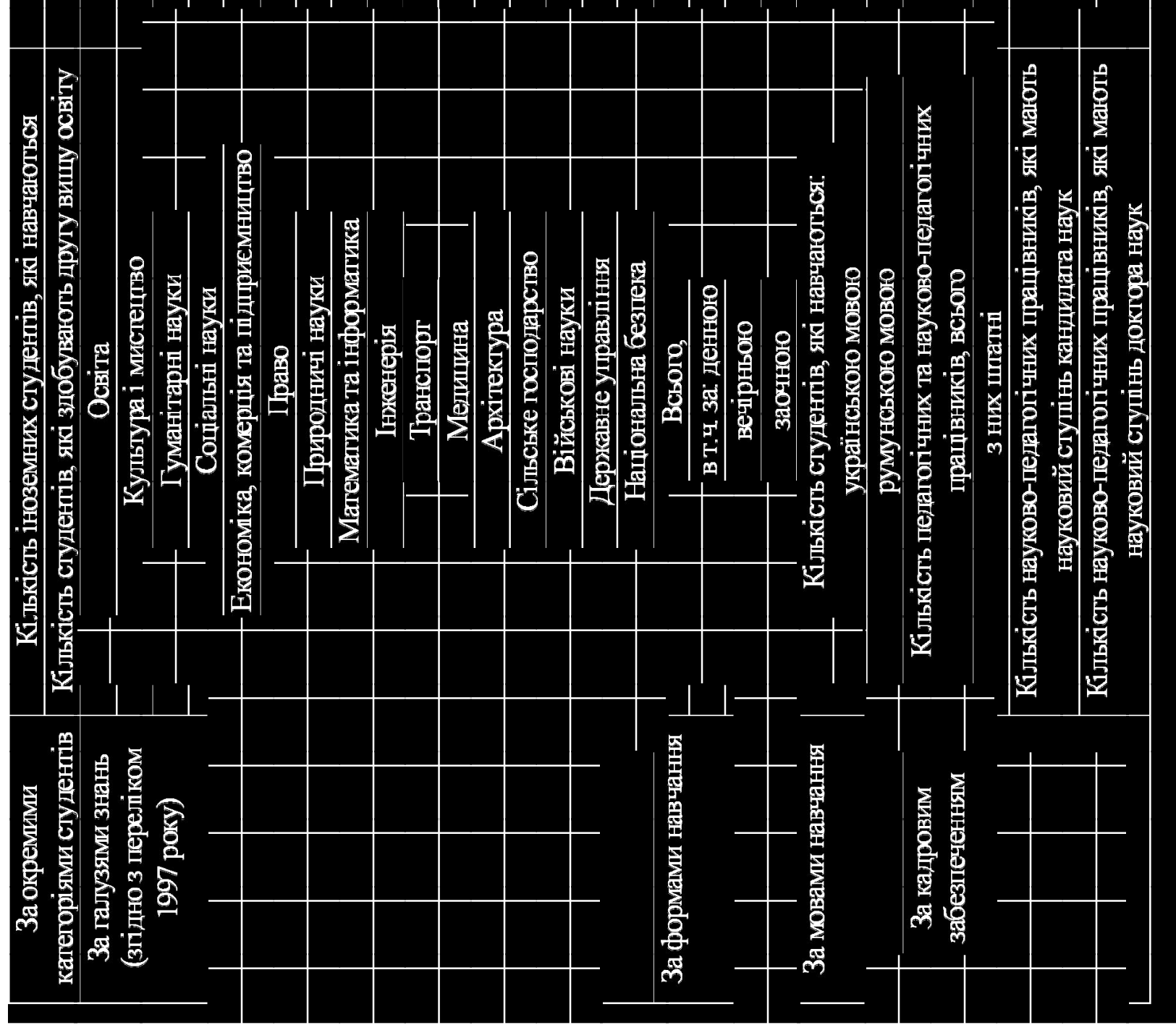


Антохов А. А., Клевчів Л. Л.

BН3 I-II рівнів: 91,7\% проти 86,5\%.

За віковою структурою споживачі освітніх послуг, які надаються ВНЗ I-II рівнів та ВН3 IIIIV рівнів, розподілені так. Частка вікової групи 1424 роки є приблизно однаковою - відповідно 93,4\% та 92,8\%. Переважання перших пояснюється доступом до навчання учнів після закінчення 9го класу. У віковій групі 25-29 років переважає частка споживачів освітніх послуг у ВН3 III-IV рівнів - 4,5\% проти 3,2\% . Така ж тенденція у віковій групі 30-34 роки - відповідно 2,5\% проти $1,5 \%$. Отримане співвідношення споживачів освітніх послуг пояснюється прагненням населення 25-29 років та 30-34 років отримати другу вищу освіту, підвищити професійний рівень тощо. Натомість вікова категорія 35 років і більше переважає у ВНЗ I-II рівнів (2,0\% проти $0,2 \%)$, оскільки останні більш активно включені у процеси навчання, підвищення кваліфікації через службу зайнятості Чернівецької області.

За окремими категоріями студентів лише ВНЗ III-IV рівнів надають освітні послуги іноземним студента (1,0\%) та особам, які здобувають другу вищу освіту (1,4\%). В умовах входження України у Болонський процес, інтеграції у загальноєвропейський освітній простір, безумовно, цей сегмент надання освітніх послуг має суттєво зрости.

Найбільша в області частка одержувачів освітніх послуг, які закінчили ВНЗ, спостерігається за денною формою навчання, проте відповідний показник у підсистемі ВНЗ I-II рівнів акредитації є суттєво більшим, ніж у ВН3 III-IV рівнів - 75\% та $55,9 \%$. За мовним критерієм $100 \%$ студентів отримують освітні послуги українською мовою у BH3 III-IV рівнів акредитації. ВН3 I-II рівнів викладання українською мовою $(99,2 \%)$ поєднується 3 навчанням румунською мовою $(0,8 \%)$. За рівнем кадрового забезпечення як важливого індикатора якості надання освітніх послуг державна статистика констатує наявність штатних педагогічних та науково-педагогічних працівників - 82,5\% від загальної кількості у ВН3 I-II рівнів та 91,1\% у ВН3 III-IV рівнів. Відзначається високий рівень науково-освітнього забезпечення навчання у ВН3 III-IV рівнів: 41,7\% науково-педагогічних працівників, які мають науковий ступінь кандидата наук та 8,4\% науковопедагогічних працівників, які мають науковий ступінь доктора наук.

Аналіз надання освітніх послуг за галузями знань показує, що вища освіта Буковини найбільшій мірі представлена напрямком "Економіка, комерція та підприємництво" відповідно 19,0\% та 21,7\% .у ВНЗ I-II рівнів та BH3 III-IV рівнів акредитації. Далі йде підготовка за напрямками медицини та інженерних наук
(19,6\% та 19,4\%), освітні послуги 3 яких надаються переважно у ВНЗ I-II рівнів акредитації. У ВН3 III-IV рівнів значних обсягів набула підготовка 3 медичних, гуманітарних та правознавчих наук - відповідно 11,4\%, 11,0\% та 7,3\%. Передумовами такого розподілу споживачів освітніх послуг за галузями знань $\epsilon$ трансформаційні зміни у структурі господарського комплексу регіону за роки державної незалежності. Припинення існування командноадміністративної системи економіки Буковини та, як наслідок, зникнення державних замовлень суттєво вплинуло на економіку області. Скоротились обсяги виробництва майже в усіх галузях, що позначилось на зростанні рівня безробіття, інтенсифікувало відтік висококваліфікованих кадрів. Зникли найважливіші для Чернівецької області галузі оборонного комплексу та скоротилось у декілька разів виробництво сільськогосподарської продукції. Виробництво у структурі економіки замінила торгівля [6, с. 5].

Для подолання депресивних змін, з метою поліпшення якості життя жителів області та поновлення їі економічного потенціалу розроблена Стратегію розвитку Чернівецької області до 2015 року та програму дій обласної державної адміністрації згідно з визначеними пріоритетами. На часі прийняття законопроекту "Про спеціальний режим інвестиційної діяльності на територіях пріоритетного розвитку в Чернівецькій області", який розроблено Чернівецькою ОДА. Його мета - створення нових робочих місць та поліпшення інвестиційного клімату в пріоритетних сферах економіки регіону (рекреація, транзит, використання природних ресурсів), зростання економіки в районах області, які є "депресивними". Зазначені документи та відповідні управлінські рішення обласної державної адміністрації $\epsilon$ важливим інституційним підгрунтям реалізації Стратегії розвитку Чернівецької області на період до 2015 року, яка вимагає, щоб структура споживачів освітніх послуг за галузями знань максимально відповідала стратегічним пріоритетам їі реалізації.

Отже, аналіз сучасного стану регіонального ринку освітніх послуг вищої освіти, які надаються фізичним та юридичним особам на різних рівнях освіти, показав їх територіальну диференціацію, зростаючі обсяги їх надання та багатоманітність, належне кадрове забезпечення. Інтереси соціально-економічного розвитку Буковини вимагають, щоб обсяги та спектр освітніх послуг за галузями знань максимально відповідали поточним i перспективним потребам регіонального ринку праці, стратегічним пріоритетам розвитку області на період до 2015 року. 


\section{Список літератури}

1. Вакарчук I. Університетська автономія і реформа вищої освіти. Ситуація в Україні: Доповідь на міжнародній конференції "Еліти, публічний діалог і реформа вищої освіти",8 грудня 2008 року, Варшава. - [Електронний ресурс]. Режим доступу: http://mon.gov.ua

2. Вищі навчальні заклади на початок $2007 / 08$ навчального року: Статистичний бюлетень./ Головне управління статистики у Чернівецькій області. -Чернівці, 2007. - 32 с.

3. Економіка знань - модернізаційний проект України / За ред.. акад. НАН України В.М. Гейця, акад.. НАН України В.П. Семиноженка, чл.- кор. НАН України Б.С. Кваснюка. - К.: Фенікс, 2007. - 544 c.

4. Заклади освіти на Буковині станом на 1 червня 2010 року: Статистичний бюлетень / Головне управління статистики у Чернівецькій області. - Чернівці, 2010. - 88 с.

5. Основні показники діяльності вищих навчальних закладів України на початок 2008/09 навчального року: Статистичний бюлетень / Державний комітет статистики України. - К., 2009. $-213 \mathrm{c}$.

6. 6. ТПР як механізм розвитку Буковини. - [Електронний ресурс]. - Режим доступу: http://

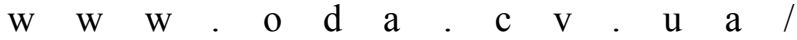
index.php?option=com_content\&task= view\&id=611\&Itemid $=59$

\section{АНАЛИЗ НАДАНИЯ И ПОТРЕБЛЕНИЯ ОБРАЗОВАТЕЛЬНЫХ УСЛУГ ВЫСШЕГО ОБРАЗОВАНИЯ В ЧЕРНОВИЦКОЙ ОБЛАСТИ}

Проведено анализ основных показателей надания и получения образовательных услуг в ВУЗ; проанализировано динамику потребления услуг высшего образования в Черновиикой области; охарактеризовано перемены какие вносит Болонский процес в функиионирование украинского рынка образовательных услуг; проанализировано качественную характеристику потребителей образовательных услуг, их территориальную дифференциачию и надлежащее кадровое обеспечение.

Ключевые слова: высшее образование, вузы, потребители образовательных услуг, поставщики образовательных услуг, рынок Оситная услуг, Болонский процес.

Summary

Andrey Antokhov, Leonid Klevchik

\section{ANALYSIS OF PROVIDING AND CONSUMPTION OF HIGHER EDUCATION SERVICES IN THE CHERNIVTSI REGION}

The estimation of basic parameters of providing and receiving educational services in higher education establishments; dynamics and consumption of higher education in the Chernivtsi region; the characteristic of changes which are introduced into the Ukrainian market of educational services through the Bologna process were researched in the article; analysis of qualitative characteristics of consumers of educational services and their territorial differentiation and proper staffing.

Keywords: higher education, universities, consumers of educational services, providers of educational services market ositnih services, Bologna. 


\section{ПІДПРИСМСТВО І ПІДПРИСМНИЦТВО}

УДК 338.45

(C) Карюк В. I., 2011

Київський національний університет імені Тараса Шевченка, м.Київ

\section{ОРГАНІЗАЦІЙНО-ЕКОНОМІЧНИЙ МЕХАНІЗМ АКТИВІЗАЦІЇ ІННОВАЦІЙНОЇ ДІЯЛЬНОСТІ ПІДПРИЄМСТВ}

У статті досліджено поняття і механізм здійснення інноваційної діяльності, ї̈ роль у розвитку економіки держави, проаналізовано основні тендениії інноваційного розвитку промислових підприємств в Украйні. Удосконалено систему показників для оцінки інноваційного розвитку підприємств. Виявлені основні проблеми, щз перешкоджають ефективному розвитку інноваційної діяльності вітчизняних підприємств на сучасному етапі, та визначено основні шляхи активізації інноваційної діяльності.

Ключові слова: інноваційна діяльність, інноваційний потенціал, організаційно-економічний механізм, промислове виробництво, ефективність.

Вступ. За умов посилення міжнародної конкурентної боротьби та сучасних тенденцій розвитку світової економіки, Україна все частіше використовує екстенсивні методи досягнення конкурентних переваг для подолання кризи. Це пояснюється тим, що екстенсивне зростання, тобто зростання за рахунок залучення в економічний оборот додаткових ресурсів, у певних ситуаціях може забезпечити більш швидкий ефект, ніж інтенсивне зростання.

Однак кількість незадіяних ресурсів вичерпна, тому основним джерелом зростання української економіки у довгостроковій перспективі може бути винятково підвищення ефективності виробництва за рахунок інноваційної складової, що значною мірою залежить від розвитку інноваційної діяльності і використання ефективних ринкових механізмів управління.

Низький технічний і організаційний рівень виробництва, недостатнє фінансування інноваційної діяльності не дають можливості сьогодні повною мірою розвиватися йому на інноваційній основі.

Тому одним 3 найбільш ефективних напрямків забезпечення ефективності промислового виробництва $\epsilon$ пошук таких умов його функціонування, які сприяли б розвитку інноваційної діяльності, спрямованої на розробку і використання результатів наукових досліджень, що дають можливість здійснити реструктуризацію, відновлення основних виробничих фондів, удосконалювати технологію, організацію й управління виробництвом.

Активізація інноваційної діяльності, як свідчить досвід промислово розвинених країн, $\epsilon$ визначальним напрямком забезпечення впровадження результатів науково-технічного прогресу у виробництво, підвищуючи його конкурентноздатність і стале становище на ринку товарів і послуг.

У цих умовах актуальне розв'язання проблем створення організаційно-економічних механізмів забезпечення ефективної діяльності промислових підприємств, управління підприємством взагалі та його розвитком, що забезпечує динамічне зростання економіки. Процес реалізації такого підходу вимагає ефективного використання потенціалу підприємства, що дає можливість оцінки наявних ресурсів для впровадження інновацій як фактора, який забезпечує розвиток підприємства і адаптацію до особливостей діяльності в макросередовищі.

Значний внесок у цьому напрямі досліджень вітчизняних учених: О.I. Амоші, О.М. Алимова, Я.Г. Берсуцького, Г.К. Губерної, В.М. Гейця, В.Г. Герасимчука, В.М. Гриньової, С.М. Ілляшенка, 
М.О. Кизима, Ю.В. Макогона, М.Д. Прокопенка, С.К. Рамазанова, В.А. Ткаченка, Р.Б. Тяна, М.Г. Чумаченка, Л.Г.Червової та зарубіжних - Г.Л. Багієва, В.А. Винокурова, О.С. Віханського, Е.М. Короткова, В. Г. Крижанівського.

Постановка проблеми. Втілення в життя інноваційної моделі розвитку економіки вимагає дослідження різноманітних об'єктів та явищ як системи, або складного і багатопланового механізму, що не обмежується відтворенням змін лише у науці, техніці, технології, а об'єднує інвестиційну, фінансово-грошово-кредитну політику, удосконалення організації праці та виробництва. Усі перелічені фактори функціонують у межах певного організаційноекономічного механізму, тісно взаємопов'язані та мають однакову цільову спрямованість.

Метою такого механізму є формування таких умов, що здатні забезпечити функціонування промислового виробництва в взаємодії 3 економічним, технологічним і соціальним середовищем. В результаті такої взаємодії і відбувається узгодження інтересів підсистем управління. Дієвість такого механізму визначається сукупним результатом функціонування його складових.

Сучасний стан техніко-технологічного потенціалу в Україні та його недостатнє використання для інноваційної діяльності не забезпечують передумов для підвищення ефективності виробничої діяльності підприємств.

У рейтингу конкурентної економіки Всесвітнього економічного форуму Україна за 2007-2008 роки посіла лише 73-тє місце проти 69го місця у цьому ж рейтингу за 2006-2007 роки. До десятки лідерів увійшли: США - 1 місце, далі: Швейцарія, Данія, Швеція, Німеччина, Фінляндія, Сінгапур, Японія, Велика Британія, Нідерланди. Аналіз економічного розвитку країн-лідерів показав, що можливість їхього входження в першу десятку забезпечило їм своєчасне залучення в економіку саме інноваційного чинника [1].

Тому за сучасних умов вітчизняного промислового виробництва, коли 3 одного боку існує значний науково-технічний потенціал, не використовуються повною мірою наявні виробничі потужності, трудові ресурси, а з іншого боку низький рівень організаційно-технічного розвитку виробництва, відсутність розвиненої інфраструктури інноваційної сфери, фінансових ресурсів та ін., гостро стає питання удосконалювання організаційно-економічного механізму для поліпшення економікотехнологічного розвитку промисловості.

Результати. Організаційно-економічний механізм інноваційного процесу можна визначити як взаємопов'язану сукупність економічних відносин, принципів, методів і форм організації створення, промислового впровадження та комерціалізації нововведень.

Основними групами елементів організаційноекономічного механізму інноваційного процесу є: економічні, науково-технічні, організаційні й інфраструктурні важелі взаємозалежні, причому, чим більше вони взаємопов'язані, тим більшою $\epsilon$ вірогідність одержання оптимальних результатів з точки зору обсягів і якості інноваційної продукції.

Системний характер даного поняття означає, що технологічний розвиток розглядається не у вигляді ланцюга односторонніх спрямованих лінійних причинно-наслідкових взаємозв'язків від НДДКР до інновацій, а як процес взаємодії та зворотних зв'язків між усім комплексом економічних, соціальних, політичних, організаційних та інших факторів, що визначають створення інновацій. [4, с.93]

У нашій державі рівень упровадження результатів НДДКР надзвичайно низький. Наслідком цього стало зменшення кількості інноваційно активних підприємств, гальмування розвитку високотехнологічних галузей промисловості та зниження рівня конкурентоспроможності економіки України.

Так, за оцінками Economist Intelligence Unit, за показником інноваційної динаміки в 2003-2007 pp. Україна 3-поміж 82 країн посідала 51 місце і 59 за показником дієвості чинників, що сприяють інноваціям [6].

Сучасний стан інноваційної діяльності в Україні характеризується наступними тенденціями:

1. Низьким рівнем інноваційної активності промислових підприємств. Частка підприємств, що займалися інноваційною діяльністю, в Україні суттєво менша, аніж у країнах, для яких інноваційний розвиток економіки $є$ пріоритетним завданням економічної стратегії. Так, якщо в ЄС таких підприємств у 2007 р. налічувалося 41,5\%, то в Україні інноваціями займалося лише 13,0 \% від загальної кількості промислових підприємств. (Табл. 1)

2. Неефективністю структури реалізованої інноваційної продукції. Динаміка галузевої структури реалізованої інноваційної продукції свідчить про переважне відтворення існуючої структури промислового виробництва. Проте для інноваційного розвитку вітчизняної промисловості цього явно недостатньо, оскільки майже дві третини інноваційної продукції в економіці України створюють виробництва третього і четвертого технологічних укладів. У 2008 році найбільша частка інноваційної продукції у загальному обсязі реалізованої промислової продукції припадала на галузь машинобудування - 17,8 млрд грн, що 


\section{Динаміка основних показників інноваційної діяльності промислових підприсмств в Україні за 2000-2008 рр.}

\begin{tabular}{|c|c|c|c|c|c|c|c|c|c|c|}
\hline № & Назва показника & 2000 & 2001 & 2002 & 2003 & 2004 & 2005 & 2006 & 2007 & 2008 \\
\hline & $\begin{array}{l}\text { Кількість підприємств, які } \\
\text { впроваджували інновації }\end{array}$ & 1491 & 1503 & 1506 & 1120 & 958 & 810 & 999 & 1186 & 1160 \\
\hline & \% до попереднього року & $\mathrm{x}$ & 100,8 & 100,1 & 74,3 & 77,4 & 84,5 & 123,3 & 118,7 & 97,8 \\
\hline & $\begin{array}{l}\text { Освоєно виробництво } \\
\text { нових видів продукції, } \\
\text { найменувань }\end{array}$ & 15323 & 19484 & 22847 & 7416 & 3978 & 3152 & 2408 & 1978 & 2446 \\
\hline & \% до попереднього року & $\mathrm{x}$ & 127,2 & 117,3 & 32,5 & 53,6 & 79,2 & 76,4 & 82,1 & 123,7 \\
\hline \multirow[t]{2}{*}{3.} & $\begin{array}{l}\text { Впроваджено нових } \\
\text { технологічних процесів }\end{array}$ & 1403 & 1421 & 1142 & 1482 & 1727 & 1808 & 1145 & 1024 & 1647 \\
\hline & \% до попереднього року & $\mathrm{x}$ & 101,3 & 80,4 & 129,8 & 116,5 & 104,7 & 63,3 & 89,4 & 160,8 \\
\hline \multirow[t]{2}{*}{4.} & $\begin{array}{l}3 \text { них маловідходних, } \\
\text { ресурсозберігаючих }\end{array}$ & 172 & 160 & 151 & 230 & 224 & 208 & 161 & 287 & 680 \\
\hline & \% до попереднього року & $\mathrm{x}$ & 93,0 & 94,4 & 152,3 & 97,4 & 92,9 & 77,4 & 178,3 & 236,9 \\
\hline
\end{tabular}

Джерело: Статистичний щорічник України за 2001, 2004 та 2007 роки та [5, с. 3]

складає 16,8 \% від загального обсягу реалізованої промислової продукції, целюлозно-паперове виробництво та видавничу діяльність - $10,9 \%$, або 15,1 млрд. грн, металургійне виробництво та виробництво готових металевих виробів - $18,4 \%$, або 16,3 млрд. грн, виробництво харчових продуктів, напоїв та тютюнових виробів - 5,3 \%, або 4515,9 млн грн. [2, с. 2].

3. Звуженням інноваційного потенціалу інвестицій. Активізація інноваційних процесів в Україні не супроводжується відповідним зростанням витрат на інноваційну діяльність. При цьому динаміка зростання інноваційних витрат за період 2001-2008 рр. практично не відрізняється від динаміки зростання інвестицій у промисловість. Протягом зазначеного періоду середньорічні темпи приросту інвестицій складали $20,2 \%$, тоді як приріст фінансування інноваційної діяльності становив $27,1 \%$. (Табл. 2)

4. Недосконалість структури інноваційних витрат. В Україні зростає орієнтація промислових підприємств на придбання готових технологічних рішень, при цьому знижується зацікавленість до самостійної розробки нових товарів і технологій: за останні роки частка витрат на дослідження і розробки порівняно з 2005-2006 р. зменшилася майже вдвічі [3, с.326].

5. Невідповідністю структури фінансування інвестиційної діяльності пріоритетам інноваційного розвитку економіки. У промисловості України більша частина інвестицій в основний капітал надходить у галузі, які за класифікацією ОЕСР належать до середньо-низькотехнологічних виробництво харчових продуктів, металургійне виробництво, виробництво неметалевої мінеральної продукції. Так, в Україні найбільший обсяг інноваційних витрат у 2008 році припадає на підприємства металургійного виробництва та виробництва готових металевих виробів - 2,8 млрд грн., на виробництво харчових продуктів, напоїв та тютюнових виробів припадає 1,7 млрд грн. Натомість у галузі, які забезпечують пропорційно більшу частку виробництва інноваційної продукції, залучено значно менші обсяги інвестицій. Інвестиційний процес в Україні не виконує інноваційну функцію, кінцевим результатом реалізації якої мала б стати структурна перебудова національної економіки.

Для узагальнення динаміки інноваційного розвитку нами були запропоновані та розраховані відносні показники, що найбільш глибоко ілюструють стан інноваційної сфери в Україні. Результати розрахунків згруповано в таблицю.(Табл. 3)

Як видно з таблиці, для України характерна спадна динаміка практично для всіх показників, що відображають рівень інноваційного розвитку промисловості країни. Тому досягнення високої ефективності виробництва можливе лише за рахунок підвищення кожного із вищезазначених 
Національні витрати на НДКР в Україні у абсолютному та відносному

Таблиия 2 вираженні за 2001 - 2008 рр..

\begin{tabular}{|c|c|c|c|c|c|c|c|c|c|}
\hline № & $\begin{array}{c}\text { Назва } \\
\text { показника }\end{array}$ & 2001 & 2002 & 2003 & 2004 & 2005 & 2006 & 2007 & 2008 \\
\hline 1 & $\begin{array}{l}\text { ВВП(у } \\
\text { фактичних } \\
\text { цінах), } \\
\text { млн.грн } \\
\end{array}$ & 204190 & 225810 & 267344 & 345113 & 441452 & 544153 & 720731 & 949864 \\
\hline 2 & $\begin{array}{l}\text { Загальні } \\
\text { витрати } \\
\text { бюджету, } \\
\text { млн.грн }\end{array}$ & 55528,0 & 60318,9 & 75792,5 & 102384,8 & 141989,5 & 175512,2 & 186738,6 & 193280,8 \\
\hline 3 & $\begin{array}{l}\text { Усього } \\
\text { витрат на } \\
\text { НДКР, } \\
\text { мЛн. грн }\end{array}$ & 2450,3 & 2611,7 & 3597,4 & 4251,7 & 5160,4 & 6160,0 & 10850,9 & 11994,2 \\
\hline 4 & \% до ВВП & 1,20 & 1,16 & 1,35 & 1,23 & 1,17 & 1,13 & 1,51 & 1,26 \\
\hline 5 & $\begin{array}{l}\text { \% до } \\
\text { загальних } \\
\text { витрат } \\
\text { бюджету }\end{array}$ & 4,41 & 4,33 & 4,75 & 4,15 & 3,63 & 3,51 & 5,81 & 6,21 \\
\hline
\end{tabular}

Джерело: Статистичний щорічник України за 2001 - 2007 роки та [5, с. 3]

показників, що в свою чергу можливе лише за умов здійснення вагомих вкладень у людський капітал, сприяння розвитку інноваційного підприємництва, зміни акцентів у державній політиці регулювання оплати праці (що забезпечувала б стимулювання висококваліфікованої праці, інноваційної діяльності).

\section{Узагальнюючі показники динаміки інноваційного розвитку вітчизняних підприсмств у 2000-2008 роках}

\begin{tabular}{|c|c|c|c|c|c|c|}
\hline Роки & 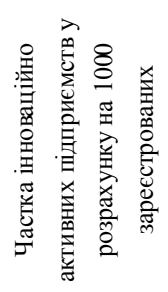 & 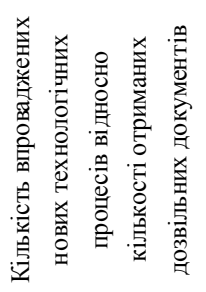 & 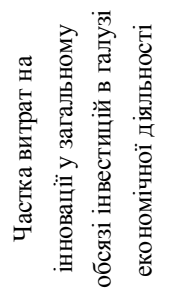 & 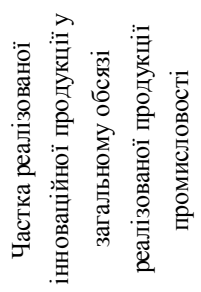 & 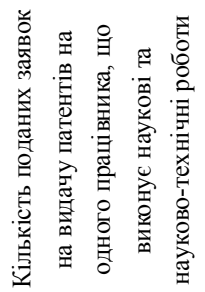 & 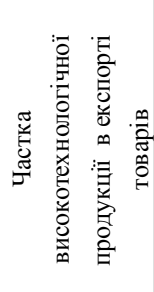 \\
\hline 1 & 2 & 3 & 4 & 5 & 6 & 7 \\
\hline 2000 & 1,7847 & 0,3481 & 0,0745 & 0,0108 & 0,0351 & 0,0170 \\
\hline 2001 & 1,6630 & 0,2066 & 0,0608 & 0,0108 & 0,0516 & 0,0160 \\
\hline 2002 & 1,5787 & 0,1907 & 0,0812 & 0,0109 & 0,0585 & 0,0180 \\
\hline 2003 & 1,5157 & 0,2027 & 0,0600 & 0,0115 & 0,0735 & 0,0240 \\
\hline 2004 & 1,4706 & 0,2264 & 0,0599 & 0,0103 & 0,0660 & 0,0240 \\
\hline 2005 & 1,4103 & 0,2385 & 0,0618 & 0,0103 & 0,0748 & 0,0110 \\
\hline 2006 & 1,2813 & 0,1500 & 0,0492 & 0,0097 & 0,0815 & 0,0130 \\
\hline 2007 & 1,1828 & 0,1895 & 0,0576 & 0,0093 & 0,0920 & 0,0120 \\
\hline 2008 & 1,1213 & 0,1962 & 0,0515 & 0,0093 & 0,0915 & 0,0120 \\
\hline
\end{tabular}

Джерело: Складено автором 
Карюк В. I.

Не менш результативним методом підвищення ефективності виробництва буде також активізація інноваційної діяльності у галузях, що відносяться до наукомістких. На сьогодні стає очевидною потреба в постійному оновленні продуктів і технологій, що змушує розвивати наукові та проектні розробки, підпорядковувати виробничу діяльність підприємства прискоренню інноваційних процесів. Це призведе до збільшення економічного ефекту від інноваційної діяльності та значного зростання ваги даних показників. Техніко-технологічний рівень виробництва $є$ основним джерелом зростання ефективності промислового виробництва, що не має меж i визначається науково-технічним прогресом, техніко-технологічним удосконаленням виробництва, появою нових матеріалів та видів енергіï.

Отже, для забезпечення підвищення ефективності промислового виробництва у довгостроковій перспективі Україні знадобиться стимулювати інвестиції та інновації, покращити інституційну та законодавчу складові бізнесуклімату, і створити умови для розвитку вільної конкуренції.

Виходом із ситуації, що склалася в економіці, $\epsilon$ кардинальна перебудова економічної політики, удосконалення організаційно-економічного механізму економічної діяльності у напрямку інноваційного розвитку та одночасний пошук резервів підвищення ефективності виробництва для його забезпечення.

Висновки та пропозиції. Досягнення Україною високих показників показників економічного розвитку можливе лише за рахунок комплексного та системного здійснення таких заходів, що в сукупності з іншими факторами та складовими формують оновлену модель організаційноекономічного механізму розвитку інноваційної діяльності:

- підвищення результативності сектору наукових досліджень і розробок з метою його перетворення у ключову ланку інноваційного розвитку національної економіки;

- забезпечення розвитку системи фінансовокредитної підтримки реалізації конкурентоспроможних науково-технічних та інноваційних програм і проектів;

технологічного переобладнання і структурної перебудови виробництва 3 метою нарощення випуску товарів, конкурентоспроможних на світовому і внутрішньому ринках;

- розвитку системи науково-технічних комунікацій і трансферу технологій;

сприяння розвитку виробничо-технологічної інфраструктури інноваційної діяльності;

- розвитку наукового та винахідницького потенціалу, необхідного для розробки нових поколінь техніки та технологій та забезпечення конкурентоспроможності національної економіки;

- запровадження ефективних механізмів державно-приватного партнерства, спрямованих на досягнення конкурентоспроможності вітчизняної продукції на світовому ринку у окремих секторах наукоємного виробництва переважно за рахунок впровадження технологій вітчизняної розробки.

Створення організаційно-економічного механізму стимулювання інноваційної діяльності в кінцевому підсумку повинно привести до забезпечення стабільності економічного стану країни і стати однією із основних складових стратегії державної інноваційної політики.

\section{Список літератури}

1. Проект розпорядження Кабінету Міністрів України "Про схвалення Концепції розвитку національної інноваційної системи", направлено на розгляд Кабінету Міністрів України листом Держінвестицій від 15.10.2008 року № 2691/01-061-3-03 // офіційний сайт Державного агентства України 3 інвестицій та інновацій: http:// www.in.gov.ua.

2. Науково-практичний бюлетень "Інвестиції та інноваційний розвиток, 2008" / Офіційне видання державного агентства України 3 інвестицій та інновацій. Київ, 2, 2009. - 64 с.

3. Покришка Д.С., Жаліло Я.А., Шкадюк В.Б. Еволюція та перспективи конкурентоспроможності економіки України / Україна в 2005-2009 pp.: стратегічні оцінки суспільно-політичного та соціально-економічного розвитку. Монографія. К.: - 2009. - 644 с.

4. Тульчинська С.О. Функціонування організаційно-економічного механізму інноваційного процесу//Стратегічні пріоритети, №1(6), 2008 p., c. 89 - 95.

5. Шевченко Л.С. Професійна освіта як чинник конкурентоспроможності робочої сили / Демографія та соціальна економіка Науковоекономічний та суспільно-політичний журнал/К.: НАН України Інститут демографії та соціальних досліджень, 2, 2008. - 207 с.

6. A Time for New Ideas: Innovation in Central Eastern Europe // Economist Intelligence Unit, Oracle. - London: EIU, 2008. 
Аннотация

В.Карюк

\section{ОРГАНИЗАЦИОННО-ЭКОНОМИЧЕСКИЙ МЕХАНИЗМ АКТИВИЗАЦИИ ИННОВАЦИОННОЙ ДЕЯТЕЛЬНОСТИ ПРЕДПРИЯТИЙ}

Исследовано понятие и механизм осуществления инновационной деятельности, ее роль в развитии экономики государства, проанализированы основные тенденции инновационного развития промышленных предприятий в Украине. Усовериенствована система показателей для оценки инновациинного развития предприятий. Выявлены основные проблемы, препятствующие эффективному развитию инновационной деятельности отечественных предприятий на современном этапе и определены основные пути активизации инновационной деятельности.

Ключевые слова: инноваџионная деятельность, инноваџионный потенциил, организационноэкономический механизм, промышленное производство, эффективность.

\section{Summary}

V.Karyok

\section{ORGANIZATIONAL AND ECONOMIC MECHANISM OF PROMOTION OF INNOVATIVE ACTIVITIES OF ENTERPRISES}

The article examines the concept and mechanism of innovation, its role in the development of national economy, the main trends of development of innovation processes in industrial enterprises in Ukraine. The system of indicators for measure innovation of enterprises. The author submits the main problems that hinder the effective development of innovation activities of domestic enterprises at the present stage and the author defines the main ways to accelerate innovation activity.

Keywords: Innovation activity, innovation capacity, organizational and economic mechanism, industrial production, efficiency. 
УДК:331.105(477)

(C) Запухляк В.М., Грунтковський В.Ю., 2011

Чернівецький національний університет імені Юрія Федьковича, м. Чернівці

\section{ПРОБЛЕМИ ТА ПЕРСПЕКТИВИ РОЗВИТКУ СОЦІАЛЬНО ВІДПОВІДАЛЬНОГО БІЗНЕСУ В УКРАЇНІ}

Обгрунтована необхідність впровадження принципів соиіальної відповідальності бізнесу у практику господарювання підприємствами. Визначено основні проблеми та стимули ї̈ впровадження у вітчизняних умовах. Указано на необхідність побудови загальнонаціональної моделі соціальної відповідальності бізнесу.

Ключові слова: сочіальна відповідальність, стандарти сочіальної відповідальності, конкурентоспроможність.

Українська економіка перебуває на початковому етапі усвідомлення та формування власної моделі соціальної відповідальності. Тому значну увагу з боку громадських організацій та владних інституцій необхідно спрямувати саме на вироблення вітчизняної моделі соціальної відповідальності, яка б відображала особливості культурного, економічного та правового розвитку національної економіки. Про важливість розроблення національної концепції соціальної відповідальності можуть свідчити результати досліджень, що проводилися в різних регіонах країни.

Важливою особливістю сучасної парадигми формування соціально-трудової сфери $є$ визнання соціальної відповідальності підприємства як перед суспільством, покупцями, партнерами, так і перед людьми, що працюють в організації. Даний напрямок почав розвиватися в $1960-$ х роках, коли взялася під сумнів теза про єдину мету суб'єктів бізнесу - отримання прибутку, що спричинило вивчення питань про необхідність визнання соціальної відповідальності. Незважаючи на широке розповсюдження даного напрямку за кордоном, в Україні його теоретична розробка та практичне впровадження лише розпочинається.[1, ci 11]

Дослідженням соціальної відповідальності бізнесу присвятили свої праці такі закордонні вчені як Г.Боуен, К. Девіс, М. Фрідман, Е. Фрімен, Д. Елкінгтон, А. Керолл, Д. Мун, П. Друкер, Т. Бредгард, Ф. Котлер, Ю. Благов, С. Літовченко та інші.

В Україні це питання набуло актуальності порівняно не так давно, однак цей напрямок достатньо актуальний на сьогодні. Серед вітчизняних науковців, які досліджують питання соціальної відповідальності можна виділити праці Ю. Саєнко, П. Яницького, Г. Назарова, Г. Попович, І. Акімова, О. Осінкіна, О. Філіпченко та інші.

Соціальна відповідальність - один із тих

факторів, що впливає на загальну економічну ефективність діяльності підприємств. Однак це досягається тільки за умови постійної діяльності в сфері корпоративної соціальної відповідальності. Усвідомлення цього факту, безперечно, призведе до підвищення уваги бізнес-одиниць до питань, що відображають роботу у напрямку підвищення загального рівня реагування на вимоги стейкхолдерів.

Незважаючи на достатньо велику частку компаній, обізнаних із соціальною відповідальністю в регіонах, дані аналізу, проведеного у 2008 році, свідчать, що більше ніж третина організацій $(36,4 \%)$ вважають, що розвиток соціальної відповідальності в їх регіоні знаходиться на рівні "нижче середнього", 28,3\% організацій - на "середньому" рівні, майже кожна п'ята організація (19,2\%) - на "низькому" рівні, а кожна десята організація $(10,1 \%)$-на "дуже низькому" рівні. Тільки 6\% організацій вважають, що розвиток соціальної відповідальності в їх регіоні знаходиться на "високому" та "вище середнього" рівнях [2, с. 53].

Показниками соціальної відповідальності в середовищі українських компаній переважно розуміють надання благодійної допомоги громаді, розвиток власного персоналу, чесне ведення бізнесу та дотримання і захист прав людини. Найменше асоціюють із соціальною відповідальністю впровадження принципів і практик підзвітності, прозорості й етичної поведінки, здійснення екологічних проектів та участь у регіональних програмах розвитку (див. табл. 1).

Загального визнання у середовищі малого і середнього бізнесу України набули твердження про те, що умовою соціальної відповідальності має бути дотримання законодавства про працю i охорону навколишнього середовища $(82,5)$, та те, що відповідальні компанії виконують набагато більше, ніж зазначено за законом задля позитивного впливу на суспільство і навколишнє 
середовище $(70,8)$. Промовистою $є$ думка опитаних 3 приводу того, що КСВ має бути врегульована на законодавчому рівні для іiі швидшого поширення $(78,2)$. Високий рейтинг серед запропонованих посідає також твердження про те, що діяльність. КСВ повинна передбачати заходи щодо захисту навколишнього середовища $(77,7)[3]$.

\section{Складові соціальної відповідальності бізнесу}

\begin{tabular}{|c|l|c|c|}
\hline $\begin{array}{c}\text { № } \\
\text { п/п }\end{array}$ & \multicolumn{1}{|c|}{ Показники } & $\mathbf{2 0 0 5}$ & $\mathbf{2 0 1 0}$ \\
\hline $\mathbf{1 .}$ & $\begin{array}{l}\text { Впровадження соціальних програм поліпшення умов праці } \\
\text { власного персоналу }\end{array}$ & 65,5 & 57,8 \\
\hline $\mathbf{2 .}$ & Навчання/розвиток персоналу & 63,2 & 57,8 \\
\hline $\mathbf{3 .}$ & Благодійна допомога & 56,0 & 58,1 \\
\hline $\mathbf{4 .}$ & Застосування в політиці компанії принципів & 49,5 & 42,3 \\
\hline $\mathbf{5 .}$ & Участь в регіональних програмах розвитку & 32,3 & 30,5 \\
\hline $\mathbf{6 .}$ & Реалізація екологічних програм & 29,8 & 30,7 \\
\hline $\mathbf{7 .}$ & Відкрите подання інформації про діяльності компанії & 18,7 & 24,5 \\
\hline
\end{tabular}

Серед основних перешкод, 3 якими зустрічаються компанії при впровадженні соціальних проектів, найчастіше вказуються фінансові, зокрема обмеженість фінансових можливостей та нестача коштів для тих, хто потребує $(48 \%)$, а також недосконалість нормативно-правової бази, в тому числі законодавства щодо соціальних проектів (31\%). Значно менше, проте зазначаються: організаційні труднощі (8\%); забюрократизованість процесу надання допомоги (5\%); відносно високі запроси отримувачів благодійної допомоги (5\%); тиск 3 боку органів влади (3\%); неможливість контролювати розподіл коштів (3\%) та корупція $(2 \%)[7]$.

За дослідженням 2005 року дефіцит фінансових ресурсів та відсутність законодавства, яке б регулювало проведення заходів з СВБ, є найбільш поширеними відповідями при опитуванні щодо перешкод для проведення цієї діяльності (55\%) фірм відмітило фінансовий фактор, а 45,9\% фактор законодавства, в той же час у 2010 році $61,4 \%$ компаній визначили основною проблемою у впровадженні соціальної відповідальності брак коштів. Так, аналіз 2005 року показав, що демотиваторами при впровадженні соціальної відповідальності можуть також виступати проблеми із контролем за використанням коштів, що направляють на СВБ програми, тільки $17 \%$ фірм скаржились на недостатність допомоги 3 боку державних та недержавних організацій та на недостатність інформації про потреби громадськості. Результати опитування 2010 року показали, що 15,9\% компаній навіть не замислювалися про соціальну відповідальність. Ця відповідь повинна вказувати на необхідність популяризації концепції соціальної відповідальності в суспільстві.

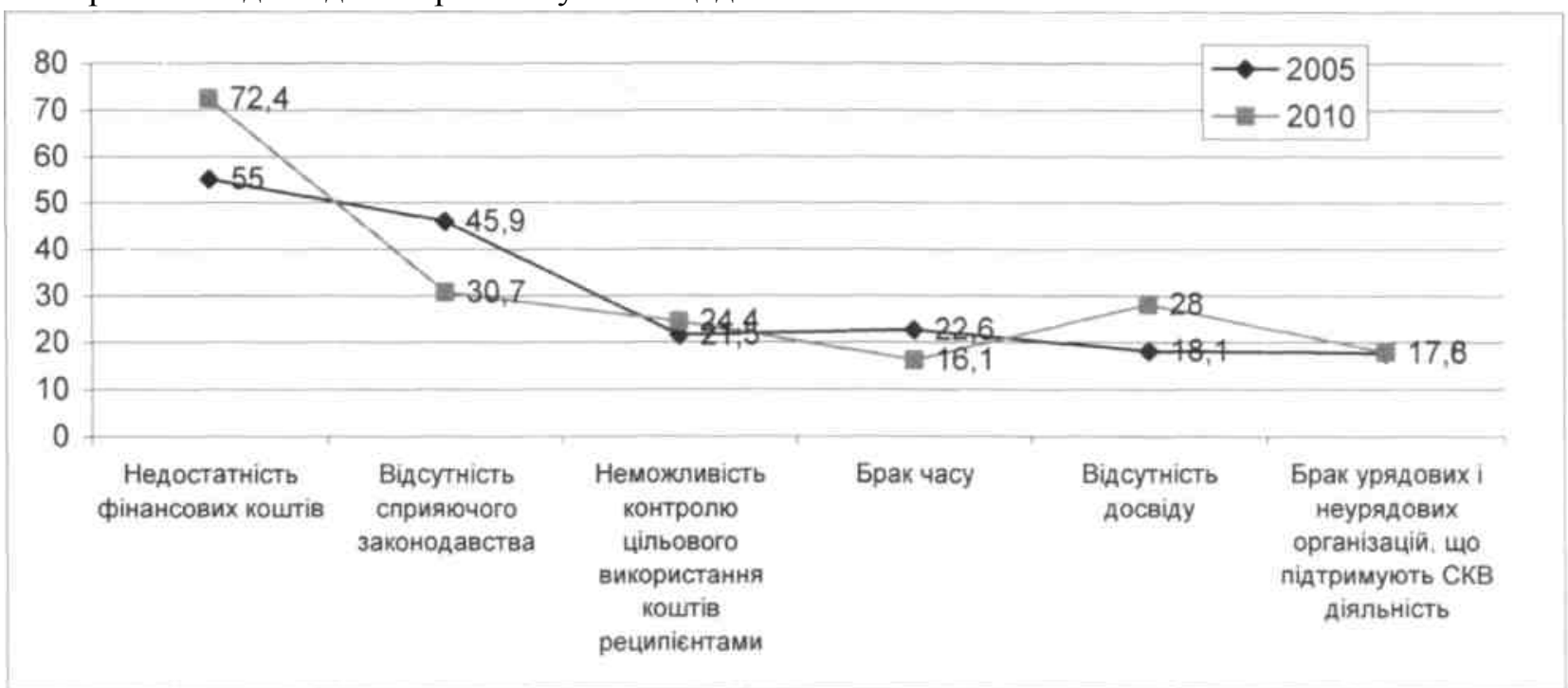

Рис. 1. Перешкоди для імплементації соціальної відповідальності 
Запухляк В. М., Грунтковський В. Ю.

Па практиці понад 50\% і більше організацій, які формують політику/стратегію соціальної відповідальності, впроваджують такі компоненти соціальної відповідальності, як: - права людини $(71 \%)$; соціальне залучення і соціальний розвиток $(58 \%)$. Інші компоненти соціальної відповідальності впроваджують більше третини опитаних організацій; організаційне управління $45 \%$; екологічні питання - $48 \%$; трудові практики - 46,5\%; питання споживачів - 43\%; практика чесного введення бізнесу - 40,5\% [2, с.9]. Однак вищеперелічені практики, нажаль носять суто декларативний характер і визначити ефективність даних заходів досить складно.

За регіонами спостерігаються наступні відмінності. Брак фінансів найчастіше відзначався у Харкові $(78,4 \%)$ та Львові $(71,2 \%)$. Недостатній розвиток законодавства $\epsilon$ найбільшою перешкодою для підприємств Дніпропетровська $(52,4 \%)$. На брак інформації про потреби громадськості у вирішенні питань, пов'язаних із проведенням заходів з СВБ, скаржилось $41 \%$ фірм у Львові. У Києві та Донецьку тільки четверта частина компаній відмітила недостатню наявність організацій, що могли б допомогти у здійсненні цих програм [8, с.15].

Можна виділити та проранжирувати групу показників, що перешкоджають упровадженню соціальної відповідальності у практику господарювання:

1. Дефіцит фінансових ресурсів.

2. Недосконалість (відсутність) нормативноправової бази.

3. Відсутність стимулів.
4. Відсутність прозорих механізмів контролю за використанням коштів, спрямованих на соціальну відповідальність.

5. Відсутність спеціальних навичок та знань.

6. Відсутність бачення потенційних вигід від впровадження соціальної відповідальності.

Окресливши основні проблеми 3 якими стикаються вітчизняні підприємства у питанні запровадження заходів соціальної відповідальності у практику господарювання, доцільно виділити ті фактори, які є стимулами у її впровадженні.

Аналіз факторів, що спонукають до впровадження соціальної відповідальності у 2010 році майже не змінились у порівнянні 2005 роком. Більшість компаній $(61,3 \%)$ основним мотивом виділили моральні міркування, як базовий принцип та внутрішне спонукання для компанії виділяють $52,1 \%$ компаній.

Варто враховувати, що різні регіони України мають різний промислово-виробничий комплекс, відповідно специфіка кожного регіону вимагатиме врахування особливостей структури галузевої специфікації. Зосередження промислових гігантів на сході, які входять до основних вітчизняних фінансово-промислових груп, безпосередньо впливатиме на рівень розвитку соціальної відповідальності в цих регіонах. Водночас у західних регіонах, здебільшого, розвинута сфера торгівлі та агропромисловий комплекс. Не сформованість аграрного ринку та наявність "тіньових" схем у роботі торгівельних підприємств носитиме негативний характер по відношенню до концепції соціальної відповідальності.
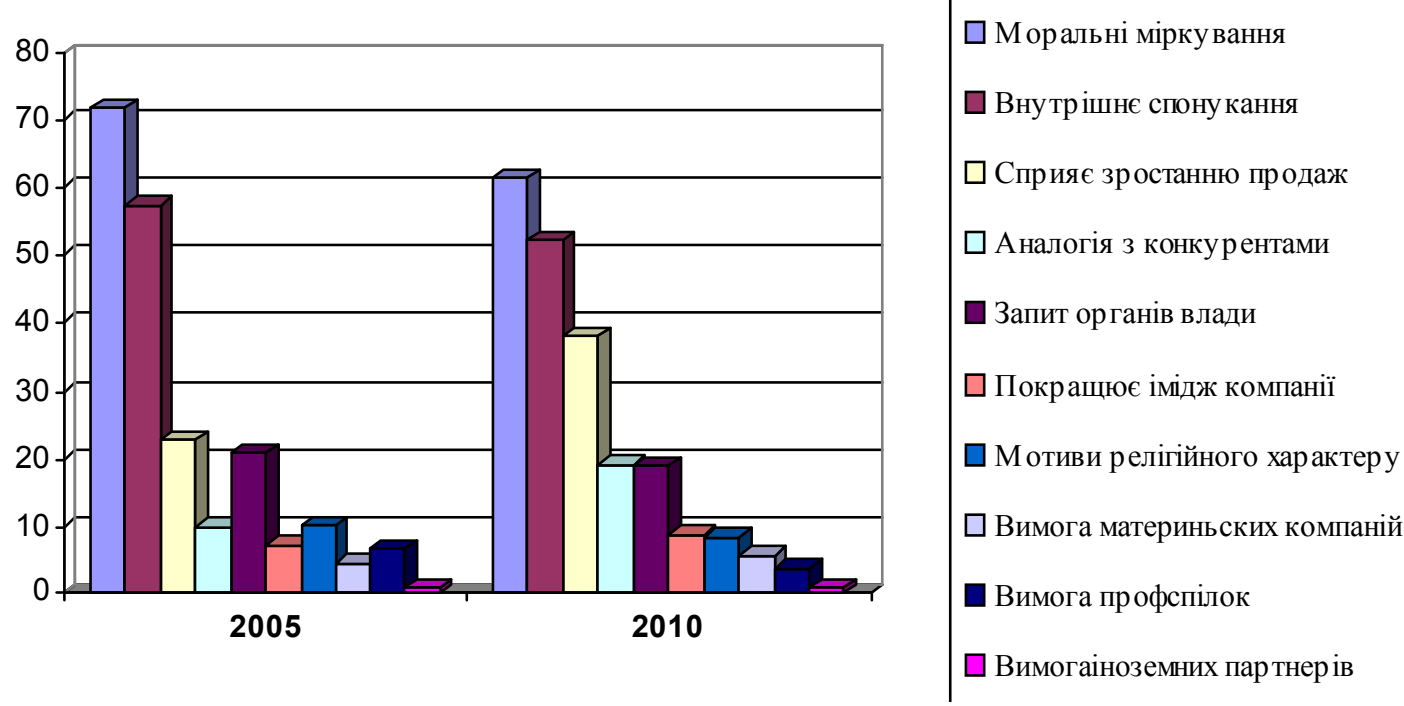

Рис. 2. Чинники, що спонукають компанію здійснювати соціально відповідальні заходи 
Виходячи $з$ проведеного аналізу, можна зробити висновок, що більшість компаній переходять від благодійної діяльності до соціальних інвестицій, спрямованих на вирішення найбільш гострих соціальних проблем у сфері освіти, охорони здоров'я, зайнятості, житла. Це дозволить не тільки підтримувати баланс інтересів ділової спільноти з інтересами держави і суспільства, а й забезпечить позитивний ефект від управління соціальним інвестуванням як для самих організацій, так і для суб'єктів соціальної сфери.

Важливо, що формування єдиних стандартів соціальної відповідальності бізнесу сприятиме розширенню зовнішньоекономічних зв'язків, створенню сприятливого інвестиційного клімату, зміцненню конкурентоспроможності корпоративних секторів.

\section{Список літератури}

1. Гончарова С.Ю., Водницька Н.В. Соціальна відповідальність та роль компенсаційного пакету в $\dddot{11}$ формуванні // Научные труды ДонНТУ. Серия: экономическая. Выпуск 103-2 - 2006 - С. 111-118

2. Зінченко А.Г. Соціальна відповідальність в Україні: Погляди різних стейкхолдерів. Регіональний аспект / А.Г. Зінченко, М.А. Саприкіна. - К., 2008. - 60 c.

3. Корпоративна соціальна відповідальність малого та середнього бізнесу [Електронний ресурс].

Режим доступу: http:/www.csr-ukraine.org/ userfiles/file/4 CSR\%20among\%20SMEs.pdf

4. Новий курс: реформи в Україні. 2010-2015. Національна доповідь / за заг. ред. В. М. Гейця [та ін.]. - К.: НВЦНБУВ, 2010. - 232 с.

5. Осецький В.Л. Соціальна відповідальність корпорацій України як фактор забезпечення їхньої конкурентоспроможності / В.Л. Осецький, В.М. Марченко // Економіка та держава -2007 - №1 - С 9-12

6. Посібник із корпоративної соціальної відповідальності / Лазоренко О., Колишко Р.. - К.: Видавництво "Енергія", 2008. - 96 с.

7. Соціальна відповідальність бізнесу в Україні / Відп. ред.: Ю. Саєнко. - К.: "Батискаф", 2002.-71 с.

8. Соціальна відповідальність українського бізнесу. Результати опитування Київ "КIT" - 2005 - 52с

\section{Аннотация}

Владимир Запухляк, Владимир Грунтковский

\section{ПРОБЛЕМЫ И ПЕРСПЕКТИВИ РАЗВИТИЯ СОЦИАЛЬНО ОТВЕТСТВЕННОГО БИЗНЕСА В УКРАИНЕ}

Обоснована необходимость внедрения принципов соииальной ответственности бизнеса в практику хозяйствования предприятиями. Определены основные проблемы и стимулы ее внедрения в отечественных условиях. Указано на необходимость построения общенациональной модели социальной ответственности бизнеса.

Ключевые слова: социальная ответственность, стандарты сочиальной ответственности, конкурентоспособность.

\section{Summary}

Volodymyr Zapukhlyak, Volodymyr Gruntkovskiy

\section{ISSUES AND PROSPECTS FOR SOCIALLY RESPONSIBLE BUSINESS DEVELOPMENT IN UKRAINE}

The article justifies the need for corporate social responsibility in the business-practice of enterprises. The paper identifies key issues and incentives for its implementation in domestic conditions. The need to create a national model of corporate social responsibility is specified by the authors.

Keywords: social responsibility, standards of social responsibility, competitiveness. 
УДК 338.242

(C) () Белінський П.І., 2011

Чернівецький національний університет імені Юрія Федьковича, м. Чернівці

(C) Загриновський М.В., Рубенок Т.М., 2011

Національний технічний університет,

Харківський політехнічний інститут, м. Чернівці

\section{ЕФЕКТИВНІСТЬ РОБОТИ ПІДПРИЕМСТВА НА ДАВАЛЬНИЦЬКІЙ СИРОВИНІ ТА ФІНАНСОВО-ЕКОНОМІЧНА БЕЗПЕКА ЙОГО ДІЯЛЬНОСТІ}

Аналізуються проблеми діяльності підприємства, що праџює на умовах використання давальницької сировини, його взаємозв'язки в системі міжнародних комериійних процесів $i$ визначається механізм формування фінансово-економічної безпеки фірми.

Ключові слова: давальнищька сировина, кооперація, технічне переозброєння, конкурентоспроможність, продуктивність, ефективність.

Постановка проблеми. Кризова ситуація в економічній сфері пострадянського простору, як наслідок руйнування єдиної загальнодержавної системи суспільного розподілу праці, призвела до того, що операції $з$ давальницькою сировиною в зовнішньоекономічній діяльності набули широкого застосування [2. с. 100-113] . На етапі формування економіки незалежної України такі заходи стали важливим засобом виходу 3 економічної кризи багатьох підприємств. Вони істотно вплинули на соціально-економічне становище суб'єктів господарювання, що зумовлює необхідність продовження вивчення цих процесів, їх впливу на фінансово-економічну безпеку підприємств-переробників давальницької сировини та ії постачальників.

Аналіз останніх досліджень та публікацій. Проблемі застосування операцій з давальницькою сировиною в господарській діяльності підприємств у своїх працях приділяють увагу С. Авдашева, О.П. Гребельник, Г.М., Дроздова, В.Є. Житний, I. Нижній, Л.Пісьмаченко, С.Чорнокондратенко, С. Чудина та ін. Проте, теоретичні та практичні аспекти використання давальницьких операцій в зовнішньоекономічній діяльності вітчизняних підприємств у контексті забезпечення їх фінансово-економічної безпеки досліджені ще не достатньо. Вивчення цих питань сприятиме більш ефективному використанню давальницької сировини і підвищенню зацікавленості в цих діях підприємств-замовників і підприємств виконавців.

Постановка завдання. Важливою для підприємства-переробника давальницької сировини $є$ потреба у вивченні і оцінці його економічної безпеки, як самостійної економічної категорії, притаманної ринковій економіці. У зв'язку з цим доцільно дослідити аспекти і механізми формування економіки підприємства через поняття науково-технічного прогресу, інвестиційної та інноваційної діяльності [3. с. 2123].

Виклад основного матеріалу. Перехід України до ринкової системи господарювання зумовив значні зміни умов і принципів діяльності підприємств, що суттєво відобразилось на їх фінансово-економічних результатах. Передбачалося, що з роздержавленням власності, зміною організаційно-правового статусу підприємств будуть створені сприятливі економічні умови для виробництва продукції, яка користується попитом на ринку і забезпечує отримання прибутку в розмірах, необхідних для саморозвитку та розширеного відтворення , задоволення економічних інтересів усіх учасників виробництва. Проте ефективність виробництва не лише не підвищилась, а навіть знизилась. Не відбулось радикального збільшення прибутковості промислових підприємств, значно зросла частка збиткових підприємств і сума отриманих збитків.

Прикладом таких підприємницьких структур, що опинились в описаній вище ситуації, можуть бути вітчизняні підприємства легкої промисловості. У ході приватизації вони опинилися в непередбаченому та нестабільному ринковому середовищі. 3 одного боку, колишні партнери у межах галузі перетворилися на конкурентів, 3 іншого - на утвореному ринку домінує дешевша продукція іноземних виробників. Тому 3 метою збереження своєї діяльності зміцнення виробничого потенціалу та підвищення 
ЕФЕКТИВНІСТЬ РОБОТИ ПІДПРИСМСТВА НА ДАВАЛЬНИЦЬКІЙ СИРОВИНІ ТА ФІНАНСОВОЕКОНОМІЧНА БЕЗПЕКА ЙОГО ДІЯЛЬНОСТІ

конкурентоспроможності продукції підприємствам необхідно було пристосуватися до ринкових умов господарювання .

Одним із напрямків такої адаптації виробників до нових реалій економічного життя є кооперація вітчизняних підприємств із зарубіжними партнерами на основі переробки давальницької сировини. Від реалізації даних кооперативних зв'язків в значній мірі залежить соціальноекономічний розвиток багатьох підприємств, обсяги виробництва, завантаженість основних виробничих потужностей, зайнятість персоналу, розширення зовнішніх і внутрішніх ринків збуту продукції тощо. На виконання цих завдань був спрямований і закон України "Про операції 3 давальницькою сировиною у зовнішньоекономічних відносинах", який введений в дію постановою Верховної ради в 1995 році і за роки після його прийняття чотирнадцять разів доповнювався новими положеннями, що $\epsilon$ переконливим свідченням актуальності цією проблеми 1.. Підтвердженням успішності таких кооперативних зв'язків є багаторічний досвід роботи 3 давальницькою сировиною ТзДВ "Трембіта" м. Чернівці.

На основі укладення контрактів та договорів 3 іноземними фірмами, пов'язаних 3 переробкою давальницької сировини, підприємство отримало можливість за короткий час здійснити технічне переозброєння, впровадити нові технології,

\begin{abstract}
підвищити якість виробів та конкурентоспроможність як на внутрішньому, так i на зовнішньому ринках. Більше уваги приділяється матеріальній зацікавленості працівників, мотивації та поліпшенню умов праці трудового колективу.
\end{abstract}

Важливим елементом технологічного оновлення на підприємстві було придбання машин та обладнання, призначених для розкрою тканин та пошиву виробів. Справжнім науково-технічним проривом було придбання і використання розкрійних столів. Переваги їх перед розкроєм вручну не лише у високій продуктивності, а й у тому, що виконання процесу згідно комп'ютерної програми практично виключає брак у проведенні цієї роботи і зменшує істотно відходи тканин. До переваг розкрійних столів належить віднести і те, що вони мінімізують вплив людських емоцій, які можуть мати місце при виконанні цих робіт розкрійниками.

Підвищенню якості робіт, продуктивності праці сприяє також впровадження потокового методу пошиву швейних виробів, зокрема чоловічих костюмів, які складають основний асортимент продукції підприємства. Упровадження потокового виробництва дозволило ефективно використати у виробничому процесі високотехнологічні швейні машини відомих західних фірм Дюркопп, Джуки, Рамольді та ін. 9. 172 с. . Характеристика окремих 3 них наведена в таблиці 1.

Технічна характеристика деякого швейного обладнання потокових цехів ТзДВ "Трембіта"

\begin{tabular}{|c|c|c|c|}
\hline $\begin{array}{c}\text { Тип,клас } \\
\text { обладнання }\end{array}$ & $\begin{array}{c}\text { Завод - } \\
\text { виробник }\end{array}$ & $\begin{array}{c}\text { Tехнічна характеристикашвейного } \\
\text { обладнання }\end{array}$ & $\begin{array}{l}\text { Вартість } \\
\text { утис.грн. }\end{array}$ \\
\hline $\begin{array}{l}697-151155 \\
\text { кл. голка } \\
\text { ДР*35 R }\end{array}$ & $\begin{array}{c}\text { Дюркопп } \\
\text { Н імеччина }\end{array}$ & 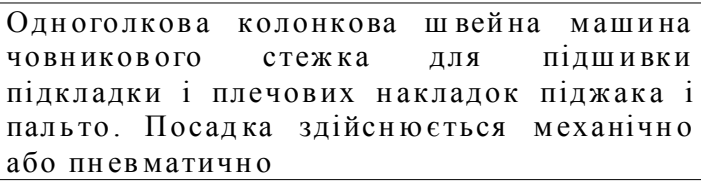 & 32,5 \\
\hline $\begin{array}{l}\text { MEB } 3200 \\
\text { SSM голка } \\
558\end{array}$ & Дж уки & $\begin{array}{l}\text { Електронна петельна машина ланцюгового } \\
\text { стежка для глазкових петель. Машина } \\
\text { може викладати петлі } 3 \text { прокладанням } \\
\text { каркасної нитки і прорубкою до або після } \\
\text { шиття. Довжина петлі від } 10 \text { до } 40 \text { мм., } \\
\text { піднятяя лапки до } 16 \text { мм. Обладнання } \\
\text { новою електронною системою натягування } \\
\text { нитки, укомплектована } \\
\text { обрізання механізмом } \\
\text { Швидкість до } 2200 \text { ст./хв.. }\end{array}$ & 74,3 \\
\hline
\end{tabular}


У виробничому процесі задіяні також інші прогресивні технології. Виправдав себе процес використання ліній волого-теплової обробки швейних виробів, який позитивно вплинув на зростання продуктивності праці працівників пошивочних цехів і суттєве зменшення витрат на виготовлення продукціі.

Особливо позитивну роль ці заходи відіграли в період роботи ТзДВ "Трембіта" на давальницькій сировині, коли доходи підприємства значно стали залежати перш за все від рівня продуктивності праці, кількості виготовлених швейних виробів.
Згідно 3 діючою на підприємстві технологією тканини призначені для виготовлення того чи іншого швейного виробу, надходять до розкрійного цеху. Після розкрою складові частини запланованого виробу комплектують у пакет i спрямовують у потоковий цех для пошиву.

Усі ці зміни, пов'язані з технічним оновленням i переозброєнням виробництва, дозволили поглибити поділ праці з урахуванням неподільності операцій, мінімізувати затрати часу на їх проведення (таблиця 2).

\section{Склад неподільних операцій при виготовленні чоловічого піджака та показник витрат часу на їх проведення}

\begin{tabular}{|c|c|c|c|}
\hline $\begin{array}{l}\text { № } \\
\text { ПI/II }\end{array}$ & $\begin{array}{c}\text { К-ть } \\
\text { операцій }\end{array}$ & Перелік основних операцій обшиван ня & $\begin{array}{l}\text { Затрати } \\
\text { часу, сек. }\end{array}$ \\
\hline 1. & 16 & $\begin{array}{l}\text { Намітити лінію перегину, обточування борту, } \\
\text { розташування верхньої кишені. Вивернути клапани на } \\
\text { лицеву сторону та ін.. }\end{array}$ & 318 \\
\hline 2. & 21 & $\begin{array}{l}\text { Розпрасувати шов зшивання бічних частин пілочки. } \\
\text { Прошити мішковину нагрудної кишені ... }\end{array}$ & 576 \\
\hline 3. & 17 & Закріпити бортову прокладку на поперечину лацкана ... & 484 \\
\hline 4. & 22 & Розпрасувати шов прошивання стійки ... & 535 \\
\hline 5. & 18 & Нашити фірмову етикетку. Пришити підкладку. & 942 \\
\hline 6. & 20 & $\begin{array}{lllll}\text { Прошити стійку до верх нього } & \text { коміра. } & \text { Прошити } \\
\text { підкладку до низу рукавів ... } & & \\
\end{array}$ & 639 \\
\hline 7. & 20 & Припасувати передній і ліктьовий шви рукава ... & 634 \\
\hline 8. & 20 & Нашити плечові накладки по проймі піджака ... & 558 \\
\hline 9. & 18 & $\begin{array}{l}\text { Перевірити ширину уступів лацкана і довжину бортів } \\
\text { пілочки піджака. }\end{array}$ & 848 \\
\hline 10. & 19 & Підібрати рукави по номеру ... & 461 \\
\hline 11. & 6 & $\begin{array}{l}\text { Почистити піджак від виробничого сміття. Подати } \\
\text { роботу контролерам }\end{array}$ & 461 \\
\hline разом & 197 & & 6891 \\
\hline
\end{tabular}

Вплив інноваційних процесів на проведення неподільних операцій потоковим цехом 3 виготовлення чоловічих штанів наведено в таблиці 3.

Освоєння потокового методу коопераційної організації праці забезпечило значне підвищення продуктивності праці на підприємстві (таблиця 4).

Отже, завдяки інноваційним заходам витрати часу на пошиття чоловічого піджака у 2010 році становили 6861 секунд або 1,91 годин, а штанів відповідно 2757 і 0,76, без урахування витрат на дублювання та волого-теплову обробку виробу. Якщо їх внести в розрахунок, то загальні витрати часу на виготовлення одного чоловічого піджака становили 2,17 годин і штанів 0,98 годин або за робочу зміну, тривалість 8 годин, у середньому кожна швея цеху виготовляла 3,68 чоловічих піджаків і 8,1 одиниці штанів. У 1990-1995-ті роки минулого століття, до впровадження нових технологій, кожний працівник потокового цеху за зміну виготовляв лише 1,4 чоловічого піджака i 3 одиниці чоловічих штанів, як це зображено на рис.1.

Зростанню продуктивності праці на підприємстві сприяло збільшення виробництва швейних виробів $з$ давальницької сировини. При умові збільшення попиту, обсяг пошиву чоловічих костюмів може досягти 3000 і більше одиниць на рік проти 160 тисяч виготовлених за останні роки.

ТзДВ "Трембіта" співпрацю $з$ іноземними фірмами на давальницькій сировині вважає вигідною для обох сторін і готова її продовжувати 


\section{Склад неподільних операцій та показники витрат часу на виготовлення}

Таблиия 3. одиниці виробу (штанів за сек.)

\begin{tabular}{|c|c|l|c|}
\hline $\begin{array}{c}\text { № } \\
\text { п/п }\end{array}$ & $\begin{array}{c}\text { К-ть } \\
\text { операцій }\end{array}$ & \multicolumn{1}{|c|}{ Скорочений перелік операцій } & $\begin{array}{c}\text { Затрати } \\
\text { часу, } \\
\text { сек. }\end{array}$ \\
\hline 1. & 19 & $\begin{array}{l}\text { Нарізати тасьму «блискавку». Настрочити корсаж на } \\
\text { поли }\end{array}$ & 272 \\
\hline 2. & 21 & $\begin{array}{l}\text { Настрочити розмірний признак на поли. Припасувати } \\
\text { шов, відкол }\end{array}$ & 348 \\
\hline 3. & 22 & $\begin{array}{l}\text { Закріпити верхній край кишень. Прошити відколок до } \\
\text { правової половини. }\end{array}$ & 401 \\
\hline 4. & 24 & $\begin{array}{l}\text { Зшити бокові шви штанів. Підібрати пояси і шлівки по } \\
\text { кольору. }\end{array}$ & 655 \\
\hline 5. & 26 & Припасувати шов пришивання пояса. & 531 \\
\hline 6. & 21 & Підшити пояс. Закріпити шлівки по низу. & 2757 \\
\hline разом & 133 & \multicolumn{2}{|c}{} \\
\hline
\end{tabular}

Техніко-економічні показники пошиву чоловічого піджака

Таблиия 4. і штанів моделі 7713 (затрати часу)

\begin{tabular}{|c|c|c|c|c|}
\hline \multirow[t]{2}{*}{ Показники } & \multicolumn{4}{|c|}{ Затрати часу на: } \\
\hline & Пошив виробу & $\begin{array}{c}\text { Дублювання } \\
\text { матеріалу }\end{array}$ & $\begin{array}{l}\text { Волого-теплову } \\
\text { обробку в иробу }\end{array}$ & Усього \\
\hline \multicolumn{5}{|l|}{$\begin{array}{l}\text { 1. Затрати часу на } \\
\text { виготовлення одного } \\
\text { піджака }\end{array}$} \\
\hline секунд & 6861 & 349 & 590 & 7830 \\
\hline годин & 1,91 & 0,10 & 0,16 & 2,17 \\
\hline $\begin{array}{l}\text { Продуктивність } \\
\text { праці } \\
\text { працівника, за зміну } \\
8 \text { годин }\end{array}$ & 4,19 & - & - & 3,68 \\
\hline \multicolumn{5}{|l|}{$\begin{array}{l}\text { 2. Затрати часу на } \\
\text { виготовлення } \\
\text { одиниці } \\
\text { (штанів) }\end{array}$} \\
\hline секунд & 2757 & 275 & 497 & 3519 \\
\hline годин & 0,76 & 0,08 & 0,14 & 0,98 \\
\hline $\begin{array}{l}\text { Продуктивність } \\
\text { праці працівника за } \\
\text { 3міну (8 год.) }\end{array}$ & 10,5 & - & - & 8,1 \\
\hline
\end{tabular}

на умовах контрактів, які діють на даний час 6. c. 24-25.

Згідно контракту "Замовник", як постачальник сировини, бере на себе найменування, маркування та вартість сировини, які є його невід'ємною частиною. Маркування швейних виробів проводиться етикетками виготовленими iз матеріалів "Замовника" і є його власністю, які підлягають поверненню назад i 3 швейним виробом.

ТзДВ "Трембіта", як "Виконавець", бере на себе зобов'язання по виготовленню швейних виробів 
Белінський П. І., Загриновський М.В., Рубенок Т. М.

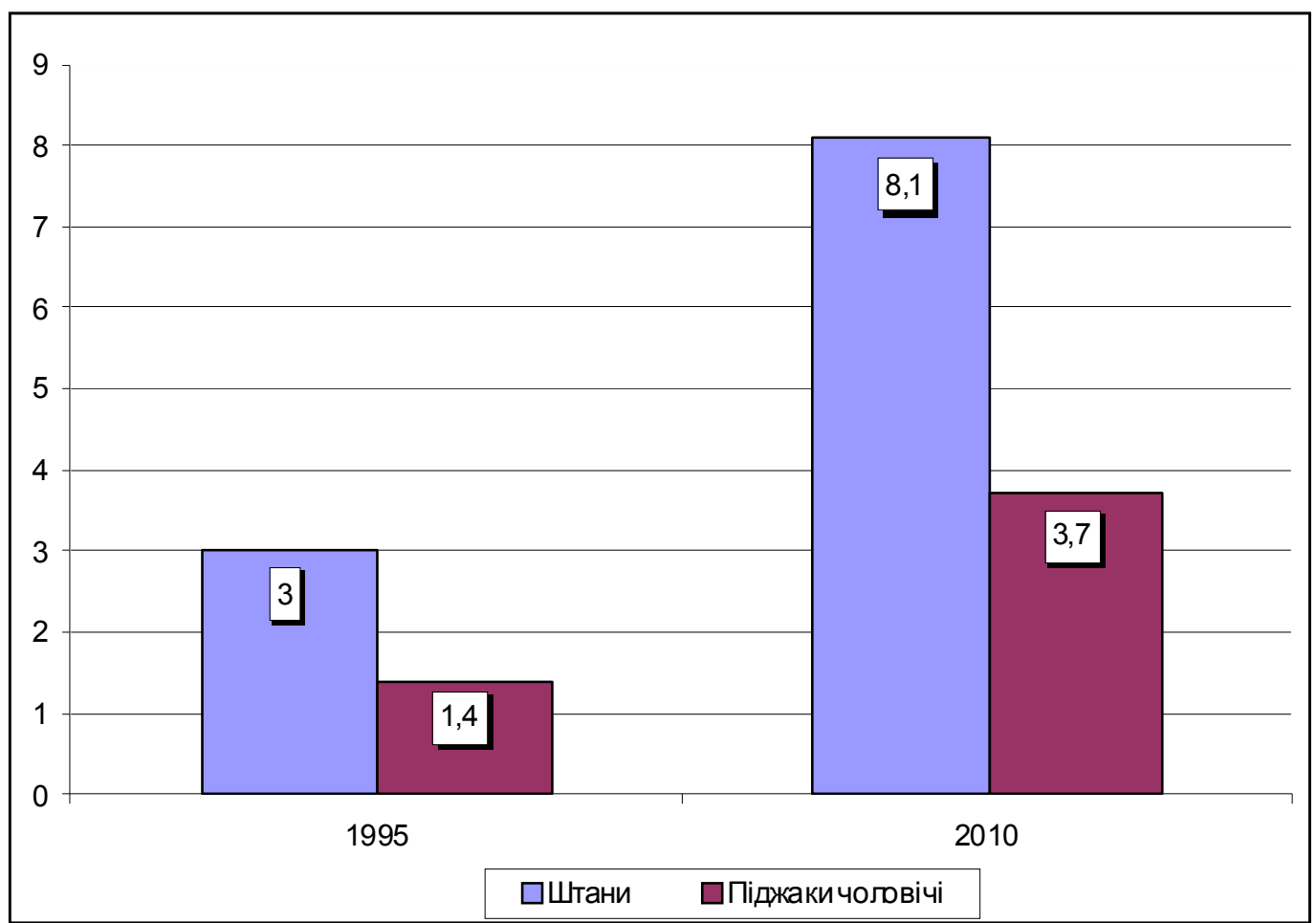

Рис. 1. Збільшення виробництва швейних виробів (чоловічих піджаків і штанів) за робочу зміну, одиниць

відповідної якості та відвантаження замовлення, як це обумовлено в додатках до контракту.

"Замовник" проводить оплату "Виконавцю" за обсяг виконаних послуг, тобто пошив кожної одиниці виробу. Загальна вартість виробу, в тому числі послуг за його пошиття, наведено а таблиці 5.

\section{Динаміка вартості послуг пошиття, давальницької сировини й одного чоловічого костюма (в свро)}

\begin{tabular}{|c|c|c|c|c|c|c|}
\hline \multirow{2}{*}{$\begin{array}{l}\text { Наз ва } \\
\text { в иробу }\end{array}$} & \multirow{2}{*}{$\begin{array}{c}\text { К-ть } \\
\text { замовлень }\end{array}$} & \multicolumn{5}{|c|}{ Вартість } \\
\hline & & $\begin{array}{c}\text { Послуг } \\
\text { пошиття } \\
\text { костюма }\end{array}$ & $\begin{array}{c}\text { Сума } \\
\text { послуг }\end{array}$ & $\begin{array}{c}\text { Давальницької } \\
\text { сиров ини }\end{array}$ & $\begin{array}{l}\text { Загальна } \\
\text { вартість }\end{array}$ & $\begin{array}{c}\text { Одного } \\
\text { костюма }\end{array}$ \\
\hline \multicolumn{7}{|c|}{2007 рік (контракт від 27.01.07.) } \\
\hline $\begin{array}{c}\text { Костюм } \\
\text { чоловічий }\end{array}$ & 297 & 11,95 & 3549,15 & 8083,79 & 11632,94 & 39,1 \\
\hline \multicolumn{7}{|c|}{2009 рік (контракт від 03.12.09.) } \\
\hline $\begin{array}{c}\text { Костюм } \\
\text { чоловічий }\end{array}$ & 463 & 12,60 & 5833,80 & 12207,14 & 18040,94 & 38,9 \\
\hline \multicolumn{7}{|c|}{2010 рік (контракт від 24.04.10.) } \\
\hline $\begin{array}{c}\text { Костюм } \\
\text { чоловічий }\end{array}$ & 1900 & 13,41 & 254779,00 & 35059 & 60538,60 & 31,8 \\
\hline
\end{tabular}

3 даних, наведених у таблиці, видно, що 3 кожним контрактом у наступні роки відбулися зміни в обсязі замовлень та вартості послуг за пошиття одиниці виробу. Це залежить від вартості сировини й узгодженості сторін, при укладенні контракту. Згідно 3 домовленістю, поставка сировини, умови іiі переробки визначаються кожним контрактом. Вартість послуг у структурі вартості одного виробу залежно від цінності сировини коливається в межах 30,5-42 відсотка 7. с. 5-7. Навіть в останні роки, коли згідно 3 замовленнями постачальників давальницької сировини, виготовлялось щорічно 140-150 тисяч чоловічих костюмів, а в касу підприємства 
надходило 1,8-2,0 мільйони євро, або 18-20 млн.грн., виробничі потужності дозволяють подвоїти обсяг виробництва. Для цього бракує лише сталого попиту на швейні вироби підприємства, яке має високий імідж як на внутрішньому, так і на зовнішньому ринках.

Висновки. Переробка давальницької сировини позитивно впливає на платіжний баланс підприємства-переробника давальницької сировини, оскільки це позначається на зменшенні інвестиційної та валютної нестачі.

Давальницькі схеми переробки сировини сприяють зайнятості більш ніж тисячного колективу підприємства та завантаженню виробничих потужностей.

Робота 3 давальницькою сировиною дозволяє підприємствам-переробникам вступати в економічні зв'язки не лише 3 підприємствами замовниками, але й 3 іншими структурами, оскільки не всі товарні потоки виходять від замовника та закінчуються на ньому, а існує велика відмітність між місцем купівлі сировини та збутом продукції. 5. с. 512-520 .

\section{Список літератури}

1. Закон України " Про операції з давальницькою сировиною у зовнішньоекономічних відносинах" (Відомості Верховної Ради України № 328/95 - ВР від 15.09.95 1995, №32)
2. Авдашева С. Давальчество в российской промышленности: причины и результаты использования // Вопросы экономики. - 2001.-№6. - C.100-113.

3. Нижній І. Нове в операціях з давальницькою сировиною // Діловий вісник. - 2001. - №3(82). - С. 21-23.

4. Житный В.Е. Особенности экономического анализа операций с давальческим сырьем // Маркетинг: теория и практика: Зб.наук.праць Східноукраїнського державного університету. Вип. 4. - Луганськ: СУДУ, 2000. - С.64-72.

5. Пісьмаченко Л. Державний контроль за операціями 3 давальницькою сировиною та основні напрями удосконалення: Зб.наук.праць НАДУ при Президентові України /За заг.ред. В.І.Лугового, В.М. Князєва. - К.: Вид-во НАДУ, 2005. - Вип.2. - С. 512-520.

6. Чорнокондратенко С. Переробка товарів на митній території України // Митниця., 2004. № 3. С.24-25.

7. Чудина С. Давальческие операции: преимущества и риски // Митниця., 2004. - №1 . C. 5-7.

8. Гребельник О.П. Основи зовнішньоекономічної діяльності. - К.: Центр навчальної літератури, 2004. - 384 с.

9. Дроздова Г.M. Менеджмент зовнішньоекономічної діяльності підприємства. К.: ЦУЛ, 2002. - 172 с.

\section{Аннотация \\ Петро Белинский, Михаил Загриновский, Татьяна Рубенок \\ ЭФФЕКТИВНОСТЬ РАБОТЫ ПРЕДПРИЯТИЯ НА ДАВАЛЬЧЕСКОМ СЕРЬЕ И ФИНАНСОВО-ЕКОНОМИЧЕСКАЯ БЕЗОПАСНОСТЬ ЕГО ДЕЯТЕЛЬНОСТИ}

Анализируются проблемь деятельности предприятия, работающего на давальческом сырье, его взаимосвязи в системе международных коммерческих прочессов и определяется механизм формирования финансово-экономической безопасности фирмы.

Ключевые слова: давальческое сырье, кооперация, техническое переоснащение, конкурентоспособность, производительность, эффективность.

\section{Summary}

Petro Belins' kuy, Mikhail Sagrynovs' kuy, Tetyana Rubenok

\section{ENTEKPKISE EFFICACY ON RAW MATEKIALS SUPPLIED BY CUSTOMER AND FINANCIAL AND EKONOMIK SECUKITY OF ITS AKTIVITIES}

The article is devoted to the problem of researching the place of operations with goods made on commission in the system of the international commercial operations it shonld fe notul commission in the system of international commercial operations and the plant mechanism of molding has been fixed.

Key words: folling new, cooperation, technical upgrade, competitiveness, productivity, efficiency. 


\section{СШпак Л.I., 2011 \\ Кам'янець-Подільський національний університет імені Івана Огієнка, м. Кам'янець-Подільськ}

\section{ЗАРУБІЖНИЙ ТА ВІТЧИЗНЯНИЙ ДОСВІД РОЗВИТКУ І ФУНКЦІОНУВАННЯ ПІДПРИЄМСТВ МАЛОГО БІЗНЕСУ В КОНТЕКСТІ ОНОВЛЕННЯ УКРАЇНСЬКОЇ ЕКОНОМІКИ}

Головним напрямком політики ринкової трансформащії економіки України є створення умов становлення та розвитку національного підприємства, у першу чергу малого і середнього бізнесу. Його місие і роль у структурі ринкової економіки визначаються тим, щзо ией бізнес становить основу дрібного виробництва, здатний динамічно забезпечувати нові ринкові потреби, а також створювати нові робочі місия.

Основна значимість малих підприємств у сприянні соџіальному та регіональному розвитку в країні.

Ключові слова: малий бізнес, економічні відносини, інноваційний потенціал, підприємництво.

Становлення та розвиток малого бізнесу як найбільш динамічного елементу, структури національного господарства - стратегічна проблема економічної політики в умовах формування соціально-зорієнтованого ринку.

Перехід до ринку потребує формування відкритої для зовнішнього світу господарської системи. Для досягнення цієї мети необхідні кардинальні зміни також у сфері зовнішньоекономічної діяльності, спрямоване на інтегрування в світове господарство та розвиток взаємовигідного співробітництва.

Значення ролі і місця підприємницької діяльності привертало постійну увагу законодавців та науковців. Проблемам малого бізнесу присвятили свої роботи 3.С Варналій, М.Й Малік, Ю.О.Клочко, Г.М.Білоус С.В.Мочерний, І.П.Булєєв, В.М.Ляшенко, Г.В.Козаченко, Л.І.Воротіна, О.Є.Кузьмін, В.Савченко, В.В.Хахулін, О.З.Денега, О.Г.Кошелєва, А.М.Хімченко тощо. Особлива увага дослідників приділяється вивченню ролі малого підприємництва у формуванні економічних відносин і систематизації поглядів на природу підприємництва в історичному аспекті

Мета статті - дослідження ролі малого бізнесу в умовах дестабілізації економіки. Відповідно, необхідно виділити ті ознаки даних суб єктів підприємництва, які дозволяють їм найефективніше стимулювати розвиток товарних ринків, зокрема конкуренції, не потребуючи при цьому великих інвестиційних вкладень.

Україна, ставши на шлях незалежного розвитку, переслідує цілі щодо розбудови незалежної держави і формування та розвиток соціальноекономічної системи на засадах ринку.
Але, незважаючи на це, на сьогодні залишається нез'ясованим питання формування "необмеженої" кількості учасників господарської діяльності, що $є$ чи не найголовнішою й обов'язковою умовою сучасного соціальноорієнтованого ринкового господарства. Іншими словами, майже відсутній той прошарок суспільства, який складають малі та середні підприємці.

Малий бізнес - це провідний сектор економіки. Він складає основу дрібнотоварного виробництва; визначає темпи економічного росту, структуру та якісну характеристику внутрішнього валового продукту, ступінь демократизації суспільства; здійснює структурну перебудову економіки, швидку окупність витрат, свободу ринкового вибору; забезпечує насичення ринку товарами та послугами, реалізацію інновацій, додаткові робочі місця; характеризується високою мобільністю, раціональними формами управління; формує соціальний прошарок підприємців-власників, основу середнього класу; сприяє послабленню монополізму, розвитку конкуренції.

Малий та середній бізнес відіграє важливу роль в економічному житті майже в усіх країнах світу від високо розвинутих до країн, що розвиваються.

Основним завданням української економіки $\epsilon$ реалізація нових елементів господарського механізму та вдосконалення організаційної структури управління народним господарством. А це "безпосередньо пов'язано $з$ дослідженням нових тенденцій концентрації, спеціалізації та комбінування виробництва" [1]. Гігантоманія у виробництві, що була притаманна соціалістичному етапу розвитку, привела до того, що великі i надпотужні підприємства стали домінантою у 

БЗЗНЕСУ В КОНТЕКСТІ ОНОВЛЕННЯ УКРАЇНСЬКОЇ ЕКОНОМІКИ

вітчизняній економіці. Це одна 3 причин, що, незважаючи на існуванні антимонопольного законодавства, до цього часу не створено умов дій конкуренції та економічного змагання між господарюючими суб'єктами. Тому заслуговує на увагу досвід розвинених країн, в основі якого тенденція прямування шляхом створення умов для розвитку підприємництва.

Необхідно визнати, що у багатьох випадках дрібне виробництво ефективніше від великого, що курс на поєднання підприємств різних розмірів $є$ найбільш правильний для поліпшення пристосованості до сучасних вимог господарювання, а також прискорення науковотехнічного прогресу по цілому ряду напрямків. Не менш важливе і питання розподілу господарських функцій між великими, середніми та дрібними підприємствами та створення комплексу умов, за яких невеликі підприємства будуть працювати ефективніше та 3 максимальною віддачею для народного господарства [1]. У цій частині важливим є розв'язання двох проблем:

- створення умов за рахунок вдосконалення організаційного механізму по введенню підприємництва в систему суспільного виробництва для більш ефективного їх функціонування;

- розвиток коопераційних зв'язків між великими та середнім і дрібними підприємствами.

Незважаючи на те, що гігантські корпорації, наприклад у США, відіграють провідну роль в економіці країни і визначають напрямки економічної політики, одночасно активізується мале та середнє підприємництво. Якщо сторіччя тому у США нараховувалось 300 тис. дрібних фірм, то в середині 60-х років ХХ ст. їх було вже 5 млн., а на початку XXI століття - 18,5 млн. одиниць [2].

Зрештою, до малого і середнього бізнесу ставлення неоднозначне. Протягом багатьох років вважали, що малий та середній бізнес - це анахронізм, усього лиш пережиток минулого [3]. Але його розвиток сприяє швидким темпам впровадження нововведень і технологічних змін, швидкому насиченню ринку товарами та послугами, появі та впровадженню великої кількості винаходів і рацпропозицій, подоланню галузевого та регіонального монополізму в економіці, розширенню конкуренції за споживача, що приводить до надання їм продукції та послуг достатньо високої якості при помірних цінах, підвищенню зайнятості населення, підвищенню експортного потенціалу, можливості отримання великих сум податкових надходжень, зміцненню суспільно-політичної та економічної стійкості в державі.

Але на даний час, як зазначає Варналій 3.С., малий бізнес в Україні має певні риси, які суттєво відрізняють його від підприємництва більшості зарубіжних країн, а саме: низький рівень технічної озброєності при значному інноваційному потенціалі; низький управлінський рівень, бракує знань, досвіду та культури ринкових відносин; прагнення до максимальної самостійності (більшість зарубіжних малих підприємств працює за умов франчайзингу); поєднання в межах одного малого підприємства декількох видів діяльності, неможливість в більшості випадків орієнтуватися на однопродуктову модель розвитку. [4, с.102]. А вже, до перелічених рис можна додати відсутність системи самоорганізації та недостатня інфраструктура підтримки малого підприємництва; відсутність повної і вірогідної інформації про стан та кон'юнктуру ринку, низький рівень консультаційних послуг та спеціальних освітніх програм; практична відсутність державної фінансово-кредитної підтримки; недовіра західних партнерів та негативне психологічне ставлення населення до підприємців.

Великою мірою роль малого підприємництва полягає у вирішенні питання зайнятості, що проявляється, насамперед, у здатності малого бізнесу створювати нові робочі місця і поглинати надлишкову робочу силу. Адже в той час, коли йде процес скорочення робочих місць на великих підприємствах, малі фірми не тільки зберігають, але й створюють нові робочі місця і поглинають надлишкову робочу силу.

Тому в останні десятиріччя все ширше стала визнаватися роль цього сектора економіки у напрямку створення робочих місць та впровадження бізнесових ідей. Зусилля Європи у сучасній економіці супроводжуються успіхом тільки тоді, коли малий бізнес буде поставлений на перше місце серед новітніх реалій в економіці країни. Нині в Україні зареєстровано 1,7 млн. малих підприємств разом з фізичними особами підприємцями, які забезпечують роботою понад 3,4 млн. чоловік.[5] Протягом 2010 року кількість працюючих малих підприємств в Україні збільшилося на 16,2 тисяч, або на 7,2\% більше, ніж у 2009 році.

Враховуючи світову практику та досвід розвинених країн світу, варто відзначити, що до 10 відсотків малих підприємств виростають у великі компанії. А в Україні спостерігається блокування росту перспективних малих підприємств. Причина цього - низка системних загроз:

- обмеженість фінансових ресурсів;

- відсутність фінансових резервів і загроза швидкого банкрутства;

- низька конкурентоспроможність продукції, виробництво якої зосереджено на економії на 
Шиак Л. I.

масштабах.

Отже, слід зазначити, що однією 3 найвагоміших перепон на шляху діяльності малих підприємств є відсутність фінансових ресурсів для інвестиційного розвитку. В країнах з розвинутою економікою найбільш поширеною формою фінансової підтримки малого бізнесу (70\%) є кредитні ресурси банків. Однак в Україні за умови обмеженості кредитних ресурсів, високих цін на гроші та великого ризику, процентні ставки є надто високими і не можуть бути джерелом інвестицій для малого бізнесу.

Виходячи 3 цього, необхідно розробити нові стратегії, які дали б можливість підприємницьких структур забезпечити більш високий рівень економічного зростання та ефективності. Тому виникає необхідність у дослідженні та виробленні основних умов по стимулюванню розвитку малого та середнього бізнесу, і на цій основі забезпечити максимальну зайнятість населення.

Важливість дослідження проблем розвитку підприємництва полягає в тому, що Україна знаходиться на перехідному етапі свого політичного та економічного розвитку. На сьогодні економіка держави знаходиться в такому стані, для якого характерні такі явища, як загальна криза політичного та економічного життя, недосконалість законодавчих процесів, тінізація економіки, корупція на тлі зубожіння більшості населення, незавершеність процесу приватизації, зневіра народу України в ринкові реформи, послаблення мотивацій до ініціативного підприємництва, наявність перекосів у структурі народного господарства і уповільнення процесів структурної перебудови економіки, високий рівень як явного, так і прихованого безробіття, нерозвиненість ринкової інфраструктури.

Важливість малих підприємств полягає ще й у тому, що, ведучи запеклу конкурентну боротьбу за виживання, вони змушені постійно розвиватися й адаптуватися до поточних умов ринку, адже, щоб існувати, треба діставати кошти для існування, тобто бути кращими за інших, щоб прибуток діставався саме їм. До того ж переслідуючи дані цілі виникають протиріччя, яке утворилося між фінансовим і промисловим капіталом.

Фінансовий капітал домінуючий у сучасній українській економіці і зміцнюється завдяки політиці монетаризму та за рахунок Далекого Сходу. Додатково, що особливо важливо для України, розглянути стан розвитку підприємництва в сусідній $з$ нами країні - Росії. Такий підхід грунтується на тому, що:

1. Означені групи країн високорозвинені, й наша держава орієнтується на них;

2. У цих країнах накопичено спаравді великий досвід діяльності малих і середніх підприємств;

3. Вони представляють усе розмаїття підходів по залученню малого та середнього бізнесу у народне господарство;

4. Росія відносно України у своєму економічному розвитку випереджаючими темпами просувається вперед. Отже, іiі досвід нам буде корисним.

Необхідно враховувати, що економіка розвинутих країн сформувалася на основі дрібних підприємств. Ентузіазм і підприємливість населення $\epsilon$ їх внутрішньою рисою. Тому за таких умов піклування держави зводиться не стільки до сприяння створенню малих підприємств як до обмеження їх "апетитів". Лише після того, як великі підприємства стали притискати дрібні, держава змушена була створити штучні умови для вирівнювання економічної ситуації та формувати рівно вигідне економічне середовище [6, с.69].

До числа найбільш гострих проблем, що торкаються малого та середнього бізнесу, можна віднести:

1) низький рівень кваліфікації управлінського персоналу;

2) фінансово-кредитні;

3) труднощі в реалізації готової продукції;

4) відсутність достатньої кількості інформації з господарських питань [6,с.70].

Аналізуючи зарубіжний та вітчизняний досвід розвитку малого і середнього бізнесу, можна зробити такі висновки:

1. Малий та середній бізнес відіграє значну роль в економічному житті розвинених країн світу. В ньому зайнято: в країнах СС 72\%, у Росії - 10\%. Питома вага малого та середнього бізнесу у валовому внутрішньому продукті складає від 5065\%, а експортної продукції виробляється від 20 до 40\% залежно від країни.

2. Незважаючи на великий внесок в економіку, МСБ потребує державної підтримки до державного регулювання, виходячи з проблем, які перед ним стоять. Політика держави по відношенню до нього в розвинутих країнах - це політика зацікавленості і підтримки на всіх напрямках економічного і політичного життя i визначається державою як пріоритетна. Так, у деяких країнах прийнято низку законів серед яких - Закон про малий бізнес (у США) і акт про основи політики щодо малих і середніх підприємств (в Японіï). Для управління малим бізнесом створюються спеціальні органи, як Адміністрація Малого Бізнесу у США.

3. Досвід розвитку МСП у розвинутих країнах свідчить про те, що основні проблеми полягають у фінансово-кредитній сфері, інформаційному забезпеченні, низькому рівні кваліфікації 
управлінського персоналу, збуті продукції.

4.Основними способами впливу на процес розвитку МСБ є законодавче забезпечення, розробка та впровадження державних програм підтримки по різних напрямках діяльності, державне субсидування та кредитування, створення організаційних структур підтримки.

6.Аналіз якісних показників розвитку підприємництва в Україні, незважаючи на його незначний вплив на економіку в цілому, свідчить, про його спроможність виконувати великі завдання, як на макро-, так і мікрорівнях.

7.Проблеми підприємництва в Україні знаходяться в організаційно-правовій, нормативній та регулюючий площині і завдяки використанню досвіду зарубіжних країн деякі з них можуть бути подолані в найближчій перспективі. В основному проблеми пов'язані 3 фінансуванням, продуктивністю праці, управлінням інформацією, професійною підготовкою, збутом і невідповідним регулюючий середовищем.

8. Мале та середнє підприємництво необхідно розглядати в якості форми організації, яка потребує специфічної політики та інститутів спеціального призначення для задоволення їх потреб. Політичні підходи до малих і середніх фірм повинні враховувати тип даної організації та зважати на такі фактори, як маломасштабність, обмеженість ресурсів, місцевий характер, необхідність у координації дій. Основними способами збільшення числа підприємств в Україні є зважена політика приватизації та демонополізації.

\section{Список літератури}

1. Галица И. Государственное предпринимательство в рыночной экономике. Финансовая Украина. - 2003 - № 46 - с. 4.

2. Жук О. Малий бізнес у світі та в Україні. Економіка України - 2008 - № 7 - с. 33-39.

3. Селезньова А. Практика підприємництва. - Діло - 2004 - c. 9 - № 100 - c.6.

4. Варналій 3.С. Мале підприємництво: основи теорії і практики. - 2-ге вид., випр. і доп. - К.: Знання, KOO, $2003-302 \mathrm{c}$.

5. Державний комітет статистики України / Офіційний сайт www.ukrstat.gov.ua.

6. Абрамов В., Радомисельський М. "Малий бізнес і ринкова конкуренція" // Економіка України - № 11, 1995 - с. 67-71.

7. Муравьев А.И., Игнатьев А.М., Крутик А.Б. Малый бизнес: экономика, организация, финансы. Учебное пособие для вузов. - СПБ.: Издательский дом "Бизнес-пресса", 2006. - 608 с.

\section{Аннотация}

Людмила Шпак

\section{ЗАРУБЕЖНЫЙ И ОТЕЧЕСТВЕННЫЙ ОПЫТ РАЗВИТИЯ И ФУНКЦИОНИРОВАНИЯ ПРЕДПРИЯТИЙ МАЛОГО БИЗНЕСА В КОНТЕКСТЕ ОБНОВЛЕНИЯ УКРАИНСКОЙ ЭКОНОМИКИ}

Главным направлением политики рыночной трансформащии экономики Украины является создание условий становления и развития национального предприятия, в первую очередь малого и среднего бизнеса. Его место и роль в структуре рыночной экономики определяются тем, что этот бизнес составляет основу мелкого производства, способный динамически обеспечивать новые рыночные потребности, а также создавать новые рабочие места. Основная значимость мальх предприятий в содействии социальному и региональному развитию в стране.

Ключевые слова: малый бизнес, экономические отношения, инновационный потенциал, предпринимательство.

Summary

Lydmula Shpak

\section{FOREIGN AND DOMESTIC EXPERIENCE DEVELOPMENT AND OPERATION OF SMALL BUSINESSES IN THE CONTEXT UPDATES UKRAINIAN ECONOMY}

The main policy direction of market transformation of economy of Ukraine is to create conditions for the establishment and development of domestic enterprises, especially small and medium businesses. Its place and role in the structure of the market economy are determined that this business is the basis of small-scale production that can dynamically provide new market needs and create new jobs.

The main significance of small enterprises is in the fostering social and regional development in the country.

Keywords: small business, economic relations, innovative potential, enterprise 


\author{
(C) Кошкаров B.C., 2011 \\ Чернівецький кооперативний економіко-правовий коледж, м. Чернівці
}

\title{
ОПТИМІЗАЦЯ ІНФОРМАЦЙНОГОЗАБЕЗПЕЧЕННЯ ПЕРЕБНОГО ПІДПРИЕМСТВА
}

Принщипи прочесу постачання ресурсів підприємства - своєчасність, оптимальні об'єми, низькі затрати. Досягнення иієї мети можливе за умови застосування сучасних економікоматематичних методів, комп'ютерної техніки, оперативного інформачійного забезпечення.

Ключові слова: запаси, сировина, ціна, об'єм, інформація, облік, контроль, оперативний.

Процеси ринкових перетворень, закономірно вимагають адекватних змін для розв'язання проблем в управлінні та підвищення управлінських можливостей його основних інформаційних систем - обліку і контролю.

На підприємствах, які запроваджують новітні концепції менеджменту (управлінського обліку, контролінгу, процесного управління, збалансованої системи показників тощо), перспективними стають саме оперативні обліково-контрольні системи.

Аналіз сучасних досліджень і публікацій. Вагомий внесок у теоретичну розробку проблем оперативного обліку і контролю зробили М.Т. Білуха, Ф.Ф. Бутинець, Б.І. Валуєв, Ю.А. Верига, 3.В. Гуцайлюк, В.П. Завгородній, Г.Г. Кірейцев, Я.Д. Крупка, В.І. Бачинський, М.С. Пушкар, В.С. Рудницький, В.В. Сопко, Б.Ф. Усач, М.Г. Чумаченко, C.I. Шкарабан та багато інших.

Викладені ними наукові положення й отримані результати є основою подальшого вивчення, систематизації і розробки проблем оперативного обліку і контролю, уточнення та конкретизації їхніх організаційно-методичних аспектів з урахуванням вимог ринкової економіки.

Мета статті. Упровадження сучасних інформаційних систем дозволяє застосовувати технологічно складні методи обліку фактичних витрат: нормативний, процесний, попередільний, позамовний, за центрами відповідальності та центрами затрат. Дані технології дозволяють також максимально автоматизувати в оперативному режимі процеси отримання інформації загальновиробничих витрат і розподілу постійних та змінних витрат з використанням вибраної бази розподілу при їх виникненні.

Своєчасний вплив на рівень витрат на виробництво і формування собівартості продукції можливий при такій організації і методиці обліку, при якій причини змін собівартості, допущення перевитрат і отримання економії розкриваються не лише шляхом подальшого вивчення даних бухгалтерського обліку та звітних калькуляцій, але й під час здійснення виробничого процесу i безпосереднього виконання його операцій (блоку операцій) на основі інформації оперативного обліку та планових завдань (планів, оперативнокалендарних графіків, норм, нормативів, даних попередніх періодів тощо).

Викладення основного матеріалу. В умовах сезонності вирощування, збирання та заготівлі сільськогосподарської продукції на формування витрат і результати діяльності підприємства впливає, насамперед, коливання сезонних ринкових цін на сировину (рис. 1, 2).

Найбільша ціна початку сезону C1 знижується до ціни масового збирання урожаю С2 з піковим моментом С3 та переходить до ціни кінця сезону C4.

Обсяги ринкової пропозиції сировини мають зворотну дію порівняно з ціновим коливанням у межах сезону.

Загальна потреба підприємства у конкретній сировині визначається за такою формулою:

$$
V=\sum_{t=1}^{n} V_{t} * K_{t}
$$

де, $\mathrm{V}$ - використання сировини на добу в межах виробничого річного періоду $\mathrm{n}$ діб;

K - інтегрований коригуючий коефіцієнт впливу різних факторів (портфелю замовлень, втрат, комерційного ризику тощо).

Повне використання можливостей економії коштів за рахунок заготівлі всієї сировини у піковий період зростання обсягів пропозицій при зниженні ціни обмежується двома основними факторами (рис. 3): перший - пропускна спроможність устаткування підприємства 3 приймання та первинної обробки сировини, що дорівнює обсягам переробки згідно 3 паспортними даними устаткування мінус обсяг необробленої сировини через втрати часу із-за непередбачених простоїв за різними суб'єктивними та локально об'єктивними причинами; другий - недостатня 


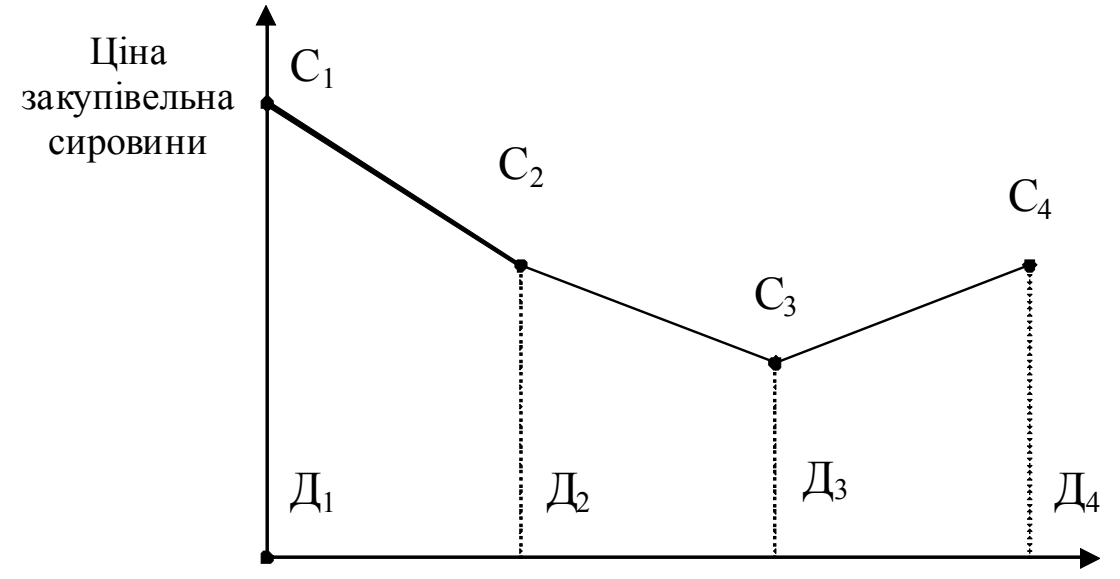

Дні сезону дозрівання урожаю

Рис. 1. Сезонні коливання ціни на сировину

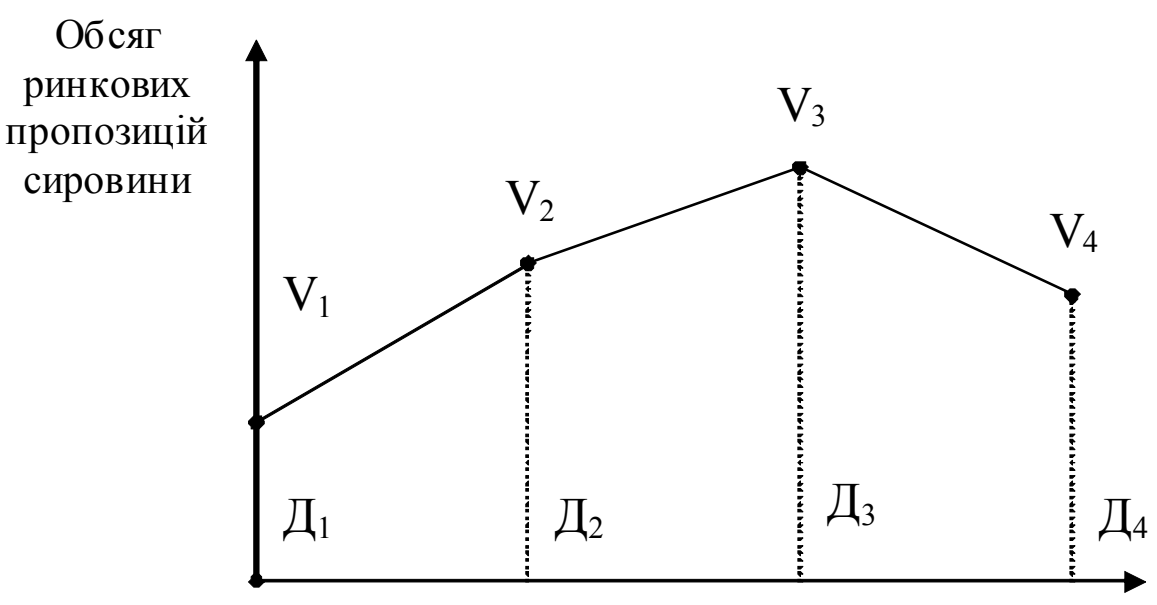

Дні сезону дозрівання урожаю

Рис. 2. Графік коливання пропозицій ринку сировини протягом сезону

налагодженість і взаємодія підрозділів приймання сировини, що призводить до затримок підприємства при виконанні всіх операцій 3 при узгодженні робіт підрозділів.

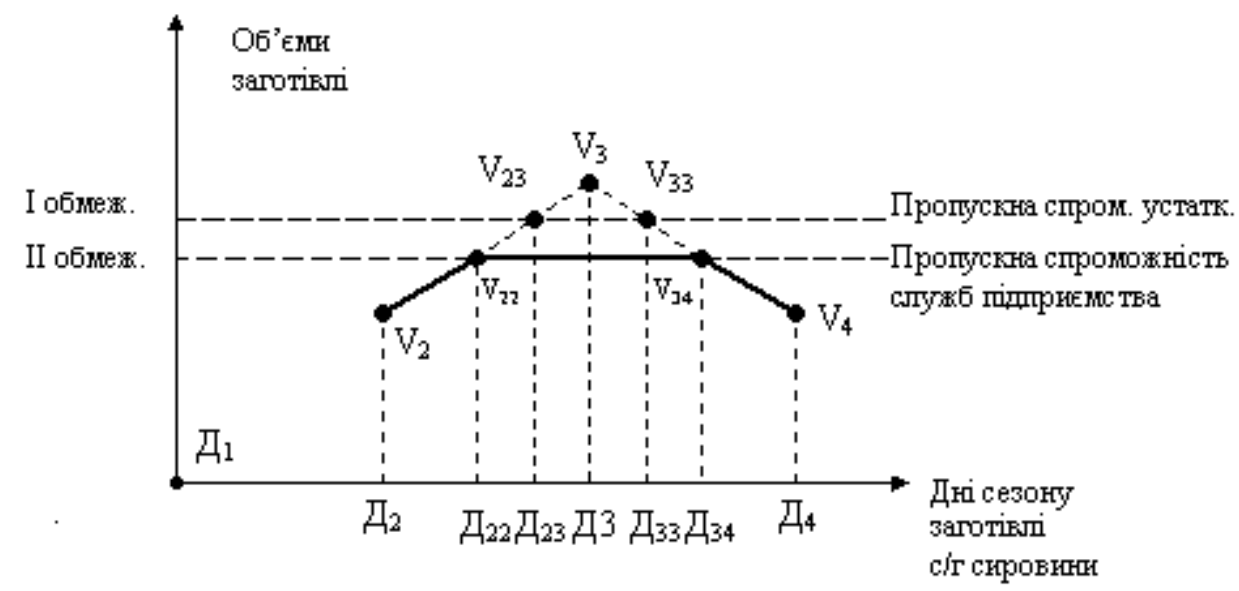

Рис. 3. Вплив обмежуючих факторів на обсяги заготівель і вартість 
Кочкаров В. С.

Економія від послаблення обмежень другого порядку має вираз:

$$
E_{2}=\int_{\bar{A}_{22}}^{\bar{Z}_{34}}\left(V_{\delta}-V_{\delta 22}\right) d t, \quad \text { nрu } V_{\partial} \leq V_{\partial 23}
$$

де С - ціна у дні заготівлі; Vд - обсяг заготівель за добу у день заготівлі.

Економія від послаблення обмежень першого порядку має подібний вираз, але зі своїми параметрами:

$$
E_{1}=\int_{A_{23}}^{д_{33}}\left(V_{\delta}-V_{\delta 23}\right) d t, \quad \text { nрu } V_{\partial 3}>V_{\partial}>V_{\partial 23}
$$

де С $\partial$ - ціна у дні заготівлі; Vд - обсяг заготівель за добу у день заготівлі.
Збільшення обсягу заготівлі сировини за рахунок зняття або послаблення обмежень повинно скорочувати період заготівлі при збереженні показника обсягу необхідної сировини (V) у формулі (1). У такому разі економія підприємства має перевищувати витрати на зберігання сировини на складі (Р) за період від Д34 до Д4, що можна визначити за формулою (4):

$$
E_{1,2}>\int_{Д_{34}}^{д_{4}} V\left(P_{4}-P_{34}\right) d t
$$

де $\mathrm{P}$ - витрати на зберігання сировини на складі; Vд - обсяг заготівель за добу в день заготівлі.

Графічне зображення зміни вартості одиниці сировини у період заготівлі та зберігання на складі подано на рис. 4.

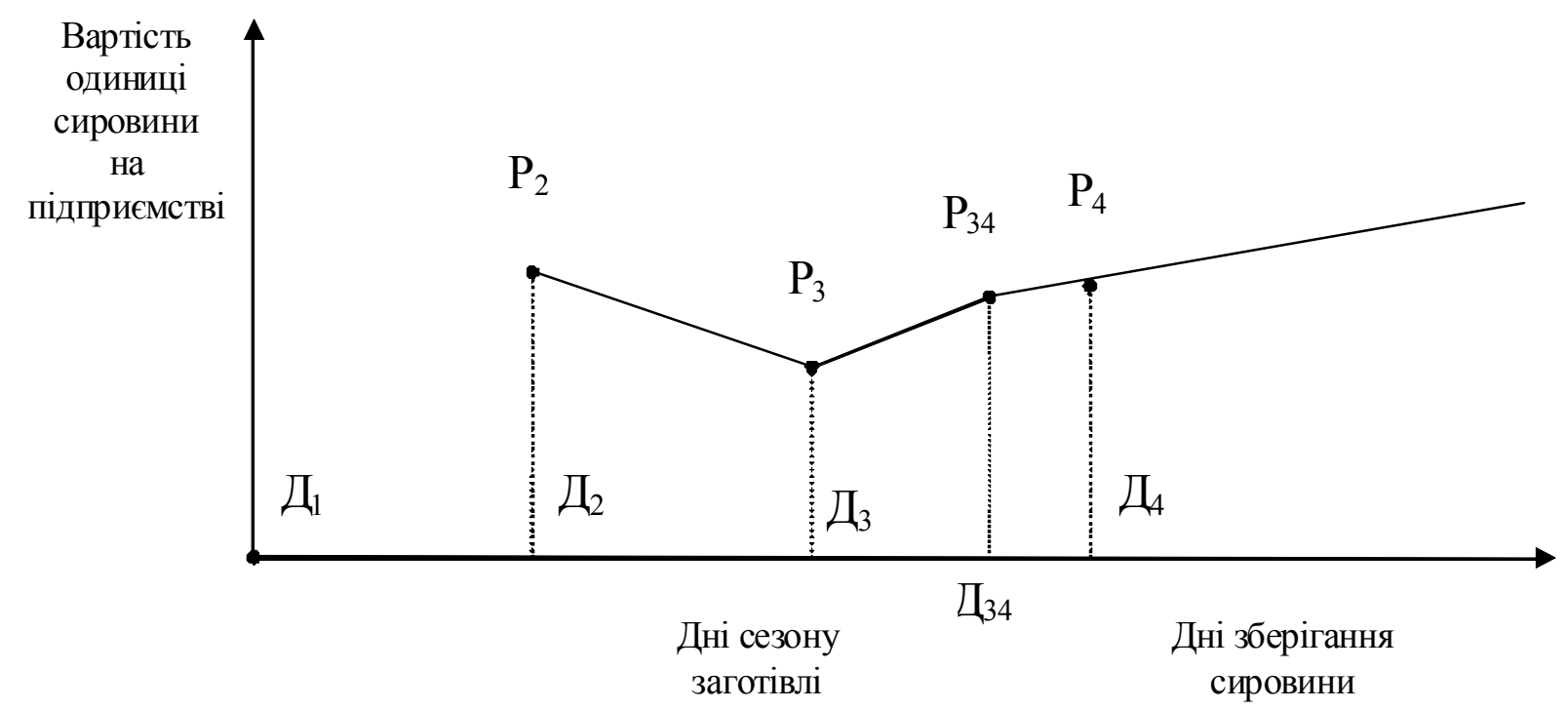

\section{Рис. 4. Зміна вартості одиниці сировини у період заготівлі та зберігання}

Розглядаючи можливості оперативного обліку та контролю щодо сприяння досягненню економії витрат E1 та Е2, логічно зробити висновок, що ці можливості використовуються і на етапах виробництва продукції та іiі реалізації. У такому разі можливий позитивний ланцюговий ефект, що призведе до збільшення обсягів сировини V, необхідної для заготівлі, i, відповідно, зміни всіх параметрів роботи підприємства та їі результатів.

Ми пропонуємо цільову побудову процесів консервного виробництва, зорієнтованих на менеджмент підприємства для досягнення визначеної мети для конкретного процесу, так i виробництва у цілому. Цільове групування завдань ліквідує також управлінські бар'єри між підрозділами: інформаційні, психологічні, суб'єктивні. Навпаки, кожен підрозділ додає власні позитивні результати у спільне виконання процесу; підрозділи тільки формально існують як колектив певних спеціалістів. Реально ж спеціалісти з різних підрозділів об'єднуються у цільові творчі колективи задля виконання окремих задач спільної мети процесу. Виробництво стає гнучким, оперативним, комунікабельним, 3 усвідомленням виконавцями проміжної і кінцевої мети і реагуванням на нестабільність ситуації у конкурентному середовищі та враховує сучасні вимоги ринку.

Ефективне функціонування такого підходу можливе при використанні сучасних інформаційних аналітичних інтерактивних комп'ютеризованих однорангових технологій.

У консервному виробництві при здійсненні процесу постачання виробничих ресурсів доцільно виділити окремі інформаційні блоки оперативного управлінського обліку та контролю за такими стадіями управління:

1) підготовка до забезпечення підприємства сировиною;

2) підготовка до надходження сировини на 
підприємство;

3) надходження та приймання сировини на підприємство;
4) оприбуткування сировини;

5) зберігання сировини.

\section{Табличя 1}

Формування первісної вартості сировини за даними управлінського обліку операцій стадії заготівлі та зберігання сировини

\begin{tabular}{|c|c|c|c|c|}
\hline $\begin{array}{c}\text { Функціональні } \\
\text { витрати }\end{array}$ & $\begin{array}{c}\text { Об'скт обліку } \\
\text { витрат }\end{array}$ & $\begin{array}{c}\text { Концентратор } \\
\text { інформації }\end{array}$ & Вид інформації & $\begin{array}{c}\text { Користувачі } \\
\text { інформації }\end{array}$ \\
\hline \multirow{3}{*}{$\begin{array}{c}\text { Витрати на } \\
\text { підготовку } \\
\text { договорів, графіків } \\
\text { та бази даних }\end{array}$} & \multirow{3}{*}{ Відділ постачання } & \multirow{3}{*}{ Бухгалтерія } & Оперативна & $\begin{array}{c}\text { Керівник } \\
\text { підприємства }\end{array}$ \\
\hline & & & \multirow[b]{2}{*}{ Бухгалтерська } & Плановий відділ \\
\hline & & & & $\begin{array}{c}\text { Юридичний } \\
\text { відділ }\end{array}$ \\
\hline \multirow[t]{2}{*}{$\begin{array}{c}\text { Витрати на роботу } \\
\text { вагової }\end{array}$} & \multirow[t]{2}{*}{ Вагова } & \multirow[t]{2}{*}{ Бухгалтерія } & Оперативна & $\begin{array}{c}\text { Керів ник } \\
\text { підприємства }\end{array}$ \\
\hline & & & Бухгалтерська & Плановий відділ \\
\hline \multirow[t]{2}{*}{$\begin{array}{c}\text { Витрати на роботу } \\
\text { лабораторії }\end{array}$} & \multirow{2}{*}{ Лабораторія } & \multirow{2}{*}{ Бухгалтерія } & Оперативна & $\begin{array}{c}\text { Керівник } \\
\text { підприємства }\end{array}$ \\
\hline & & & Бухгалтерська & Плановий відділ \\
\hline \multirow{2}{*}{$\begin{array}{c}\text { Витрати на роботу } \\
\text { транспорту }\end{array}$} & \multirow{2}{*}{$\begin{array}{c}\text { Транспортний } \\
\text { відділ }\end{array}$} & \multirow{2}{*}{ Бухгалтерія } & Оперативна & $\begin{array}{c}\text { Керівник } \\
\text { підприємства }\end{array}$ \\
\hline & & & Бухгалтерська & Плановий відділ \\
\hline \multirow[t]{2}{*}{$\begin{array}{c}\text { Витрати на роботу } 3 \\
\text { тарою }\end{array}$} & \multirow[t]{2}{*}{ Тарний склад } & \multirow[t]{2}{*}{ Бухгалтерія } & Оперативна & $\begin{array}{c}\text { Керівник } \\
\text { підприємств } \\
\end{array}$ \\
\hline & & & Бухгалтерська & Плановий відділ \\
\hline \multirow{2}{*}{$\begin{array}{c}\text { Витрати на } \\
\text { підготовку } \\
\text { сировини до } \\
\text { зберігання }\end{array}$} & Бункерна & \multirow[b]{2}{*}{ Бухгалтерія } & Оперативна & $\begin{array}{c}\text { Керівник } \\
\text { підприємства } \\
\end{array}$ \\
\hline & Склад сировини & & Бухгалтерська & Плановий відділ \\
\hline \multirow{2}{*}{$\begin{array}{c}\text { Витрати на } \\
\text { зберігання сировини }\end{array}$} & \multirow[t]{2}{*}{ Склад сировини } & \multirow[t]{2}{*}{ Бухгалтерія } & Оперативна & $\begin{array}{c}\text { Керівник } \\
\text { підприємства } \\
\end{array}$ \\
\hline & & & Бухгалтерська & Плановий відділ \\
\hline
\end{tabular}

Таблиия 2

Формування первісної вартості сировини за роботами (блоками) за даними оперативного обліку операцій стадії заготівлі та зберігання сировини

\begin{tabular}{|c|c|c|c|c|}
\hline Процеси (блоки) & $\begin{array}{c}\text { Джерел а } \\
\text { інформа ції }\end{array}$ & $\begin{array}{c}\text { Концентратор } \\
\text { інформаціï }\end{array}$ & Вид інформ ації & $\begin{array}{c}\text { Користувачі } \\
\text { інформ ації }\end{array}$ \\
\hline \multirow{3}{*}{$\begin{array}{c}\text { Витрати на підготовку до } \\
\text { забезпечення та } \\
\text { поступлення сировини на } \\
\text { підприємство }\end{array}$} & \multirow{3}{*}{ Відділ постачання } & \multirow{3}{*}{ Бухгалтерія } & Бухгалтерська & $\begin{array}{c}\text { Керівник } \\
\text { підприємства }\end{array}$ \\
\hline & & & \multirow[b]{2}{*}{ Бухгалтерська } & Планови й відділ \\
\hline & & & & $\begin{array}{c}\text { Юридични й } \\
\text { відділ }\end{array}$ \\
\hline \multirow{3}{*}{$\begin{array}{c}\text { Витрати на поступлення та } \\
\text { приймання сировин и }\end{array}$} & Лабораторія & \multirow{3}{*}{ Бухгалтерія } & Бухгалтерська & $\begin{array}{c}\text { Керівник } \\
\text { підприємства }\end{array}$ \\
\hline & В аго ва & & & \\
\hline & $\begin{array}{c}\text { Транспортний } \\
\text { в ідділ }\end{array}$ & & Бухгалтерська & Планови й відділ \\
\hline \multirow{2}{*}{$\begin{array}{c}\text { Витрати на оприбуткування } \\
\text { сировини для зберігання }\end{array}$} & Склад сировини; & \multirow{2}{*}{ Бухгалтерія } & Бухгалтерська & $\begin{array}{c}\text { Керівник } \\
\text { підприємства }\end{array}$ \\
\hline & $\begin{array}{c}\text { Відділ головного } \\
\text { iнженера }\end{array}$ & & Бухгалтерська & Планови й відділ \\
\hline \multirow{2}{*}{$\begin{array}{c}\text { Витрати на зберігання } \\
\text { сировини }\end{array}$} & \multirow{2}{*}{ Склад сиров ини } & \multirow{2}{*}{ Бухгалтерія } & Бухгалтерська & $\begin{array}{c}\text { Керівник } \\
\text { підприємства }\end{array}$ \\
\hline & & & Бухгалтерська & Планови й відділ \\
\hline
\end{tabular}


Кочкаров В. С.

На основі викладеного матеріалу бачимо, що етап заготівлі та зберігання сировини потребує власної схеми побудови інформаційних центрів, центрів затрат та відповідальності у єдиному комплексі виробництва із застосуванням сучасних інформаційних аналітичних технологій та комбінованого процесного підходу (табл. 3).

Формування центрів відповідальності та центрів витрат

Таблиияя 3 та інформаційних центрів на стадії заготівлі та зберігання сировини

\begin{tabular}{|c|c|c|c|c|c|c|}
\hline \multirow{2}{*}{$\begin{array}{c}\text { Блоки (процеси) та } \\
\text { підрозділи стадії }\end{array}$} & \multicolumn{2}{|c|}{ Інформація обліку } & \multicolumn{2}{|c|}{ Центри } & \multirow{2}{*}{$\begin{array}{l}\text { Оперативний } \\
\text { контроль }\end{array}$} & \multirow{2}{*}{$\begin{array}{c}\text { Потреба у } \\
\text { персональному } \\
\text { комп'ютері }\end{array}$} \\
\hline & $\begin{array}{c}\text { операти- } \\
\text { вного } \\
\end{array}$ & $\begin{array}{c}\text { бухгал- } \\
\text { терського }\end{array}$ & затрат & $\begin{array}{c}\text { відпові- } \\
\text { дальності }\end{array}$ & & \\
\hline $\begin{array}{c}\text { Підготовча робота } 3 \\
\text { постачальникам и: } \\
\text { відділ постачання }\end{array}$ & + & - & + & $\begin{array}{l}+ \\
+ \\
+\end{array}$ & $\begin{array}{l}+ \\
+ \\
\end{array}$ & $\begin{array}{l}- \\
+ \\
\end{array}$ \\
\hline $\begin{array}{l}\text { Приймання } \\
\text { сировини: } \\
\text { - лабораторія; } \\
\text { - центральна вагова; } \\
\text { розвантажування та } \\
\text { замороження }\end{array}$ & $\begin{array}{l}+ \\
+ \\
+ \\
+\end{array}$ & $\begin{array}{l}+ \\
- \\
+ \\
-\end{array}$ & $\begin{array}{l}+ \\
+ \\
+ \\
+\end{array}$ & $\begin{array}{l}+ \\
+ \\
+ \\
+\end{array}$ & $\begin{array}{l}+ \\
+ \\
+ \\
+\end{array}$ & $\begin{array}{l}+ \\
+ \\
-\end{array}$ \\
\hline $\begin{array}{c}\text { Зберігання } \\
\text { сировини: } \\
\text { - склад сировини }\end{array}$ & $\begin{array}{l}+ \\
+\end{array}$ & $\begin{array}{l}+ \\
+\end{array}$ & $\begin{array}{l}+ \\
+\end{array}$ & $\begin{array}{l}+ \\
+\end{array}$ & $\begin{array}{l}+ \\
+\end{array}$ & $\begin{array}{l}+ \\
+\end{array}$ \\
\hline $\begin{array}{l}\text { Допоміжні операції: } \\
\text { - тарний склад } \\
\text { - транспортний } \\
\text { відділ }\end{array}$ & $\begin{array}{l}+ \\
+ \\
+\end{array}$ & $\begin{array}{l}+ \\
+ \\
+\end{array}$ & $\begin{array}{l}+ \\
+ \\
+\end{array}$ & $\begin{array}{l}+ \\
+ \\
+\end{array}$ & $\begin{array}{l}+ \\
+ \\
+\end{array}$ & $\begin{array}{l}+ \\
+\end{array}$ \\
\hline $\begin{array}{l}\text { Міжпідроздільне } \\
\text { перебування } \\
\text { сировини }\end{array}$ & + & - & - & - & + & - \\
\hline
\end{tabular}

Отже, із сучасних концепцій менеджменту 3 погляду предмету й методу дослідження особливе місце відведено концепції процесного управління, яка у повній мірі відповідає особливостям діяльності консервних підприємств i спрямована на її комплексне покращання. Процесний підхід до побудови інформаційної системи та управління може застосовуватись при лінійних, функціональних чи комбінованих організаційно-технологічних структурах, вибір яких залежить від рівня розвитку менеджменту підприємства в умовах конкуренції та масовості випуску аналогічної продукції. Оперативний управлінський облік на консервних підприємствах доцільно організовувати 3 урахуванням переваг процесного підходу до управління з поділом виділених процесів на блоки та операції для їх оптимізації з метою мінімізації витрат і максимізації доходів.

\section{Список літератури}

1. Бачинський В.І. Облік і контроль виробничих витрат у системі управління підприємством: автореферат канд. екон. наук: 08.06.04.- Львів, 1998. $19 \mathrm{c}$.

2. Мізюк Б.М. Стратегічне управління підприємством. - Львів: "Коопосвіта" ЛКА., 1999. $388 \mathrm{c}$.

3. Попович П. Я. Економічний аналіз діяльності суб'єктів господарювання. Підручник. - Тернопіль: Економічна думка. - 2001. - 365 с. 


\section{Аннотация}

Владимир Кочкаров

\section{ОПТИМИЗАЦИЯ ИНФОРМАЦИОННОГО ОБЕСПЕЧЕНИЯ ПЕРЕРАБАТЫВАЮЩЕГО ПРЕДПРИЯТИЯ}

Принциипы процесса поставки ресурсов предприятия - своевременность, оптимальные объемы, низкие затраты. Достижение этой цели возможно при условии применения современных экономико-математических методов, компьютерной техники, оперативного информационного обеспечения.

Ключевые слова: запасы, сырье, цчена, объем, информацчия, учет, контроль, оперативный.

\section{Annotation}

Volodymyr Koshkarov

\section{THE INFORMATION MAINTENANCE OPTIMIZATION OF THE INDUSTRIAL ENTERPRISE}

The main principles of resource delivery process - timeliness, optimum volumes, low expenses. Achievement of this purpose is possible with application of modern economic-mathematical methods, the computer technics and operative information support.

Key words: economy, modeling, production, accounting, information, resources, expenses, reserve. 
УДК 338. 439:332.368

(C) Збродська О. В., 2011

Чернівецький національний університет імені Юрія Федьковича, м. Чернівці

\section{ЧИННИКИ ВИКОРИСТАННЯ РЕСУРСНОГО ПОТЕНЦАЛУ СІЛЬСЬКОГОСПОДАРСЬКИХ ПІДПРИЄМСТВ НА РАДІАЦЙНО ЗАБРУДНЕНИХ ТЕРИТОРІЯХ}

Розглянено основні чинники використання ресурсного потенціалу на радіаційно забруднених територіях. Встановили перелік внутрішніх та зовнішніх чинників, які визначають ефективність використання ресурсного потенціалу, а також оцінили ступінь впливу кожного із виявленних чинників. Досліджено процес функиіонування та розвиток системної і динамічної категорії ресурсний потенціал за допомогою методологічних приниипів синергетики.

Ключові слова: ресурсний потенціал, сільськогосподарське підприємство, принципи синергетики, економічний потенціал, радіаційно забруднені території.

Будь-який процес виробництва потребує залучення і використання певної кількості та певного набору ресурсів. Сільське господарство як галузь виробництва використовує достатньо широкий перелік різноманітних ресурсів, частина 3 яких має природне походження, а частина $\epsilon$ продуктами інших галузей матеріального виробництва. Ліпша забезпеченість тими чи іншими видами ресурсів визначає галузеву спрямованість сільськогосподарського виробництва. У будь-якому випадку ефективність такого виробництва значно визначатиметься здатністю керівництва сільськогосподарського підприємства об'єктивно оцінити та раціонально реалізувати наявний ресурсний потенціал.

Аналіз ефективності використання наявного у підприємства ресурсного потенціалу має на меті встановлення фактичних значень цілого ряду ключових фінансово-економічних показників і порівняння їх 3 плановими показниками та значеннями аналогічних показників еталонного підприємства чи даного суб'єкта господарювання за минулі періоди. Однак констатація факту, що ресурсний потенціал використовувався ефективно чи неефективно, недостатня. Необхідно встановити перелік внугрішніх ізовнішніх чинників, які визначали ефективність використання ресурсного потенціалу, а також, за можливістю, спробувати оцінити ступінь впливу кожного із виявлених чинників.

Розгляд чинників ефективності використання ресурсного потенціалу підприємства знайшов відображення в роботах окремих економістів. Основними з таких чинників Т. Кібук вважає такі: склад та сучасний стан системи наявних ресурсів; ступінь відповідності ресурсного потенціалу стратегічним цілям і завданням підприємства; спроможність ресурсного потенціалу забезпечити стійкість підприємства проти впливу зовнішнього середовища та його внутрішня гнучкість (адаптованість); організаційні та управлінські процеси на підприємстві, які спрямовані на розвиток ключових компетенцій, інтеграцію усіх видів діяльності; конкурентне середовище, особливо ключові компетенції конкурентів та їх ресурси [1]. Поділяючи позицію автора щодо важливості вказаних чинників, водночас вважаємо, що вони більше відносяться до формування умов використання ресурсного потенціалу.

Одним 3 ключових чинників ефективності використання наявного ресурсного потенціалу В. Березін вважає його структуру. Зміна структури, на думку ученого, в свою чергу залежить від низки чинників: розмірів підприємства; різноманітності (диверсифікованості) видів його діяльності; якості кадрового потенціалу; динамізму зовнішнього середовища; географічного розміщення підприємства; ефективності системи менеджменту; рівня технологічного забезпечення виробництва; розвитку стратегічного планування тощо [9]. Вважаємо, що вказаний перелік чинників не враховує ще ряду важливих моментів, зокрема фінансового стану суб'єкта господарювання, рівня цін на різні види ресурсів, амортизаційної політики підприємства тощо.

Для узагальненої кількісної оцінки впливу (сили та характеру) зовнішнього оточення та внутрішнього середовища на структуру потенціалу та стан підприємства В. Березін вважає за доцільне виокремлювати чинники як сприятливого, так і несприятливого впливу [2]. Подібної думки дотримується і О. Шаманська, яка пропонує проводити рейтингову оцінку ресурсів внутрішнього середовища. На іiі думку, узагальнена оцінка, що робиться в результаті підсумовування оцінок факторів сили підприємства 

НА РАДІАЦІЙНО ЗАБРУДНЕНИХ ТЕРИТОРІЯХ

(+) і підсумкових оцінок факторів слабкості підприємства (-), а також iї знак дозволяють оцінити ресурсний потенціал підприємства [3].

У кожному компоненті ресурсного потенціалу підприємства, на думку В. Прохорової, присутня нематеріальна частина, яка включає в себе технології, прийоми й методи керування, господарський механізм, традиції, корпоративну культуру тощо. В остаточному підсумку, вважає автор, саме нематеріальна сфера визначає ту частину ресурсного потенціалу підприємства, що повинна бути залучена у виробничий процес, характер комбінації окремих видів ресурсів та їх збалансованість, відповідно і рівень ефективності використання всього потенціалу [4]. Поділяючи такий підхід, водночас вважаємо за необхідне доповнити його: матеріальна частина ресурсного потенціалу також здійснює вплив на його нематеріальну частину, адже способи й умови використання ресурсів значною мірою залежать від їх кількості та якості.

На нашу думку, процес використання ресурсного потенціалу підпорядковується законам кругообігу ресурсів: результати використання ресурсного потенціалу забезпечують його відтворення для здійснення наступного виробничого циклу на простій або розширеній основі. Виходячи 3 цього, ресурсний потенціал маємо розглядати не тільки як системну, але й як динамічну категорію, що може здійснювати свої кількісні та якісні характеристики у процесі використання. За результатами використання, під впливом зовнішніх чинників, а також в процесі свідомого управління може змінюватися склад (структура) ресурсного потенціалу.

Разом 3 тим, склад ресурсного потенціалу в кожний момент визначає спосіб його використання, в першу чергу виробничу спеціалізацію сільськогосподарського підприємства. Наявна взаємна залежність i взаємна зумовленість процесів використання i відтворення ресурсного потенціалу, що проявляється в часі. Отже, для дослідження процесу функціонування та розвитку системної $\mathrm{i}$ динамічної категорії ресурсного потенціалу, а також для аналізу ефективності його використання та відшукання результативних методів управління ресурсним потенціалом варто скористатися методологічними принципами, що складають ядро еволюційної парадигми або парадигми синергетики.

Виходячи 3 методологічних принципів синергетики, розвиток складної економічної системи понад усе визначається іiі внутрішніми механізмами розвитку, а не зовнішнім середовищем. Отже, інструменти господарського механізму, які суттєво визначають характер використання та відтворення ресурсного потенціалу, мають розглядатися як внутрішні елементи досліджуваної системи. Процес реалізації сільськогосподарської продукції разом 3 ресурсним комплексом радіаційно забрудненої території $\epsilon$ підстави розглядати як елементи системи використання ресурсного потенціалу.

Іншим методологічним принципом синергетики є трактування розвитку системи як "поєднання і чергування процесів підтримки старого порядку, хаосу та створення нового порядку" [5, с. 76]. Це означає, що формування нових раціональних засад ресурсовикористання 3 необхідністю має супроводжуватися руйнуванням традиційних неефективних схем, можливо, банкрутством окремих господарств. Причому, ініціатива щодо банкрутства чи реорганізації сільськогосподарських підприємств має виходити від самих суб'єктів господарювання, у даному випадку - 3 причини систематичної неможливості ефективного використання наявного ресурсного потенціалу.

У цьому контексті необхідно наголосити, що процеси ліквідації чи реорганізації одних та появи нових аграрних формувань не повинні сприйматися як певна соціально-економічна проблема, що призводить до загострення ситуації у конкретному регіоні. Важливо зрозуміти, що левова частка наявного ресурсного потенціалу (земля, трудові ресурси, виробничі споруди тощо) нікуди не зникає, вона лише чекає ефективнішого господаря. Висловлюючись категоріями політичної економії, має відновитися рівновага між рівнем розвитку продуктивних сил і виробничих відносин.

Третій методологічний принцип синергетики передбачає, що розвитку складної економічної системи притаманна невизначеність та нелінійність. Згідно з цим принципом, дослідження проблеми ефективного використання ресурсного потенціалу сільськогосподарських підприємств на радіаційно забруднених територіях має виходити 3 того, що погодні умови та ринкова кон'юнктура містять елемент випадковості і роблять процес використання ресурсного потенціалу слабо прогнозованим. Отже, 3 метою здійснення управлінського впливу з усієї сукупності чинників, що визначають ефективність використання ресурсного потенціалу, необхідно виділити суттєві, які більше детермінують указаний потенціал.

Невизначеність і нелінійність функціонування ресурсного потенціалу як системи ставить проблему обов'язкового виявлення та врахування ризиків у процесі планування та здійснення ресурсовикористання на підприємстві. Ризики, як чинники ефективності використання ресурсного потенціалу, можуть бути поділені на 
Збродська О. В.

природнокліматичні, екологічні, технологічні, комерційні, фінансові. Розглянемо вказані групи ризиків детальніше.

Специфіка сільськогосподарського виробництва полягає у тому, що багато технологічних процесів відбувається на відкритому повітрі за участю сил природи (сонця, вітру, дощу тощо). Як правило, вибір виробничої спеціалізації, підбір сортів рослин і порід тварин, терміни та інтенсивність технологічних операцій здійснюються з урахуванням клімату місцевості, середньостатистичних показників температури $і$ вологості. Водночас періодично трапляються екстремальні відхилення погодних показників від норми, внаслідок чого може порушуватися технологічний процес, виникають ризики невідповідності між обсягами вкладених ресурсів і отриманих результатів.

У межах даного дослідження особливо актуальним є врахування екологічних ризиків, оскільки радіаційне забруднення території негативно відображається на якості продукції, умовах праці, вимагає застосування специфічних технологій виробництва. Крім радіаційного забруднення, до поширених у сільському господарстві екологічних ризиків можна віднести водну та вітряну ерозію земель, закислення, перезволоження, надмірне ущільнення грунтів, забруднення повітря промисловими викидами тощо. Наявність екологічних ризиків може погіршувати якість і продуктивність самих ресурсів, ускладнювати і зменшувати результативність процесу виробництва, призводити до зменшення ціни реалізації готової продукції.

Технологічні ризики характерні для будьякого виробництва, у т. ч. й сільськогосподарського. До них можна віднести неправильний підбір насіння, кормів, добрив, засобів захисту рослин, ветеринарних препаратів тощо; передозування чи недостатній обсяг використання певних ресурсів; порушення термінів, послідовності чи інтенсивності окремих технологічних операцій; вихід 3 ладу техніки чи інших засобів праці тощо. Навіть наявність найкращих за видами і якістю ресурсів не гарантує ефективного їх використання при порушенні технологічних вимог.

Вплив комерційних ризиків для сільськогосподарського підприємства може відчуватися на етапі закупівлі зі сторони певних видів ресурсів чи на етапі продажу виробленої продукції. У першому випадку ризиком для підприємства буде підвищення цін продажу ресурсів, у другому - зниження цін реалізації продукції у порівнянні з плановим рівнем. У результаті, це може негативно вплинути на структуру чи якість ресурсного потенціалу: зменшення обігових коштів, здорожчання ресурсів, відсутність достатнього прибутку можуть завадити підприємству сформувати повноцінний ресурсний потенціал, здійснити необхідні витрати в процесі його використання.

Відчутних втрат сільськогосподарське підприємство може зазнати і внаслідок негативної дії фінансових ризиків. До форм їх прояву передусім можна віднести зростання процентних ставок за кредитами, порушення платіжної дисципліни з боку покупців продукції, зростання податкових ставок, несприятлива зміна валютного курсу при здійсненні підприємством зовнішньоекономічних операцій тощо. Специфічною ознакою цієї групи ризиків $є$ те, що підприємство практично ніяк не може вплинути на їх появу і в багатьох випадках навіть не може передбачити момент їх виникнення.

Четвертий методологічний принцип синергетики передбачає суттєву роль суб'єктивного чинника у визначенні напрямку розвитку системи в точці біфуркації. Під нею розуміємо випадки, коли розвиток системи чи окремих процесів у іiі межах може мати два i більше можливих напрямки. Вибір одного з цих напрямків якраз і здійснюється суб'єктами менеджменту різних рівнів. Відповідно, і подальша ефективність розвитку системи значною мірою залежатиме від компетентності прийнятого управлінського рішення.

У нашому випадку прийняття управлінських рішень керівниками чи менеджерами сільськогосподарських підприємств підпорядковується певним економічним, екологічним, політичним та іншим нормам. Практичне визначення ключової норми достатньо складне, а інколи - неможливе, оскільки може передбачати необхідність перебору великої кількості комбінацій вказаних норм. Існує можливість застосування емпіричних методів дослідження і виділення найбільш вагомих аттракторів, тяжіння до яких обумовлює вибір тієї чи іншої стратегї̈ використання ресурсного потенціалу.

Практика показує, що в сільському господарстві отримання прибутку в багатьох випадках не $є$ домінуючим чинником при прийнятті управлінських рішень, адже в Україні роками функціонують тисячі збиткових сільськогосподарських підприємств. Тому є всі підстави зробити припущення, що більшість аттракторів в системі формування стратегій ресурсовикористання знаходяться у позаекономічних сферах, принаймні за межами офіційної економіки. Серед них можна виділити прагнення зберегти робочі місця (іноді навіть неефективні), намагання забезпечити виробництво 

НА РАДІАЦІЙНО ЗАБРУДНЕНИХ ТЕРИТОРІЯХ

традиційного набору сільськогосподарської продукції (зерно, молоко, м'ясо) незалежно від його ефективності, прагнення включити до складу сільськогосподарських угідь навіть непридатні чи малопридатні для цього землі, неприйняття або побоювання нових технологій чи видів продукції, певний диктат з боку переробних підприємств чи трейдерів тощо.

Особлива група аттракторів існує для суб'єктів господарювання, розташованих на радіаційно забруднених територіях. Більшість 3 них визначена діючим законодавством про особливий статус таких територій: заборона господарського використання окремих земель чи інших ресурсів, вимоги щодо доплат окремим категоріям працівників, посилений контроль якості та безпеки виробленої продукції, вимоги застосування окремих технологій тощо. 3 іншого боку, $\epsilon$ можливість скористатися певними пільгами, передбаченими для тих, хто готовий займатися виробництвом в таких особливих умовах.

П'ятий методологічний принцип синергетики передбачає існування деякої оптимальної будови системи, до якої вона наближається в періоди стійкого розвитку або віддаляється в періоди хаотизації (трансформації). Для ресурсного потенціалу підприємства як системи така будова передбачає поєднання відповідного набору елементів (структури ресурсного потенціалу), прогресивних технологій використання потенціалу i виважених управлінських рішень. Критерієм оптимальності будови такої системи може слугувати наявність постійного (з року в рік) розширеного відтворення ресурсного потенціалу підприємства.

Забезпечення розширеного відтворення ресурсного потенціалу в сільському господарстві можна розглядати у різній часовій перспективі. 3 одного боку, інтенсивне використання наявних ресурсів, передусім земельних, без вкладання особливих коштів у їх відновлення може забезпечити суб'єкту господарювання максимально можливий рівень поточного прибутку. 3 іншого боку, таке використання ресурсного потенціалу може призвести до його виснаження та різкого падіння обсягів виробництва і доходів у майбутньому.

Альтернативою такому стану речей може бути поступове нарощування ресурсного потенціалу 3 постійним оперативним відновленням тих його елементів, які зазнали певного зношення чи втрат. Така система потребує відпрацьованого механізму постійно діючого моніторингу стану ресурсного потенціалу, його відтворювальних потенцій. Оскільки в багатьох випадках користувачі ресурсами в сільському господарстві (передусім землею і технікою) не є їх власниками, то у створенні згаданої системи моніторингу в першу чергу мають бути зацікавлені власники ресурсів і держава як захисник суспільних інтересів.

Формування стратегічного мислення i, відповідно, прагнення приймати стратегічні рішення у сфері формування та використання ресурсного потенціалу є складним завданням. Як показує практика, в країнах 3 ринковою економікою більшого ефекту вдається досягти при застосуванні економічних, а не адміністративних методів. Враховуючи це, доцільне є впровадження такої системи, при якій ефективність використання ресурсного потенціалу сільськогосподарських підприємств оцінюватиметься не стільки за поточним прибутком, скільки за наявністю у суб'єкта господарювання можливостей для швидкого і якісного розвитку ресурсного потенціалу, який забезпечить вищі прибутки у майбутньому.

У цьому відношенні варто погодитися 3 думкою В. Сіденка про те, що для суб'єктів господарювання (як і для економіки в цілому) критерій максимізації прибутку має бути доповнений критеріями темпів i якості економічного розвитку. Цитуючи відомого німецького економіста Ф. Ліста, В. Сіденко наголошує на тому, що здатність створювати багатство набагато важливіша за саме багатство, оскільки вона не лише забезпечує володіння набутими благами та їх збільшення, але й відшкодовує втрачене [5, с. 24]. Звідси можна зробити висновок про те, що важливим стратегічним чинником ефективності використання ресурсного потенціалу сільськогосподарських підприємств є здатність цього потенціалу до самовідновлення.

Важливо встановити, від чого залежить така здатність до самовідновлення. Тут можна виділити чинники внутрішньої і зовнішньої дії. До першої групи передусім можна віднести відповідність спеціалізації підприємства природнокліматичним і технологічним умовам, ефективність менеджменту, розвиненість виробничої і соціальної інфраструктури, рівень використовуваних технологій, рівень контролю усіх стадій виробництва і реалізації продукції тощо. Зовнішніми чинниками можна вважати обсяг попиту на продукцію підприємства, дотримання паритету цін на сільськогосподарську продукцію і ресурси для їі виробництва, доступ виробників до кредитних ресурсів, створення сприятливого інвестиційного клімату в країні і галузі, рівень оподаткування, рівень інформаційної підтримки товаровиробників, розвиненість ринкової інфраструктури і т. д.

Важливим чинником, який здатний впливати 
Збродська О. В.

на відтворювальну спроможність ресурсного потенціалу сільськогосподарських підприємств та ефективність його використання, є розвиток суміжних галузей. Адже в умовах поглиблення поділу праці суб'єкти господарювання стають дуже залежними від економічного становища тих, хто виробляє і поставляє їм ресурси, а також купує в них готову продукцію. Тому внаслідок дії ефекту мультиплікатора кризові явища в будь-якій із суміжних галузей можуть мати негативні наслідки для економічного стану сільського господарства.

3 погляду формування ресурсного потенціалу, більшої уваги заслуговує стан галузей, що спеціалізуються на виробництві ресурсів для сільськогосподарського виробництва: техніки, добрив, засобів захисту рослин, ветеринарних препаратів, комбікормів тощо. Прогнозування стану в цих галузях простіше в тих випадках, якщо це вітчизняні підприємства, коли на всі суміжні галузі діють однакові макроекономічні чинники. Складніша ситуація за наявності залежності від імпортних поставок: зміна валютних курсів, політика іноземних держав, вплив тарифного і нетарифного регулювання ЗЕД та інші ризики є додатковими факторами невизначеності при розробці стратегії ресурсного забезпечення сільськогосподарських підприємств.

Навіть високоефективне використання ресурсного потенціалу у виробничій сфері не може бути тривалим без забезпечення стабільної та економічно вигідної реалізації виробленої продукції. Лише частина отриманої сільськогосподарської продукції реалізується напряму кінцевим споживачам, більша ж частина - переробним підприємствам. Як правило, переробні підприємства розміщуються максимально наближено до сировинної бази, що дає змогу відносити їх та сільськогосподарські підприємства до сфери компетенції одних регіональних структур управління і навіть сприяти створенню на базі цих підприємств вертикально інтегрованих структур. Саме в межах таких структур переробні підприємства часто сприяють забезпеченню сільськогосподарських підприємств необхідними видами ресурсів на період виробничого циклу.

В умовах ринкової економіки для більшості суб'єктів господарювання важливого (а іноді i вирішального) значення набуває маркетингова діяльність, адже вистояти в умовах жорсткої конкуренції можна лише за наявності ефективної маркетингової стратегії. Оскільки сільськогосподарські підприємства більшу частину продукції реалізують оптовим посередникам і переробним підприємствам, то ключовим завданням їх маркетингової діяльності $\epsilon$ відслідковування вимог до асортименту і якості продукції, яка в конкретний момент часу користується найбільшим попитом на ринку. Знання цих вимог дасть змогу підприємству закупити саме ті ресурси, які дозволять виробити продукцію очікуваної якості та реалізувати іiі за вигідною ціною.

Певний вплив на ефективність використання ресурсного потенціалу підприємства мають соціальні і культурні чинники. Їх прояв, передусім, має місце у формуванні ставлення людей (i працівників підприємства, і просто місцевого населення) до праці, дотримання трудової дисципліни, до прагнення оволодівати новими професіями і технологіями, поваги до приватної власності інших осіб, уміння і бажання мобілізуватися в часи пікового навантаження у виробничій діяльності тощо. Вплив таких чинників фактично є двостороннім, адже ефективне використання ресурсного потенціалу $\epsilon$ передумовою виділення необхідних коштів для створення і розвитку соціальної інфраструктури в регіоні діяльності підприємства: частину цих коштів виділяє сам суб'єкт господарювання, інша частина перерозподіляється у вигляді місцевих податків і зборів.

Радіаційно забруднені території, на землях яких функціонують сільськогосподарські підприємства, є складовою регіону, що відноситься до категорії депресивних. Держава, яка сама постійно відчуває нестачу бюджетних коштів, не може в достатній мірі профінансувати необхідні заходи соціально-економічного розвитку регіону, який переважно є аграрним. Тому потрібно шляхом реалізації заходів 3 покращення використання ресурсного потенціалу саме сільськогосподарських підприємств забезпечити зростання добробуту в регіоні.

Отже, ефективність використання ресурсного потенціалу підприємств аграрної сфери радіаційно забруднених територій залежить від цілого ряду чинників. Указані чинники можна поділити на дві групи: чинники формування ресурсного потенціалу та чинники його ефективного використання (рис. 1.).

Представлені чинники можуть бути поділені на керовані та некеровані з погляду окремого суб'єкта господарювання. Керованими будемо вважати ті чинники впливу, виникнення і сила дії яких може регулюватися самим підприємством. До цієї категорії є підстави віднести якісний склад матеріальних і трудових ресурсів, маркетингову політику підприємства, рівень організації та управління на підприємстві тощо.

Некеровані - це так звані чинники зовнішнього впливу, появу та інтенсивність яких підприємство в кращому випадку може передбачити, але впливати на них змоги не має. Такими чинниками 


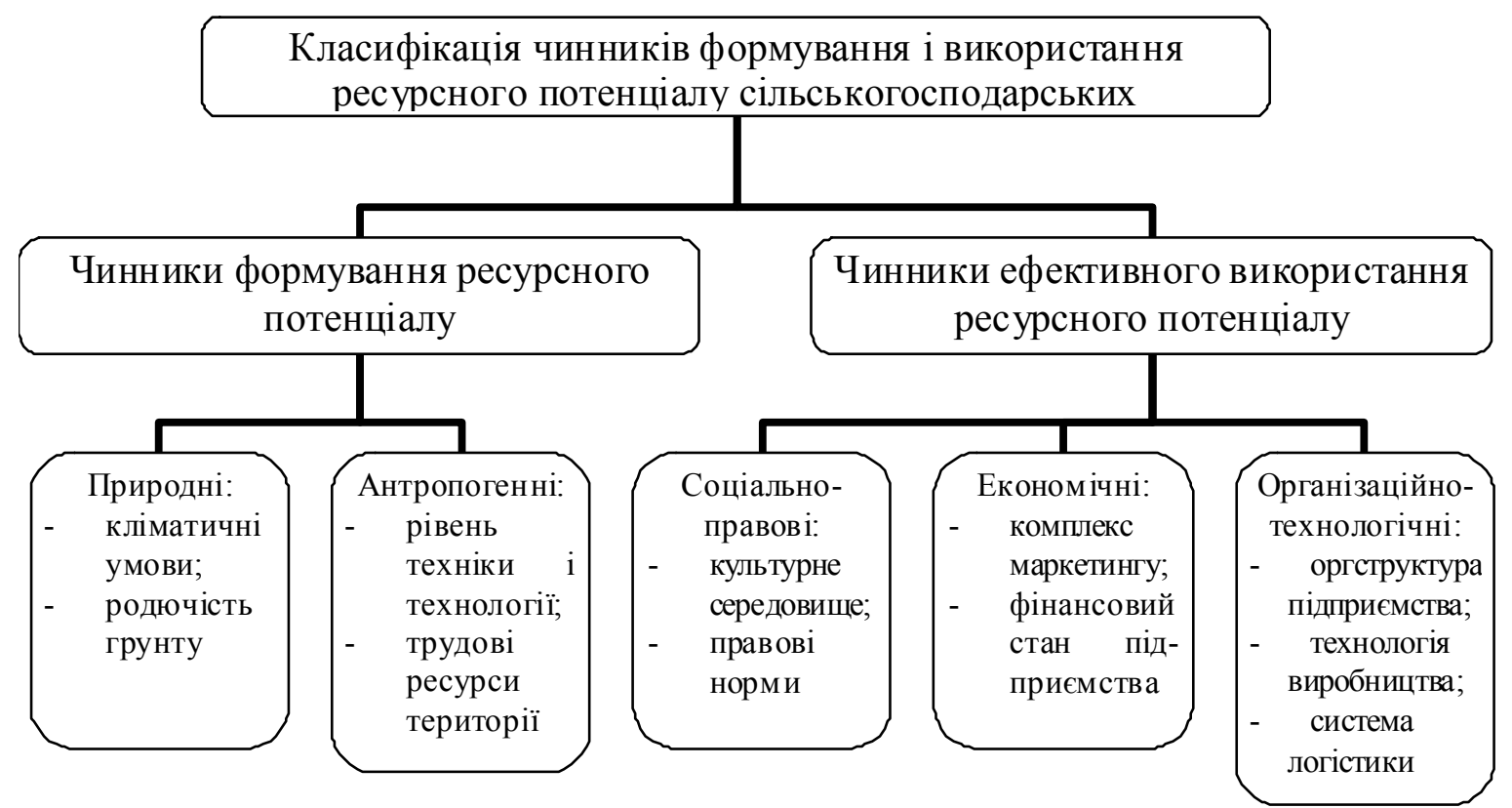

Рис. 1. Класифікація чинників формування і використання ресурсного потенціалу сільськогосподарських підприсмств

$\epsilon$ кон'юнктура ринків ресурсів та готової продукції, дають змогу підприємству сформувати i дії уряду, погодні умови і т. п. Також можна реалізувати свій ресурсний потенціал. Це вагомий виділити частково керовані чинники: наприклад, засіб впливу на економічний потенціал суб'єкта родючість грунту залежить від якості конкретної господарювання (рис. 2). земельної ділянки, але може бути поліпшена відповідними агротехнічними заходами.

Таким чином, розглянуті в даній статті чинники

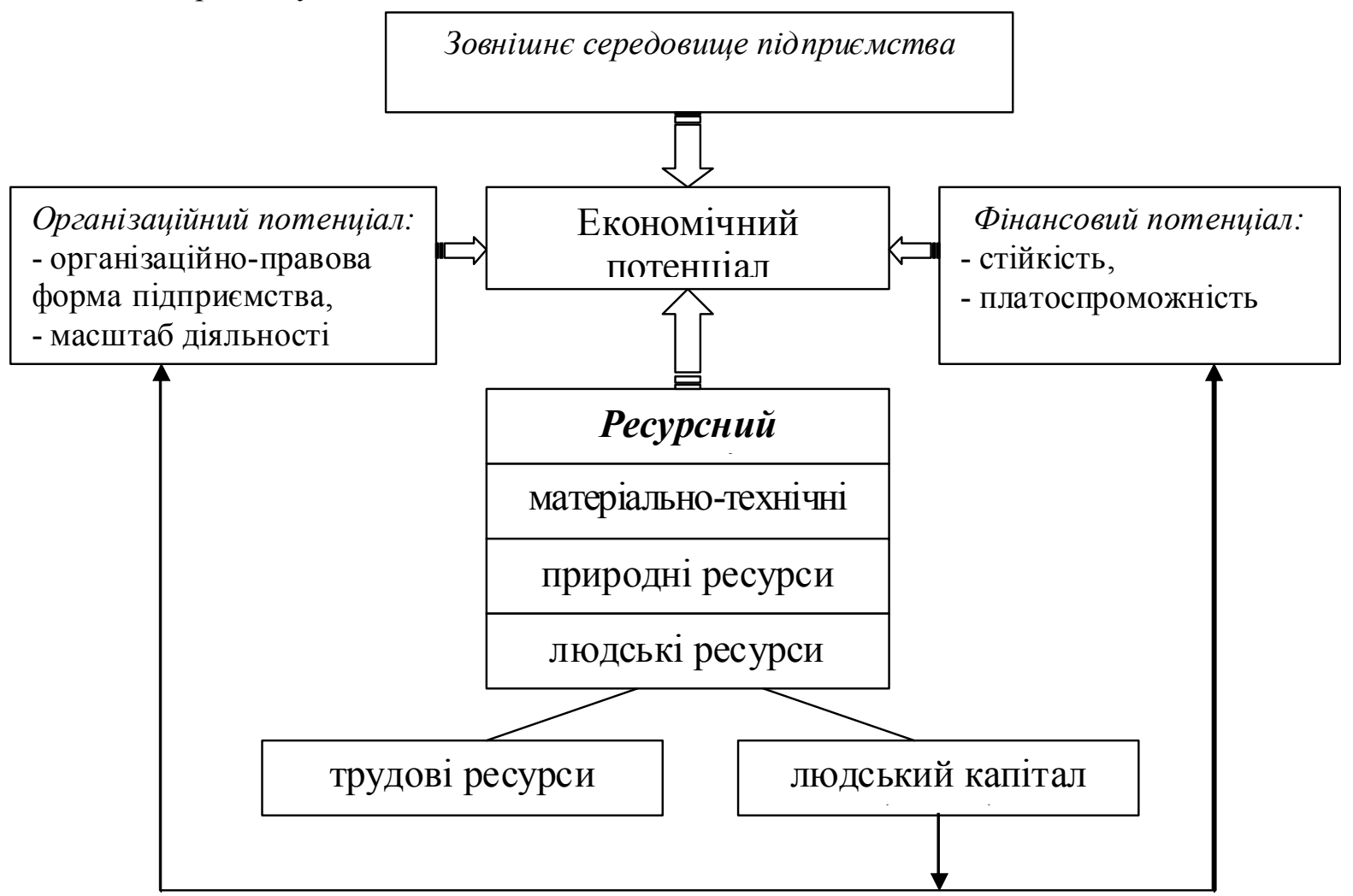

Рис. 2. Складові та чинники економічного потенціалу сільськогосподарського підприсмства 
Збродська О. В.

Як видно з представленої схеми, економічний потенціал підприємства визначається його ресурсним, організаційним і фінансовим потенціалом, а також впливом зовнішнього середовища. Причому, $\epsilon$ всі підстави стверджувати, що для сільськогосподарського підприємства вирішальне значення в цій схемі має саме ресурсний потенціал. Адже без його формування і використання не відбудеться сам процес виробництва, специфікою якого $є$ тривалість більшості технологічних процесів і участь природних факторів у створенні матеріального продукту.

Вирішальний вплив ресурсного потенціалу підприємства на рівень його потенціалу економічного дозволяє стверджувати, що й чинники ресурсного потенціалу одночасно $€$ чинниками економічного потенціалу суб'єкта господарювання. У процесі впливу цих чинників зовнішнє середовище виконує роль своєрідного каталізатора, тобто може посилювати або послаблювати дію окремих чинників чи їх сукупності. Враховуючи це, держава, місцеві органи влади, галузеві чи територіальні об'єднання та інші інституційні утворення, які виступають суб'єктами зовнішнього середовища підприємства, можуть своїми діями чи бездіяльністю суттєво впливати на процес формування та ефективність використання ресурсного потенціалу сільськогосподарських підприємств.

Перелік і ступінь впливу вищезазначених чинників можуть днщо відрізнятися, залежно від місця розташування, розміру, спеціалізації, економічного стану суб'єкта господарювання. Наявність радіаційно забруднення також $є$ вагомим чинником ефективності використання ресурсного потенціалу для тих сільськогосподарських підприємств, що розташовані на відповідних територіях. Зменшення негативного впливу цього чинника можливе за рахунок відповідного кількісного і якісного удосконалення інших складових ресурсного потенціалу відповідних суб'єктів господарювання.

Отже, ефективність використання ресурсного потенціалу підприємств аграрної сфери радіаційно забруднених територій залежить від цілого ряду чинників, які можна поділити на дві групи: чинники формування ресурсного потенціалу та чинники його ефективного використання. Представлені чинники можуть бути поділені на керовані, частково керовані та некеровані 3 погляду окремого суб'єкта господарювання.

\section{Список літератури}

1. Кібук Т.М. Стратегічний потенціал підприємства та його види // www. rusnauka. com/18_NiIN_2007/ .../23135.doc/htm

2. Березін О.В. Завдання та механізми оптимізації структури потенціалупідприємства /О.В.Березін, Н.Б. Кушнір // Вісник національного університету водного господарства та природокористування: Зб. Наук. Праць. - Рівне: НУВГП, 2007. - Ч.2, вип.4. - С.2027. - (Сер. "Економіка )

3. Шаманська О.І. Оцінка ефективності управління економічними ресурсами підприємства // http// www.rusnauka.com

4. Прохорова В.В. Ресурсний потенціал економічного зростання // www. nbuv.gov.ua

5. Сиденко В.Р. Глобализация - европейская интеграция - экономическое развитие: украинская модель: В 2-х т. Т. 1. Глобализация и экономическое развитие. - К.:Феникс, 2008 - 376 с. 


\section{ФАКТОРЫ ИСПОЛЬЗОВАНИЯ РЕСУРСНОГО ПОТЕНЦИАЛА СЕЛЬСКОХОЗЯЙСТВЕННЫХ ПРЕДПРИЯТИЙ НА РАДИАЦИОННО ЗАГРЯЗНЕННЫХ ТЕРРИТОРИЯХ}

Рассмотрены основные факторы использования ресурсного потенциила на радиационно загрязненных территориях. Установили перечень внутренних и внешних факторов, которые определяют эффективность использования ресурсного потенциила, а такэе оченили степень влияния каждого из выявленных факторов. Исследован процесс функиионирования и развитие системного и динамической категории ресурсный потенциал с помощью методологических принципов синергетики.

Ключевые слова: ресурсный потенциил, сельскохозяйственное предприятие, принципь синергетики, экономический потенциал, радиационно загрязненные территории.

Summary

Olga Zbrodska

\section{FACTORS OF USE OF THE RESOURCE POTENTIAL OF AGRICULTURAL ENTERPRISES IN THE RADIOACTIVE POLLUTED TERRITORIES}

There are considered the basic factors of use of the resource potential of the radioactive polluted territories. Set the list of internal and external factors, which determine the effectiveness of the use of the resource potential, as well as to evaluate the influence of each of the factors identified. The process of functioning and development of system and dynamic categories of the resource potential with the help of the methodological principles of synergetics.

Key words: resource potential, the agricultural enterprise, the principles of synergetics, the economic potential, the radiation contaminated areas. 
УДК: 654 (045)

\author{
(C) Каліна I.І., Шуляр Н.М., 2011 \\ Національний авіаційний університет, м.Київ
}

\title{
ПОТЕНЦАЛ ІНФОРМАТИЗАЦЇ̈ ГАЛУЗІ ЗВ'ЯЗКУ В КОНТЕКСТІ КОНКУРЕНТНОГО СЕРЕДОВИЩА
}

\begin{abstract}
Розглядається економічний зміст, функиії, види інформації та ї̈ роль в галузі зв'язку, щзо являс собою найбільш специифічну сферу економічної діяльності, а також вплив потенціалу зв'язку на забезпечення необхідною інформатизацією, тобто до більш швидкого аналізу, обробки та прийняті рімень, що призводить до економічного розвитку підприємств та держави в конкурентному середовищі.

Ключові слова: потенціал, інформачія, зв'язок, конкурентне середовище
\end{abstract}

Постановка проблеми. Однією і з стратегічних галузей економіки кожної країни виступає сфера телекомунікаційних послуг, яка відіграє величезну роль у збалансованому соціально-економічному розвитку суспільства та країни взагалому. Вона $\epsilon$ з'єднувальною ланкою як між виробництвом i сферою послуг, так і їх споживачами, в різних географічно розрізнених частин країни. Стимулюючи людське спілкування за допомогою зв'язку, сучасні засоби телекомунікацій стають необхідною умовою для інформатизації суспільства.

Уже тепер неймовірно збільшені потоки інформації - телефонні розмови, факсимільна інформація, електронна пошта, радіо та телебачення. Світ стає ще більш залежним від засобів телекомунікацій, які змінюють бізнес, стиль життя, суспільство в цілому. Так, діти в Сінгапурі застосовують пейджинг або стільниковий телефон для підтримання зв'язків 3 батьками, а аборигени Австралії продають свій живопис, використовуючи можливості відеоконференції, бразильські банки пропонують свої послуги в мережі Інтернет. Мешканці України також використовують стільникові телефони для зв'язку з рідними, а також Інтернет для придбання будь-якого товару (послуги).

Всесвітня інфраструктура зв'язку, яка формується, i можливості світових телекомунікацій, що швидко розвиваються, сприяють становленню інформаційної і глобальної. А розвиток економіки стимулює розвиток зв'язку. Швидко зростає кількість підприємств, підприємців, які, працюючи у віртуальних офісах, зв'язуються лініями зв'язку та Інтернет з іншими підприємствами і підприємцями в різних частинах світу i, не користуючись засобами транспорту, розв'язують багато економічних проблем. За допомогою зв'язку здійснюється більшість економічних трансакцій як усередині держав, так i у всесвітньому масштабі. Зв'язок починає заміняти і витісняти деякі комунікаційні магістралі.

Сучасний етап економіки зв'язку України характеризується іï стабільним розвитком з більш високими темпами зростання основних показників, ніж в інших галузях економіки країни. У галузі розпочато економічні перетворення, націлені на створення умов функціонування повноцінних ринкових відносин. Але, порівняно з іншими розвиненими країнами, економіка зв'язку України суттєво відстає у використанні нових технологій, у розвитку мережі Інтернет, за обсягом надаваних послуг зв'язку та за іншими показниками.

Аналіз останніх досліджень і публікацій. У тій чи іншій мірі вітчизняні та зарубіжні вчені економісти велику увагу приділяли та приділяють темі розвитку та ролі галузі зв'язку, серед яких Орлов В.Н., Бурило Ю.П., Воронін І.М., Булах І.В., Войтко С.В., Додд Аннабел 3., Мильчакова Н.

Аналіз наукових досліджень цих авторів показав, що проблемам розвитку інформатизації галузі зв'язку приділено чималу увагу, однак потенціал розвитку даної галузі досліджено не по всіх параметрах. Тому потребує більш глибокого аналізу конкурентоспроможних підприємств в галузі зв'язку та їх потенціал інформатизації.

Мета статті - обгрунтування ролі галузі зв'язку та іiї потенціал інформатизації в контексті конкурентного середовища.

Виклад основного матеріалу. У багатьох країнах світу сектор послуг вже утворює близько половини їх валового національного продукту. Така тенденція не обмежується лише економічно розвинутими державами. Так, наприклад, в Гонконгу або Угорщині, сектор послуг забезпечує до $60 \%$ економічної активності країни. Навіть у найменш розвинутих країнах частка сектору послуг $(43 \%)$ перевищує частку сільськогосподарського сектору (на 37\%) або промислового (на 20\%). Отже, світ перебуває в стані інформаційної революції, тобто обробка інформації - одна з найвагоміших складових економічного розвитку. Тому можна 
ПОТЕНЦАЛ ІНФОРМАЦІЇ ГАЛУЗІ ЗВ ЯЗКУ В КОНТЕКСТІ КОНКУРЕНТНОГО СЕРЕДОВИЩА

стверджувати, що розвиток телекомунікацій, як важлива складова інформатизації суспільства та забезпечення населення високоякісними послугами зв'язку, є одним 3 найважливіших напрямів соціально-економічного зростання.

Зв'язок - одна 3 галузей суспільного виробництва, функції якої полягають у наданні споживачам послуги для здійснення різного виду повідомлень: листів, телеграм, телефонних розмов, програм радіо та телебачення, даних та інших видів інформації. Надання всім сферам суспільного виробництва і населенню послуг зі збору, обробці та передачі інформації, надає зв'язку риси галузі матеріального виробництва [2].

Галузь зв'язку являє собою найбільш специфічну сферу економічної діяльності. Перш за все, вона має нематеріальний характер продукції. По-друге, їі особливістю є нерозривність процесів виробництва та споживання послуг зв'язку. Послуги зв'язку отримуються споживачами у процесі їх виробництва. Наявно це можна простежити в системі телефонного зв'язку, де сам процес передавання телефонного повідомлення та процес виробництва відбувається за участю абонентів, тобто збігається з процесом споживання.

Процес передачі інформації завжди двосторонній, тобто відбувається між відправником та отримувачем інформації. Оскільки необхідність у передачі інформації може виникнути між абонентами, які знаходяться у різних населених пунктах, це потребує створення стійкої, надійної, розгалуженої мережі зв'язку, що поєднує всі населені пункти між собою.

Послугами зв'язку користуються мільйони абонентів, як юридичних, так і фізичних осіб. Саме 3 цієї причини оператори зв'язку розміщені практично у всіх містах і населених пунктах i створюють єдину мережу зв'язку. Ця мережа складається 3 ліній та каналів зв'язку, які, взаємодіючи, забезпечують двосторонній процес передачі інформації. Залежно від характеру інформації, що передається у виробничому процесі закінченої послуги, можуть бути задіяні два, три і більше операторів, які при цьому можуть мати різну відомчу належність. Тобто оператори зв'язку, що надають послуги, не завжди є єдиним їх виробником.

А це означає, що в галузі зв'язку виробничий процес не завершується в межах одного оператора зв'язку, закінчені послуги беруть участь декілька фінансово й організаційно самостійних операторів. Вони виконують різні технологічні операції у процесі надання послуги споживачам, що вимагає взаємодії усіх учасників процесу виробництва послуг зв'язку.

3 технічного боку дана особливість галузі вимагає єдності побудови мережі зв'язку, наявності ефективного техніко-технологічного механізму сполучення обладнання, дотримання єдиних правил технічної експлуатації та ін. 3 економічного - потребує створення умов для прозорого економічного партнерства операторів, яке забезпечує їх економічні інтереси. Ці умови повинні створювати регуляторні чинники конкурентних відносин між операторами електрозв'язку.

На сьогодні роль у житті людини відіграє інформація. Інформаційні та телекомунікаційні технології породжують індустріальну революцію, не менш значущу, ніж промислові революції минулого, й таку, що матиме далекосяжні перспективи та наслідки. Ця революція базується на інформації, що акумулює людські знання, впливає на інтелект людини. Сучасний технологічний прогрес надає можливість поновому організувати процеси обробки, зберігання, пошуку та передавання інформації в будь-якій потрібній формі [4]. На зміну індустріальному суспільству приходить інформаційне суспільство, в якому діяльність людей здійснюється на основі використання послуг, що надаються за посередництвом операторів зв'язку.

Діяльність окремих людей, груп та організацій, усе в більшій мірі, починає залежати від їхнього інформування і здатності ефективно використовувати наявну інформацію. Перш ніж розпочати певну діяльність, необхідно провести роботу зі збору і переробки інформації, ii осмислення й аналізу. Пошук раціональних рішень у будь-якій сфері вимагає обробки великих обсягів інформації, що неможливо без залучення спеціальних технічних засобів зв'язку.

Бурхливий розвиток інформаційних технологій, комунікаційних мереж, засобів зв'язку та доступу до різноманітної інформації, що ми сьогодні спостерігаємо, не могли не позначитися на соціальній сфері, на суспільних відносинах. Новітні технології відіграють дуже велику роль в будьякому суспільстві - вони дозволяють швидко обробляти величезну кількість інформації, змінюють структуру комунікації між людьми, в цілому відбиваються у всіх сферах людського життя.

У зв'язку 3 тим, що за допомогою інформаційних технологій прискорюється процес прийняття рішень та їхнього втілення, вивільняється частина робочого часу людини та росте необхідність в нових знаннях, потреба у відповідних послугах, а також економічний розвиток підприємства. Цей процес проявляється в зміні соціальної структури суспільства, його переорієнтації та деякій трансформації цінностей, тоді як швидкість і масштаби його протікання весь 
Каліна I.I., Шуляр Н. М.

час збільшуються. Це не могли не помітити філософи та політологи, досліджуючи процес суспільного прогресу в розвинених країнах, що i привело до появи теорії постіндустріалізму, інформаційного суспільства. Наразі в світі відбувається величезне зростання обсягів інформації, знання диференціюється та спеціалізується, неминуче зростає сфера послуг, тому процес становлення інформаційної цивілізації є об'єктивним і закономірним.

Інша річ, що різні держави залежно від свого інтелектуального, наукового, технологічного рівня розвитку мають різні перспективи щодо цього. Високорозвинені держави світу вже пройшли початковий етап становлення суспільства інформаційної демократії, інші знаходяться на заключній фазі індустріалізму, треті - ще не мають навіть більш-менш розвиненого індустріального сектора. Але, так чи інакше, світ усе більше залежить від влади інформації. Основною сферою національної економіки, яка є носієм інформації між різними суб'єктами ринку та суспільства, $є$ галузь зв'язку.

Інформаційно-комунікаційні технології за умов належного використання стають потужним засобом електронного залучення, економічного розвитку та демократизації суспільних процесів. Разом 3 тим вони сприяють новим поділам між країнами та окремими регіонами за економічними та технологічними ознаками [1].

У сучасному суспільстві інформація стає найбільш важливою цінністю, а індустрія отримання, обробки і трансляції інформації провідною галуззю діяльності, куди 3 кожним роком вкладаються все більш значні капітали. Інформатизація суспільства виступає одним 3 вирішальних чинників модернізації економіки на ринкових засадах і запорукою інтеграції України в світове співтовариство.

Важлива передумова інформатизації суспільства - розвиток сучасної національної інфраструктури інформатизації, складовою якої є: телекомунікаційна техніка, мережні інформаційні технології, сукупність інформаційних ресурсів, прикладні інформаційні технології, засоби обчислювальної техніки, мережне обладнання та програмне забезпечення, прикладні інформаційні технології, система забезпечення інформаційної безпеки, сукупність кваліфікованих кадрів i система їхньої підготовки та перепідготовки тощо [3].

У нашій країні розв'язання проблеми побудови інформаційного суспільства займає важливе місце, оскільки інформаційні технології стрімко стають одним з найприбутковіших та швидко зростаючих секторів економіки.

Одним $з$ основних елементів інформаційного суспільства є розвинена система мережі електрозв'язку. Сьогодні вже багато зроблено для iii оновлення та удосконалення - створено сучасну міжміську телефонну мережу з виходом за межі країни, а також цифрову мережу міжнародного та міжміського телефонного зв'язку; швидкими темпами розвивається супутниковий та мобільний зв'язок. Однак, попри розуміння важливості рішень стосовно інформатизації, технічний рівень і масштаби застосування інформаційних технологій в Україні залишаються значно нижчими порівняно 3 європейськими показниками. Зокрема рівень охоплення дорівнює:

- фіксованими телефонними лініями зв'язку в Україні - 30\%, у Свропі - 40\%;

- мобільною телефонією в Україні - 25,5\%, у Європі - 70\%; $56 \%$.

- Інтернетом - в Україні 15,5\%, у Свропі -

За темпами щорічного приросту всіх видів інформаційних ресурсів Україна значно випереджає країни Свропи у зв'язку з істотною ненасиченістю вітчизняного ринку цими технологіями .

Інформатизація суспільства неможлива без забезпечення комп'ютерною технікою та доступом населення до мережі Інтернет. Щорічне зростання кількості персональних комп'ютерів в Україні складає орієнтовно 50\%. Так, з близько п'ятисот тисяч їх кількість за останні чотири роки зросла майже у 3 рази і склала у 2006 році біля півтора мільйона одиниць, а в 2010 році процес комп'ютеризації зріс майже на 65\%. При цьому технології розвиваються настільки бурхливо, що техніка оновлюється кожні два роки.

Якщо шість років тому кількість користувачів мережі Інтернет становила 0,2\% населення України, то сьогодні вже понад 15\%. Надання послуг доступу до Інтернету забезпечено в усіх великих містах, обласних i багатьох районних центрах. Сьогодні послугами мережі Інтернет користується близько 16 мільйонів громадян України. Високими темпами зростає обсяг інформаційних ресурсів, створених в Україні, зокрема щоденно з'являється близько 50 нових веб-сайтів. Незважаючи на позитивну динаміку, загальний рівень використання Інтернету залишає бажати кращого. Переважна більшість користувачів - майже 70\% - зосереджена у великих містах. Більше 20\% всіх користувачів - у Києві, у сільській місцевості - лише 10\% .

За тридцять років існування Інтернет переріс iз секретної технології, яку використовували науково-дослідні установи, що працювали на військові і розвідувальні програми Уряду США, у загальнодоступну, відкриту інформаційну систему. В останні роки Інтернет упевнено перейшов на 
комерційні засади розвитку і став важливим фактором розвитку як світової, так і національних економік окремих країн.

Із вищевказаного випливає, що незначна комп'ютеризація населення та відставання рівня Інтернет-ринку від розвинених країн світу не $\epsilon$ перешкодою для формування інформаційного суспільства.

Отже, основними характеристиками інформаційного суспільства можна вважати такі:

- інформація використовується як економічний ресурс;

- інформація стає предметом масового споживання населення;

- швидкими темпами формується та зростає інформаційний сектор економіки;

- збільшення можливостей людини обробляти інформацію;

- передавання та отримання інформації здійснюється в основному за посередництвом технічних засобів зв'язку.

Держава розподіляє частоти, номерні ресурси, сертифікує АТС, але все це - технології минулого століття. Технології майбутнього - електронний документообіг, електронні послуги та послуги, пов'язані з використанням цифрового підпису, електронна комерція та державні закупівлі, комп'ютерна звітність і платежі, мобільні комп'ютери, IP - телефонія, цифрове телебачення та телебачення на замовлення, а також їхня безпека використання.

Висновок. Потенціал інформатизації країн світу залежить від розвитку телекомунікацій, адже без інформації не може обійтися ні людина, ні підприємство, ні держава. На сьогодні основною роллю зв'язку $є$ забезпечення необхідною інформацією, що призводить до більш швидкого аналізу, обробки та прийняття рішень, що веде до економічного розвитку як підприємства, так i держави в цілому. Але необхідність у розвитку сфери зв'язку полягає в розробці електронних каталогів (приведення всіх даних в електронний вигляд), що призведе бо більш ефективної роботи підприємства та зовнішньоекономічного розвитку держави.

\section{Список літератури}

1. Колодюк А.В. Національні стратегії інформаційного суспільства: переваги та перспективи впровадження в Україні//нфформаційне суспільство. Шлях України.- К.: Бібліотека інформаційного суспільства, 2004.- С. 24.

2. Основы экономики телекоммуникаций (связи): Учебник для вузов/ М.А.Горелик, Е.А. Голубицкая, Т.А. Кузовкова и др.; Под. ред. М.А. Горелик и Е.А. Голубицкой.-М: Радио и связь.-1997.-224с.

3. Стрий Л.А. Роль и место связи в глобальной экономике // Економіка: Проблеми теорії та практики: Зб. наук. пр. ДНУ. - 2002. - Вип. 146. - С. 8090

4. Уваров Р.В., Байраківський А.І., Інформаційне суспільство в Україні: проблеми становлення і розвитку // Матеріали 5-ї міжнародної науковопрактичної конференції "Достижения в телекоммуникациях за 10 лет независимости Украины". - Одеса. 2001. - С.200-201. 


\section{ПОТЕНЦИАЛ ИНФОРМАТИЗАЦИИ ОБЛАСТИ СВЯЗИ В КОНТЕКСТЕ КОНКУРЕНТНОЙ СРЕДЫ}

Рассматривается экономическое содержание, функции, виды информации и ее роль в области связи, что представляет собой наиболее специфическую сферу экономической деятельности, а также влияние потенциала связи на обеспечение необходимой информатизаиии, т.е. к более быстрого анализа, обработки и принятии решений, что приводит к экономическому развитию предприятий и государства в конкурентной среде.

Ключевые слова: потенциал, информация, связь, конкурентная среда.

\section{Summary}

Irina Kalina, Nataliya Shulyar

\section{THE POTENTIAL OF INFORMATISATION OF COMMUNICATION IN THE CONTEXT OF COMPETITIVE ENVIRONMENT}

The article deals with economic content, functions, types of information and its role in communications, which is the most specific scope economic activity and potential impact of communication on ensuring the necessary informatisation, that is, more rapid analysis, processing and the decisions, leading to economic development of enterprises and state in a competitive environment.

Keywords: capacity, information, communication, competitive environment. 
УДК 330.341.1

\author{
(C) Якобчук В.П., Кащук К.М., 2011 \\ Житомирський національний агроекологічний університет, м.Житомир
}

\title{
ФОРМУВАННЯ ТА РОЗВИТОК АГРОІННОВАЦІЙНИХ СТРУКТУР В УКРАЇНІ: ПРОБЛЕМИ ТА ПЕРСПЕКТИВИ
}

\begin{abstract}
Розглядаються науково-методологічні засади формування і розвитку інноваційних структур в аграрній сфері. Визначено основні відмінності між видами інноваційних структур в залежності від їх функиіонального призначення. Обгрунтовано можливості створення агроінноваційних структур у Поліському регіоні.

Ключові слова: науковий парк, дослідний парк, бізнес-інкубатор, інновачійний иентр, науковий потенціал, диверсифікащія, нововведення, агроінноваційна структура.
\end{abstract}

Постановка проблеми. Розвиток інформаційноінтелектуального суспільства значною мірою визначається наявністю й ефективністю інноваційних процесів, які обумовлюють перетворення результатів науково-дослідних робіт у нові продукти, технології, послуги. В цих умовах одним 3 найбільш ефективних механізмів реалізації такого перетворення $\epsilon$ інноваційні структури з широким спектром їх функцій і типів - наукові парки, технопарки, технополіси та інші. Ці утворення формують інноваційну інфраструктуру - сукупність взаємопов'язаних та взаємодіючих підприємств, установ, організацій, необхідних для ефективного здійснення інноваційної діяльності та реалізації нововведень. Україна насамперед має перейняти досвід розвинених країн світу, де підтримка інноваційної інфраструктури $є$ підгрунтям для розвитку інноваційного підприємництва.

Вихідними серед наукових теорій, що досліджують інноваційне підприємництво, інноваційний розвиток, стали праці одного 3 найвидатніших економістів минулого століття Йозефа Алоїза Шумпетера, в яких підприємництво вперше було пов'язане 3 розвитком технологій, нововведеннями та економічним зростанням. Саме таке розуміння через багато років дозволило розглядати підприємство як ключову силу в реалізації досягнень науково-технічного прогресу, створенні інновацій. Для України, яка стала на шлях економічних реформ і перетворень, ідеї Й. Шумпетера про внутрішню стимулюючу роль інновацій мають велике значення для відродження національного господарства в цілому та аграрної сфери, зокрема, як фундаменту економіки країни.

Низький технологічний рівень сільськогосподарського виробництва в Україні та ігнорування принципів раціонального його ведення призводить до подорожчання вітчизняної аграрної продукції, зменшення іiї конкурентоспроможності в порівнянні з продукцією розвинутих країн світу.
Тому розвиток інноваційних процесів безпосередньо в аграрному секторі, створення нових форм інтеграції науки i сільськогосподарського виробництва, методів організації і управління інноваційною діяльністю стає досить актуальним і вимагає свого рішення 3 врахуванням всіх чинників внутрішнього і зовнішнього характеру.

Аналіз останніх досліджень. Наукові дослідження проблеми розвитку інноваційних структур здійснюють такі українські та зарубіжні вчені: В. Андріянов (теоретичні основи наукових парків) [1]; М.М. Іванов, С.Р. Колупаєв (методи управління наукою та нововведеннями в США) [2]; А. Каратаєв (функціонування наукових парків у розвинених капіталістичних державах) [3]; В.К. Васенко (світовий досвід функціонування та стратегія розвитку вільних економічних зон в Україні) [4]; О.А. Мазур (світовий та український досвід функціонування технологічних парків) [5]; B. Семиноженко (технопарки та досвід формування інноваційної економіки) [6]; Д.В. Табачник (світовий та український досвід функціонування технологічних парків) [7], Федулова Л.І. та інші. Однак за межами розгляду залишаються питання практичної реалізації проектів по створенню різних видів інноваційних структур, особливо в аграрному секторі.

Мета і завдання дослідження. Метою дослідження $\epsilon$ обгрунтування науковометодологічних засад формування і розвитку інноваційних структур в аграрній сфері та розробка практичних рекомендацій щодо підвищення ефективності їх діяльності. Для досягнення поставленої мети вирішуються такі завдання:

1. Визначити основні відмітності між видами інноваційних структур в залежності від їх функціонального призначення.

2. Виокремити основні напрями діяльності інноваційних структур, визначити їх статус і відповідні економічні відносини з державою й 
Якобчук В. П., Кащук К.М.

іншими суб'єктами господарювання.

3. Обгрунтувати можливості створення агроінноваційних структур в Поліському регіоні.

Об'єкти та методика дослідження. Об'єктом дослідження є процес формування і розвитку агроінноваційних структур в Україні в цілому та Поліському регіоні. Теоретичною та методологічною основою дослідження $\epsilon$ діалектичний підхід, наукові розробки, досвід міжнародних організацій у створенні та розвитку інноваційних структур.

Результати досліджень. Процеси глобалізації світової економіки посилили конкуренцію як на світовому, так і на національних ринках. У цих умовах дієвим інструментом підвищення конкурентоспроможності підприємств $є$ інноваційна модель їх розвитку. Саме посилення інтеграції науки 3 виробництвом, широке впровадження наукових досягнень у практику роботи суб'єктів господарювання є важливою умовою їх розвитку та підвищення ефективності функціонування.

Державні органи створюють основу, платформу для нововведень через прийняття законів та інших нормативно-правових рішень, проте провідна роль у побудові інноваційної моделі економіки належить регіонам, де підприємства, установи, організації та місцеві органи влади, мають можливості для активної співпраці та координації своїх дій. Американські дослідники стверджують, що регіони - це своєрідні блоки національної інноваційної місткості [8]. Кожен регіон у країні має свій потенціал, щоб стати інноваційним центром у властивому йому виді діяльності.

На сьогодні одним $з$ перспективних напрямів розвитку регіонів є створення інноваційних структур різних видів - наукових парків, технопарків, інноваційних кластерів. Ще в 1956 році при Стенфордському університеті створено перший науково-технологічний парк (кластер), який перетворив Кремнієву долину 3 одного 3 найбідніших регіонів у Сполучених Штатах на світовий центр технологій, фінансів і досліджень. Відтоді високотехнологічний кластерний феномен Силіконової долини став об'єктом дослідження науковців багатьох країн. Сотні подібних високотехнологічних кластерів створилося у різних частинах світу, i їх кількість продовжує зростати, оскільки кластерні утворення $\epsilon$ загальноприйнятим інструментом економічного розвитку та сполучною ланкою національної та регіональної інноваційних систем.

Проаналізувавши історію створення різних видів інноваційних структур, можна зробити висновок, що вони беруть свій початок від загально-регіональних інноваційних кластерів і, як показує наш аналіз, в процесі своєї еволюції трансформуються у вузькоспеціалізовані галузеві інноваційні утворення. (Табл. 1).

Подальша кластеризація сфер економічної діяльності призводить до формування науковотехнологічних парків (Science and Technology Park), як виду інноваційного кластеру, які почали створюватися з метою просування національних можливостей розвитку науки та технологій по всьому світі. Кожна міжнародна організація, що стимулює розвиток інноваційного підприємництва, уточнює його категоріальний апарат. Офіційне визначення, наукового парку прийняте Міжнародною асоціацією наукових парків у лютому 2002 року таке: "науковий парк організація, керована фахівцями 3 метою підвищення ефективності діяльності своїх партнерів шляхом впровадження культури інновацій і підвищення конкурентоспроможності супутніх підприємств і установ, заснованих на знаннях" [10]. Для досягнення цих цілей науковий парк стимулює та управляє потоками знань та технологій між університетами, науководослідними організаціями, компаніями та ринками; він спрощує створення та зростання інноваційно спрямованих компаній через інкубацію та спін-оф процеси та забезпечує інші послуги зі створення доданої вартості 3 наданням приміщень i можливостей. Вираз "науковий парк" ототожнюється цією організацією з такими видами інноваційного підприємництва, як "технологічний парк", "технополіс" або "дослідний парк".

Американська організація університетських дослідних парків визначає дослідний парк як високотехнологічну компанію, що надає послуги конструктивних, формальних та оперативних відносин з одним чи більше навчальних закладів, сприяє просуванню наукових досліджень у виробництво, допомагає створювати нові ризиковані підприємства, здійснює трансфер технологій та підприємницьких умінь між університетами та виробництвом, прискорює економічний розвиток міста та регіону [11].

Виходячи 3 вищевикладеного, можна стверджувати, що термін "науково-технологічний парк" ототожнюється з будь-яким видом науковотехнологічного кластеру, як наприклад: технополіс, науковий парк, наукоград, кіберпарк, високотехнологічний (індустріальний парк), інноваційний центр, науково-дослідний парк, університетський дослідний парк, досліднотехнологічний парк, наукове місто (science city/ town), технологічний парк, технологічний інкубатор, технопарк, технологічний бізнесінкубатор, кластер малих фірм (small enterprises clusters), індустріальні райони (industrial districts). Однак зауважимо, що різниця між деякими з цих термінів все ж існує. Цю різницю визначають такі 


\section{Етапи кластеризації}

\begin{tabular}{|c|c|c|}
\hline \$ี & Вид кластер & Основні ознаки \\
\hline 1 & Галузевий кластер & $\begin{array}{l}\text { Кластер розглядається як об’єднанням підприємств і організацій } \\
\text { однієї галузі. Даний етап в Україні з’явився здебільшого як } \\
\text { захисна реакція на відкриття торговельних кордонів і появу } \\
\text { іноземних конкурентів на внутрішньому ринку. }\end{array}$ \\
\hline 2 & $\begin{array}{l}\text { Технологічний } \\
\text { кластер }\end{array}$ & $\begin{array}{l}\text { Кластер - це об’ єднання підприємств і організацій, що входять в } \\
\text { один технологічний ланцюжок. Сучасна економіка здебільшого } \\
\text { функціонує за принципом технологічних кластерів. Особливу } \\
\text { увагу необхідно приділити впливу технологічних кластерів на } \\
\text { інноваційну діяльність компаній. Компанії усередині кластера не } \\
\text { тільки краще уявляють собі потреби локального ринку, але } \\
\text { завдяки тісним зв’язкам з іншими кластерними компаніями } \\
\text { швидше дізнаються про нові технології, наявність нового } \\
\text { устаткування, нові концепції послуг і маркетингу. З’являється } \\
\text { можливість координації зусиль і фінансових коштів виробників і } \\
\text { постачальників у процесі фіналізації нових технологій і виходу їх } \\
\text { на ринок. }\end{array}$ \\
\hline 3 & $\begin{array}{l}\text { Інноваційний } \\
\text { кластер }\end{array}$ & $\begin{array}{l}\text { Інноваційний кластер - це цілісна система підприємств і } \\
\text { організацій з виробництва готового інноваційного продукту, що } \\
\text { включає в себе весь інноваційний ланцюжок від розвитку } \\
\text { фундаментальної наукової ідеї до виробництва і дистрибуції } \\
\text { готової продукції. Він формує певну систему розповсюдження } \\
\text { нових знань і технологій, забезпечує прискорення процесу } \\
\text { трансформації винаходів в інновації, а інновацій - у конкурентні } \\
\text { переваги, розвиток якісних стійких зв’язків між всіма його } \\
\text { учасниками. Виникнення таких кластерів - закономірний процес } \\
\text { за наявності спільної наукової та виробничої бази. }\end{array}$ \\
\hline 4 & $\begin{array}{l}\text { Агротехнологічний } \\
\text { кластер }\end{array}$ & $\begin{array}{l}\text { Кластер об’єднує організації аграрного спрямування (компанії, } \\
\text { дослідницькі центри, органи державної влади, навчальні заклади), } \\
\text { які комплексно генерують агроінновації, комерціалізують їх }\end{array}$ \\
\hline
\end{tabular}

Джерело: власні дослідження, адаптовано [9, с. 206] 
Якобчук В. П., Кашук К.М.

фактори: орієнтація (наука, технології, інновації), спеціалізація (галузь народного господарства), розмір території (регіональне, національні), історія створення (Рис.1).

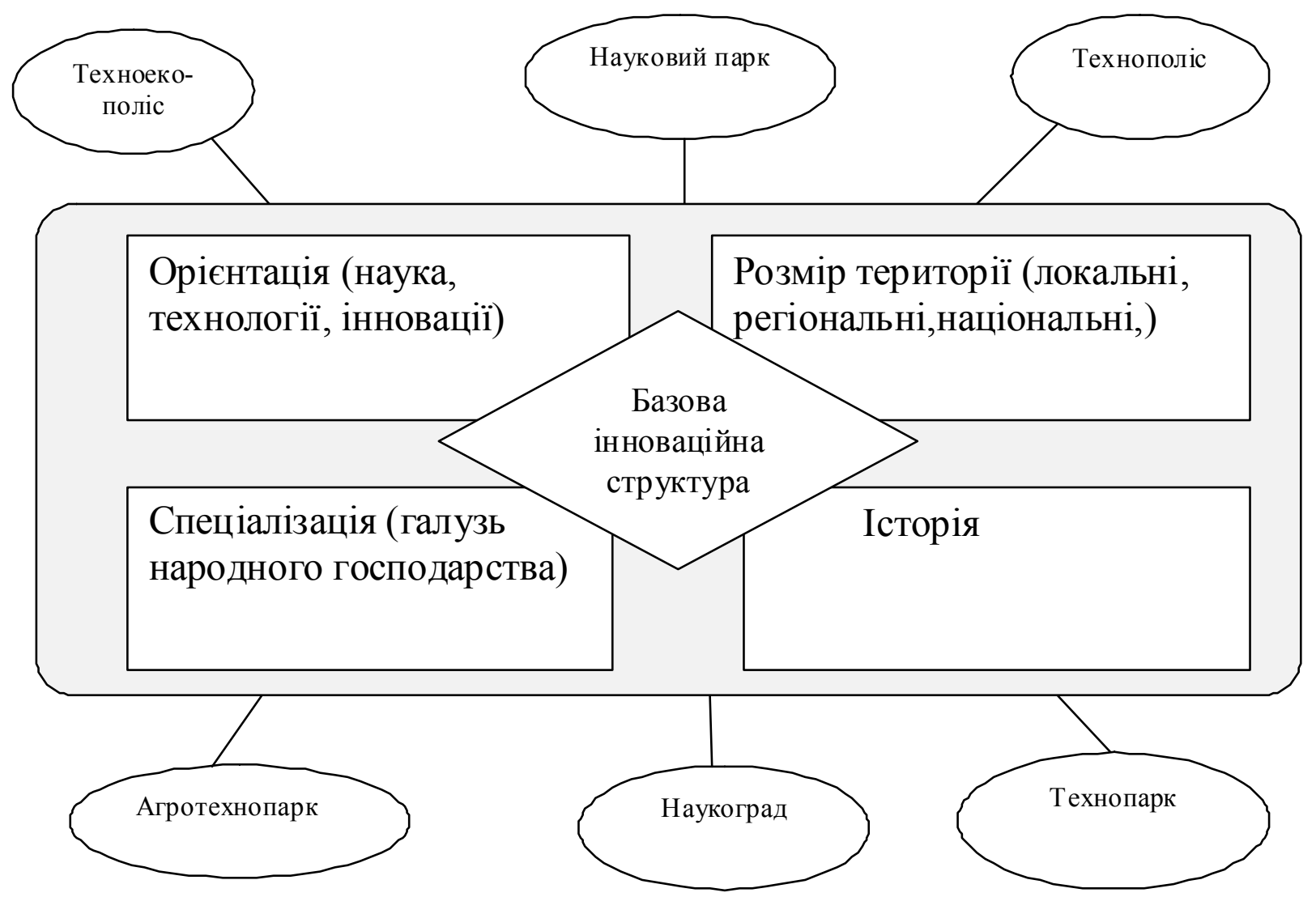

Джерело: власні дослідження

Відповідно до особливостей спеціалізації ми обгрунтовуємо можливість виокремлення аграрних парків (агротехнопарків), упровадження яких $\epsilon$ необхідною умовою для застосування новітніх технологій в сільськогосподарському виробництві та поєднання науки й аграрного виробництва. Потреба у створенні таких парків викликана підвищеним ступенем ризикованості сільськогосподарського виробництва як об'єкта інвестування. Так, в умовах кризи погіршення фінансового стану аграрних підприємств спричинює складність у залученні приватних інвестицій, які є основою для інноваційних зрушень в аграрному секторі, у зв'язку з чим частка сільського господарства в структурі інвестицій в основний капітал в порівнянні з іншими галузями зменшується. Динаміка інвестицій в основний капітал сільського господарства України подана в табл.2 (млн. грн.).

Як напрями розвитку інноваційного процесу в аграрній сфері необхідно також реалізувати можливості залучення іноземного капіталу; сприяти створенню малих підприємств у науковотехнічному середовищі; активізувати впровадження технологічних інновацій за допомогою проведення цілеспрямованої цінової політики, орієнтованої на кінцевого агровиробника. Підвищення конкурентоспроможності аграрних підприємств в Україні повинно базуватися на заходах державної підтримки, які б ліквідували економічні i адміністративні перешкоди впровадження досягнень науково-технологічного прогресу, створили сприятливі фінансовоекономічні умови розвитку інновацій в аграрній сфері, забезпечили притік інвестицій.

Для аналізу сучасного стану інноваційної діяльності підприємств АПК Житомирського області розглянемо дані інвестицій наведені в табл. 3. Підприємства Житомирського області в процесі своєї діяльності здійснюють капіталовкладення головним чином за рахунок власних коштів, не залучаючи зовнішні інвестиції, що не дає можливості повністю задовольнити всі їх потреби в фінансових ресурсах для інноваційного розвитку. Як видно 3 табл. 3, всього у 2010 р. обсяг інвестицій в підприємства АПК становив 28 417,3 тис. грн., 3 них за рахунок власних коштів - 19 961,6 тис. грн., коштів іноземних інвесторів вкладено взагалі не було. 
Динаміка інвестицій в основний капітал сільського господарства України

\begin{tabular}{|c|l|l|l|l|l|l|}
\hline Показники & 2001 p. & 2005 p. & 2007 p. & 2008 p. & 2009 p. & $\begin{array}{l}2009 \text { р. в \% } \\
\text { до 2008p. }\end{array}$ \\
\hline $\begin{array}{c}\text { Загальні обсяги } \\
\text { інвестицій в основний капітал } \\
\text { за всіма видами економічної } \\
\text { діяльності, млн. грн. }\end{array}$ & 32573 & 93096 & 188486 & 233081 & 151776,8 & 65,12 \\
\hline $\begin{array}{c}\text { Інвестиції в основний } \\
\text { капітал сільського } \\
\text { господарства, мисливства та } \\
\text { пов’язаних з ними послуг, } \\
\text { млн. грн. }\end{array}$ & 1552 & 4905 & 9338 & 16682 & 9381,7 & 56,24 \\
\hline $\begin{array}{c}\text { Частка сільського } \\
\text { господарства в структурі } \\
\text { інвестицій в основний } \\
\text { капітал, \% }\end{array}$ & 4,8 & 5,3 & 5,0 & 7,1 & 6,2 & $-0,9$ п.п. \\
\hline
\end{tabular}

Джерело: розраховано за даними Держкомстату України [12].

Таблиия 3

Джерела фінансування інноваційної діяльності АПК в Житомирській області, тис. грн.

\begin{tabular}{|l|l|l|l|l|l|}
\hline \multirow{2}{*}{ Рік } & \multirow{2}{*}{$\begin{array}{l}\text { Загальна } \\
\text { сума } \\
\text { витрат }\end{array}$} & \multicolumn{5}{|c|}{ У тому числі за рахунок коштів } \\
\cline { 3 - 6 } & власних & $\begin{array}{l}\text { державного } \\
\text { бюджету }\end{array}$ & $\begin{array}{l}\text { іноземних } \\
\text { інвесторів }\end{array}$ & інші джерела \\
\hline 2001 & 27171,0 & 19152,7 & 13,0 & - & 8005,3 \\
\hline 2005 & 46797,1 & 43692,7 & - & 349,0 & 2755,4 \\
\hline 2007 & 61366,3 & 47867,3 & - & - & 13499,0 \\
\hline 2008 & 48563,7 & 28585,6 & 4115,0 & - & 15863,1 \\
\hline 2009 & 44674,3 & 43777,0 & 145,0 & - & 752,3 \\
\hline 2010 & 28417,3 & 19961,6 & 2080,7 & - & 6375,0 \\
\hline
\end{tabular}

Джерело: дані Держкомстату України [12].

Тому для поліпшення інвестиційного клімату в сільському господарстві Житомирщини, підвищення конкурентоспроможності підприємств АПК як окремого регіону, так і країни в цілому ми пропонуємо створювати диверсифіковані агроінноваційні структури 3 урахуванням досягнутого науково-інноваційного потенціалу регіону, рівня господарювання території, специфіки розвитку окремих сфер аграрної діяльності. Узагальнюючи аналіз різних організаційних структур інноваційного процесу, можемо стверджувати, що сучасна агроінноваційна структура $є$ галузевим диверсифікованим науковотехнічним комплексом юридично і економічно

самостійних, функціонально об'єднаних наукових, проектно-конструкторських, інформаційних, фінансових, технологічних закладів та аграрних підприємств, діяльність яких спрямована на оновлення, впровадження та реалізацію нововведень.

При створенні агроінноваційних структур, зокрема агротехнопарків, необхідно враховувати науковий потенціал, напрацьований ученими університетів й ринкові потреби виробництва того чи іншого продукту у регіоні розміщення агроформувань. 3 огляду це, на сьогодні ми обгрунтовуємо необхідність створення диверсифікованої агроінноваційної структури на 
Якобчук В. П., Кашук К.М.

базі флагману аграрної науки в регіоні Житомирського національного агроекологічного університету. У його структурі 8 факультетів, Науково-дослідний інститут регіональних екологічних проблем, Інститут післядипломної освіти та дорадництва, навчально-дослідне господарство "Україна", дослідне поле, ботанічний сад, навчально-ветеринарна клініка, Будівельний коледж Житомирського національного агроекологічного університету та Технікум землевпорядкування Житомирського національного агроекологічного університету. Університет є провідним вищим аграрним закладом екологічного спрямування, центром науки, культури в регіоні і має всі можливості для того, щоб стати ключовою ланкою в системі "наука-виробництво".

Висновки та перспективи подальших досліджень. Проведений аналіз існуючих видів інноваційних структур у провідних країнах ринкової економіки свідчить про те, що їх вибір в кожному окремому випадку визначається конкурентними перевагами регіонів, історією створення, напрямами досліджень та спеціалізацією. Місцева влада, підприємці та науковці регіонів мають поєднати свої зусилля для заснування науковотехнологічних парків, щоб створити додатковий синергетичний ефект від кооперації науки та виробництва i, таким чином, провести ребрендинг своїх регіонів, поставивши стратегію свого розвитку у відповідність технологічній революції та глобальній економіці. Доцільно розробити державну програму організації та фінансового стимулювання наукових парків та інноваційних структур інших типів, оскільки нинішні темпи їх створення не відповідають інтересам України. Цю програму варто розробляти спільно із зацікавленими міністерствами, щоб забезпечити створення регіональних інноваційних мереж в Україні 3 використанням вітчизняного та закордонного досвіду. Створення агротехнопарків та інших видів агроінноваційних структур в Україні $\epsilon$ одним 3 пріоритетних напрямів розвитку національної економіки. Нові форми підприємництва в АПК здатні надати вагомі інноваційні імпульси в загальну економічну політику держави.

\section{Список літератури}

1. Андриянов В. Научные парки. Юго-восточный вариант / В. Андриянов // Внешняя торговля. - 1990. №9. - С. 33-35.

2. Иванов М.М. США: Управление наукой и нововведениями / М.М. Иванов, С.Р. Колупаев . - М. : Изд-во "Наука", 1990. - 231 с.

3. Каратаев А. Научные парки развитых капиталистических стран. Внешняя торговля /А. Каратаев. - 1990. - № 9. - С. 13-15.

4. Васенко В.К. Вільні економічні зони: стратегія розвитку : монографія / В.К. Васенко. - Суми : Вид-во "Довкілля", 2004. - 348 с.

5. Мазур О.А. Технологічні парки. Світовий та український досвід / О.А. Мазур, В.С. Шовкалюк. - К. : Вид-во "Прок-бизнес", 2009. - 70 с.

6. Семиноженко В. Технологічні парки в Україні: перший досвід формування інноваційної економіки / В. Семиноженко // Економіка України. - 2004. - № 1. -C. 6.

7. Технологічні парки. Світовий та український досвід / за ред. Д.В. Табачника. - К. : Вид-во Тп IЕЗ, 2004. - 48 c.

8. Інноваційна діяльність в системі кластерних утворень: МатеріалиVII Всеукраїнської науковопрактичної конференції ["Міжнародне науковотехнічне співробітництво: принципи, механізми, ефективність"], (Київ, 10-11 березня 2011 р.). / М-во освіти і науки України, Національний технічний університет України "Київський політехнічний інституг". - К.: НТУУ "КПІ", 2011. - 298с

9. Перспективи впровадження інноваційних кластерів в умовах побудови економіки знань в Україні [Електронний ресурс] / Т. М. Корнєєва // Вісник Хмельницького національного університету. - 2009. ? №3. - Т2. - С. 206. - Режим доступу до журн.: http://nbuv.gov.ua/portal/Soc_Gum/Vchnu_ekon/ $200932 /$ pdf $/ 205-210 . p d f$

10. Н Наукові парки: суть, функції та перспективи створення [Електронний ресурс] / І. Б. Чудаєва // Науковий вісник НЛТУ України. - 2011. ? Вип. 21.1. C. 360. ? Режим доступу до журн.: http:// www.nbuv.gov.ua/portal/chem_biol/nvnltu/21_1/ 352_Czud.pdf

11. Official site of United Nations Educational, Scientific and Cultural Organization http:// www.unesco.org/new/en/natural-sciences/sciencetechnology/university-industry-partnerships/sciencetechnology-park-governance/concept-and-definition/

12. Інвестиції в основний капітал сільського господарства в динаміці. - офіційний сайт Державного комітету статистики України режим доступу: www.ukrstat.gov.ua 


\section{ФОРМИРОВАНИЕ И РАЗВИТИЕ АГРОИННОВАЦИОННЫХ СТРУКТУР В УКРАИНЕ: ПРОБЛЕМЫ И ПЕРСПЕКТИВЫ}

Рассмотрены научно-методологические основы формирования и развития инновачионных структур в аграрной сфере. Определены основные различия между видами инновационных структур в зависимости от их функиионального предназначения. Обоснованы возможности создания агроинновачионных структур в Полесском регионе.

Ключевые слова: научный парк, исследовательский парк, бизнес-инкубатор, инновационный цеентр, научный потенциал, диверсификация, нововведение, агроинновационная структура.

\section{Summary}

Valentyna Yakobchuck, Kateryna Kaschuck

\section{FORMATION AND DEVELOPMENT OF AGROINNOVATIVE STRUCTURES IN UKRAINE: PROBLEMS AND PERSPECTIVES}

The paper focuses on scientific and methodological foundations of innovative structures' formation and development in agrarian sphere. It also determines the main differences between types of innovative structures depending on their intended purposes. The possibilities of creating agroinnovative structures in Polissya region are substantiated.

Key words: science park, research park, bisness-incubator, innovative center, science potential, diversification, novation, agroinnovative structure. 


\title{
МІЖНАРОДНА ЕКОНОМІКА
}

\author{
УДК 339.5 \\ () Михайлина Д. Г., 2011 \\ Чернівецький національний університет імені Юрія Федьковича, м. Чернівці
}

\section{СУЧАСНІ ІМПЕРАТИВИ ОРГАНІЗАЦЙНОӦ РЕСТРУКТУРИЗАЦІЇ МІЖНАРОДНИХ КОРПОРАЦЙ}

Досліджено основні зрушення у сучасних підходах до розробки ефективних організаційних структур згідно глобальних імператив корпорачійного розвитку. Окреслено ключові тенденції управлінсько-організаційної реструктуризачії міжнародних корпорачій, враховуючи вагомі глобальні трансформації у загальногосподарському та галузевому розрізі, що визначають доиільність та напрямки змін управлінських моделей.

Ключові слова: глобальні трансформачї̈, інтрапренерство, корпораційна організаційна структура, реструктуризаџія, транснаціональна корпорація, управління.

Постановка проблеми. Сьогодні особливого значення набуває питання становлення новітніх організаційних підходів в рамках корпоративного глобалізму та їхній безпосередній вплив на розвиток управлінського досвіду в конкретних національних економіках. Саме організація, за думкою вчених-економістів, "виступає базовим процесом, що протистоїть росту втрат i, відповідно, забезпечує ефективність накопичення" [10, c. 54].

Завдяки росту й еволюції корпорацій поступово вибудовується міцна економічна система, яку завершує цілісна система управління. Виходячи із закономірностей сучасного світогосподарського розвитку, з метою пізнання особл=ивостей функціонування глобальної економічної системи, необхідно поєднувати традиційну макроекономічну позицію 3 мікроекономічною перспективою транснаціональних корпорацій.

Аналіз останніх досліджень і публікацій. Протягом останніх років проблемі пошуку адекватної управлінської моделі у сфері глобального корпоративного менеджменту присвячено досить багато праць як зарубіжних, так і вітчизняних авторів, серед яких варто виділити таких науковців, як О.Білорус, М.Данько, В.Вутянов, Р.Зименков, Ю.Кочервин, Н.Іванова, А.Мовсесян, Н.Розанова, І.Трофимова, Ч.Бартлет,
С.Гошал, а також ряд інших авторів, які зосереджують свою увагу на конкретних особливостях організації управління корпоративних структур в умовах сучасних глобальних трансформацій.

Нерозв'язані раніше частини загальної проблеми. Питання організації управління та їхній зв'язок з ефективністю не $є$ новими у дослідженні діяльності крупних міжнародних корпорацій. Проте сьогодні спостерігаються деякі новітні зрушення у підходах до розробки ефективних організаційних структур копорацій. У рамках таких зрушень спостерігаються дві ключові взаємопов'язані тенденції. 3 одного боку поглиблюється економічна транснаціоналізація, а з іншого боку, в рамках постіндустріального укладу, оформлюються контури геоекономічного світоустрою, носіями якого залишаються потужні корпорації, що відкриває нові горизонти у дослідженні розробки чи реформування ефективних організаційних структур.

3 цього приводу А.І.Неклесса зауважує, що "у новому світоутворенні правлять бал його впливові суб'єкти - еліта домінуючої "геоекономічної корпорації"... Вони цілеспрямовано вдосконалюють свою подобу, скидаючи "стару шкіру" - застаріваючі та малоефективні галузі виробництва" [7, с. 14]. Згідно зі статистичними 
даними ЮНКТАД за 2009 р., зафіксовано 82,000 ТНК по світу та 810,000 філіалів, відповідно, що й надалі охоплюють понад третину світовго експорту. Проте, незважаючи на свій гнучкий інтернаціональний характер, ці корпоративні структури також зазнали впливу світових кризових процесів, що призвело до загального зниження доходів приблизно на 4,8\% [12].

Постановка завдання. Така ситуація актуалізує проблему пошуку найбільш адекватних моделей організації управління в умовах сучасних глобальних трансформацій. Зокрема, внаслідок кризових явищ, найбільше постраждали компанії автомобільної промисловості, у результаті чого вони змушені були переглянути свої організаційні структури, окремі модельні ряди, інвестувати у нові покоління силових установок (гібридні, чисто електричні, із застосуванням водневих паливних елементів). Щоправда, багато галузевих експертів стверджують, що головна проблема глобального автомобілебудування - не технологія, а надлишок виробничих потужностей, тому не уникнути реструктуризації, внаслідок якої у світі залишиться усього 5-6 компаній 3 обсягом продажів не менше 5,5 млн. автомобілів на рік [5, c. 29].

Подібна ситуація склалася й у фармацевтичній галузі, компанії якої також зреагували зміною своїх бізнес-моделей, передовсім за рахунок капіталовкладень у біотехнології, придбання підрозділів із виробництва дженеріків і вакцин, а також скорочення персоналу. Подібні вагомі структурні зрушення відбулися також й у секторі інформаційно-телекомунікаційних технологій (Yahoo, Microsoft) і навіть у авіакосмічній галузі (Boeing) [5, с. 31]. Враховуючи вищенаведені тенденції, метою даної статті є визначення оптимальних напрямків модифікації організаційних структур згідно сучасних глобальних імператив корпораційного розвитку.

Викладення основного матеріалу дослідження. Серед ключових зрушень у процесі управлінськоорганізаційної реструктуризації міжнародних корпораційних структур слід виділити наступні:

- домінування моделі внутрішньофірмового підприємництва, що передбачає самостійну управлінську роботу окремих підрозділів, зменшення їхніх розмірів 3 метою вузької спеціалізації та надання їм більшої гнучкості;

- дебюрократизація, відмова від формалізації, встановлення відносин партнерства на противагу ієрархічним відносинам;

- використання гнучких форм управління i відмова від матричних рамок;

- організація "горизонтальних" ТНК і виникнення різноманітних мережевих структур управління; трансформація організаційних структур компаній з пірамідальних у пласкі;

- залучення зарубіжних філіалів до розробки

та освоєння передових технологій;

- зростання значення інтелектуальних активів та інновацій;

- застосування стратегії "глибокої інтеграції" на зміну стратегії "діяти самостійно";

- управління у формі "бізнес-одиниць", які самі несуть повну відповідальність за свою діяльність;

- створення автономних груп (команд);

- організація спеціальних проміжних компаній;

- зміна стратегії "диверсифікації товару" на стратегію "фокусування на ядрі";

- зростання значення малих та середніх ТНК, особливо у високотехнологічних галузях;

- зростання ваги топ-менеджерів і спеціалістів у володінні капіталом та прийнятті стратегічних рішень з розвитку і управління корпорацією.

В умовах глобальних трансформацій провідні ТНК поєднують використання гнучких форм управління і транснаціональної підприємницької діяльності, що забезпечують економічну доцільність їхньої структурної та інвестиційної політики. Ключовою в сучасній практиці діяльності ТНК стала проблема переходу від застарілої бюрократичної (механічної) моделі управління підприємством до органічної моделі або інтрапренерства. Бюрократична модель свого часу була справді ефективною в умовах стабільного зовнішнього середовища, масового виробництва стандартизованої продукції, незначної уваги до інновацій. Прикладом успішного застосування централізованої моделі управління підприємством Ф.Тейлора $\epsilon$ діяльність американських автомобільних заводів Генрі Форда-I, що свого часу показало блискучі результати. Нині саме компанія "Форд" випереджає своїх конкурентів завдяки застосуванню практично протилежної моделі "внутрішньофірмового підприємництва" 3 делегуванням прав самостійної роботи окремим підрозділам.

До розповсюджених у 90-ті роки форм управління головною компанією своїми зарубіжними філіалами відноситься так звана матриця у трьох вимірах. Організаційна структура у формі матриці передбачає неформальну організацію управління, при якій кожний менеджер зарубіжного філіалу має у головній компанії двох керівників - по лінії виробництва відповідного виду продукції і по лінії управління регіоном, у який входить країна розміщення його підприємства. Прогнозуючи подальший розвиток структури управління міжнародними компаніями, професор Гарвардської школи бізнесу К.Бартлетт і 
Михайлина Д. Г.

професор Європейського інституту адміністрації бізнесу С.Гошал у дослідженні "Багатонаціональна корпорація як інтер-організаційна мережа" приходять до висновку, що ускладнення та диверсифікація міжнародного підприємництва останніми десятиліттями досягли такої стадії, коли "управління багатонаціональними підприємствами повинно буди надзвичайно чутливим та гнучким, не скутим рамками матриць" [11, с. 70].

Сучасний етап розвитку виробничих взаємовідносин головних компаній із зарубіжними філіалами характеризується здебільшого комплексною інтеграцією на регіональному чи глобальному рівні. При цьому має місце інтеграція зарубіжного філіалу у світогосподарську діяльність головної компанії зі складною системою усіх видів зовнішньоекономічних зв'язків на базі спеціалізації виробництва і надання послуг філіалом. Зв'язок 3 головною компанією здійснюється 3 використанням інформаційних технологій. Продукція філіалу експортується у різні країни, включаючи країну головної компаніі. Укріплюються зовнішньоекономічні зв'язки філіалу з іншими зарубіжними підприємствами ТНК на базі субконтрактів, ліцензійних угод, консорціумів, альянсів. 3 керівництвом ТНК у філіалу встановлюються відносини партнерства, a не ієрархії. Причому, чим більш ефективна та прибуткова діяльність зарубіжного філіалу, тим більше самостійності йому надає головна компанія.

Системна інтеграція сьогодні вважається ефективним напрямком організації бізнесу у сфері інформаційних технологій, за якої головна фірма поєднується із замовником (промисловою, торговельною чи фінансовою компанією) в єдиний виробничий ланцюг, що забезпечує перехід від короткострокових (на період реалізації конкретного проекту) відносин до довготривалих, що охоплюють увесь цикл обслуговування i реінжинірингу [9, с. 76].

У 90-ті рр. намітилася тенденція організації спеціальних проміжних компаній, які на контрактній основі передають частину своїх підприємницьких функцій, передовсім виробничих, підрядникам 3 інших країн. Отже, формується організаційна структура, у якій усі виробничі функції виконує субпідрядник, а координує їхню діяльність проміжна фірма.

Головна компанія здійснює управління усім процесом - від розробки ідеї товару до продажу його кінцевому споживачеві. У цьому випадку ТНК займається просуванням товару під своєю торговою маркою, не займаючись його виробництвом. У проміжній же компаній працює велика кількість висококваліфікованих спеціалістів-менеджерів, які організують роботу іноземних підрядних підприємств. Останнім ТНК передає усі функції зі створення товару, окрім упакування. Незалежні підприємства за кордоном у якості підрядників за замовленнями проміжної фірми розробляють і виробляють необхідні товари.

Проміжні компанії отримали розповсюдження передовсім у галузях, що зайняті виробництвом споживчих товарів: дитячих іграшок, одягу, взуття, товарів для спорту, у меншому ступені - побутової та комп'ютерної техніки. Така форма організації й управління використовується, зокрема, французькими ТНК, що дозволяє їм виробляти конкурентоспроможну продукцію без витрат засобів на створення заводів. У цьому випадку головна компанія виступає у якості дослідницької, дизайнерської та маркетингової компанії, що вкладає капітал у рекламу, а не у виробництво. Решта функцій надається проміжним фірмам.

Такий підхід дає очевидну перевагу перед традиційними вертикально-інтегрованими монополіями, які перевантажені численними рівнями управління та контролю своїх підрозділів. Однак тут має місце і ряд негативних наслідків. Передовсім це пов'язано 3 високим ступенем залежності їхньої діяльності від зміни кон'юнктури. Проміжна компанія не здатна забезпечити контроль за якістю продукції, що випускається. Основною ж проблемою є нестійкий і ненадійний зв'язок головної компанії зі своїми виробниками: підприємства-субпідрядники у випадку успіху можуть у будь-який момент відмовитися від торгової марки головної компанії й вже без посередництва проміжних фірм укласти угоди щодо продажу своєї продукції споживачам за нижчими цінами [2, с. 110-111].

Тим не менше, сьогодні зростає значення малих та середніх ТНК, особливо у високотехнологічних галузях, де основний дохід підприємствам дає інтелектуальний капітал. Власники цього капіталу - топ-менеджери i спеціалісти набувають усе більшої ваги, часто відтісняючи титульних власників при прийнятті стратегічних рішень 3 розвитку й управління корпорацією. Сьогодні 15 з 20 найбагатших людей США представляють компанії, що виникли протягом останніх десятиліть ("Microsoft", "Metromedia", "Dell", "Intel", "Oracle", "Viacom", "New World Communications"). Ці компанії завдячують своїм феноменальним злетом одному чи декільком людям - їхнім засновникам i власникам, що не втрачають контролю над ними.

Сьогодні у США формується принципово новий вид ТНК, орієнтований у першу чергу на діяльність у сфері послуг та інформаційних технологій. Їхні прямі зарубіжні інвестиції здійснюються у сферу послуг і носять глобальний характер. Ці корпорації 
передають виробництво у відповідності 3 системою угод іншим компаніям, нерідко у країнах, що розвиваються, а самі концентрують свою діяльність на НДДКР. Крім того, вони активно співпрацюють одне 3 одним у рамках міжнародних стратегічних альянсів.

Глобальні компанії вже зараз формують механізми взаємодії з малими фірмами у сфері НДДКР. Деякі з них (General Electric, Cisco) вже досягли у цьому певних успіхів, інші ("Procter \& Gamble") здійснюють великі інвестиції у власні НДДКР. У перспективі можливе формування "горизонтальних корпорацій", специфіку яких складає обмеження ієрархії, а деколи й повна відмова від неї. Оргструктура заснована на розділенні по базових процесах (як правило виділяють 3-5 процесів, що лежать в основі виробничого циклу). Основу компанії складають автономні робочі групи (команди), кількість яких також мінімізується. Топ-менеджмент вкрай нечисленний, у його розпорядженні залишаються лише фінанси і кадри.

Наприклад, "АТ\&T" сформувала автономні групи численністю від 10 до 15 осіб і скоротила число базисних процесів зі 130 до 13. General Electric, що також почала перехід до нової системи у 90-х роках, до цих пір зберігає до 100 базисних процесів, у рамках яких функціонують групи чисельністю від 9 до 12 осіб [6, с. 57].

Певні зрушення відбулися й у стратегічних підходах ТНК продовольчого сектору. Якщо основною концепцією стратегічного розвитку продовольчих ТНК у 80-ті рр. й у першій половині 90-х рр. була диверсифікація товару і функцій, то у кінці XX - на початку XXI ст. їі змінила концепція спеціалізації, що виражається стратегією "фокусування на ядрі". Така стратегія передбачає виділення основної сфери діяльності й концентрацію зусиль на цьому генеральному напрямку, що означає підвищення ступеня спеціалізації на рівні товару, галузі, функції. Численні різновиди стратегіi "фокусування на ядрі" інакше звуться концепціями реконфігурації. Так, відмовившись від діяльності у сфері громадського харчування й зосередивши пі виключно на виробництві й торгівлі упакованими продуктами та напоями, ТНК "РеpsiCo" подвоїла свій оборот, довівши його до 1,4 млрд. дол. [8, с. 7].

На сьогоднішній день перспективною формою господарювання у світовому сільськогосподарському секторі вважається укладання контрактів між ТНК та фермерськими підприємствами приймаючої країни, що дозволить останнім наростити свої потужності та стати вагомою ланкою національного чи інтернаціонального продовольчого сектору. ТНК також зацікавлені у такій формі кооперації, враховуючи специфіку продукування конкурентоспроможної сільськогосподарської культури в умовах нинішніх кризових явищ, а також можливості отримання державної підтримки [12].

Висновки та перспективи подальших досліджень. Завдяки ефективній модернізації управлінської структури, ТНК здобули таку ринкову владу, яка робить їх незалежними дійовими особами міжнародної економічної системи, зумовлюючи зміни в національних економіках і спонукаючи політичні дії у відповідь 3 боку урядів. Дослідження сучасних організаційних форм корпорацій та їхніх управлінських структур дає можливість констатувати той факт, що в сучасних умовах усе доцільніше застосування гнучкого, диверсифікованого, неодноманітного підходу. Попередній пошук універсальної концепції, ідеальної структури, адаптованої до будь-якої організації, заміщується прагненням створення багатоаспектної концепції, що характеризується відмовою від ідеї оптимальної моделі. У центрі уваги постає перехід до нової наукової моделі управління, що базується на корпораційних інтеграційних процесах, корпораційній консолідації у вигляді стратегічних альянсів та інших подібних об'єднань найрізноманітніших конфігурацій.

\section{Список літератури}

1. Білорус О. Глобалізація та глобальний менеджмент: аналіз і реальність сучасних концепцій / О.Білорус // Економічний часопис - XXI. - 2003. - № 9. - C. 3 - 7.

2. Вутянов В. Новые тенденции организации международного бизнеса французскими ТНК / В.Вутянов // Мировая экономика и международные отношения. - 2000. - № 9. - С. 110 - 111.

3. Данько М.С. Формування корпоративних структур в Україні / М.С.Данько // Економіка і прогнозування. - 2005. - № 4. - С. 50 - 66.

4. Зименков Р. Американские ТНК за рубежом: стратегия, направления, формы / Р.Зименков, Е.Романова // Мировая экономика и международные отношения. - 2004. - № 8. - С. 45 - 53.

5. Иванова Н. Антикризисные программы в инновационной сфере / Н.Иванова, И.Данилин // Мировая экономика и международные отношения. - 2010. - № 1. - С. 26 - 37.

6. Мовсесян А. Современные тенденции в развитии и управлении ТНК / А.Мовсесян, А.Либман // Проблемы теории и практики управления. - 2001. № 1 . - C. 54 - 59 .

7. Неклесса А.И. Эпилог истории / А.И.Неклесса / / Восток. - 1998. - № 5. - С. 5 - 30.

8. Ревенко Л.С. Транснациональные корпорации на мировом рынке продовольствия на современном этапе научно-технического прогресса / Л.С.Ревенко // БИКИ. - 2006. - № 4 (8950), 14 января. - С. 6 - 7.

9. Розанова Н. Информационные технологии: 
Михайлина Д. Г.

\begin{tabular}{|c|c|}
\hline $\begin{array}{l}\text { средство выживания или конкурентное } \\
\text { преимущество? / Н.Розанова // Мировая экономика } \\
\text { и международные отношения. - 2010. - № 7. - С. } 74 \text { - } \\
82 .\end{array}$ & $\begin{array}{l}\text { 11. Organization Theory and the Multinational } \\
\text { Corporation / [Edited by Sumantra Ghoshal and } \\
\text { D.Eleanor Westney]. - Second edition. - Palgrave } \\
\text { Macmillan. - 2005. - } 345 \text { p. }\end{array}$ \\
\hline $\begin{array}{l}\text { Трофимова И. Крупные корпорации и } \\
\text { эффективность экономики (организационный } \\
\text { подход) / И. Трофимова // Мировая экономика и } \\
\text { международные отношения. - 1992. - № 9. - С.53-67. }\end{array}$ & $\begin{array}{l}\text { 12. World Investment Report. Transnational } \\
\text { Corporations, Agricultural Production and } \\
\text { Development. -United Nations. New York and Geneva, } \\
2009 / \text { [електронний pecypc] // unctad.org/en/docs/ } \\
\text { wir2009 }\end{array}$ \\
\hline
\end{tabular}

Аннотация

Диана Михайлина

\section{СОВРЕМЕННЫЕ ИМПЕРАТИВЫ ОРГАНИЗАЦИОННОЙ РЕСТРУКТУРИЗАЦИИ МЕЖДУНАРОДНЫХ КОРПОРАЦИЙ}

Исследованы основные сдвиги в современных подходах к разработке эффективных организачионных структур соответственно с глобальными императивами корпорачионного развития. В статье исследованы основные сдвиги в современных подходах к разработке эффективных организационных структур соответственно с глобальными императивами корпорационного развития. Очерчены ключевые тенденции управленческо-организационной реструктуризачии международных корпораций, учитывая весомые глобальные трансформации в общехозяйственном и отраслевом разрезе, которые определяют целесообразность и направления изменений управленческих моделей.

Ключевые слова: глобальные трансформации, итрапренерство, корпоративная организационная структура, реструктуризация, транснациональная корпорация, управление.

\section{Summary}

Diana Mykhaylyna

\section{MODERN IMPERATIVES OF INTERNATIONAL CORPORATION ORGANIZATIONAL RESTRUCTURING}

The main shifts in modern approach to elaboration of the efficient organizational structure according to global imperatives of corporation development are researched in this article. The key trends in the management and organizational restructuring of international corporations, considering the significant global transformation in general economic and branch cut, that determine management models change expediency and directions are outlined.

Key words: global transformations, entrepreneurship, corporation organizational structure, restructuring, transnational corporation, management. 
УДК 339.727.2

(C) Фищук I. М., 2011

Київського національного університету імені Тараса Шевченка, м. Киӥв

\section{УКРАЇНСЬКІ КОМПАНІЇ НА МІЖНАРОДНИХ ФОНДОВИХ РИНКАХ}

Розглянено особливості первинного розміщення акцій (IPO) українських компаній в умовах глобалізації фондового ринку. Виявленоно, що публічна пропозиція інвесторам є одним із найпривабливіших способів залучення коштів, оскільки має низку переваг порівняно з кредитуванням та випуском облігачій.

Ключові слова: изінні папери, акції, інвестиції, фондовий ринок.

Постановка проблеми. IPO дає можливість вітчизняним компаніям вийти на новий рівень, досягти визнання 3 боку міжнародного ринку капіталу та зробити поштовх для подальшого розвитку бізнесу в Україні. залучити достатній обсяг додаткових капіталовкладень i не "продатися" стратегічним інвесторам. Проведення IPO як спосіб альтернативного фінансування є залучення додаткових інвестицій в акціонерний капітал компанії, тобто залучення суттєвого фінансового капіталу на довгостроковій основі. Це означає, що первинне розміщення цінних паперів $є$ альтернативою іншим способам залучення довгострокового капіталу на ринку, таким як випуск облігацій, одержання кредиту тощо. Первинне розміщення акцій підтверджує, що корпоративне управління в компанії відповідає прийнятому стандарту, досягнута інформаційна прозорість і компанія має довгострокову стратегію розвитку бізнесу

Дослідження та публікації $з$ даної тематики. Проблеми первинного публічного розміщення акцій присвячена значна кількість наукових праць у світовій та українській економічній літературі. Так, теоретичні підходи до аналізу цього явища розроблені у працях О. Л. Каніщенко, М. В. Сороки, Р. Агарвол та А. Люнгвіст, В. Гейця, В. Заруби, С. Ілляшенка, І. Закаряна, Н. Костенко, Н. Явтушенко, Н. Чухрай, Р. Задорожної, П. Гулькіна, О. Дагаєва, Р. Хофата та інших вченихекономістів. Разом з тим певні аспекти цієї наукової проблеми залишаються недостатньо розробленими. Необхідні подальші дослідження напрямків інтенсифікації роботи фондового ринку України.

Мета дослідження. Метою статті є аналіз альтернативних способів залучення фінансових ресурсів компаніями через здійснення операції IPO. У статті міститься обгрунтування поширення практики IPO серед українських підприємств як механізму залучення інвестицій компаніями у всьому світі.
Основний зміст дослідження. Первинне публічне розміщення акцій (IPO) - це проведений вперше процес відчуження акцій публічного акціонерного товариства на підставі повідомлення про продаж цінних паперів, зверненого до заздалегідь визначеного кола осіб, який зазвичай проводиться шляхом торгів на фондовій біржі.

Публічність IPO передбачає процедуру залучення широкого кола бажаючих інвесторів через співробітництво з міжнародними фондовими біржами. Публічність позначається на організаційно-процесуальних засадах продажу акцій: продавець (емітент) робить свою компанію максимально зрозумілою і відкритою для інвестора. Це передбачає прозоре інформаційне забезпечення, зокрема публікацію звітності, впровадження сучасних стандартів управління тощо. Після операцій IPO доводиться звикнути, що потрібно публікувати звітність, підтримувати високу прозорість компанії, упроваджувати сучасні стандарти управління. Адже, акції після розміщення залишаються на біржі, і щодня їхня вартість змінюється. Щоб уникнути падіння курсу, потрібно постійно підтримувати впевненість інвесторів в успішному майбутньому компанії. У разі приватного розміщення, навпаки, можна показувати звітність лише обмеженому колу власників, як до розміщення акцій, так і після. Нові тенденції розвитку світових фондових ринків не могли не позначитись на Україні, так початок процесів українських IPО почався в 2005 році одразу три українські компанії, що здійснили первинні розміщення акцій на Альтернативному торговельному майданчику Лондонської фондової біржі (AIM LSE), це компанія "Ukrproduct Group", яка у такий спосіб залучила 6 млн. англійських фунтів, компанія "Cardinal Resources", представник нафтового і газового сектора, випустила акцій на суму 10,6 млн. фунтів у квітні 2005 р. та однією із найвдаліших у 2005 р. був досвід здійснення IPO девелоперською компанією "XXI століття", яка за 
Фищук I. M

рахунок продажу акцій додаткової емісії розміром $35 \%$ статутного фонду залучила \$ 138,7 млн. англійських фунтів.

При IPO, навпаки, якщо компанія приваблива, попит на акції у багато разів перевищує їхню пропозицію, і ціна зростає. Якщо підходити до процесу стратегічно, то можна здійснити перше розміщення, продавши, наприклад, 10\% акцій. Після цього за рахунок зразкової поведінки i високих прибутків акції зростуть у ціні, і можна зробити IPO за вищою вартістю. Отже, на кожному етапі залучається максимальна кількість грошей [ , С. 327-335].

У результаті IPO формується так звана "business value" - вартість бізнесу, що розраховується як добуток загальної кількості акцій і ціни, за якою акції обертаються на фондовій біржі. У результаті створюється величина набагато більша, оскільки вартість бізнесу враховує не лише активи компанії, а й якість управління, торгову марку, в ціну закладаються перспективи розвитку компанії та інші параметри. Нові акціонери платять за акції кошти, від яких планують отримувати доходи у вигляді дивідендів і курсової різниці (поступового зростання вартості цінного паперу). Але інвестори не вимагають від компанії повертати свої вкладення невдовзі, як це буває при кредитуванні чи випуску єврооблігацій. На рисунку 1 показано можливі цілі та напрямки при здійсненні IPO, що включає в себе: залучення нового акціонерного капіталу в компанію, капіталізація компанії, захист від можливого поглинання.

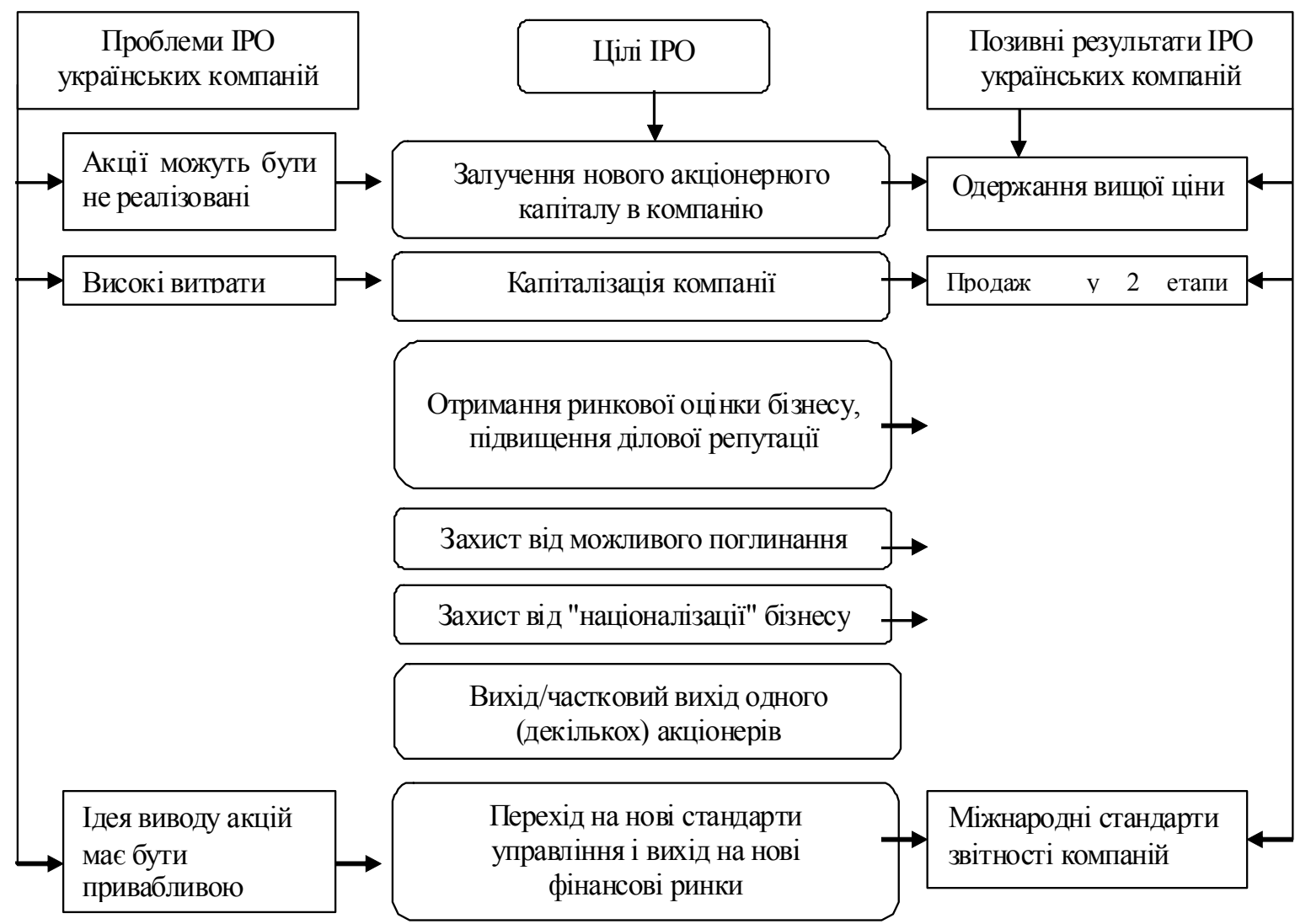

\section{Рис. 1. Цілі та напрямки здійснення IPO. Розроблено автором}

Серед основних переваг публічного статусу компанії слід назвати: можливість використання практично безмежних можливостей міжнародного фондового ринку, і відповідно, залучення значних коштів, підвищення ділової репутації і популярність на ринку, можливість залучати кредити, розміщувати облігації під нижчі відсотки. Основними недоліками IPO можна назвати: високі затрати, розтягнутість процесу у часі, втрата певного контролю над компанією, обов'язки компанії, пов'язані із публічним статусом. Серед вимог до компанії - потенційного учасника ринку
IPO можна виділити: наявність сформованої системи корпоративного управління, зрозумілої інвесторам структури активів і грошових потоків, а також прозорість для інвесторів і розкриття всіх істотних фактів своєї діяльності (зокрема, ведення бухгалтерської звітності відповідно до міжнародних стандартів). Схеми фінансування народжуються 3 переплетіння параметрів фінансування в різних площинах - форма, термін, джерело та цілі фінансування. На Рисунку 2 наведена класифікація форм фінансування. 


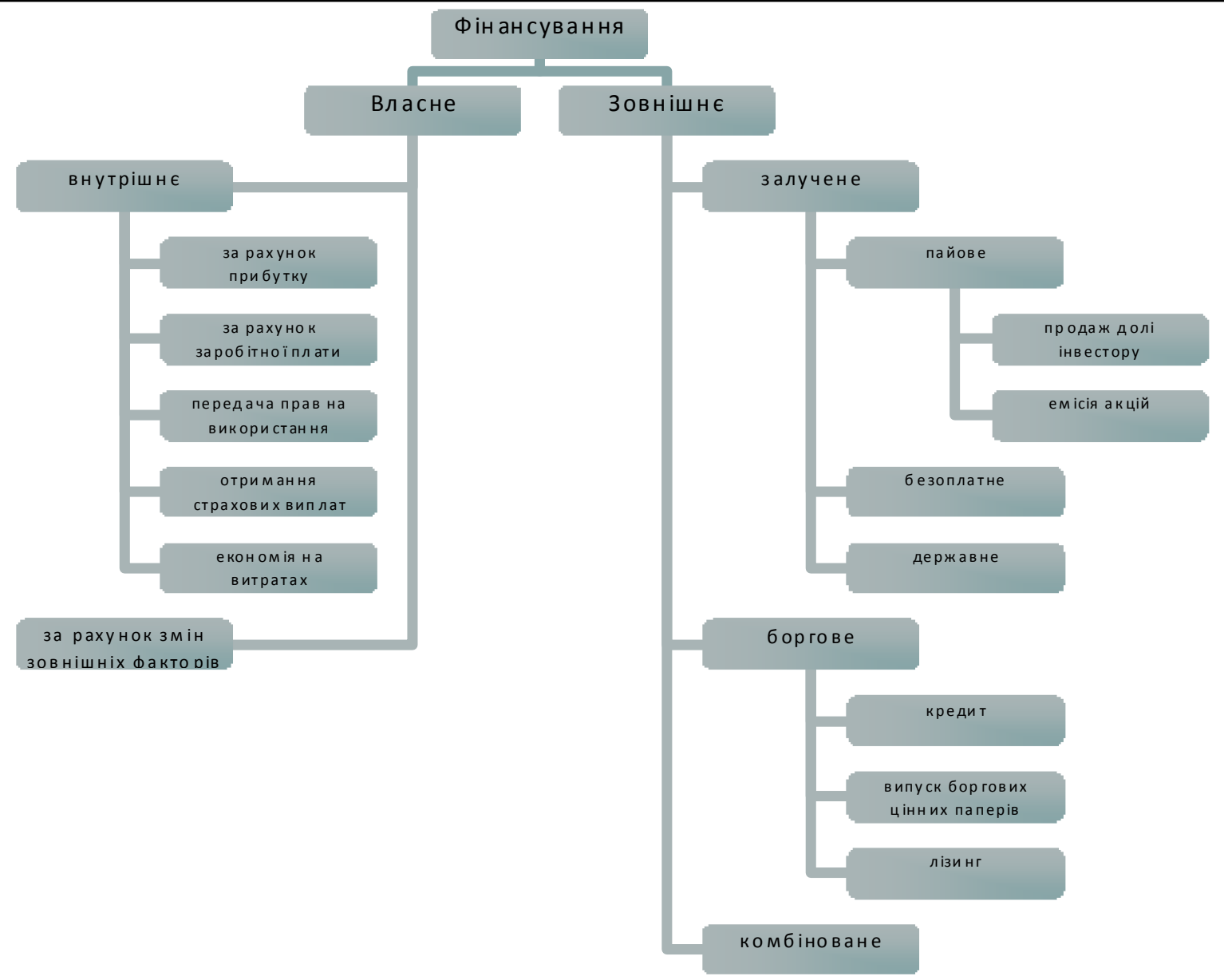

\section{Рис. 2. Класифікація форм фінансування бізнесу [3]}

Можна виділити такі основні форми фінансування підприємств:

- Власне (внутрішнє) фінансування здійснюється з власних джерел, за допомогою власного кругообігу капіталу. і такий вид фінансування підходить для більшості стійких компаній, що мають можливість самостійно поповнювати обігові кошти та створювати резерви для фінансування [ ].

- Зовнішне фінансування (залучене пайове, боргове, залучене безоплатно та комбіноване) базується на змінах діючих тенденцій в макроекономіці та на фінансових і інших ринках, на які компанії не здатна впливати, але компанія не залучає коштів ззовні. Успіху в мистецтві фінансування за рахунок змін зовнішніх факторів досягають лише ті, хто можуть відчути ці зміни та правильно спрогнозувати їх напрямок, при цьому не переоцінивши і не недооцінивши їх.

Способи зовнішнього виду фінансування пов'язані з використанням інфляції, змін ринкових цін і податків та зі зміною курсів валют. До зовнішнього фінансування відносять пайове фінансування, що характеризується участю інвестора в управлінні та фінансовому результаті компанії. Основними схемами такого фінансування є продаж долі інвестору; випуск пайових цінних паперів (емісія акцій).

Залежно від ступеня ризику в залученому фінансуванні окремо виділяють венчурне, що засноване на пайовому фінансуванні. Це передусім фінансування проектів 3 високим ступенем ризику. Порівняно 3 звичайним фінансуванням, венчурне не має забезпечення, гарантій, тому можна мінімізувати ризик лишеза рахунок фінансування проектів тих людей, котрі вже мають успішний досвід їх реалізації. Такі люди називаються венчурними підприємцями, бізнес яких полягає в тому, щоб отримати фінансування від джерел капіталізації та правильно вкласти його через прямі інвестиції в проекти на 5-7 років.

Усі схеми боргового фінансування засновані на надаванні фінансових ресурсів у тимчасове використання, частіше за все за певну плату відсоток від обсягу фінансування за певний період часу. Найпоширенішими схемами боргового фінансування $\epsilon$ кредит, випуск боргових цінних паперів, лізинг. Останнім часом набирає обертів використання таких схем, як :

- факторинг (переуступка неоплачених 
Фищук I. M.

боргових вимог або продаж дебіторської заборгованості третій особі);

- операції РЕПО ( від англ. repurchase agreement - угода про зворотній викуп: одна компанія продає іншій майно за ціною X, при цьому зобов'язується викупити майно у майбутньому, тобто компанія повертає першій за ціною Х+У у визначений термін раніше придбане майно);

- акредитив (грошове зобов'язання банку, за дорученням і за рахунок його клієнта-імпортера, здійснити оплату на користь експортера, або забезпечити платіж іншим банком, у межах певної суми та у визначений строк проти документів, що супроводжують акредитив).

Якщо порівнювати й обирати схему фінансування компанії, необхідно мати чітке уявлення про всі можливі схеми по всім можливим параметрам - змісту, ціни, доступності, надійності партнерів, впливу на фінансовий стан та ін., знання потреб у фінансуванні по всім можливим параметрам - обсягу, терміну i т. д. та відповідність схеми зі стратегією фінансування та загальною стратегією компанії.

У цьому сенсі наші компанії досить активно аналізують зарубіжний досвід, користуються моделями та розробками провідних компаній, які вже пройшли цей шлях та ми зараз можемо бути свідками зародження нових для нас, але вже не нових для світу, інструментів розвитку бізнесу. Все більше українських компаній вбачають переваги та можливості публічного ринку. Даний інструмент все ще знаходиться на стадії становлення, але його активне використання вже розпочалось.

Вихід підприємства на міжнародний ринок призводить до цілого ряду позитивних моментів як для самого підприємства, так і для економіки країни в цілому. По-перше, зовнішньоекономічна діяльність $є$ істотним чинником додаткового стимулювання стабілізації національної економіки. Одним із напрямів становлення ринкових відносин $\epsilon$ використання зовнішньоекономічних зв'язків, механізм здійснення яких в Україні в даний час докорінно реформується. По-друге, підприємства можуть гнучко й оперативно реагувати на зміни зовнішньоекономічних чинників, оптимально мобілізувати визначені виробничі ресурси 3 метою раціонального використання переваг світогосподарських зв'язків. По-третє, існує і зворотний зв'язок: партнери з різних країн у рамках господарського співробітництва 3 Україною істотно впливають на розвиток підприємництва, підвищення його технічного і технологічного рівня, що в остаточному підсумку веде до економічного росту. I, нарешті, по-четверте, підприємництво, замкнуте лише на національний господарський комплекс, позбавлене здорової конкуренції із зовні, розвивається не настільки ефективно.

Український початок використання IPО поклав 2005 рік, коли чотири підприємства вишли на альтернативний майданчик Лондонської фондової біржі (AIM LSE). Показано українські компанії, які здійснили IPO на міжнародних фондових ринках. Можна зазначити, що найбільш успішною $\epsilon$ компанія Ferrexpo, що здійснила IPO в 2007 році 3 капіталізацією у 419 млрд. доларів. Протягом 2010 року операції 3 IPO були призупинені українськими компаніями, переважно це надзвичайно затратний та тривалий процес, але компанія "Авангард" все ж таки здійснила розміщення своїх акцій на Лондонському майданчику в травні цього року і отримала 187 млн. доларів. Історя українських компаній показана в таблиці 1.

Серед основних засобів здійснення IPО можна виділити метод фіксованої ціни (відкрита пропозиція), метод аукціону та метод формування книги заявок. Для українських компаній є найбільш ефективний метод фіксованої ціни, переважно за відкритої пропозиції здійснюється вихід на міжнародний фондовий ринок.

Одним з важливих моментів на початку 2006 p. була перереєстрація прав власності на офшорну компанію. Пояснювалася ця процедура деякими особливостями українського законодавства, адже здійснення IPO на західних ринках прямо не дозволялось. Тому вітчизняні емітенти створювали холдинг, так звана SPV-компанія (special purpose vehicle - спеціально створена компанія), в офшорній юрисдикції і перереєстровували на новостворене підприємство право власності на всі українські активи. Наприклад, "Укрпродукт" створював таку компанію у Джерсі, "XXI століття" - на Кіпрі. Далі SPV-компанія здійснювала додаткову емісію, продавала іï через механізм IPO на біржі, а виручені гроші переказувала в Україну. Та 3 набранням чинності 3У "Про цінні папери i фондовий ринок" вітчизняні компанії отримали можливість домінувати свої цінні папери у валюті. Але для отримання дозволу на розміщення акцій на одній із західних бірж емітент повинен попередньо вивести свої цінні папери на українську фондову біржу.

Після IPO акції можуть дешевшати і 3 об'єктивних причин. Одна 3 них - переоціненість. Зазвичай будь-яка публічна компанія стає заручницею надто оптимістичних прогнозів аналітиків, опублікованих незадовго до розміщення. Відповідно до дослідження американських економістів, оцінки вартості акцій завищуються у середньому на 65\%. Причому до завищених оцінок схильні як незалежні аналітики, так і фахівці інвестбанків, які безпосередньо 
Розвиток IPО українських компаній

\begin{tabular}{|c|c|c|c|c|c|}
\hline Компанія & Дата & Пакет & Залучено & $\begin{array}{c}\text { Ринкова } \\
\text { капіталізація }\end{array}$ & Галузь \\
\hline $\begin{array}{l}\text { Ukrproduct } \\
\text { (AIM) }\end{array}$ & $\begin{array}{l}\text { Лютий } \\
2005\end{array}$ & $27,2 \%$ & $\begin{array}{l}6 \text { млн. } \\
\text { англійських } \\
\text { фунтів }\end{array}$ & $\begin{array}{l}16,9 \text { млн. } \\
\text { англійських } \\
\text { фунтів }\end{array}$ & Молочна промисловість. \\
\hline $\begin{array}{l}\text { Cardinal } \\
\text { Resources } \\
\text { (AIM) }\end{array}$ & $\begin{array}{l}\text { Квітень } \\
2005\end{array}$ & nla & $\begin{array}{l}\text { 10,6 млн. } \\
\text { англійських } \\
\text { фунтів }\end{array}$ & $\begin{array}{l}\text { 15,75 млн. } \\
\text { англійських } \\
\text { фунтів }\end{array}$ & Видобуток нафтти і газу. \\
\hline $\begin{array}{l}\text { XXI Century } \\
\text { Investments }\end{array}$ & $\begin{array}{l}\text { Грудень } \\
2005\end{array}$ & $35,7 \%$ & $\begin{array}{l}\text { 138,7 млн. } \\
\text { англійських } \\
\text { фунтів }\end{array}$ & $\begin{array}{l}209,15 \text { млн. } \\
\text { англійських } \\
\text { фунтів }\end{array}$ & Девелоперська компанія. \\
\hline $\begin{array}{l}\text { Astarta } \\
\text { Holding (WSE) }\end{array}$ & $\begin{array}{l}\text { Серпень } \\
2006\end{array}$ & $20 \%$ & $\begin{array}{l}\text { 31, } 5 \text { млн. } \\
\text { дол. США. }\end{array}$ & $\begin{array}{l}156 \text { млн дол. } \\
\text { США. }\end{array}$ & Виробництво цукру. \\
\hline MHP (AIM) & $\begin{array}{l}\text { II квартал } \\
2007\end{array}$ & $20 \%$ & $\begin{array}{l}371 \text { млн.дол. } \\
\text { США }\end{array}$ & $\begin{array}{l}1.7 \text { млрд. дол.. } \\
\text { США }\end{array}$ & $\begin{array}{l}\text { Збільшення потужності } \\
\text { виробничих підприємств, } \\
\text { будівництво елеваторів, } \\
\text { збільшення обсягів зернових } \\
\text { культур. }\end{array}$ \\
\hline Ferrexpo (AIM) & $\begin{array}{l}\text { Червень } \\
2007\end{array}$ & $25 \%$ & $\begin{array}{l}419 \text { млн. } \\
\text { дол. США }\end{array}$ & $\begin{array}{l}1,671 \\
\text { млрд.дол. } \\
\text { США }\end{array}$ & $\begin{array}{l}\text { Оптимізація видобування } \\
\text { залізної руди та максимальне } \\
\text { збільшення виробництва, } \\
\text { також погашення боргу та } \\
\text { виявлення можливостей } \\
\text { придбання активів. }\end{array}$ \\
\hline $\begin{array}{l}\text { Dragon- } \\
\text { Ukrainian } \\
\text { Properties and } \\
\text { Development } \\
\text { PLC (AIM) }\end{array}$ & $\begin{array}{l}\text { Червень } \\
2007\end{array}$ & $100 \%$ & $\begin{array}{l}208 \text { млн. } \\
\text { дол. США }\end{array}$ & nla & $\begin{array}{l}\text { Розвиток нових проектів, } \\
\text { реалізація проектів у секторі } \\
\text { готелебудування, покупка } \\
\text { земельних ділянок }\end{array}$ \\
\hline Авангард & $\begin{array}{l}\text { Травень } \\
2010\end{array}$ & $22,3 \%$ & $\begin{array}{l}187 \text { млн. } \\
\text { дол. США }\end{array}$ & $\begin{array}{l}938 \text { млн. дол. } \\
\text { США }\end{array}$ & $\begin{array}{l}\text { Будівництво нових яйце } \\
\text { фабрик. Розвиток нового } \\
\text { бізнесу - біогазові заводи. }\end{array}$ \\
\hline
\end{tabular}

Розроблено автором.

займаються організацією IPO компанії. Проблема, на думку американських дослідників, полягає не лише в зацікавленості інвестбанків у позитивних відгуках про компанію (що дорожче буде продано бізнес, то більше комісійних отримає інвестбанк-організатор за оборудку), а й у небажанні аналітиків публікувати негативні звіти у принципі. Будь-яка компанія в перспективі може стати клієнтом їхнього інвестиційного дому. Тому поступове сповзання паперів після IPO протягом наступних 2-3 років у більшості випадків неминуче.

Висновки. У наш час, світова економіка виходить на новий рівень свого розвитку, вимагаючи від учасників підвищення якості управління, розробок нових стратегій розвитку підприємств, пошук нових шляхів інтеграції та кооперації між провідними компаніями світу. Формування корпоративного права, швидкі темпи розвитку галузей виробництва та торгівлі, загострення конкурентної боротьби, приток іноземного капіталу вимагають від українських компаній пошуку нових джерел залучення фінансових ресурсів для розвитку свого бізнесу. Фінансування може здійснюватися з внутрішніх та зовнішніх джерел, за допомогою асигнувань 3 бюджету, кредитних джерел, закордонної допомоги, вкладів акціонерів та інших осіб.

Основним при прийнятті рішення про вихід на публічний ринок $є$ розгляд компанією альтернатив публічного розміщення акцій, оскільки дієвість проведення IPO обумовлена неефективністю чи відсутністю можливості залучення коштів іншим шляхом. Аналіз альтернативних джерел залучення капіталу буде сприяти успішному та економічно ефективному використанню IPO. Конкуренція на світових ринках настільки велика, що лише використання всього спектра фінансових ресурсів дає можливість на рівних конкурувати зі світовими гравцями. 
Фищук I. M.

\section{Список літератури: "Академія", 2000. - 864 с.}

1.Сорока М. В. IPO як механізм залучення інвестицій / .5. Никонова И.А. Ценные бумаги для бизнеса : Как повысить стоимость компании с помощью IPO, / Національний університет "Львівська політехніка" $-2007 .-350$ c.

2.Еременко А. Отпускной режим // БИЗНЕС - 2007. №3-4 (730-731) - 42-45 c.

.Гулькин П.Г. Практическое пособие по первоначальному публичному предложению акций (IPO). - СПб.: Аналитический центр "Альпари СПб", 2004. - $238 \mathrm{c}$.

3 .Лукашов А., Могин А. IPO от I до О: Пособие для финансовых директоров и инвестиционных аналитиков- М.: Альпина Бизнес Букс, 2007. - с. 257.

4 .Економічна енциклопедія у 3-х томах./ Редкол.: Мочерний(відп ред.) та ін. - Київ: Видавничий центр облигационных займов и инвестиционных операций. - Москва: Альпина Бизнес Букс, 2006. - 350 с.

.6. Кукса В. Це солодке слово IPO. Українські підприємства відкривають для себе прогресивний спосіб інтеграції у світову економіку // Дзеркало тижня. - 2007. - № 35 (664). - Доступний 3: <http:// www.dt.ua/2000/2020/60513>

7. Давиденко Б. Історії українських акцій на західних біржах. - Київ, 2010. - Доступний 3: <http:// $\mathrm{u}$ k r r u d p r o m . c o m / d i g e s t / Istorii_ukrainskih_aktsiy_na_zapadnih_birgah.html $>$.

8. Прудковских В. Рынок крупных сделок// Комп\&ньоН - 2007. №4. - 54-57 c.

\section{Аннотация}

И. Фищук

\section{УКРАИНСКАЯ КОМПАНИЯ НА МЕЖДУНАРОДНОМ ФОНДОВОМ РЫНКЕ}

Рассмотрено особенности первичного размещения акций (IPO) украинских компаний в период глобализачии фондового рынка. Установлено, что публичное предложение инвесторам является одним из наиболее привлекательных способов привлечения средств, так как имеет существенные преимущества в сравнении с кредитованием и выпуском облигачий.

Ключевые слова: Ценные бумаги, акции, инвестиции, фондовый рынок.

\section{Summary}

I. Fyshchuk

\section{UKRAINIAN COMPANIES IN INTERNATIONAL STOCK MARKETS}

In this article the features of Initial Public Offerings (IPO) of the Ukrainian companies are considered in conditions of globalization of the stock market. The public offering to the investors is one of the most attractive methods of bringing in of money, as has a row of advantages by comparison to crediting and bonding.

Key words: Securities, shares, investments, stock market. 
УДК 339.9.012.23

\author{
(C) Фреяк А.В., 2011 \\ Інститут міжнародних відносин \\ Киӥвського національного університету ім. Тараса Шевченка, м.Київ
}

\title{
РОЛЬ ТРАНСКОРДОННОГО СПІВРОБІТНИЦТВА У РЕГІОНАЛЬНОМУ РОЗВИТКУ ТА ІНТЕГРАЦЙНИХ ПРОЦЕСАХ
}

\begin{abstract}
Проаналізовано та узагальнено кониептуально-теоретичні та правові засади транскордонного співробітництвва України, розглянуто процес розвитку транскордонного співробітниитва в Украйні з сусідніми державами СС $і$ СНД та визначено участь в ньому прикордонних західних областей.

Ключові слова: транскордонне співробітництво, транскордонний регіон, євроінтеграція,
\end{abstract} єврорегіон, зовнішньоторговельний оборот.

Актуальність теми дослідження. У сучасних умовах розвитку світової економіки міжнародні інтеграційні процеси стають визначальними і значною мірою набувають регіонального відтінку. Все більша роль у міждержавних відносинах надається регіонам. У зв'язку з цим, зростає значення транскордонного співробітництва. Такий вид співробітництва, починаючи з середини минулого століття, отримав особливе поширення у країнах Західної Свропи, де вже накопичено багаторічний досвід здійснення транскордонної співпраці, спрямованої на посилення та поглиблення добросусідських взаємовідносин між територіальними общинами або органами влади. Для України, яка обрала курс зовнішньоекономічної політики в напрямку інтеграції до Європейського Союзу, транскордонне співробітництво відіграє важливу роль, так як, за умови ефективного здійснення, $\epsilon$ рушієм економічного розвитку регіонів та спонукає до прискорення процесів конвергенції та інтеграції.

Ступінь наукової розробки. 3 кінця минулого століття проявилася значна зацікавленість науковців до проблематики регіонального розвитку і транскордонного співробітництва. Велику увагу цим питанням приділили зарубіжні вчені - З.Горжеляк, П.Еберхардт, Т.Коморніцкі, Т.Лієвські, З.Макєла, М.Ростішевскі, Р. Ратті та українські - П.Бєлєнький, З.Бройде, В.Будкін, Є.Кіш, М.Долішній, Н. Мікула, Н.Луцишин, I.Студенніков та інші. Ними обгрунтовано категоріальний апарат транскордонного співробітництва, узагальнено досвід діяльності транскордонних об'єднань країн Західної Свропи, вивчено вітчизняну практику участі прикордонних регіонів у транскордонному співробітництві. Проте, незважаючи на велику кількість наукових праць, 3 аналізу проблем євроінтергації та транскордонного співробітництва, залишається ще низка питань, що досліджена недостатньо. Існує необхідність подальших наукових

досліджень, пов'язаних з уточненням теоретичних термінів, 3 оцінкою стану транскордонної економічної та єврорегіональної співпраці.

Метою статті $\epsilon$ поглиблення науковотеоретичних основ розвитку транскордонного співробітництва, як інструменту прискорення євроінтеграційних процесів та чинника регіонального розвитку в Україні.

Виклад основної частини. Однією 3 характерних рис інтеграційних та субінтеграційних процесів в Європі на межі XX - XXI століття став розвиток транскордонного співробітництва. Його активізація зумовлена, передусім, реалізацією мети загальноєвропейського значення "розмивання" кордонів між країнами членами Євросоюзу. Транскордонне співробітництво спрямоване на подолання негативних аспектів існування кордонів та наслідків, які виникли на прикордонних територіях через їх розташування на національних окраїнах держав і має на меті покращення умов життя населення. Серед головних цілей такої співпраці $є$ : подолання існуючих стереотипів та упереджень по обидві сторони кордону; усунення політичних та адміністративних бар'єрів між сусідніми народами; створення господарської, соціальної та культурної інфраструктури, за умови формування спільних органів, господарюючих суб'єктів, осередків тощо [7,c.12-13].

На початковому етапі свого розвитку транскордонне співробітництво зводилось до проведення культурних фестивалів, проте на сьогоднішній день - це серйозне співробітництво за багатьма напрямками, що включає економічне співробітництво, кооперацію у сфері туризму, захист навколишнього середовища, соціальну і культурну співпрацю.

Уперше термін "транскордонне співробітництво" був введений у Європейській рамковій конвенції про транскордонне співробітництво між територіальними общинами 
Фреяк А. В.

або властями і означає "... будь-які спільні дії, спрямовані на посилення та поглиблення добросусідських відносин між територіальними общинами або властями, які знаходяться під юрисдикцією двох або декількох Договірних сторін, та на укладення 3 цією метою будь-яких необхідних угод або досягнення домовленостей" [3]. Це визначення, що міститься у базовому європейському документі Ради Європи 3 транскордонного співробітництва, який підписаний країнами-членами Ради Свропи в м. Мадрид 21 травня 1980 року, - є загальноприйнятим у Свропі [2]. Відповідно до вищезазначеного документа, транскордонне співробітництво сфокусовано на співпрацю суміжних регіонів, територій сусідніх країн, які мають спільний кордон. Наявність спільного кордону є принципово важливою умовою для розвитку транскордонного співробітництва сусідніх територій [2].

Для всіх держав Європи, які ратифікували Європейську Рамкову Конвенцію про транскордонне співробітництво між територіальними общинами або властями, основні положення і принципи вищезазначеної так званої Мадридської Конвенції 3 міжнародно-правової точки зору є загальноприйнятими. Внаслідок ратифікації Мадридської Конвенції Верховною Радою України у 1993 році, положення Конвенції (міжнародно-правові норми стосовно транскордонного співробітництва, закріплені у Конвенціï) стали частиною національного законодавства України і мають пріоритет над внутрішнім правом згідно зі статтею 27 Віденської Конвенції про право міжнародних договорів 1969 року [2].

Концептуальні засади транскордонного співробітництва України формуються виключно на принципах і правових механізмах нормативноправових актів Європи та України 3 питань транскордонного співробітництва. До законодавчої бази України, що регламентують транскордонні відносини, відносяться як національні нормативноправові акти, так і низка двосторонніх угод, що регулюють співробітництво між Україною та державами в питаннях режиму кордону, пересування людей, транспортних засобів і товарів через кордони. До регламентації транскордонного співробітництва мають пряме відношення також документи, що визначають стратегічні напрями євроінтеграційного курсу України.

24 червня 2004 р. був прийнятий Закон України "Про транскордонне співробітництво", який серед іншого визначає мету та принципи державної політики у сфері транскордонного співробітництва, повноваження суб'єктів транскордонного співробітництва України, принципи та форми державної підтримки транскордонного співробітництва та його фінансове забезпечення [4]. Згідно 3 вищезазначеним законодавчим документом транскордонне співробітництво розглядається як спільні дії, спрямовані на встановлення і поглиблення економічних, соціальних, науково-технічних, екологічних, культурних та інших відносин між територіальними громадами, їх представницькими органами, місцевими органами виконавчої влади України та територіальними громадами, відповідними органами влади інших держав у межах компетенції, визначеної їх національним законодавством. Проте, на думку автора, це визначення має певні розбіжності із визначенням в Конвенції, оскільки в законі не йдеться про обов'язковість сусідства держав-учасниць співробітництва. Отже, таке визначення має відношення як до співпраці сусідніх так і не сусідніх держав. А це не відповідає загальноприйнятим уявленням про транскордонне співробітництво, оскільки транскордонне співробітництво є співпрацею сусідніх держав [3].

Відповідно до нормативних документів із зазначеного напрямку можна виділити такі основні пріоритети транскордонного співробітництва України: зміцнення конкурентоспроможності регіонів країни; спрощення процесу перетину кордону та створення відповідної інфраструктури; укладання нових транскордонних угод; розвиток мережі консалтингових центрів і центрів підтримки малого та середнього підприємництва в прикордонних регіонах; координація соціальноекономічного та екологічного розвитку прикордонних регіонів; гармонізація законодавства України у відзначених сферах 3 європейським законодавством [10].

У науковій літературі терміном "транскордонне співробітництво" характеризують території інтенсивного прикордонного співробітництва у всіх сферах життя. Такими є сукупні прикордонні території двох або більше сусідніх держав 3 високим наявним або потенційним рівнем прикордонного співробітництва. Транскордонне співробітництво сприяє пожвавленню регіонального розвитку, активному включенню країн у сучасний інтегрований світ. Воно належить до економічних процесів, що набули інтенсивного розвитку під впливом міжнародної економічної інтеграції. 3 розширенням і поглибленням економічного співробітництва європейських країн прикордонні регіони все більш стають зонами контакту національних господарств. У системі транскордонного співробітництва підтримуються і розвиваються різноманітні зв'язки: торговельні, господарські, культурні, наукові, туристичні тощо.

Транскордонне співробітництво здійснюється в форматі транскордонних регіонів. Зміст поняття 


\section{РОЛЬ ТРАНСКОРДОННОГО СПВРОБІТНИЦТВА У РЕГІОНАЛЬНОМУ РОЗВИТКУ ТА}

ІНТЕГРАЦЙНИЇХПРОЦЕСАХ

"транскордонний регіон" став об'єктом дискусії як серед зарубіжних вчених, так і привернув увагу українських дослідників [11]. Так, Н. Луцишин вважає, що "транскордонний регіон - це наявність щонайменше двох територій різних країн, що мають спільний державний кордон, між якими встановились тісні виробничі і соціальноекономічні зв'язки. Про об'єктивний процес формування транскордонного регіону свідчить рівень розвитку різного роду зв'язків (виробничих, соціально-економічних тощо), які здійснюються між двома територіями різних країн, що мають спільний кордон. Без наявності таких зв'язків не може формуватись транскордонний регіон" [6].

I. Студенников також запропонував своє визначення цього поняття: "Під транскордонним регіоном слід розуміти певну територію, яка характеризується наявністю схожих природногеографічних умов і охоплює прикордонні території двох або кількох держав, що мають спільний кордон" [10]. Проте, зазначимо, що, окрім подібних природно-географічних і геополітичних умов транскордонного регіону, важливими характеристиками $€$ наявність міцних етнокультурних зв'язків, домінування певних мовних і релігійних орієнтацій громадян і спільне історичне минуле народів, що проживають на його території. Сукупність усіх факторів сприяє поглибленню співробітництва в різних галузях в рамках транскордонного регіону.

На відміну від поняття "прикордонний регіон", яке визначається як територія, що охоплює одну або декілька адміністративно-територіальних одиниць однієї держави та прилягає до державного кордону, транскордонний регіон характеризується приналежністю декільком державам, які мають спільний кордон і $\epsilon$ територією, що охоплює прикордонні адміністративно-територіальні одиниці сусідніх держав [4]. Транскордонний регіон може охоплювати суміжні території декількох країн, як наприклад, Волинська область України, Брестська область Білорусіі, Люблінське воєводство Польщі чи Закарпатська область України, область Саболч-Сатмар-Берег Угорщини та край Кошіце Словаччини.

Виходячи 3 вищенаведених визначень транскордонного співробітництва та транскордонного регіону, автор пропонує розглядати транскордонне співробітництво як сукупність спільних дій в економічній, соціальній, культурній, гуманітарній, науково-технічній та інших сферах, що виникають між територіальними громадами або властями сусідніх держав в межах транскордонного регіону і спрямовані на вирішення завдань просторового розвитку, розв'язання спільних проблемних питань та поглиблення добросусідських відносин на його території.

Транскордонне співробітництво проявляється різними формами. Як виділяє Н. Мікула, найпростішою формою транскордонного співробітництва $є$ прямі контакти між територіальними громадами - містами, селищами, які, здебільшого, носять неформальний характер та спрямовані на спільні дії у випадку виникнення надзвичайних ситуацій [7, с.13-14]. Співпраця на неформальній основі можлива завдяки відсутності взаємних фінансових зобов'язань. Співпраця формується на договірній основі, якщо з'являються довгострокові відносини між територіальними громадами або органами влади та у випадку виникнення взаємних зобов'язань в наданні послуг, продукції, інформації, а також 3 появою фінансових зобов'язань. У цьому випадку можна виділити дві форми співпраці: безпосередньо за укладеними транскордонними угодами або шляхом формування органу транскордонного співробітництва. Співпраця безпосередньо за укладеними угодами передбачає періодичні зустрічі сторін, формування спільних комітетів та робочих груп 3 метою координації та об'єднання зусиль для вирішення спільних проблем. Фінансування діяльності учасників спільних комітетів та робочих груп можуть здійснюватися кожною стороною окремо, або шляхом об'єднання коштів на окремому спільному рахунку. Угода про транскордонне співробітництво може передбачати створення органу транскордонного співробітництва (наприклад, єврорегіону, структурного підрозділу органів влади тощо). Орган транскордонного співробітництва виконує завдання, покладені на нього територіальними громадами або органами влади, у відповідності до цілей його діяльності та у спосіб, передбачений національним законодавством.

Як форма транскордонного співробітництва, широкого розвитку набула співпраця в рамках єврорегіонів або єврорегіональне співробітництво.

Сврорегіони - це вища організаційна форма транскордонної співпраці адміністративнотериторіальних одиниць сусідніх країн. Співробітництво в рамках єврорегіонів надає додаткові інструменти для впровадження інфраструктурних проектів на державному кордоні, у сфері транспорту, туризму й охорони довкілля, сприяє запровадженню інноваційної моделі розвитку регіонів, посиленню економічних зв'язків та бізнес-активності, наукового, освітнього, культурного обміну та міжлюдських контактів, а також виконання економічних і соціальних проектів.

Протягом останнього десятиріччя українськими дослідниками зроблено чимало 
Фреяк А. В.

спроб визначити поняття єврорегіону. Проте універсальної та загальноприйнятої дефініції так і не існує. Серед усіх запропонованих вітчизняними науковцями визначень, найширше, на думку автора, розкриває сутність даного поняття визначення I. Студенникова: єврорегіон - це форма транскордонного співробітництва між територіальними громадами або місцевими органами влади прикордонних регіонів двох або більше держав, що мають спільний кордон, яке спрямоване на координацію взаємних зусиль i здійснення ними узгоджених заходів в різних сферах життєдіяльності у відповідності до національних законодавств і норм міжнародного права для вирішення спільних проблем і в інтересах людей, що населяють його територію по різні сторони державного кордону [11].

Єврорегіони, як форма транскордонного співробітництва, сприяють не тільки посиленню та поглибленню добросусідських відносин між державами, а й є своєрідним інструментом для інтеграції тієї або іншої країни до європейських структур. Це особливо важливо для України, яка обрала курс зовнішньоекономічної політики в напрямку інтеграції до Свропейського Союзу.

Україна має значний потенціал для розвитку транскордонного співробітництва, як одного 3 напрямків реалізації євроінтеграційних прагнень, що пояснюється унікальним геополітичним положенням країни, оскільки 19 з 25 регіонів держави прикордонні, а зовнішній кордон найдовший серед європейських країн. Наша держава межує 34 країнами СС: Польщею - 542,3 км, Словаччиною - 98,7 км, Угорщиною - 135,1 км та Румунією - 608,6 км [12]. Україна має один iз найвищих у Свразії показників центральності якщо взяти всю множину країн регіону, то тільки Росія та Китай мають більше сусідів [1]. Після розширень ЄС 2004-2007 років склалися сприятливі можливості як для поглиблення i розширення єврорегіонального співробітництва України, так і для збагачення форм транскордонної співпраці.
Транскордонне співробітництво у найпростіших його формах відбувається постійно, а значить постійно відбувається і формування інтегрованого простору у транскордонному регіоні. Можна сказати, що транскордонне співробітництво $є$ попереднім, доповнюючим елементом інтеграції країни. Початковий етап розвитку транскордонного співробітництва в Україні на західному кордоні швидкими темпами перейшов до вищої організаційної форми - єврорегіонів, де створено і діють 4 єврорегіони - проте на сході держави спочатку була створена Рада керівників прикордонних областей України, Росії та Білорусі і лише відносно недавно були створені єврорегіони "Дніпро", "Слобожанщина", "Ярославна" та "Донбас".

Розвиток транскордонного співробітництва $€$ основою розвитку співпраці не тільки у межах територіальних утворень, але і на рівні всієї національної економіки. Так, за підрахунками автора, в 2009 році в сукупному зовнішньому товарообігу товарами і послугами України торгівля 3 країнами-сусідами серед країн СНД та ЄС складає близько 33\%: у сукупному експорті нашої країни їх частка становить $32 \%$, а в сукупному імпорті - 34\% [8;13]. Причому торговельні відносини України, в основному, залежать від зв'язків з сусідніми країнами СНД: їх частка серед країн-сусідів становить близько 90\%, відповідно на країни СС припадає 10\% [8].

Показники зовнішньоекономічної діяльності свідчать про позитивні тенденціi розвитку транскордонного співробітництва на заході України. Динаміка зовнішньоторговельного обороту західних прикордонних регіонів України з європейськими державами протягом останнього десятиліття характеризувалася тенденцією до зростання, за винятком 2009 р., коли рестрикційний вплив здійснила світова фінансова криза (Таб.1). Щорічне зростання зовнішньоторговельного обороту 3 країнами Свропи пов'язано з більш активним включенням країни у глобалізаційні процеси та активним залученням саме прикордонних регіонів у зовнішньоекономічну діяльність.

Табличя 1

Динаміка зовнішньоторговельного обороту України з країнами Свропи, \%*

\begin{tabular}{|c|c|c|c|c|c|c|c|c|c|}
\hline & 2001 & 2002 & 2003 & 2004 & 2005 & 2006 & 2007 & 2008 & 2009 \\
\hline $\begin{array}{l}\text { Західні } \\
\text { області }\end{array}$ & 120,6 & 109,4 & 153,4 & 126,5 & 104,1 & 125,6 & 140,1 & 122,3 & 59,1 \\
\hline Україна & 117,0 & 114,8 & 139,4 & 126,9 & 110,2 & 125,7 & 129,5 & 133,4 & 55,4 \\
\hline
\end{tabular}

*складено автором на основі статистичних даних 


\section{РОЛЬ ТРАНСКОРДОННОГО СПВРОБІТНИЦТВА У РЕГІОНАЛЬНОМУ РОЗВИТКУ ТА ШНТЕГРАШЙНӤ̈ХПРОШЕСАХ}

Для західних областей показники зовнішньої торгівлі товарами і послугами із сусідніми країнами займають значну частку у їx загальнообласних показниках. Так, за результатами 2009 року, для Львівської області питома вага зовнішньоторговельного обороту 3 сусідніми країнами-членами СС у загальному показникові зовнішньоторговельного обороту по області складає 31\% (основним партнером є Польща - майже 26\%), для Закарпатської області цей показник становить -37,3\% (на Угорщину припадає близько 27\%) [8]. Чернівецька область активно розвиває зовнішньоторговельну діяльність із країнами-сусідами із ЄC та Молдовою. На ці країни припадає 25\% зовнішньоторговельного обороту товарами i послугами області. Показники зовнішньої торгівлі товарами і послугами західних областей України iз сусідніми країнами СС наочно відображено в діаграмі (Рис.1).

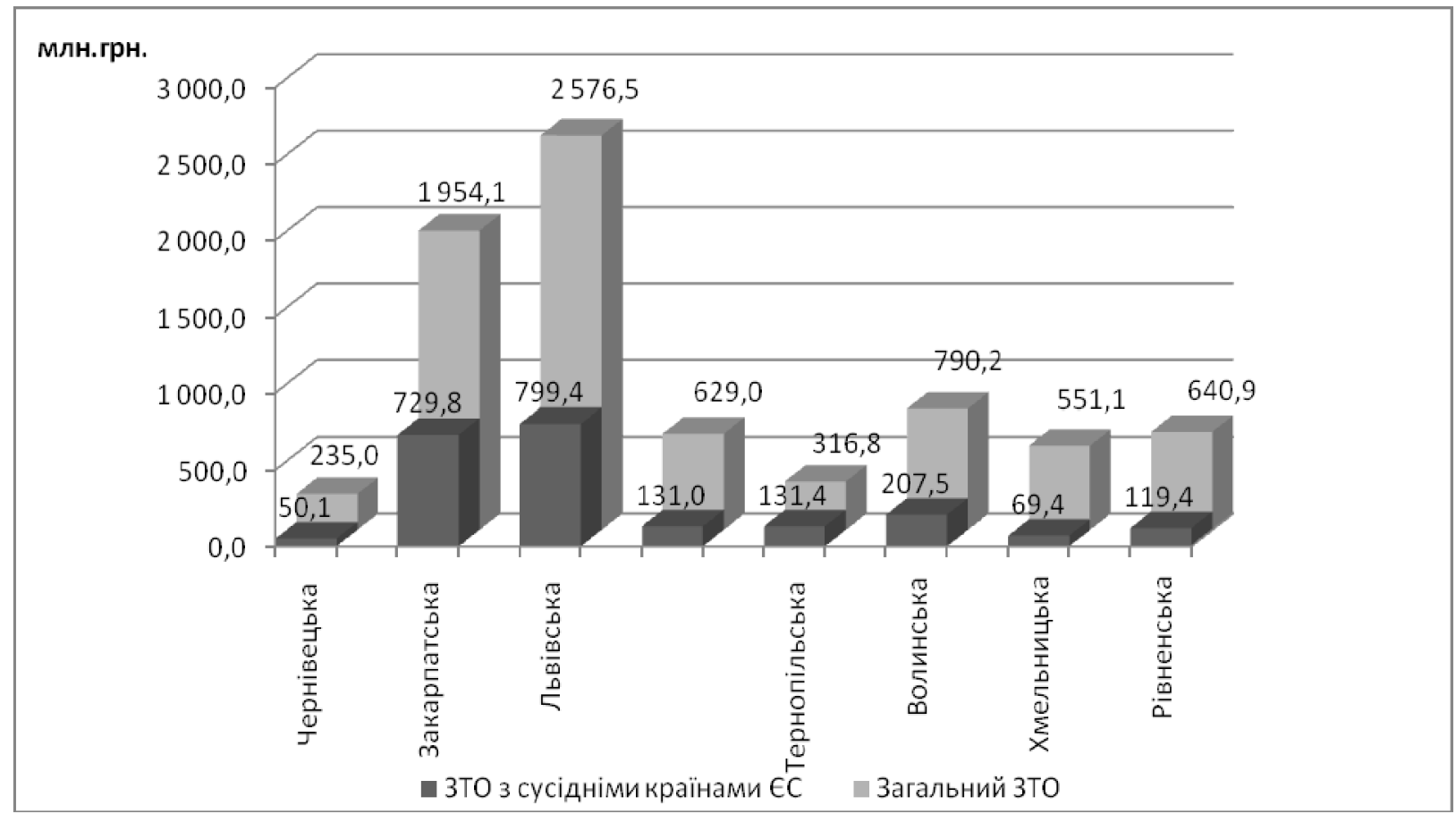

Рис. 1. Зовнішньоторговельний оборот товарами і послугами західних областей України із сусідніми країнами СС у 2009 році

Важливе значення у взаєминах між країнами відіграє рух не тільки товарів і послуг, але і капіталу, особливо у вигляді інвестицій. У Україні, станом на 01.01.2010 найбільше прямих іноземних інвестицій надійшло з Кіпру та Німеччини ( питома вага в загальному обсязі - 22,5\% та $16,5 \%$ відповідно) [8]. У взаєминах в рамках транскордонного співробітництва в Україну найбільша частка інвестицій надійшла з Росії, що в сукупному обсязі становить 7\%, з Польщі - 2,2 $\%$. Значну частку прямих інвестицій з сусідніх країн вкладено у західні області. Станом на 01.01.2010p. у Волинській області питома вага прямих іноземних інвестицій із сусідніх європейських країн в загальнообласному показникові становить понад 50\% (48,9\% інвестиції з Польщі). У Львівській області цей показник складає 29\% (26,5\% - польські інвестиційні надходження). У Закарпатській області частка прямих інвестицій з сусідніх країн
ЄС становить понад 21\%, по 9,3\% припадає на Польщу та Угорщину.

На жаль, за умов відсутності транскордонної статистики в Україні складно виділити аналогічні показники в рамках співпраці між прикордонними регіонами України та партнерськими регіонами сусідніх країн. Проте, можна констатувати, що вищенаведені показники свідчать про зацікавленість з боку іноземних інвесторів і торговельних партнерів із сусідніх країн до участі у співробітництві в рамках транскордонного регіону.

Висновки. Транскордонне співробітництво в Україні стає одним 3 важливих напрямів європейської інтеграції, що здійснюється на регіональному рівні, і починає посідати провідне місце у процесі формування ii регіональної політики. Поглиблення транскордонного співробітництва відкриває нові можливості для активізації господарської діяльності на 
Фреяк А. В.

периферійних територіях і підвищення їх конкурентоспроможності шляхом мобілізації природно-ресурсного потенціалу сусідніх територій.

Роль транскордонного співробітництва є багатогранною. По-перше, транскордонне співробітництво є чинником інтеграційного процесу, що сприяє досягненню вільного переміщення товарів, людей та капіталів через кордон. По-друге, транскордонне співробітництво сприяє мобілізації місцевих ресурсів та їх ефективному використанню з метою підвищення життєвого рівня населення прикордонних територій. По-третє, транскордонне співробітництво робить можливим об'єднання зусиль для вирішення спільних проблем у транскордонному регіоні.

\section{Список літератури}

1. Артьомов I. Актуальні аспекти вибору напряму єврорегіонального співробітництва в контексті досвіду Вишеградської четвірки: Україна між ЄС та Росією.- Режим доступу: http://www.9world.com.ua/ $\mathrm{ru} /$ proekty/ukraina-i-rossija/993-ukraina-mizh-yes-tarosiyeju.html

2. Гарагонич В.В. Концептуальні засади транскордонного співробітництва України // Наукові праці: Науково-методичний журнал. - Т. 115. Вип. 102. Історичні науки. - Миколаїв, 2009. - С. 69-73.

3. Європейська Рамкова Конвенція про транскордонне співробітництво між територіальними общинами або властями (ETS No106) - Мадрид, 21 травня 1980 р. - Режим доступу: http://zakon.rada.gov.ua/cgi-bin/laws/main.cgi.
4. Закон України "Про транскордонне співробітництво", прийнятий Постановою ВРУ від 24 червня 2004 p. №1861-IV.- [Електронний ресурс]. Режим доступу: http://zakon.rada.gov.ua

5. Кулєшова Г. Прикордонний регіон як об'єкт суспільно-географічних досліджень.-Електронний pecypc.-Режим доступу: http://www.nbuv.gov.ua/ portal/Soc_Gum/Chseg/2008_5/Kuleshova.pdf

6. Луцишин Н. Розвиток і функціонування транскордонного об'єднання - Сврорегіону "Буг" // На шляху до Європи. Український досвід єврорегіонів / За ред. С. Максименка, І. Студеннікова. - К. 2000. - С. 77.

7. Мікула Н. Сврорегіони: досвід та перспективи. Львів: ІРД НАН України, 2003. - 222 с.

8. Статистична інформація Державного комітету статистики України.- Електронний ресурс.-Режим доступу: http://www.ukrstat.gov.ua

9. Студенніков I. Транскордонне співробітництво та його місце в регіональному розвитку. // Регіональна політика в країнах Свропи: Уроки для України / Київ. центр Ін-ту Схід-Захід; за ред. С.Максименка. - К.: Логос, 2000. - С. 138-167.

10. Студенніков І. Б. Транскордонне співробітництво як дзеркало регіональної політики в Україні [Електронний ресурс]. - Режим доступу: http:// www.niss.od.ua

11. Студенников I. Феномен єврорегіонів в контексті методології історико-регіональних досліджень // Історія України. Маловідомі імена, події, факти. - Вип. 22-23. - Київ, 2003. - С. 187-201.

12. Україна - WWW Енциклопедія Київа. Електронний ресурс. -Режим доступу:http:// webcache.googleusercontent.com/search?q=cache: e5km1yzq3uUJ: wek.kiev.ua/uk.

13. Прим. До сусідніх країн ЄС віднесено Польщу, Румунію, Словаччину та Угорщину. До сусідніх країн СНД - Білорусь, Молдову, Росію. 


\section{Аннотация}

Алена Фреяк

\section{РОЛЬ ТРАНСГРАНИЧНОГО СОТРУДНИЧЕСТВА В РЕГИНАЛЬНОМ РАЗВИТИИ И ИНТЕГРАЦИОННЫХ ПРОЦЕССАХ}

Проанализированы и обобщены конщептуально-теоретические и правовые основы трансграничного сотрудничества Украины, рассматривается прочесс развития трансграничного сотрудничества Украины с соседними странами ЕС и СНГ, выделяется участие в нем приграничных западных областей.

Ключевые слова: трансграничное сотрудничество, трансграничный регион, евроинтеграция, еврорегион, оборот внешней торговли.

\section{Summary}

Alyona Freyak

\section{ROLE OF CROSS-BORDER COOPERATION IN REGIONAL DEVELOPMENT AND INTEGRATION PROCESSES}

Conceptual, theoretical and legal principles of cross-border collaboration of Ukraine are analyzed and generalized in the article. Author investigates the process of development of cross-border cooperation in Ukraine with nearby states of EU and NIS, boundary western region participation in this process is distinguished.

Key words: cross-border cooperation, cross-border region, eurointegration, euroregion, foreign trade turnover. 
УДК 339.5.053 (477)

(C) Товарницька B.Є., 2011

Чернівецький національний університет імені Юрія Федьковича, м. Чернівці

\title{
АНАЛІЗ ПОКАЗНИКІВ ЕКСПОРТУ Й ІМПОРТУ ТОВАРІВ ЯК ФАКТОРІВ ФОРМУВАННЯ КОНКУРЕНТОСПРОМОЖНОСТІ ЕКОНОМІКИ УКРАЇНИ В УМОВАХ ГЛОБАЛІЗАЦІї
}

\begin{abstract}
Подається аналітична оцінка деяких зовнішніх факторів формування конкурентоспроможності національної економіки, а саме експорту та імпорту товарів Украӥни у регіональному розрізі за 2009-2010 роки, підтримуючи тезу про те, щзо ключовою ланкою у виріменні питання конкурентоспроможності країни є ї̈ регіони. Автор обтрунтовує ідею поділу адміністративно-територіальних одиниць на територіально-промислові райони, що сприятиме підвищенню рівня конкурентоспроможності національної економіки в иілому.

Ключові слова: конкурентоспроможність, конкурентоспроможність начіональної економіки, глобалізація, конкурентоспроможність регіону, експорт та імпорт товарів.
\end{abstract}

Постановка проблеми. Глобалізація відкриває перед людством величезні можливості для розширення масштабів обміну товарами, послугами, інформацією, технологіями і капіталом, взаємодії в гуманітарній сфері та духовного збагачення особистості. В умовах глобалізації, поглиблення міжнародного поділу праці та кооперування Україна входить до системи світового господарства як країна 3 високим рівнем відкритості економіки, що передбачає розширення взаємозв'язків з іншими країнами.

Внаслідок існування тісного зв'язку між розвитком економіки та рівнем життя у суспільстві регулювання економічного механізму має пов'язуватися з удосконаленням методів, що надають розвитку нового поштовху. А отже, створення умов підвищення конкурентоспроможності (далі - КСП) економіки $\epsilon$ одним із головних факторів забезпечення високого рівня життя нації. Водночас підвищення добробуту нації на основі високого рівня конкурентоспроможності є не тільки основною метою уряду, а й загальнонаціональним завданням, до вирішення якого мають бути залучені всі верстви українського суспільства.

Аналіз останніх досліджень і публікацій. Вивченню та аналізу цих питань присвячено значну кількість наукових досліджень у світовій економічній літературі та робіт вітчизняних авторів. Відомими західними фахівцями, центральноєвропейськими дослідниками у сфері забезпечення КСП, зокрема, зважаючи на реалії транзитивних економік, $є$ А. Аслунд, П. Брентон, Дж. Стіглиць, Я. Корнаї, Р. Лукас, П. Лукач, Д. Нордт, М. Портер, Дж. Сакс, В. Скотт, Р. Солоу, Н. Стерн, М. Тодаро.

Ці питання, а також практичні завдання підвищення КСП національної економіки України висвітлювалися у працях вітчизняних дослідників: О. Білоруса, В. Будкіна, І. Бураковського, О.
Власюка, М. Дудченка, В. Сременка, А. Кредісова, Д. Лук'яненка, В. Новицького, В. Онищенка, Є. Панченка, Т. Панфілової, Ю. Пахомова, А. Поручника, В. Рокочой, А. Румянцева, В. Сіденка, А. Філіпенка та інших.

Нерозв'язані раніше частини загальної проблеми. Водночас, хоча проведені дослідження розкривають чимало важливих теоретичних питань конкурентоспроможності в умовах сучасної глобалізації, особливостей практичних методів регулювання національних механізмів відтворення та комерційної діяльності, зокрема за умов транзитивної економіки, відчувається потреба в осмисленні ролі зовнішніх факторів забезпечення конкурентоспроможності країни в умовах глобалізації та в обгрунтуванні практичних кроків для зростання конкурентоспроможності регіонів країни та національної економіки в цілому.

Формулювання цілей статті. В умовах кризи для країн, що розвиваються, таких як Україна, важливим стає посилення конкурентної боротьби за світові фінансові ресурси. Очевидно, що країни, які зможуть запропонувати найбільш конкурентне економічне середовище для залучення міжнародного капіталу, матимуть більше можливостей вийти з кризи першими і $з$ відносно меншими втратами.

КСП національної економіки утворюється під впливом низки чинників. Створення політично стабільного суспільства та ефективно функціонуючої економіки неможливі без подолання відмінностей в рівнях розвитку різних регіонів України: західних і східних, промислових і аграрних.

КСП економіки країни є наслідком КСП їі регіонів, яку можна визначити як їхню здатність тривалий час реалізовувати власні та залучені можливості для розвитку на сучасній технологічній основі, забезпечуючи внутрішній та 
глобальний ринок товарами і послугами відповідної якості [1].

Перспективи зовнішньоекономічного розвитку розглядаються нами 3 огляду на експортний потенціал країни, який визначає іiі конкурентні переваги на світовому ринку. Експортний потенціал країни в цілому складається 3 експортних потенціалів окремих регіонів, що є активними самостійними структурними одиницями у зовнішньоекономічних відносинах. Вони визначають не лише забезпеченість національної економіки ресурсами, а й здатність системи до розвитку на базі наявних ресурсів.

Викладення основного матеріалу дослідження. Аналіз показників експорту та імпорту товарів свідчить, що Україна загалом та їі регіони зокрема з року в рік нарощують обсяги зовнішньої торгівлі. Саме експортні позиції, на нашу думку, є вагомою складовою поточного рівн конкурентоспроможності економіки України.

Слід зауважити, що всі параметри регіонів аналізувались у \% до загального підсумку по Україні, а також на душу населення, за 2009 та 2010 роки. Для додаткового аналізу даних, у рамках дослідження за конкретним фактором, можна класифікувати регіони України за групами A, B, C, D, E у спадному порядку і результати зіставити 3 аграрно-промисловою характеристикою кожного регіону. Діапазони показників у \% до загальних підсумків по Україні для визначення груп, до яких належать різні регіони України, наступні: група А - понад 9\%, група В 4-9\%, група С - 2-4\%, група D - 1-2\%, група Е - 0$1 \%$.
За питомою вагою (далі - ПВ) у загальному обсязі експорту товарів у 2009-2010 рр. найкращі показники належать промисловим регіонам України, а саме: Донецькій обл. - 25,5\% у 2010 р. i 23,5\% у 2009 р., Дніпропетровській - 15,6\% у 2010 p. і 17,2\% у 2009 р., м. Києву - 13,8\% у 2010 p. i 13,1\% у 2009 p. 3 аграрно-промислових i аграрних областей найвищі позиції за даним фактором займають Закарпатська обл. - 11 місце, 2,2\%, Сумська - 13 місце, 1,5\%, Вінницька - 16 місце, 1,1\% (табл. 1) [2].

На Чернівецьку обл. у 2010 р. припадають 0,2\% загального обсягу експорту товарів, що утричі менше від сусідньої Хмельницької обл. $(0,6 \%)$, у 4 рази - Житомирської обл. $(0,8 \%)$, в 11 разів - Закарпатської $(2,2 \%)$ і у понад 127 разів Донецької (25,5\%). 3 рис. 1-2 видно, що найбільше експортують східні, деякі центральні та деякі південні регіони.

У 2010 р. в порівнянні з 2009 р. суттєво покращили свою ситуацію відносно інших областей: Дніпропетровська обл. - на 2,5\% (3 $13,1 \%$ до 15,6\%) та Луганська обл. - на 1,7\% (3 $4,8 \%$ до 6,5\%). Значного зниження результатів зазнали м. Київ - на 3,4\% (з 17,2\% до 13,8\%) та Миколаївська обл. - на 0,8\% (3 3,9\% до 3,1\%). Доцільно підкреслити, що 54,9\% українського експорту товарів за 2010 р. (у 2009 р. - 53,8\%) реалізувалися трьома потужними промисловими регіонами-експортерами: Донецька i Дніпропетровська області та м. Київ. Тільки 45,1\% експорту товарів припадають на інші 24 регіони України.

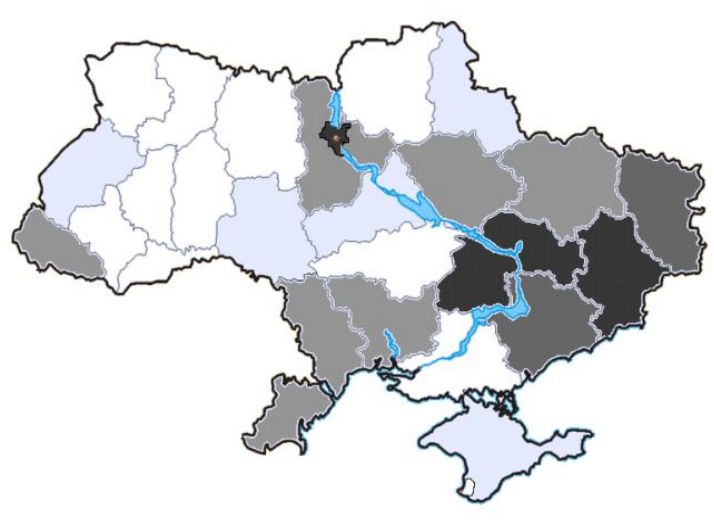

Рис. 1 Розподіл регіонів України за експортом товарів у \% до загального підсумку за 2009 р.
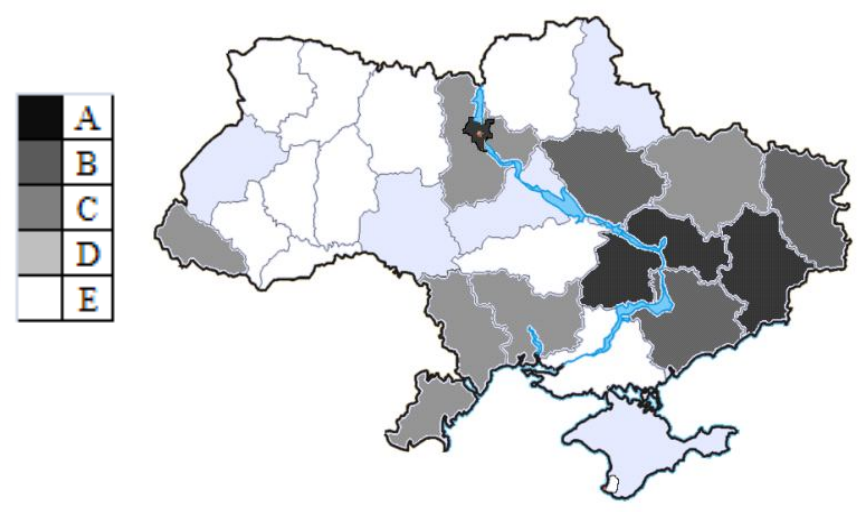

Рис. 2 Розподіл регіонів України за експортом товарів у \% до загального підсумку за 2010 р. 
Товарницька В. С.

Експорт та імпорт товарів на душу населення і у питомій вазі в розрізі регіонів України за 2009-2010 рр.

\begin{tabular}{|c|c|c|c|c|c|c|c|c|c|}
\hline \multirow[b]{3}{*}{ № } & \multirow[b]{3}{*}{ Область/Регіон } & \multicolumn{4}{|c|}{ Експорт товарів } & \multicolumn{4}{|c|}{ Імпорт товарів } \\
\hline & & \multicolumn{2}{|c|}{2009} & \multicolumn{2}{|c|}{2010} & \multicolumn{2}{|c|}{2009} & \multicolumn{2}{|c|}{2010} \\
\hline & & ПВ, \% & $\begin{array}{c}\text { дол. } \\
\text { США/ } \\
\text { чол. }\end{array}$ & ПВ, \% & $\begin{array}{c}\text { дол. } \\
\text { США/ } \\
\text { чол. }\end{array}$ & ПВ, \% & $\begin{array}{c}\text { дол. } \\
\text { США/ } \\
\text { чол. }\end{array}$ & $\begin{array}{c}\text { ПВ, } \\
\%\end{array}$ & $\begin{array}{c}\text { дол. } \\
\text { США/ } \\
\text { чол. }\end{array}$ \\
\hline 1. & АР Крим & 1,1 & 216,6 & 1,1 & 286,9 & 0,4 & 95,4 & 0,5 & 166,4 \\
\hline 2. & Вінницька & 1,2 & 290,2 & 1,1 & 345,1 & 0,6 & 159,3 & 0,6 & 210,3 \\
\hline 3. & Волинська & 0,8 & 307,7 & 0,8 & 419,2 & 0,9 & 412,6 & 0,9 & 551,9 \\
\hline 4. & Дніпропетровська & 13,1 & 1549,5 & 15,6 & 2404,3 & 7,9 & 1069,0 & 8,9 & 1614,8 \\
\hline 5. & Донецька & 23,5 & 2089,4 & 25,5 & 2961 & 4,3 & 433,4 & 5,1 & 692,0 \\
\hline 6. & Житомирська & 0,9 & 282,9 & 0,8 & 307,9 & 0,9 & 309,9 & 0,7 & 334,9 \\
\hline 7. & Закарпатська & 2,4 & 751,1 & 2,2 & 927,2 & 2,1 & 765,5 & 2,2 & 1081,1 \\
\hline 8. & Запорізька & 6,8 & 1499,6 & 6,2 & 1782,0 & 2,5 & 632,9 & 2,2 & 756,7 \\
\hline 9. & Івано-Франківська & 0,8 & 243,4 & 1,0 & 367,9 & 0,6 & 185,6 & 1,1 & 472,5 \\
\hline 10. & м. Київ & 17,2 & 2450,6 & 13,8 & 2538,2 & 45,2 & 7369,2 & 42,7 & 9267,3 \\
\hline 11. & Київська & 2,6 & 605,9 & 2,5 & 758,0 & 4,8 & 1262,3 & 5,0 & 1757,2 \\
\hline 12. & Кіровоградська & 0,6 & 246,9 & 0,7 & 333,5 & 0,3 & 145,5 & 0,3 & 185,6 \\
\hline 13. & Луганська & 4,8 & 816,1 & 6,5 & 1450,8 & 1,6 & 319,4 & 1,8 & 488,4 \\
\hline 14. & Львівська & 2,0 & 311,4 & 1,9 & 382,9 & 3,6 & 636,4 & 3,3 & 797,1 \\
\hline 15. & Миколаївська & 3,9 & 1288,3 & 3,1 & 1349,7 & 1,7 & 662,0 & 1,4 & 731,9 \\
\hline 16. & Одеська & 3,6 & 604,4 & 3,3 & 705,2 & 5,7 & 1087,8 & 5,8 & 1473,7 \\
\hline 17. & Полтавська & 3,8 & 843,2 & 4,3 & 1491,9 & 1,3 & 398,2 & 1,8 & 716,6 \\
\hline 18. & Рівненська & 3,2 & 279,9 & 0,8 & 344,1 & 0,6 & 224,5 & 0,7 & 380,1 \\
\hline 19. & м. Севастополь & 0,2 & 243,1 & 0,2 & 256,3 & 0,1 & 144,5 & 0,1 & 167,0 \\
\hline 20. & Сумська & 1,8 & 607,1 & 1,5 & 642,7 & 0,9 & 331,7 & 0,8 & 404,6 \\
\hline 21. & Тернопільська & 0,3 & 117,8 & 0,3 & 121,2 & 0,4 & 164,6 & 0,3 & 193,5 \\
\hline 22. & Харківська & 3,3 & 472,0 & 2,8 & 520,2 & 3,2 & 524,0 & 3,0 & 665,7 \\
\hline 23. & Херсонська & 0,9 & 321,3 & 0,7 & 322,0 & 0,3 & 114,1 & 0,3 & 148,1 \\
\hline 24. & Хмельницька & 0,6 & 184,6 & 0,6 & 219,7 & 0,6 & 206,6 & 0,8 & 346,2 \\
\hline 25. & Черкаська & 1,3 & 413,3 & 1,3 & 523,3 & 0,7 & 261,9 & 0,6 & 294,4 \\
\hline 26. & Чернівецька & 0,3 & 132,5 & 0,2 & 115,0 & 0,2 & 115,4 & 0,2 & 125,1 \\
\hline 27. & Чернігівська & 0,7 & 267,8 & 0,6 & 295,7 & 0,7 & 291,9 & $\overline{0,6}$ & 346,7 \\
\hline & Україна & 100,0 & 863,6 & 100,0 & 1123,5 & 100,0 & 988,5 & 100,0 & 1326,8 \\
\hline
\end{tabular}

За даними табл. 1 за ПВ у загальному обсязі імпорту товарів по Україні лідирують м. Київ 42,7\% у 2010 p. i 45,7\% у 2009 р., Дніпропетровська - 8,9\% у 2010 р. і 7,9\% у 2009 р. і Одеська області - 5,8\% у 2010 p. і 5,7\% у 2009 р. За дослідженим фактором найкращі результати належать промисловим та промислово-аграрним областям. 3 групи аграрних та аграрно-промислових найвищу позицію у рейтингу займає Закарпатська обл. - 8 місце, $2,2 \%$ у 2010 р. і $2,1 \%$ у 2009 р. 3 рис. 3-4 випливає, що переважну частку товарів імпортують східні регіони, Київська обл. та м. Київ, Одеська обл. і деякі західні регіони (Закарпатська та Львівська області).
Як за ПВ, так і за показником на душу населення, найбільшими експортерами товарів $\epsilon$ м. Київ, Дніпропетровська і Донецька області. У рейтингу за експортом товарів на душу населення лідерами є промислові регіони, переважно східні та деякі південні області України (рис. 5). Із західних регіонів найкращі результати показує Закарпатська обл. - 8 місце.

3 табл. 1 видно, що у 2010 р. відносно 2009 р. по всій Україні різко зросли показники експорту товарів на душу населення. Середній показник по Україні збільшився на 30,1\% - з 863,6 дол. США/ чол. до 1123,5 дол. США/чол. Значні зміни у сторону зростання відбулись у показниках 


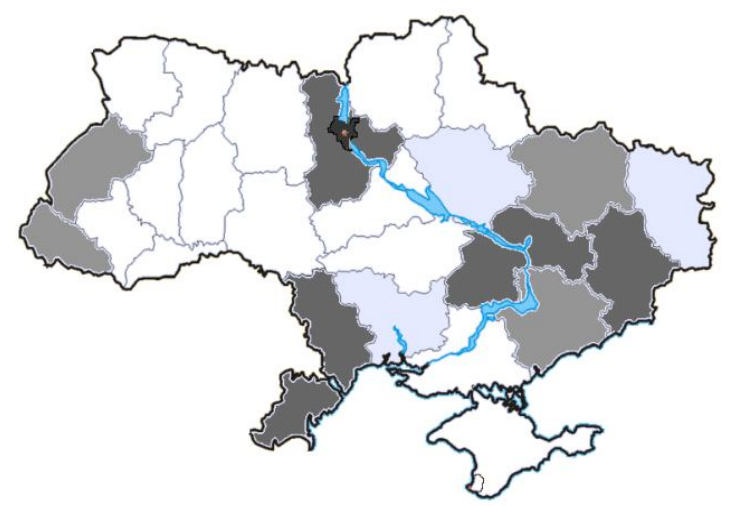

Рис. 3 Розподіл регіонів України за імпортом товарів у \% до загального підсумку за 2009 р.

Луганської обл. - 77,8\% (з 816,1 до 1450,8 дол. США/чол.) і Полтавської обл. - 76,9\% (з 843,2 до 1491,9 дол. США/чол.). Від'ємний темп приросту був зареєстрований лише у Чернівецькій обл. 13,2\% (з 132,5 до 115,0 дол. США/чол.).

Цікаво, що у сумі останні в рейтингу 11 областей експортують товари на душу населення на рівні Донецької обл. - 2961,0 дол. США/чол. Слід звернути увагу, що прикордонна Чернівецька обл., яка за аналізованим фактором займає останню позицію, зареєструвала показник (115,0 дол. США/чол.) у 2,5 рази менший АР Крим, у 6,1 рази - Одеської обл., у 8,1 разів - Закарпатської обл., у 20,9 разів - Дніпропетровської обл.

Лідерами рейтингу за імпортом товарів на душу населення є місто Київ (9267,3 дол. США/ чол.), Київська (1757,2 дол. США/чол.), Дніпропетровська $(1614,8$ дол. США/чол.) та Одеська області (1473,7 дол. США/чол.). Із аграрних регіонів найкращі результати показують Закарпатська та Волинська області - 1081,1 дол. США/чол. та 551,0 дол. США/чол. відповідно. Чернівецька обл. займає 27 позицію, упавши 325 позиції у 2009 р., з показником 125,1 дол. США/ чол. Сума останніх 8-ми регіонів у рейтингу за імпортом товарів на душу населення близька до результату Одеської обл., яка займає 4 місце, 1473,7 дол. США/чол.

Розглянувши табл. 1, можна помітити, що імпорт товарів на душу населення суттєво зріс в усіх регіонах. Середній показник по Україні збільшився на 34,2\% у 2010 р. в порівнянні з 2009 p. (3 988,5 до 1326,8 дол. США/чол.). Значні зміни у сторону зростання показали такі області як Івано-Франківська - на 154,7\% (з 185,6 до 472,5 дол. США/чол.) та Полтавська - на 79,9\% (з 398,2 до 716,6 дол. США/чол.). Найменші темпи приросту аналізованого показника мають Житомирська - 8,0\% (з 309,9 до 334,9 дол. США/

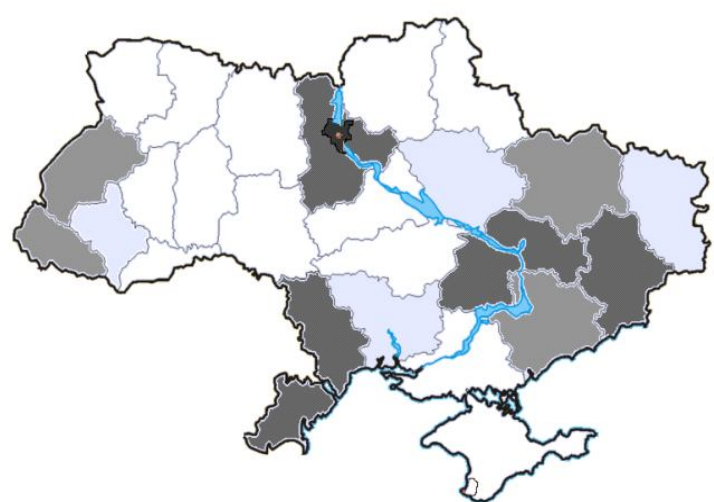

Рис. 4 Розподіл регіонів України за імпортом товарів у \% до загального підсумку за 2010 р. чол.) та Чернівецька області - 8,3\% (з 115,4 до 125,1 дол. США/чол.).

Розрахунки (табл. 1) та рис. 6 доводять, що найбільшими імпортерами товарів на душу населення $\epsilon$ більшість східних регіонів, деякі південні регіони - Одеська та Миколаївська області, центральні - Київська обл. та м. Київ, а також деякі західні регіони - Закарпатська та Львівська області.

Висновки та перспективи подальших досліджень. Як бачимо, три промислові регіони України, а саме Донецька і Дніпропетровська області та м. Київ, у 2010 р. реалізували 54,9\% експорту товарів (у 2009 р. - 53,8\%). Трійка лідерів також очолює рейтинг за експортом на душу населення. Водночас, 42,7\% імпорту товарів 2010 p. і 45,2\% 2009 р. припадає тільки на місто Київ. За результатами аналізу можемо констатувати, що зовнішньоекономічна динаміка регіонів визначається переважно товарними потоками, оскільки експорт послуг у структурі зовнішньої торгівлі для переважної більшості областей досить незначний. Дослідження продемонструвало, що в Україні досить чітко утримуються стійкі експортно-імпортні взаємозв'язки: області-найкрупніші експортери одночасно $\epsilon$ найбільшими імпортерами у країні. Розрахунки, здійснені нами, також вказують на значні відмінності в експортних спроможностях окремих областей України.

Як і кожна країна світу, Україна являє собою територіально-просторову сукупність окремих регіонів різного рівня, що мають стійкі зовнішні та внутрішні зв'язки, які перебувають у постійному русі. Регіони мають неоднорідний ресурсний потенціал і різну структуру економіки, що зумовлює відмінності в рівні життя населення України. Регіональні диспропорції мають місце в багатьох країнах світу, у тому числі й розвинених. 


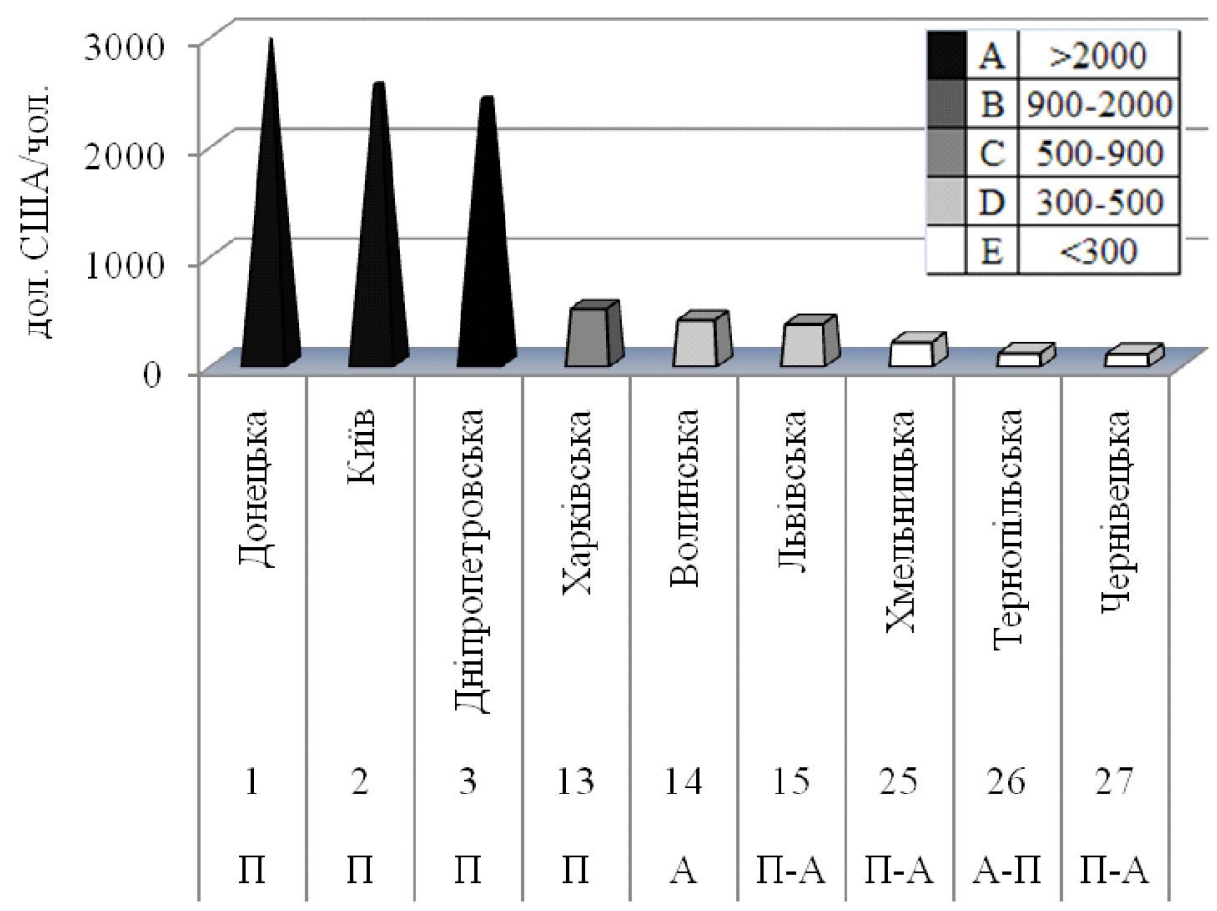

Рис. 5 Експорт товарів на душу населення у регіонах, які займають лідируючі, середні та найнижчі позиції, за 2010 р.

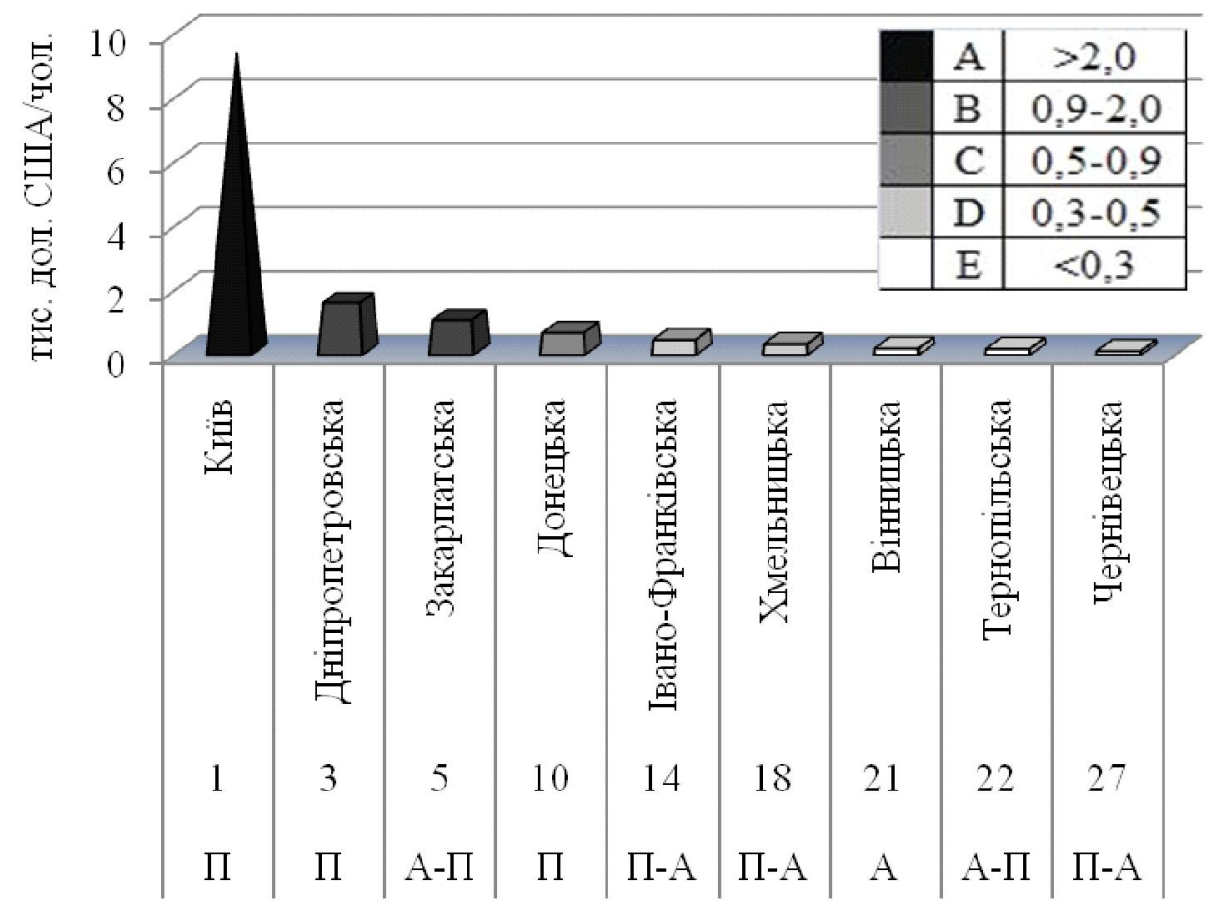

Рис. 6 Імпорт товарів на душу населення у різних регіонах за 2010 р.

Достатньо вказати істотно нижчі рівні економічного розвитку регіонів півдня Італії, півночі Великобританії, східних земель ФРН, низки районів Японії [3, с. 45].

Наявність суттєвого регіонального дисбалансу соціально-економічного розвитку ускладнює проведення єдиної політики соціально-економічних перетворень, формування загальнодержавного ринку товарів і послуг, збільшує загрозу регіональних криз, дезінтеграцію національної 
економіки. Регіональні диспропорції гальмують забезпечення високих темпів економічного зростання по всій території держави.

3 огляду на вищесказане, кожному регіону доводиться самостійно вибирати свій шлях розвитку, враховуючи низку факторів як зовнішнього, так і внутрішнього середовища. Виходячи 3 проведеного аналізу показників експорту та імпорту товарів 27-ми регіонів України за 2009-2010 рр., пропонуємо здійснити більш розширений аналіз системи внутрішніх і зовнішніх факторів формування конкурентоспроможності економіки України у регіональному розрізі та на основі отриманих результатів розробити поділ адміністративно-територіальних одиниць України на територіально-промислові райони, для кожного 3 яких визначити напрямки розвитку й удосконалення економічної діяльності.

Отже, спеціалізація та кооперація територіально-промислових районів створять міцний фундамент для зростання конкурентоспроможності національної економіки в цілому, що дасть змогу гідно конкурувати 3 іншими суб'єктами міжнародних економічних відносин на світових ринках.

Підсумовуючи наведене вище, зазначимо, що кожна країна складає свій набір конкурентних переваг, які дозволяють ій лідирувати в світовій економіці. Жодна країна у світі неспроможна бути однаково конкурентоспроможною в усіх галузях промисловості. Тому країни здобувають успіх на міжнародних ринках лише в тих галузях, для яких внутрішні умови виявилися найбільш сприятливими, динамічними і перспективними.

\section{Список літератури}

1. Мігай Н.Б. Розвиток потенціалу регіону як запорука підвищення його конкурентоспроможності. [Електронний pecypc]. - Режим доступу: www.ev.nuos.edu.ua/files/10mnbpyk.pdf

2. Державний комітет статистики України. [Електронний ресурс]. - Режим доступу: www.ukrstat.gov.ua

3. Романюк С. Конкурентоспроможність регіонів: теоретичні і практичні підходи // Національна безпека і оборона. - 2008. - №4. - C. 44-46.

\section{Аннотация}

Вероника Товарницкая

\section{АНАЛИЗ ПОКАЗАТЕЛЕЙ ЭКСПОРТА И ИМПОРТА ТОВАРОВ КАК ФАКТОРОВ ФОРМИРОВАНИЯ КОНКУРЕНТОСПОСОБНОСТИ ЭКОНОМИКИ УКРАИНЫ В УСЛОВИЯХ ГЛОБАЛИЗАЦИИ}

Подаеться аналитическая оценка некоторых внешних факторов формирования конкурентоспособности наџиональной экономики, а именно экспорта и импорта товаров Украины в региональном разрезе за 2009-2010 годы, поддерживая тезис о том, что ключевым звеном в решении вопроса конкурентоспособности страны является ее регионы. Автор обосновывает идею разделения административно-территориальных единии в территориально-промыщленные районы, способствующие повышению уровня конкурентоспособности национальной экономики в целом.

Ключевые слова: конкурентоспособность, конкурентоспособность национальной экономики, глобализация, конкурентоспособность региона, экспорт и импорт товаров.

\section{Summary}

Veronika Tovarnytska

\section{ANALYSIS OF INDICES OF EXPORT AND IMPORT OF GOODS AS FACTORS OF CREATION COMPETITIVENESS OF ECONOMY OF UKRAINE IN CONDITIONS OF GLOBALIZATION}

In this scientific article is given analytical appreciation of some external factors of creation national economy competitiveness, namely export and import of the goods of Ukraine in the regional breakdown for the years 2009-2010, supporting the thesis that the key part in solving the question of country's competitiveness is its regions. The author has substantiated the idea of division of administrative and territorial units into territorial and industrial zones, that will promote the increasing of the level of national economy competitiveness as a whole.

Key words: competitiveness, national economy competitiveness, globalization, region's competitiveness, export and import of the goods. 


\title{
ЕКОНОМІЧНА КІБЕРНЕТИКА
}

\author{
УДК 519.86 \\ (C) Піскунова О.В., 2011 \\ Державний вищий навчальний заклад «Київський національний економічний університет \\ імені Вадима Гетьмана», м. Київ
}

\section{ГНУЧКІСТЬ МАЛОГО ПІДПРИЕМСТВА ТА ЇЇ МОДЕЛЮВАННЯ}

Подано модель гнучкості малого підприємства, розроблену на підтрунті еволюиійної теорії економічних змін, яка враховує стохастичність ичін на вироблювану підприємством продукцію та очікування підприємщів щุодо майбутнього рівня циих иін. Проаналізовано гнучкість малих підприємств за різних схем оподаткування, різних механізмів формування очікувань та різного ступеня несхильності підприємиів до ризику.

Ключові слова: гнучкість підприємства, мале підприємство, моделювання, еволюиійна теорія економічних змін, пошук нових технологій.

Постановка проблеми. Сектор малого бізнесу $\epsilon$ дуже чутливим до дії несприятливих факторів, що негативно позначається на життєздатності малих підприємств, тобто на їх здатності продовжувати функціонування в умовах невизначеності та збурень зовнішнього i внутрішнього середовищ. Життєздатність підприємства суттєво залежить від його можливості, виходячи 3 інформації, отримуваної в процесі управління, цілеспрямовано змінювати свої параметри та структуру. Така зміна параметрів функціонування може відбуватись через інновації шляхом освоєння підприємством виробництва нових видів продукції або технологій їх виготовлення. Здатність підприємства щодо освоєння нових технологій або видів продукції характеризується гнучкістю підприємства [1]. За низької гнучкості можуть розвиватися дисфункції підприємства, пов'язані 3 його спробами підвищити життездатність, знижуючи якість вироблюваної продукції і тим знижуючи іiї собівартість, чи шляхом часткового ухиляння від сплати податків. Тому державна підтримка малого підприємництва, яка $є$ важливою умовою його розвитку, має бути спрямованою не тільки на створення умов для залучення в цей сектор економіки нових підприємців та утворення нових малих підприємств, але й на підвищення життєздатності та гнучкості вже існуючих підприємств. Для розробки ефективних програм підтримки малого бізнесу важливе значення має аналіз факторів, що впливають на гнучкість вітчизняних малих підприємств. Такий аналіз має спиратись на сучасні методи наукових досліджень, зокрема на методи економікоматематичного моделювання.

Аналіз останніх досліджень i публікацій та невирішені раніше частини загальної проблеми

У праці [1] представлено модель гнучкості підприємства $G n$ у вигляді 
функції від забезпеченості його ресурсами $\left(G C_{\mathrm{p}}\right)$ та здатності до оновлення $\left(G C_{\mathrm{OH}}\right)$. Зокрема тут розглядається така модель гнучкості підприємства: $G n=G n\left(G C_{\mathrm{p}}, G C_{\text {он }}\right)=G n\left[(\mathrm{~A}, \mathrm{BA}\right.$, РП, ЧП, $\left.\mathrm{H}), \quad\left(T_{\text {осв }}, T_{\text {вир }}, n\right)\right]$ , де А - активи підприємства за балансом; ВА - власні кошти; РП — обсяг продажу; ЧП - чистий прибуток; Н - частина прибутку, що направляється на освоєння нових виробів; $T_{\text {осв }}-$ середній період підготовки і освоєння нових виробів; $T_{\text {вир }}$ - середній період перебування виробів у виробництві та реалізації; $n$ - номенклатура виробів, які мають попит або можливо матимуть попит на ринку. Дана модель розроблена для великих машинобудівних підприємств, які здійснюють науководослідні і дослідно-конструкторські роботи (НДДКР). Водночас малі підприємства частіше за все не здійснюють НДДКР, а впроваджують у виробництво уже готові розробки. Для моделювання гнучкості таких підприємств можливе застосування еволюційної теорії економічних змін.

Базисну робочу концепцію еволюційної теорії утворюють застосовувані підприємствами правила прийняття рішень [2]. Якщо в ортодоксальній економічній теорії наявні та альтернативні технології $€$ заданими, а правила прийняття рішень $\epsilon$ наслідком максимізації прибутку підприємства, то тут те і друге трактується як відображення "рутин”, які історично склалися на даний момент часу i якими керуються підприємства. Керовані "рутинами" процеси зміни "рутин" моделюються як "пошук”. Складається формалізований опис характеристик популяції модифікацій "рутин”, які може виявити пошук, а тактика пошуку характеризується задаванням розподілу ймовірностей того, що буде знайдено в його результаті, як функцій від низки змінних.

Вважається за доцільне застосувати описаний підхід, запропонований еволюційною теорією, у моделюванні гнучкості вітчизняних малих підприємств, що функціонують в умовах ринкової економіки. При цьому як базову можна використовувати модель функціонування малого підприємства у дискретному часі, представлену у праці [3]. В цій моделі враховується, зокрема, стохастичність цін на вироблювану підприємством продукцію, яка, на наш погляд, може суттєво впливати на результати пошуку малим підприємством нових технологій та на його гнучкість. Крім того на умови пошуку може впливати механізм формування очікувань щодо рівня цін на вироблювану продукцію, оскільки завершення пошуку визначається не сьогоднішніми цінами, а саме очікуваними на майбутній період, коли буде реалізовуватись продукція, виготовлена за новою технологією.

Метою статті $є$ моделювання гнучкості малого підприємства на підгрунті еволюційної теорії 3 урахуванням стохастичності цін на вироблювану продукцію, а також з урахуванням очікувань щодо їх майбутнього рівня.

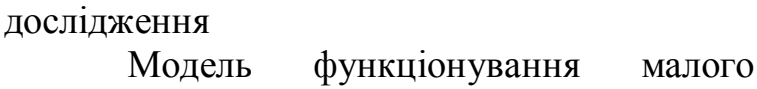
підприємства, у контексті якої розглядається його гнучкість, грунтується на таких припущеннях: основні виробничі фонди підприємства $A_{t-1}$ - це єдиний обмежуючий фактор, що визначає випуск продукції $X_{t}$ у момент часу $t: \quad X_{t}=f^{\prime} \cdot A_{t-1}$, де $f^{\prime}=$ const - коефіцієнт фондовіддачі (підприємство функціонує при незмінній технологіï). Вважається, що весь обсяг виробленої продукції $X_{t}$ реалізується на ринку за ціною $P_{t}$, а виручка від її реалізації дорівнює $V_{t}=P_{t} \cdot X_{t}$. Розрізняються використовувані виробничі фонди підприємства $A_{t}$ і наявні виробничі фонди $A_{t}^{*}: A_{t}=\varsigma_{t}^{*} \cdot A_{t}^{*}$, де $\zeta_{t}^{*}-$ коефіцієнт використання виробничих фонів. Чистий прибуток $F_{t}$ являє собою різницю між загальним прибутком $F_{t}^{3 a 2}=\left(1-c_{t}\right) \cdot V_{t}$ та сплаченим обсягом податків i зборів $N_{t}=\mathrm{v}_{t} \cdot V_{t}: \quad F_{t}=\left(1-c_{t}-\mathrm{v}_{t}\right) \cdot V_{t}$. Тут $v_{t}$ - агрегована ставка оподаткування підприємства: $v_{t}=\gamma_{t}-c_{t} \cdot \beta_{t}, \gamma_{t}$ і $\beta_{t}-$ 
параметри, значення яких залежать від обраної малим підприємством схеми оподаткування та діючих ставок податків [4], $c_{t}$ - собівартість виробництва та реалізації продукції на одиницю реалізованої продукції: $c_{t}=C_{t} / V_{t}, C_{t}$ - витрати на виробництво та реалізацію продукції без урахування податків та зборів.

Припускається, що обсяг витрат на виробництво одиниці продукції у фізичних одиницях та їх структура не змінюються у часі, а ціни на всі використовувані ресурси змінюються 3 часом однаково. Тоді питома собівартість продукції визначається наступним чином: $c_{t}=c_{0} \cdot \pi_{t}^{r e s} / \pi_{t}$. Тут $\pi_{t}$ - відношення ціни на продукцію підприємства у момент часу $t$ до ціни цієї продукції у початковий момент часу; $\pi_{t}^{r e s}$ відношення ціни будь-якого використовуваного ресурсу у момент часу $t$ до ціни цього ресурсу в початковий момент часу. Після нескладних перетворень можна отримати такий вираз для чистого прибутку: $F_{t}=\left(\pi_{t}-\pi_{t}^{r e s} \cdot c^{*}\right) \cdot\left(1-\gamma_{t}\right) \cdot f_{0} \cdot \varsigma_{t-1}^{*} \cdot A_{t-1}^{*}$, Де $c^{*}=c_{0} \cdot\left(1-\beta_{t}\right) /\left(1-\gamma_{t}\right)$, $f_{0}=f^{\prime} \cdot P_{0}$.

Підприємство може розвиватись за рахунок як внутрішніх джерел (отриманого прибутку $F_{t}$ ), так і зовнішньої фінансової підтримки $I_{t}:$ $\Delta A_{t}^{*}=A_{t}^{*}-A_{t-1}^{*}=\xi_{t} \cdot F_{t}+I_{t}$, де $\xi_{t} \in[0,1]$ - частка чистого прибутку, що відраховується малим підприємством на реінвестування (за умови отримання збитків підприємство виробничі фонди не нарощує). Зростання наявних виробничих фондів можна описати в такий спосіб: $\Delta A_{t}^{*}=\chi_{t} \cdot A_{t-1}^{*}+I_{t}$ $\chi_{t}=f_{0} \cdot\left(1-\gamma_{t}\right) \cdot\left(\pi_{t}-\pi_{t}^{r e s} \cdot c^{*}\right) \cdot \xi_{t} \cdot \varsigma_{t}^{*}$, звідки $A_{t}^{*}=\left(1+\chi_{t}\right) \cdot A_{t-1}^{*}+I_{t}$.

Джерело невизначеності в моделі випадкові ціни на продукцію підприємства та використовувані ресурси. припускати, що ціни на вироблювану продукцію змінюються: $\pi_{t}=1+\varepsilon_{t}$, де $\varepsilon_{t}$ випадкові, незалежні між собою величини 3 нульовим математичним сподіванням. Водночас припускатимемо, що ціни на використовувані ресурси постійні у часі: $\pi_{t}^{r e s}=1$, якщо $t<t^{\prime}$, але у деякий момент $t^{\prime}$ вони підвищуються: $\pi_{t}^{r e s}=\pi^{r}\left(\pi^{r}>1\right)$, якщо $t>t^{\prime}$.

3 формули (1) витікає умова невід'ємності чистого прибутку підприємства до підвищення цін на ресурси:

$$
c^{*}=c_{0} \frac{1-\beta_{t}}{1-\gamma_{t}} \leq \pi_{t}=1+\varepsilon_{t}, t \leq t^{\prime}
$$

Після підвищення цін на ресурси умова невід'ємності прибутку набуде такого вигляду:

$$
\begin{gathered}
c^{\prime *}=c_{0} \frac{1-\beta_{t}}{1-\gamma_{t}} \pi^{r}=c_{0}^{\prime} \frac{1-\beta_{t}}{1-\gamma_{t}} \leq \pi_{t}=1+\varepsilon_{t}, \\
t>t^{\prime},
\end{gathered}
$$

де $c_{0}^{\prime}=c_{0} \cdot \pi^{r}$. Порівнюючи формули (2) $\mathrm{i}$ (3), бачимо, що в останньому ви(1)дку суттєво підвищується ймовірність отримання підприємством збитків.

Як приклад розглянемо динаміку малого підприємства за нормально розподілених випадкових величин $\varepsilon_{t} \sim N\left(0, \sigma_{\varepsilon}\right)$. Візьмемо для визначеності, що $f_{0}=0,25 ; c_{0}^{\prime}=0,95 ; \sigma_{\varepsilon}=0,25 ;$ не будемо враховувати в моделі нарощування виробничих фондів: $\xi_{t} \equiv 0$; крім того припустимо, що за отримання збитків виробничі фонди використовуються тільки наполовину: $\varsigma_{t}^{*}=0,5$, якщо $F_{t}<0$, i $\zeta_{t}^{*}=1$, якщо $F_{t} \geq 0$. На рис. 1 показано динаміку математичних сподівань відносних прибутків (збитків) підприємства $M\left(\sum_{\tau=1}^{t} F_{\tau} / A_{0}\right)$,розрахованих наростальним підсумком за різних схем оподаткування (малі підприємства можуть обирати або загальну систему оподаткування - схема 1, або спрощені: за ставкою $6 \%$ від обсягу 
реалізації зі сплатою ПДВ - схема 2, чи за ставкою $10 \%$ без сплати ПДВ - схема 3 [4]). Як бачимо з рис.1, за розглянутих параметрів функціонування системи математичне сподівання сумарного відносного прибутку підприємства буде від'ємним, тому період його функціонування у такому стані досить обмежений. Так, математичне сподівання величини накопичених відносних збитків підприємства перевищить величину 5\% за загальної схеми оподаткування вже у момент часу $t=2$, за схеми $2-$ у момент часу $t=4$, за схеми 3 - у момент часу $t=6$.

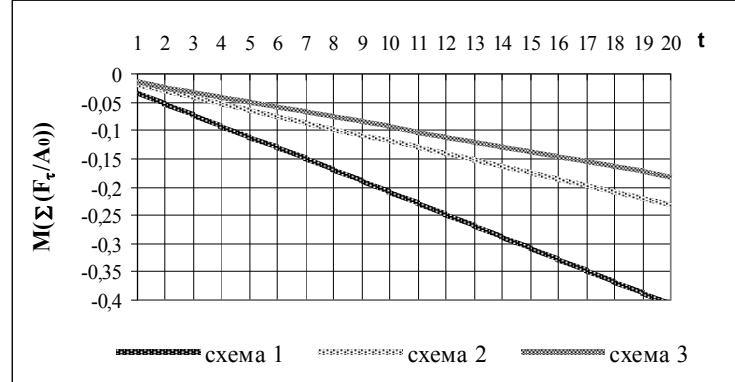

\section{Рис. 1. Математичне сподівання відносних прибутків (збитків) підприсмства, обрахованих наростальним підсумком}

\begin{abstract}
Марківська модель пошуку підприємством нових технологій виробництва. Після підвищення цін на використовувані ресурси i, як наслідок, підвищення ризику отримання збитків підприємство може або одразу припинити свою діяльність, або, реагуючи на зміни ринкової кон'юнктури, розпочати пошук нових більш дешевих технологій.
\end{abstract}

Вважатимемо, що кожна технологія характеризується питомою собівартістю, водночас для всіх технологій $f^{\prime}=$ const. Поки підприємство не знайшло та не впровадило нову технологію $c_{0}^{\prime \prime}$, воно функціонує за старої технології $c_{0}^{\prime}$. Розрізнятимемо розглядувану (обстежувану) у момент часу $t$ технологію $\widetilde{c}_{u_{t}}$, знайдену на момент часу $t$ технологію $c_{u_{t}}$ i впроваджувану технологію $c_{0}^{\prime \prime}$. Пошук підприємства полягає в дослідженні деякої альтернативної технології 3 розподілу множини альтернативних технологій $\widetilde{c}_{u_{t}}$ в околі деякої переважаючої технології. Якщо знайдено технологію $\widetilde{c}_{u_{t}}$, що задовольняє умові на зниження витрат, то знайдена на момент часу $t$ технологія $c_{u_{t}}$ замінюється на цю альтернативну технологію $\widetilde{c}_{u_{t}}$, у протилежному разі знайдена технологія залишається такою ж самою. Знайдена на момент часу $t$ технологія $c_{w_{t}}$ впроваджується у виробництво за такої умови:

$$
c_{u_{t}}^{*} \leq \pi_{t+1}^{e}-\Delta c_{\kappa p},
$$

Де $c_{u_{t}}^{*}=c_{u_{t}} \cdot\left(1-\beta_{t}\right) /\left(1-\gamma_{t}\right) ; \pi_{t+1}^{e} \quad-$ очікування щодо рівня цін на продукцію підприємства у момент часу $(t+1)$; $0<\Delta c_{\kappa p}<1 \quad$ - деяке мінімальне перевищення питомої собівартості продукції за застосовуваної технології над питомою собівартістю за впроваджуваної технології, за якого підприємець погоджується впроваджувати нову технологію. Наявність у формулі (4) величини $\Delta c_{\kappa p}$ зумовлена тим, що впровадження нової технології пов'язане 3 додатковими затратами та додатковими ризиками. Пошук закінчується впровадженням знайденої технології, тобто переходом від $c_{0}^{\prime}=c_{0} \cdot \pi^{r}$ до $c_{0}^{\prime \prime}=c_{u_{t}}$, де технологія $c_{u_{t}}$ задовольняє умову (4). Звернемо увагу на те, що в умові (4) розглядається не відносний рівень цін на вироблювану продукцію $\pi_{t}$, а очікуваний $\pi_{t+1}^{e}$. Таке припущення виглядає досить природним, оскільки за нової технології підприємство функціонуватиме не у теперішній період часу, а лише у наступні.

$$
\text { Розглядатимемо впорядковану }
$$
множину можливих технологій, що включає скінчену сукупність значень $c_{u}$, пронумерованих від 1 до $S$. Тобто можливі технології розрізняються за своїми значеннями на ціле кратне константи $\Delta c_{w}$ 
( $\Delta c_{u}$ - довільна). Нехай $c_{u}^{1}, c_{u}^{2}, \ldots, c_{u}^{s} \epsilon$ різними можливими значеннями $c_{w}$. Під технологією $i$ будемо розуміти технологію, що характеризується питомою собівартістю $c_{u}^{i}=c_{u}^{0}-i \cdot \Delta c_{u}$, де $c_{u}^{0}$ - константа відносно котрої оцінюється діапазон змін розглядуваних значень $c_{u}^{i}$, а величина $\Delta c_{u}$ відповідає пропорційній різниці між суміжними значеннями $c_{u}^{i}$ в даній упорядкованій множині. Опишемо тепер схему пошуку. Нехай $i-$ знайдена технологія підприємства в момент часу $t$. Результат пошуку визначається випадковим цілим числом $G_{t}$, котре по суті є кількістю кроків, зроблених підприємством дЛЯ вимірів $c_{u}$ за обмеженням, що $c_{u}$ може варіювати лише між $c_{u}^{1}$ та $c_{u}^{s}$ [2]:

$$
\widetilde{c}_{u_{t+1}}=\left\{\begin{array}{lll}
c_{u}^{i+G_{t}}=c_{u}^{0}-\left(i+G_{t}\right) \cdot \Delta c_{u}, & \text { якщо } & 1<i+G_{t}<s \\
c_{u}^{1}=c_{u}^{0}-\Delta c_{u}, & \text { якщуо } & i+G_{t} \leq 1 ; \\
c_{u}^{s}=c_{u}^{0}-s \cdot \Delta c_{u}, & \text { якщ̧о } & i+G_{t} \geq s .
\end{array}\right.
$$

Випадкову змінну $G_{t}$ вважатимемо незалежною від $c_{u_{t}}$ та від усіх попередніх значень $c_{u_{t}}$, а також у часі. Якщо технологія $\widetilde{c}_{u_{t+1}}$, отримана в результаті пошуку, витримує тест на зниження витрат: $\widetilde{c}_{u_{t}}<c_{u_{t}}, \quad$ то $\quad c_{u_{t+1}}=\widetilde{c}_{u_{t+1}}$. $\mathrm{У}$ протилежному випадку $c_{u_{t+1}}=c_{u_{t}}$. Ця схема пошуку й тестування визначає розподіл умовних імовірностей технологій на період $(t+1)$ за умови технології в період $t$, i цей розподіл залежить від розподілу $G_{t}$ (припускається, що ймовірність «накопичується» на граничних значеннях $c_{u}^{1}$ i $\left.c_{u}^{s}\right)$. І Із зроблених припущень щодо незалежності випливає, що послідовність технологій, яку підприємство застосовує в часі, утворює марківський ланцюг. $\begin{array}{cccr}\text { Tехнології підприємства } & \text { можна } \\ \text { описати } & \text { матрицею } \mathbf{p} & \text { перехідних }\end{array}$ імовірностей розмірністю $(s \times s)$ : $\mathbf{p}=\left[p_{k i}\right], \quad k, i=\overline{1, s}, \quad$ де $\quad$ стан $i$ асоціюється 3 технологією $i$, а $p_{k i}$ імовірність того, що стан $i$ настане після стану $k$. Ця матриця вважається постійною в часі. Властивість матриці $\mathbf{p}$ полягає в тому, що ії рядки упорядковані за співвідношенням $\sum_{i=1}^{n} p_{K i} \leq \sum_{i=1}^{n} p_{k i}$

якщо

$n, k=1, \ldots, s-1 ; K>k$. Тобто умовна ймовірність переходу до стану 3 меншим номером зі стану з більшим номером менша, ніж та сама ймовірність за умови переходу зі стану 3 меншим номером. Ця властивість відповідає економічній ідеї про «локальність» пошуку [2].
Якщо відомі ймовірності $p_{c_{0}}^{i}$ кожного стану $i$ системи в початковий момент часу $t=0$, то за рекурентною формулою можна визначити безумовні ймовірності $p_{c_{0}}^{i}$ знаходження системи на будь-якому кроці $t$ у стані $i \quad$ [5]: $p_{c_{t}}^{i}=\sum_{j=1}^{s} p_{c_{t-1}}^{j} \cdot p_{j i}$.

Пошук закінчується успішно, якщо знайдена технологія $c_{u_{t}}$ задовольняє умову (4). Як бачимо 3 (4), момент успішного закінчення пошуку нової технології та іiі впровадження залежить від механізму формування очікувань підприємців щодо майбутнього рівня цін на продукцію підприємства. У сучасній економічній науці, як правило, виокремлюють три типи очікувань: статичні, адаптивні й раціональні [4]. У нашому випадку, коли ціни на 
продукцію підприємства змінюються за формулою $\pi_{t}=1+\varepsilon_{t}$, очікування щодо майбутнього відносного рівня цін моделюються наступним чином: статичні очікування - $\pi_{t+1}^{e}=\pi_{t}=1+\varepsilon_{t}$; адаптивні очікування - $\pi_{t+1}^{e}=\lambda \cdot \sum_{\tau=0}^{t}(1-\lambda)^{\tau} \cdot \varepsilon_{t-\tau}$, де $\varepsilon_{0}=0, \quad 0 \leq \lambda \leq 1$ - коефіцієнт адаптації, який враховує помилки минулих оцінок (статичні очікування можна розглядати як окремий випадок адаптивних очікувань, коли $\lambda=1)$; раціональні очікування $\pi_{t+1}^{e}=1+M\left(\varepsilon_{t+1}\right) \equiv 1$.

За статичних очікувань, якщо випадкові величини $c_{u_{t}}$ i $\varepsilon_{t}$ розподілені незалежно, безумовну ймовірність $p_{t}$

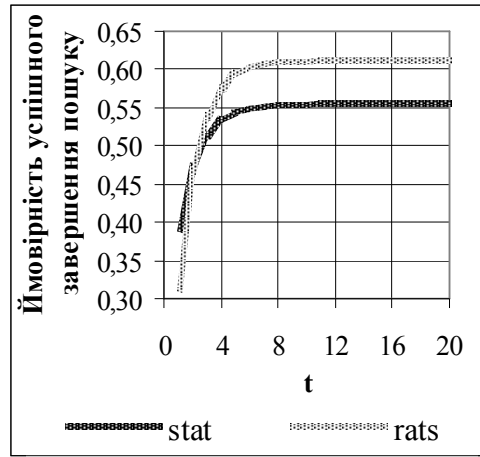

CXEMA 1

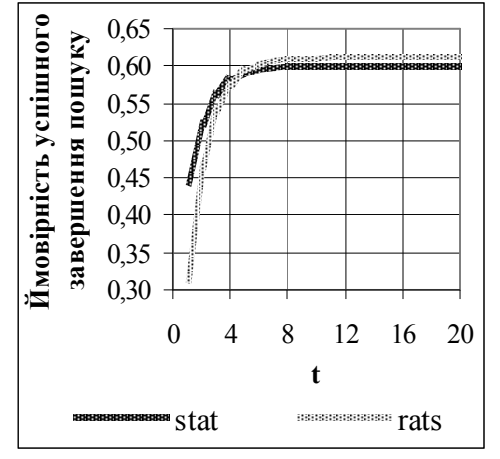

CXEMA 2

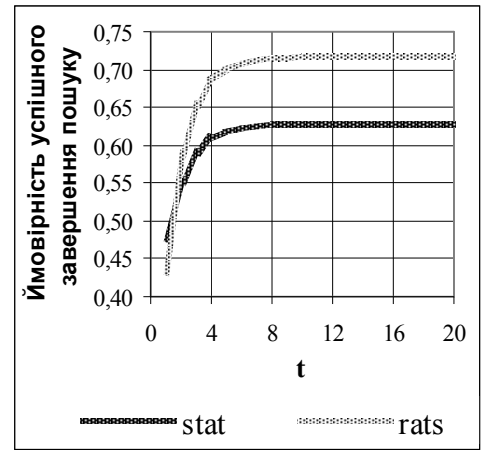

CXEMA 3

Рис. 2. Безумовні ймовірності успішного завершення пошуку нової технології на кроці $t$ за різних схем оподаткування успішного закінчення пошуку на кроці $t$ можна обчислити так: $p_{t}=\sum_{i=1}^{s} p_{c_{t}}^{i} \cdot p_{\varepsilon}^{i}, \quad$ де $\quad p_{\varepsilon}^{i} \quad$ - умовна ймовірність успішного завершення пошуку за знайденої технології $c_{u_{t}}=c_{u}^{i}$. Зокрема, для нормально розподілених випадкових величин $\varepsilon_{t} \sim N\left(0, \sigma_{\varepsilon}\right)$ імовірність $p_{\varepsilon}^{i}$ дорівнює $p_{\varepsilon}^{i}=\frac{1}{2}+\Phi\left(\frac{c^{*_{i}}-1+\Delta c_{\kappa p}}{\sigma_{\varepsilon}}\right), \quad$ де $c^{i^{*}}=c^{i} \cdot\left(1-\beta_{t}\right) /\left(1-\gamma_{t}\right), \Phi(\bullet)$ - функція лапласа або «інтеграл ймовірностей»: $\Phi(x)=\frac{1}{\sigma_{\varepsilon} \sqrt{2 \pi}} \cdot \int_{0}^{x} e^{-\frac{x^{2}}{2 \sigma_{\varepsilon}^{2}}} d x$.

завершення підприємством пошуку нової технології на кроці $t$ за різних схем
За раціональних очікувань момент успішного завершення пошуку визначається умовою $c_{u}^{i} \leq\left(1-\Delta c_{\kappa p}\right) \cdot\left(1-\beta_{t}\right) /\left(1-\gamma_{t}\right)$, тобто пошук закінчується, якщо знайдено якусь технологію з номером $i \geq i_{\kappa p}$, де $i_{\kappa p}$ найменший номер стану, для якого вже виконується дана умова. У цьому разі безумовна ймовірність $p_{t}$ успішного закінчення пошуку на кроці $t$ обчислюється так: $p_{t}=\sum_{i=i_{\kappa p}}^{s} p_{c_{t}}^{i}$.

На рис. 2 показано динаміку безумовних імовірностей успішного оподаткування у випадку статичних (лінія stat) та раціональних (лінія rats) 
очікувань. Припускалося, що технології, серед яких здійснюється пошук, характеризуються такими параметрами: $c^{0}=0,95, \quad \Delta c_{u}=0,05, \quad s=11 . \quad$ В початковий момент система знаходиться у стані $i=0: \quad p_{c_{0}}^{0}=1, \quad p_{c_{0}}^{i}=0, i=\overline{1, s}$. Матрицю $\mathbf{p}$ побудовано так, щоб виконувалась умова «локальності» пошуку.

Як видно 3 рис.2, в перші періоди пошуку ймовірність його успішного завершення вища за статичних очікувань, але через декілька зроблених кроків, більш висока ймовірність впровадження нової технології буде вже за раціональних очікувань.

Як показник гнучкості малого підприємства можна розглядати безумовну ймовірність успішного завершення пошуку у момент часу, що відповідає деякому критичному значенню накопичених підприємством збитків при функціонуванні за старої технології. У табл. 1 наведені безумовні ймовірності успішного завершення пошуку у той момент часу $t^{*}$, коли математичне сподівання накопичених відносних збитків підприємства, функціонуючого за технології $c_{0}^{\prime}$, перевищить 5\%. Розрахунки виконано для різних схем оподаткування та різних значень $\Delta c_{\kappa p}$ за статичних (stat) I раціональних ( rats ) очікувань.

Безумовні ймовірності успішного завершення пошуку нової технології за різних схем оподаткування та різних параметрів умови завершення пошуку

\begin{tabular}{|c|c|c|c|c|c|c|c|}
\hline \multirow{2}{*}{$\begin{array}{c}\text { Схеми } \\
\text { оподатку- } \\
\text { вання } \\
\end{array}$} & \multirow{2}{*}{$\begin{array}{l}\text { Очіку- } \\
\text { вання }\end{array}$} & \multirow{2}{*}{$t^{*}$} & \multicolumn{5}{|c|}{ Ймовірності успішного завершення пошуку } \\
\hline & & & $\Delta c_{\kappa p}=0,25$ & $\Delta c_{\kappa p}=0,2$ & $\Delta c_{\kappa p}=0,15$ & $\Delta c_{\kappa p}=0,1$ & $\Delta c_{\kappa p}=0,05$ \\
\hline \multirow[t]{2}{*}{ 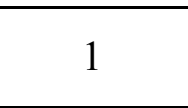 } & stat & \multirow{2}{*}{2} & 0,35 & 0,41 & 0,47 & 0,54 & 0,60 \\
\hline & rats & & 0,25 & 0,35 & 0,47 & 0,59 & 0,59 \\
\hline \multirow{2}{*}{2} & stat & \multirow{2}{*}{4} & 0,45 & 0,52 & 0,58 & 0,64 & 0,70 \\
\hline & rats & & 0,46 & 0,46 & 0,57 & 0,69 & 0,79 \\
\hline \multirow{2}{*}{3} & stat & \multirow{2}{*}{6} & 0,49 & 0,56 & 0,62 & 0,68 & 0,74 \\
\hline & rats & & 0,49 & 0,60 & 0,71 & 0,81 & 0,89 \\
\hline
\end{tabular}

Аналіз табл.1 показує, що найбільш гнучким мале підприємство буде за схеми оподаткування 3: у цьому разі за всіх значень $\Delta c_{\kappa p}<0,25$ ймовірність впровадження нової технології буде не меншою, ніж 0,6. Величина $\Delta c_{\kappa p}$ визначається, певною мірою, несхильністю підприємця до ризику: чим менше той схильний до ризику, тим більшим буде значення цієї величини, водночас суттєво знижується гнучкість підприємства. Так, якщо $\Delta c_{\kappa p}=0,25$, то за всіх розглядуваних схем оподаткування у моменти часу, коли накопичені збитки перевищать 5\%, ймовірність успішного завершення пошуку буде менше 0,5 . досліджень

Висновки та перспективи подальших

Як показав проведений аналіз, в перші періоди пошуку ймовірність його успішного завершення вища за статичних очікувань, але вже через декілька зроблених кроків, більш висока ймовірність впровадження нової технології буде вже за раціональних очікувань. Як показник гнучкості малого підприємства запропоновано розглядати безумовну ймовірність успішного завершення пошуку у момент часу, що відповідає критичному значенню накопичених підприємством збитків при його функціонуванні за старої технології. Отримано, що найбільш гнучким мале підприємство буде у разі застосування спрощених схем оподаткування. Крім того, 
гнучкість підприємства суттєво знижується, якщо підприємець не схильний до ризику.

\section{Список літератури}

1. Самочкин В. Н. Гибкое развитие предприятия: Анализ и планирование. - М.: Дело, 2000. - 376 с.

2. Нельсон Р., Уинтер С. Эволюционная теория экономических изменений: Пер. с англ. М.Я. Каждана. М.: ЗАО «ФИНСТАТИНФОРМ», 2000. $474 \mathrm{c}$.

3. Піскунова О.В. Системні характеристики управлінських рішень у моделюванні динаміки малого підприємства // Моделювання та інформаційні системи в економіці. Зб. наук. праць. - Київ: КНЕУ, 2011.- Вип. 83. - C. 220-236.

4. Вітлінський В.В., Піскунова О.В. Математичні моделі та методи ринкової економіки: Навч. посібник. - К.: КНЕУ, 2010. - $531 \mathrm{c}$.

5. Вентцель Е. С., Овчаров Л. А. Теория случайных процессов и ее инженерное приложение. Учеб. пособие для втузов. - М.: Высш. шк., 2000. - 383 с.

\section{Аннотация}

Елена Пискунова

\section{ГИБКОСТЬ МАЛОГО ПРЕДПРИЯТИЯ И ЕЕ МОДЕЛИРОВАНИЕ}

Представлена модель гибкости малого предприятия, разработанная на основе эволючионной теории экономических изменений, которая учитывает стохастичность иен на изготавливаемую предприятием продукиию и ожидания предпринимателей относительно будущего уровня этих иен. Проанализирована гибкость мальх предприятий при различных схемах налогообложения, различных механизмах формирования ожиданий и различной степени несклонности предпринимателей к риску.

Ключевые слова: Гибкость предприятия, малое предприятие, моделирование, эволюиионная теория экономических изменений, поиск новых технологий.

\section{Summary \\ SMALL ENTERPRISE FLEXIBILITY AND ITS MODELLING}

The model of small enterprise flexibility, which developed on the basis of economic change evolutionary theory, is represented. This model allows stochasticity of price and expectations about price level. Small enterprise flexibility for different systems of taxation, different types of expectations and different unpropensity of entrepreneur to risk is researched.

Keywords: Enterprise flexibility, small enterprise, modelling, evolutionary theory of economic change, search of new technology. 


\section{СИСТЕМНИЙ ПІДХІД В АВТОМАТИЗАЦІЇ СИСТЕМИ УПРАВЛІННЯ ПІДПРИЕМСТВОМ}

Стаття присвячена виявленню особливостей та переваг використання системного підходу як такого, щуо забезпечить базис для ефективного управління за допомогою автоматизачії системи управління підприємств. Досліджено особливості системного підходу, охарактеризовано переваги використання системного підходу в аналізі й обробчі інформації на основі комплексної автоматизації підприємства, визначено перешкоди, щзо виникають на шляху впровадження системного управління автоматизацією підприємства.

Ключові слова: системний підхід, принципи системного підходу, системний підхід в управлінні підприємством; системний підхід в автоматизащії системи управління підприємством.

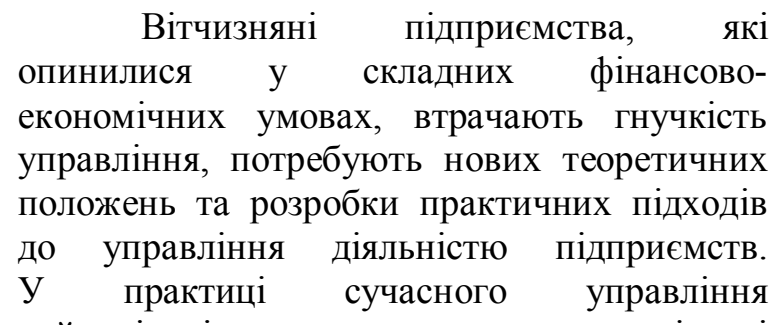
найдоцільніше використовувати управлінські методи і технології, зокрема системний підхід, процесно-орієнтоване управління, управлінський облік, методи стратегічного управління, бюджетування тощо. Зокрема, системний підхід в управлінні дає можливість розглядати підприємство як складну організаційну систему, а також вдосконалювати управлінську діяльність на основі комплексної автоматизації системи управління підприємством.

Питанням системного підходу в управлінні підприємством приділялося багато уваги вченими-економістами, серед яких можна виділити Оптенера С.Л., О'Коннора Дж., Волкову В.М., Смєльянова О.А., Анфілатова В.С., Іванову M.І., Турлакову С.С., Ігнатьєва А.В., Катренко А.В. і т.д. Проте, незважаючи на цілий ряд наукових праць, які розкривають деякі аспекти системного підходу в управлінні, питання використання системного підходу в автоматизації системи управління підприємством за своєю сутністю ще повністю не розкриті, потребують подальшого розвитку i $€$ завжди актуальними.

Метою статті $є$ виявлення особливостей та переваг використання системного підходу як такого, що забезпечить базис для ефективного управління за допомогою автоматизації системи управління підприємствами. Пропонується дослідити особливості системного підходу, охарактеризувати переваги використання системного підходу в аналізі й обробці інформації на основі комплексної автоматизації підприємства, визначити перешкоди, що виникають на шляху впровадження системного управління автоматизацією підприємства.

Перш за все, перед описом основних рис системного підходу i його місця в процесі автоматизації системи управління підприємства, зупинимося детальніше на класичному розумінні системного підходу [1$6]$.

Системний підхід - це категорія, що не має єдиного визначення, оскільки трактується неоднозначно різними вченими. Наприклад, системний підхід можна розглядати як один із головних напрямків методології спеціального наукового пізнання 
та соціальної практики, мета і завдання якого полягають у дослідженнях певних об'єктів як складних систем. Системний підхід сприяє формуванню відповідного адекватного формулювання суті досліджуваних проблем у конкретних науках i вибору ефективних шляхів їх вирішення [1].

Григорків В.С. зазначає, що основним підходом до розв'язання сучасних кібернетичних проблем $є$ системний підхід, зміст якого полягає в комплексному й всеохоплюючому вивченні об'єкта дослідження як окремої цілісної системи (або підсистеми) [2].

Методологічна специфіка системного підходу полягає в тому, що метою дослідження $\epsilon$ вивчення закономірностей i механізмів утворення складного об'єкта 3 певних складових. При цьому особлива увага приділяється різноманіттю внутрішніх i зовнішніх зв'язків системи, процесам (процедурам) об'єднання основних понять у єдину теоретичну картину, що дає змогу виявити сутність цілісності системи.

Отже, системним підходом можна назвати сукупність методологічних принципів i теоретичних засад, які дають можливість розглядати кожний елемент системи в його зв'язку і взаємодії з іншими елементами; простежити зміни, які відбуваються в системі в результаті зміни окремих ii ланок; вивчати специфічні системні властивості; формулювати обгрунтовані висновки про закономірності іiі розвитку; визначати оптимальний режим функціонування тощо.

Використання системного підходу для управління різними системами грунтується на принципах системного підходу, які є загальними положеннями, що відображають відношення, абстраговані від конкретного змісту наукових i прикладних проблем. Для розв язання конкретної наукової проблеми або проблемної ситуації принципи системного підходу повинні конкретизуватися, причому конкретизація визначається об'єктом i предметом дослідження. В дослідженні складних систем необхідно виявити суттєві особливості проблеми, врахувати найважливіші взаємозв'язки на основі інтерпретації системних принципів до конкретних умов, що дає змогу досліднику піднятися на вищий рівень розуміння системи загалом, вийти за межі iï розгляду «зсередини». При дослідженні різних систем адекватне застосування принципів системного підходу сприяє розвитку системного мислення дослідника.

Принципи системного підходу не тільки формулюють вимоги до систем, але й узагальнюють досвід роботи людей зі складними системами [1-4]:

1. Принцип остаточної мети. Система існує та функціонує для досягнення основної (глобальної) мети, яка має абсолютний пріоритет.

2. Принцип єдності. Сдність відображає погляд на систему «ззовні», тобто погляд на цілісну структуру.

3. Принцип зв'язності. Зв'язність характеризує погляд на систему «зсередини» та конкретизує систему як сукупність взаємозв'язаних елементів, підсистем i відношень між ними. Будь-яка компонента системи аналізується разом із їі зв'язками та локальним оточенням.

4. Принцип модульності. Зміст цього принципу полягає в доцільності інколи розглядати систему як взаємозв'язану сукупність модулів (складових різного ступеня загальності), якщо це дозволяє уникнути зайвої деталізації й зберегти адекватний опис системи.

5. Принцип ієрархії. Зручність дослідження систем часто залежить від природної та штучної (створеної) ієрархії зв'язків між елементами, модулями, цілями.

6. Принцип функціональності. Створювати або корегувати структуру системи можна тільки після з'ясування іiі функцій. У разі надання системі нових функцій також потрібно переглянути іï структуру.

7. Принцип розвитку. При вивченні системи обов'язково потрібно врахувати можливості їі зміни, розширення, заміни складових, вдосконалення, нагромадження інформації.

8. Принцип децентралізації. У системі все повинно бути підпорядковано меті, тому між централізацією й децентралізацією має існувати розумний компроміс, зміст якого полягає в наданні складовим системи певних можливостей для прийняття самостійних рішень і здатності реагувати на зовнішні впливи. 
9. Принцип невизначеності. При визначенні стратегії й тактики розвитку системи обов'язково треба враховувати невизначеності та випадковості, що впливають на систему й можуть суттєво перешкодити досягненню системою іiі глобальної мети.

У багатьох випадках інтерпретація системних принципів в конкретних умовах дозволяе піднятися на новий рівень розуміння системи загалом, вийти за межі розгляду iii «зсередини» [7]. Зазначимо, що практичне застосування основних принципів системного підходу до конкретної проблеми позв'язано 3 ii детальним уточненням та реальним змістовим навантаженням. Крім того, іiі реалізація істотно залежить від знань, майстерності та системоаналітичного досвіду дослідника.

При цьому, як показують дослідження та практика управління підприємств, однією з основних причин, що гальмують розвиток бізнесу, $є$ відсутність ефективних методів управління, заснованих на використанні сучасних інформаційних технологій та одночасному застосуванні системного підходу. Ці обставини зумовлені специфікою конкурентного середовища, в якій функціонує підприємство, а також особливостями ведення бізнесу в умовах інформатизації та глобалізації суспільства [7, 8]

Методологічна специфіка системного підходу визначається тим, що він зорієнтований на розкриття цілісності об'єкта та механізмів, що її забезпечують; на виявлення численних типів зв'язків $\mathrm{y}$ складному об'єкті та зведення їх у єдину теоретичну картину; на подання складного об'єкта у вигляді ієрархічної системи взаємопов'язаних моделей, що дає змогу формалізувати властивості об'єкта в цілому, його структуру та динаміку [4].

Управління підприємством на основі системного підходу передбачає, що керівники мають бачити організацію як сукупність взаємопов'язаних елементів, таких як персонал, матеріали і обладнання, завдання та технології тощо, які орієнтовані на досягнення однієї мети розвитку підприємства за змінюваних умов у зовнішньому середовищі.
Перед тим як розглянути питання інформаційного забезпечення системного аналізу діяльності підприємства, нагадаємо головні аспекти системного підходу, за якого підприємство розглядається як єдина складна відкрита система управління. При цьому виділяють складові, підсистеми підприємства та відстежують зв'язки між ними. Будь-яке, навіть найменше підприємство, $\epsilon$ досить складною системою, утвореною 3 множини елементів, поєднаних різноманітними зв'язками. Частини підприємства переважно також досить складні і можуть розглядатися як окремі системи або як його підсистеми.

Загалом можна виділити такі великі підсистеми підприємства:

- підсистема стратегічного управління;

- виробнича підсистема;

- підсистема управління виробництвом;

- підсистема управління фінансами;

- підсистема реалізації продукції;

- підсистема організації складського зберігання;

- підсистема управління відносинами 3 клієнтами;

- підсистема управління персоналом;

- підсистема управління

бюджетуванням тощо.

Очевидно, що дослідження таких складних об'єктів пов'язане 3 необхідністю опрацювання, узагальнення та аналізу значного обсягу інформації. Виявлена інформація, як правило, неструктурована та потребує формалізації. Для цього необхідно створити єдиний інформаційний простір, що забезпечить керованість бізнес-процесів та інтелектуальну потужність всієї системи управління, і як наслідок, підвищить рівень конкурентоспроможності підприємства. Безумовно, ключовою ланкою рішення такого завдання $є$ комплексна автоматизація бізнесу, яка грунтується на системному підході. Це означає, що підприємство повинно максимально використовувати всі інформаційні потоки і канали, встановивши ï пріоритетність згідно 3 вартістю, оперативністю, доступністю і достовірністю.

Під комплексною автоматизацією бізнесу або системи управління підприємством будемо розуміти процес створення такої інформаційної системи підприємства, яка дає можливість ефективно управляти всіма напрямками діяльності i 
дозволяє підприємству працювати як єдиній складній системі. Зрозуміло, що основна перевага системного підходу при комплексній автоматизації підприємства в тому, що він об'єднав в процесі автоматизації окремі складові системи підсистеми - в єдину систему, якою $\epsilon$ підприємство.

У загальносистемному плані (3 позиції інформатизації процесу управління на об’єкті) методологічні аспекти автоматизації системи управління підприємства мають охоплювати такі питання: автоматизоване формування первинної документації; автоматизоване формування фінансової та статистичної звітності; автоматизоване формування управлінських рішень; автоматизація інформаційно-довідкового обслуговування управлінців; автоматизація передавання економічної інформації 3 одного рівня на інший тощо.

Автоматизація всіх бізнес-процесів підприємства безпосередньо залежить від особливостей системного мислення керівника, що вимагає підвищення обгрунтованості розробки відповідних рішень щодо регулювання процесів, які будуть автоматизуватися. 3 одного боку, інформаційна система підприємства $\epsilon$ організаційним і управлінським рішенням, що грунтується на інформаційних технологіях i для того, щоб мати повне уявлення про інформаційні системи, керівник підприємства повинен розбиратися у всіх загальних організаційних і управлінських аспектах таких систем і знати їх можливості в області вирішення конкретних проблем. Таке знання інформаційних систем, що включає організаційно-управлінські i технічні аспекти, називають інформаційною грамотністю.

Управління підписмством відбувається за допомогою чіткої ієрархічної структури i формальних стандартних процедур. На типовому підприємстві ієрархія співробітників є пірамідною структурою, де і 3 зростанням рівня зростають авторитет співробітника і його відповідальність. Інформаційні технології дозволяють розв'язати проблему достовірності, оперативності та регулярності управлінської інформації, що дозволяє керівникам всіх рівнів приймати більш ефективні рішення.
Оскільки в кожній організації існують відділи та різні організаційні рівні управління, то для управління ними потрібна одна інформаційна система. Але в реальності нема такої інформаційної системи, яка могла б акумулювати в собі всю інформацію, необхідну для функціонування й управління організації в цілому.

Для роботи на різних організаційних рівнях управління підприємством виділяють, як мінімум, чотири види інформаційних систем: системи операційного рівня; системи для професійної роботи $з$ даними (знаннями); управлінські системи; стратегічні системи (системи стратегічного планування).

Якщо аналізувати особливості автоматизації українських підприємств, то більшість підприємств автоматизовують тільки облікові задачі, що на перших порах задовольняють систему управління українських підприємств. Неефективність інформаційної підтримки управління підприємством обумовлена наявністю «клаптевої» автоматизації діяльності окремих підсистем або структурних елементів. Використання локального підходу до проблеми автоматизації не дозволяє в комплексі розглянути усі процеси, що протікають на підприємстві, та проаналізувати їх 3 позицій системного аналізу.

Керівники підприємств при початковому виборі інформаційних систем повинні кількісно оцінювати різні інформаційні системи за допомогою економіко-математичних моделей i порівнювати їх між собою та 3 «еталонною» моделлю інформаційної системи. Звичайно, такого аналізу ніхто не проводить, що і тягне за собою ряд невдалих спроб упровадження інформаційних систем.

Дослідження питання впровадження інформаційних систем на підприємствах дозволяє виділити такі основні проблеми: неуважність керівництва до проекту впровадження інформаційних систем (приблизно 35-40\%); відсутність чітких цілей проекту впровадження інформаційних систем i недотримання основних принципів системного підходу у автоматизації (1517\%); невмілість керівництва формалізувати бізнес-процеси на підприємстві (10-14\%); неготовність підприємства до змін (10-12\%); 
Вінничук О. Ю.

низька інформаційна грамотність кадрів на підприємстві (3-7\%) тощо.

Отже, сутність системного підходу в автоматизації системи управління підприємства полягає тому що:

- формалізація цілей автоматизації i встановлення їх ієрархії до початку якої-небудь діяльності, яка пов'язана 3 автоматизацією;

- структурний аналіз системи (підприємства), який розкриває характер взаємозв' язків і призначення кожної підсистеми;

- дослідження особливостей управління кожної підсистеми підприємства і механізму зворотних зв'язків для найкращої реалізації планів управління підприємства в цілому;

- вивчення процесів прийняття рішень у кожному блоці системи 3 урахуванням його взаємодії з іншими підсистемами і його місця в системі в цілому;

- отримання максимального ефекту 3 точки зору досягнення цілей шляхом порівняльного аналізу альтернативних варіантів і методів досягнення цілей і здійснення вибору;

- кількісна оцінка цілей i засобів їх досягнення, яка полягає $\mathrm{y}$ всесторонній оцінці всіх можливих i планованих результатів автоматизації.

Отже, використання системного підходу в автоматизації системи управління дасть змогу підвищити керованість підприємством на всіх рівнях, усунути дублювання інформації у роботі органів управління, створити чітку систему управління підприємством.

Викладені результати не охоплюють усього спектра питань, що окреслюють проблемне коло предметної сфери дослідження автоматизації системи управління підприємства на основі системного підходу. Тому надалі доцільно розвинути методичні та дослідити прикладні аспекти процесного управління та проектної методології, моделювання бізнес-процесів тощо.

\section{Список літератури}

1. Кустовська О. В. Методологія системного підходу та наукових досліджень: Курс лекцій / О.В. Кустовська. - Тернопіль : Економічна думка, 2005. - 124 с.

2. Григорків В.С. Економічна кібернетика: Навчальний посібник / В.С. Григорків. Чернівці : Рута, 2006. - 198 с.

3. Катренко А.В. Системний аналіз об’єктів та процесів комп'ютеризації : Навчальний посібник / А.В. Катренко. Львів : Новий світ, 2000. -424 с.

4. Шарапов О. Д. Системний аналіз: Навч.метод. посібник для самост. вивч. дисц. / О.Д. Шарапов, В.Д. Дербенцев, Д.Є. Семьонов. - К. : КНЕУ, 2003. - 154 с.

5. О'Коннор Дж. Искусство системного мышления: Необходимое знание о системах $\mathrm{T}$ творческом подходу $\mathrm{K}$ решению проблем / Дж. О'Коннор, Иан Макдермат. - М. Альпина Бизнес Букс, 2006. $-256 \mathrm{c}$.

6. Анфилатов В.С. Системный анализ в управлении: Учеб. пособие / В.С. Анфилатов, А.А. Емельянов, А.А. Кукушкин; Под ред. А.А. Емельянова. М. : Финансы и статистика, 2002. -368 с.

7. Холод Б.І. Системний підхід - основа сучасного управління діяльністю промислових підприємств / Б.І. Холод, О.М. Зборовська // [Електронний ресурс]. - Режим доступу: http://www.nbuv.gov.ua/portal/Soc_Gum/ao /2010_1/9.pdf.

8. Боклан Н.С. Підвищення керованості організації на основі системного підходу /Н.С. Боклан // [Електронний ресурс]. Режим доступу: http://www. confcontact. com/dec/Boklan.htm. 


\section{Аннотация \\ Елена Винничук \\ СИСТЕМНЫЙ ПОДХОД В АВТОМАТИЗАЦИИ СИСТЕМЫ УПРАВЛЕНИЯ ПРЕДПРИЯТИЕМ}

Статья посвящена выявлению особенностей $u$ преимущееств использования системного подхода как такового, что обеспечит базис для эффективного управления за счет автоматизации системы управления предприятий. Исследованы особенности системного подхода, охарактеризованы преимущества использования системного подхода в анализе и обработке информации на основе комплексной автоматизачии предприятия, определень препятствия, возникающие на пути внедрения системного управления автоматизацией предприятия.

Ключевые слова: системный подход, принциипы системного подхода, системный подход в управлении предприятием; системный подход в автоматизации системы управления предприятием.

\section{Summary}

Olena Vinnychuk

\section{SYSTEMS APPROACH TO AUTOMATION OF ENTERPRISE MANAGEMENT SYSTEM}

Article is devoted to finding features and advantages of the system approach as the one that will provide the basis for effective management through automation companies management. The features of systematic approach investigated, the advantages of using a systematic approach to analyzing and processing information through a comprehensive factory automation described, obstacles encountered in implementing the system management automation company defined.

Keywords: systems approach, principles of system approach, system approach in enterprise management, systems approach to automation of enterprise management system. 
УДК 330.4

(C) Щелкалин В. Н., 2011

Харьковский национальный университет радиоэлектроники, г. Харьков

\title{
МЕТОД “ГУСЕНИЦА"-SSА - АРПСС - СПОАРУГ И МОДЕЛЬ АРСПСС - СПОАРУГ ДЛЯ АНАЛИЗА И ПРОГНОЗИРОВАНИЯ ФИНАНСОВО- ЭКОНОМИЧЕСКИХ ВРЕМЕННЫХ РЯДОВ
}

\begin{abstract}
Проводиться подальший розвиток методу Бокса-Дженкінса побудови моделей $i$ вдосконалення моделей авторегресії - проінтегрованого ковзного середнього (АРПСС), які були розроблені і успішно використовуються близько сорока років у різних галузях науки $i$ техніки $i$ залишаються донині однією з найбільш ефективних моделей для моделювання і прогнозування фінансово-економічних часовіх рядів, перевершуючи своїх конкурентів по иілому ряду критеріїв, таких як: економність за кількістю параметрів, трудомісткість алгоритмів побудови моделей та ресурсомісткість їх реалізаиії, формалізаиією $i$ автоматизацією їхньої побудови. Запропоновано чергову модифікацію моделей ARIMA i GARCH.

Ключові слова: моделювання, фільтрачія, прогнозування, управління, модель АРІКС, метод «Гусениия»-SSA - АРІКС - СПУАРУГ, модель АРСІКС, модель АРСІКС - СПУАРУГ,
\end{abstract} гетероскедастичність, метод Левенберга-Марквардта.

Постановка проблемы. Научнотехнический прогресс постоянно развивает технические, социальные, медицинские в том числе и экономические и прочие системы, усложняя их структуру и увеличивая количество их сложных внутренних взаимосвязей и внешних факторов, от которых они зависят и большинство из которых учесть невозможно. Развитие финансовых рынков сопровождается значительным ростом вовлечённых объёмов капитала, увеличением количества участников рынка. Одним из важных направлений исследований является моделирование динамики доходности и волатильности финансовых рынков. Поэтому актуальной является разработка и использование универсальных математических моделей и методик, позволяющих моделировать, прогнозировать и управлять широким классом процессов, т.к. это позволит повысить эффективность управления и планирования режимов работы сложных экономических систем, сэкономить значительные средства и ресурсы путем всяких математических ухищрений, а также существенно разгружает работу персонала различных организаций, позволяет предвидеть рисковые ситуации и привносит еще много прочей пользы.
Главными требованиями к построению математических моделей в $70-$ 90-е годы прошлого века, являлись экономность по количеству параметров, скорость определения модели и её ресурсоёмкость для использования на доступных тогда ЭВМ малой производительности. Однако, современная вычислительная техника и методы математического моделирования предоставляют большие возможности для анализа, моделирования и прогнозирования временных рядов различной природы. Поэтому в настоящее время указанные требования не являются определяющими и современные вычислительные средства и системы позволяют выносить на первый план требования точности моделирования, качества анализа и прогнозирования.

Анализ последних исследований и публикаций. В 70-е годы прошлого века одним из полезных инструментов анализа и прогнозирования финансово-экономических временных рядов считались модели ARIMA и метод Бокса-Дженкинса их построения [1].

Метод сезонной ARMA работает только с предварительно приведенными к стационарному виду временными рядами. Нестационарный ряд обычно характеризуется присутствием большой 
мощности на низких частотах. Важной является задача элиминирования трендовой составляющей временного ряда. В таких случаях всё, что делалось, - это отфильтровывались нестационарные низкочастотные компоненты и использовался оставшийся ряд для дальнейшего анализа. При этом в качестве фильтра для устранения низкочастотных компонент в моделях ARIMA использовался фильтр первых разностей, максимум вторых. А поэтому метод сезонной ARIMA удовлетворительно моделировал и прогнозировал временные ряды только относительно простой структуры.

В 80-е же годы прошлого века Гренджер и Джойо [2] предложили новый класс ARFIMA моделей, удобно описывающего финансово-экономические временные ряды с эффектами длинной и короткой памяти. 2000-е годы характеризуются применением большого спектра моделей для анализа и прогнозирования финансово-экономических временных рядов, а также ансамблей моделей с различной структурой. С появлением высокоскоростных ЭВМ происходил и переход от ансамблей прогнозирующих моделей к ихним комбинациям. Отличие комбинированных моделей от их ансамблей заключается в одновременном подстраивании параметров моделей.

Наиболее важными характеристиками моделей при анализе и выборе наиболее подходящих математических моделей в экономике являются следующие характеристики:

- способ моделирования трендовой составляющей временного ряда;

- способ нелинейного моделирования временного ряда;

- способ моделирования случайной составляющей временного ряда;

- способ учёта влияния внешних факторов на процесс.

Поэтому приоритетным видом моделей являются комбинированные вероятностнодетерминированные прогнозные модели с нелинейным усложнением, т.к. при этом в модели одновременно учитываются и используются как статистические, так и детерминированные составляющие, что позволяет достичь наилучшего качества прогнозирования [3]. Среди детерминированных моделей приоритетным вариантом является детерминированная модель спектрального разложения, реализующая моделирование на основе разложения по детерминированному ортонормированному базису, отличному от гармонических функций. В то время как наиболее приоритетной среди вероятностных моделей является модель авторегрессии проинтегрированного скользящего среднего.

Формулирование целей статьи. В зарубежной литературе давно известны комбинированные вероятностнодетерминированные модели, представленные в [3]. В данной же статье предлагается очередная модификация моделей ARIMA и GARCH, впервые предложены метод "Гусеница"-SSA - АРПСС - СПОАРУГ, комбинированная вероятностнодетерминированная модель авторегрессии спектрально проинтегрированного скользящего среднего со спектрально проинтегрированной обобщённой авторегрессионной гетероскедастичностью (АРСПСС СПОАРУГ, на англ. яз. ARSIMA SIGARCH, на укр. яз. АРСІКС - СIУАРУГ) и метод её построения, которые позволяют более гибко анализировать, моделировать и прогнозировать финансово-экономические временные ряды в сравнении с моделями ARIMA - GARCH.

Изложение основного материала исследования. Суть метода сначала заключалась в многомерной декомпозиции экзогенных временных рядов и прогнозируемого временного ряда, на базисные латентные компоненты, включая их степени и комбинации, получаемые методами главных (PCA), гладких (SCA) и независимых компонентов (ICA) в отборе из этих базисных компонентов конструктивных методом быстрого ортогонального поиска (FOS), одного из самых эффективных и экономных по временными затратами методов в зарубежной литературе, и отсечении деструктивных, тем самым сформировав передаточную функцию математической модели процесса; в дальнейшей идентификации шумовой части 
математической модели процесса благодаря сезонным моделям авторегрессии скользящего среднего, и одновременной параметрической идентификации полученной структуры модели методом Левенберга-Марквардта [4]. Как стало известно позже, пердлоденный метод схож с декомпозиционным методом моделирования (ДММ) [3]. Метод "Гусеница"-SSA тоже использует декомпозицию временных рядов по сингулярным значениям (SVD). Известны публикации использования метода “Гусеница"-SSA в различных отраслях науки и техники как метода достаточно хорошо описывающего нестационарные временные ряды с линейными, параболическими или экспоненциальными трендами с не всегда устойчивой колебательной составляющей, однако метод для моделирования использует неоптимальный с точки зрения точности воспроизведения некоторых временных рядов ортогональный базис векторов траекторной матрицы. Поэтому было предложено совместно использовать рекуррентную модель прогнозирования метода "Гусеница"-SSA и модель авторегрессии - скользящего среднего, обученных на конкурентной основе с учётом обобщённого критерия точности и адекватности. Использование такой комбинации было продиктовано тем, что отдельно эти подходы имеют ряд недостатков, а совместное их использование приводит к синергии, повышая их эффективность, робастность и адекватность. Однако при выделении тренда методом “Гусеница"-SSA, как и любым другим методом, остаточная составляющая ряда в большинстве случаев остаётся нестационарной, поэтому далее метод “Гусеница"-SSA использовался уже в комбинации с моделью авторегрессии проинтегрированного скользящего среднего (АРПСС). При этом совместное использование приведенных выше методов подразумевает, что параметрическая идентификация осуществляет вычисление оценок параметров модели АРПСС и нелинейного обобщения авторегрессии на главных компонентах, минимизируя сумму квадратов отклонений ошибок моделирования с учетом временного ряда, получаемого методом “Гусеница"-SSA, который в течение моделирования не имеет модели и соответственно параметров, а метод Левенберга-Марквардта, вычисляя параметры остальных аддитивных частей модели помогает определить внешний вид временного ряда метода “Гусеница"-SSA, выступающего в роли помощника определения детерминированной (трендовой) составляющей процесса.

Предлагаемый подход как раз и является одним из вариантов приоритетных на сегодняшний день комбинированных вероятностно-детерминированных подходов. Здесь также реализуется так называемый трендовый подход, когда процесс моделируется как отклонение фактических значений от тренда (который представлен здесь временным рядом, получаемым методом “Гусеница"-SSA) и который обеспечивает устойчивость получаемой модели и достаточную точность моделирования, тогда как ранее вероятностной моделью АРПСС пытались описать весь процесс. Таким образом, произведена успешная попытка спустя более тридцати лет после создания метода БоксаДженкинса и метода “Гусеница"-SSA объединить их. Однако для удовлетворения таких требований к моделям, как: скорость обучения, трудоёмкость, ресурсоёмкость, наглядность модели, простота использования и интерпретируемость, затратный по времени и ресурсам метод "Гусеница"-SSA в дальнейшем было предложено использовать лишь для предварительной структурной идентификации и грубой параметрической идентификации так называемого интегрирующего полинома от оператора задержки предлагаемой модели, а также для грубой структурной и параметрической идентификации полинома от оператора задержки, наличие которого отличает более общую полиномиальную модель от модели Бокса-Дженкинса, структура и коэффициенты которого сначала равны таковыми рекуррентной модели прогнозирования метода “Гусеница"-SSA.

\begin{tabular}{lrr}
\multicolumn{1}{c}{ Метод } & “Гусеница”-SSA & также \\
предлагается & использовать & для \\
предварительного & обобщённого
\end{tabular}
коинтегрирования временных рядов при моделировании многосвязных процессов, а также для разделения отдельно на финитный 
и отдельно на апериодический регуляторы в случае использования предлагаемой модели в теории автоматического управления [5]. Также возможно нелинейное усложнение передаточной функции модели одним из способов: FOS, GMDH, RBF, LARS, построенных на главных компонентах, их степенях и сочетаниях. Поэтому, в первую очередь, предлагаемая автором модель направлена на теорию автоматического управления, моделирование и прогнозирование технических систем и технологических процессов, в связи с тем, что их передаточные функции более детерминированные и имеют сложную нелинейную структуру.

Описание предлагаемых

математических моделей. Математическая модель процессов, зависящих от нескольких экзогенных факторов в операторной форме может быть представлена в виде модели сезонной авторегрессии

проинтегрированного скользящего среднего (САРПССЭ) [6]:

$$
z_{t}^{y}=\sum_{i=1}^{N} \frac{b_{n_{b^{i}}}^{i}(L)}{a_{n_{a^{i}}}^{i}(L)} \cdot z_{t-m_{i}}^{x^{i}}+\frac{c_{n_{c}^{\Sigma}}^{\Pi}(L)}{d_{n_{d}^{\nabla}}^{\nabla}(L)} \cdot e_{t}
$$

где $L-$ оператор сдвига по времени на одну единицу назад, такой что $L^{i} x_{t}=x_{t-i}$,
$N$ - количество экзогенных переменных; $z_{t}^{y}$ - пронормированный от 0 до 1 по формуле $z_{t}^{y}=\frac{y_{t}-y_{t}^{\min }}{y_{t}^{\max }-y_{t}^{\min }}$ или каким-либо другим способом временной ряд $y_{t}$ моделируемого и прогнозируемого процесса с вычтенным средним значением; $z_{t-m_{i}}^{x^{i}}-$ пронормированный таким же образом $i$-й экзогенный временной ряд $x_{t}^{i}$ с вычтенным средним значением; $m_{i}$ - задержка $i$-го экзогенного временного ряда $x_{t}^{i}$ по времени относительно прогнозируемого временного ряда $y_{t} ; a_{a_{a^{i}}}^{i}(L), b_{n_{b^{i}}}^{i}(L)$ - полиномы от $L$ степеней $n_{a^{i}}$ и $n_{b^{i}} \quad$ соответственно; $c_{n_{c}^{\Sigma}}^{\Pi}(L)=c_{n_{c}^{1}}^{1}\left(L^{s_{1}}\right) \cdot c_{n_{c}^{2}}^{2}\left(L^{s_{2}}\right) \times \ldots \times c_{n_{c}^{n_{s}}}^{n_{s}}\left(L^{s_{n_{s}}}\right)=\prod_{i=1}^{n_{s}} c_{n_{c}^{i}}^{i}\left(L^{s_{i}}\right)$ - полином $L^{s_{i}}$ степени $n_{c}^{i}$, определяющий составляющую скользящего среднего периодической компоненты с периодом $s_{i}$, $n_{c}^{\Sigma}=\sum_{i=1}^{n_{s}} n_{c}^{i} \cdot s_{i}$
$d_{n_{d}^{\nabla}}^{\nabla}(L)=d_{n_{d}^{\Sigma}}^{\Pi}(L) \nabla_{s_{1}}^{D_{1}} \nabla_{s_{2}}^{D_{2}} \ldots \nabla_{s_{n_{s}}}^{D_{n_{s}}}=d_{n_{d}^{1}}^{1}\left(L^{S_{1}}\right) \cdot d_{n_{d}^{2}}^{2}\left(L^{S_{2}}\right) \cdot \ldots \cdot d_{n_{d}^{n_{s}}}^{n_{s}}\left(L^{S_{n_{s}}}\right) \nabla_{s_{1}}^{D_{1}} \nabla_{s_{2}}^{D_{2}} \ldots \nabla_{s_{n_{s}}}^{D_{n_{s}}}=$ $=\prod_{i=1}^{n_{s}} d_{n_{d}^{i}}^{i}\left(L^{s_{i}}\right) \nabla_{s_{1}}^{D_{1}} \nabla_{s_{2}}^{D_{2}} \ldots \nabla_{s_{n_{s}}}^{D_{n_{s}}}$

$n_{d}^{\nabla}=n_{d}^{\Sigma}+\sum_{i=1}^{n} D_{i} \cdot s_{i}$

$d_{n_{d}^{\Sigma}}^{\Pi}(L)=d_{n_{d}^{1}}^{1}\left(L^{S_{1}}\right) \cdot d_{n_{d}^{2}}^{2}\left(L^{S_{2}}\right) \times \ldots \times d_{n_{d}^{n_{s}}}^{n_{n_{s}}}\left(L^{S_{n_{s}}}\right)=$ $=\prod_{i=1}^{n_{s}} d_{n_{d}^{i}}^{i}\left(L^{S_{i}}\right)-$ полином от $L^{S_{i}}$ степени $n_{d}^{i}$, определяющий составляющую авторегрессии сезонной компоненты с периодом $s_{i}$, $n_{d}^{\Sigma}=\sum_{i=1}^{n_{s}} n_{d}^{i} \cdot s_{i} ; \quad e_{t}-$ остаточные ошибки модели: $D_{i}-$ порядок взятия разности $s_{i}$; $\nabla_{s_{i}}$ и $L^{s_{i}}-$ упрощающие операторы такие, что $\nabla_{s_{i}} y_{t}=\left(1-L^{s_{i}}\right) \cdot y_{t}=y_{t}-y_{t-s_{i}}$.

Выражение (1) в более компактной форме можно представить в виде:

$$
\begin{aligned}
& \quad \widetilde{a}(q) \cdot z_{t}^{y}=\sum_{i=1}^{k} \widetilde{b}^{i}(q) \cdot z_{t-m_{i}}^{x^{i}}+\widetilde{c}(q) \cdot e_{t}, \\
& \text { где } \widetilde{a}(L)=d_{n_{d}^{\nabla}}^{\nabla}(L) \cdot \prod_{i=1}^{N} a_{n_{a^{i}}}^{i}(L), \\
& \widetilde{b}^{i}(L)=b_{n_{b^{i}}}^{i}(L) \cdot d_{n_{d}^{\nabla}}^{\nabla}(L) \cdot \prod_{j=1, i \neq j}^{N} a_{n_{a^{j}}}^{j}(L), \\
& \widetilde{c}(q)=c_{n_{c}^{\Sigma}}^{\Pi}(q) \cdot \prod_{i=1}^{N} a_{n_{a^{i}}}^{i}(q), i=\overline{1, N} .
\end{aligned}
$$

Выражение для прогноза с упреждением $l$ при помощи предложенной модели совместного использования модели 
метода "Гусеница"-SSA и сезонной модели авторегрессии - проинтегрированного скользящего среднего с экзогенными переменными, после приведения еe от дробно-разностного (рационального) к разностному уравнению принимает вид:

$$
\begin{aligned}
& \hat{y}_{t}(l)=\hat{y}_{t}^{S S A}(l)+\sum_{j=1}^{n_{d}^{\Sigma}+\sum_{i=1}^{N} n_{a^{i}}} \widetilde{a}_{j} \cdot h_{t+l-j}^{y}+ \\
& +\sum_{i=1}^{N}\left(\widetilde{b}_{0}^{i} \cdot x_{t+l-m_{i}}^{i}-\sum_{j=1}^{n_{d}^{\Sigma}+n_{b^{i}}+\sum_{p=1}^{N} n_{a^{p}}} \widetilde{b}_{j}^{i} \cdot x_{t+l-m_{i}-j}^{i}\right)-\sum_{j=1}^{n_{c}^{\Sigma}+\sum_{i=1}^{N} n_{a^{i}}} \widetilde{c}_{j} \cdot e_{t+l-j} ; \\
& \hat{x}_{t}^{i}(l)=\hat{x}^{k}{ }_{t}^{S S A}(l)+\sum_{j=1}^{n^{k^{\Sigma}}} \widetilde{a}_{x^{k} j} \cdot z_{t+l-j}^{x^{k}}+\sum_{j=1}^{n^{k^{\Sigma}} c} \widetilde{c}_{x^{k}} \cdot e_{x^{k}}{ }_{t+l-j}, k=\overline{1, N},
\end{aligned}
$$

$$
\text { где } a_{a_{a^{i}}}^{i}(L), \quad b_{n_{b^{i}}}^{i}(L) \text { - полиномы от } L
$$$$
\text { степеней } n_{a^{i}} \text { и } n_{b^{i}} \quad \text { соответственно; }
$$$$
y_{t+j}=\left\{\begin{array}{l}
y_{t+j}, j \leq 0, \\
\hat{y}_{t}(j), j>0,
\end{array} \quad x_{t+j}^{i}=\left\{\begin{array}{l}
x_{t+j}^{i}, j \leq 0, \\
\hat{x}_{t}^{i}(j), j>0,
\end{array}\right.\right.
$$$$
X=\left(\begin{array}{lllll}
X_{1} & X_{2} & \ldots & X_{N} & Y
\end{array}\right)=\left(\begin{array}{ll}
X_{1,1} &
\end{array}\right.
$$$$
\left.\begin{array}{lllllllllll}
\ldots & X_{2, K} & \ldots & X_{N, 1} & X_{N, 2} & \ldots & X_{N, K} & Y_{1} & Y_{2} & \ldots & Y_{K}
\end{array}\right)
$$$$
\text { ; } \quad Y_{j}=\left(\begin{array}{llll}
y_{j-1} & y_{j-2} & \ldots & y_{j+L-2}
\end{array}\right)^{T},
$$$$
X_{i, j}=\left(\begin{array}{llll}
x_{j-1}^{i} & x_{j-2}^{i} & \ldots & x_{j+L-2}^{i}
\end{array}\right), \quad i=\overline{1, N},
$$$$
j=\overline{1, K}-\text { преобразования исходного }
$$
$(N+1)$-мерного временного ряда $(N-$ количество экзогенных временных рядов и один прогнозируемый) в последовательность $L^{y}$ - мерных векторов ( $L^{y}$ - ширина окна), число которых равно $(N+1) \cdot K$, $K=n-L^{y}+1$, где $n$ - длина временных рядов; $u_{L}^{i}$ - последний элемент вектора $U^{i}$; $R$ - количество элементов сингулярного разложения; $\quad \hat{y}_{t}^{S S A}(i)=\sum_{j=1}^{L-1} f_{j}^{y} \cdot \widetilde{w}^{y_{t+i-j}^{N+1}} \quad-$ модель рекуррентного прогнозирования метода "Гусеница"-SSA временного ряда $y_{t}$, $t=\overline{0, n-1}$; которая в свою очередь нередко может быть экономно записана сезонной моделью АРПСС (АРП) или при помощи модели распределенных лагов Алмон, где $\tilde{w}_{0}^{y^{N+1}}, \quad \tilde{w}_{1}^{y_{1}^{N+1}}, \quad \ldots, \quad \widetilde{w}_{n-1}^{y^{N+1}}-$ ряд соответствующий преобразованию

$$
\begin{aligned}
& i=\overline{1, N} \text {; } \\
& e_{t+j}=\left\{\begin{array}{l}
e_{t+j}, j \leq 0, \\
0, j>0 .
\end{array} ;\right. \\
& h_{i}^{y}=y_{i}-\widetilde{w}_{i}^{N+1} ; \quad \hat{y}_{t}^{S S A}(i)=\sum_{j=1}^{L-1} f_{j}^{y} \cdot \widetilde{w}_{t+i-j}^{y^{N+1}}, \\
& i=\overline{1, l} ; \quad \widetilde{w}_{i}^{y^{N+1}}=\left\{\begin{array}{l}
\hat{y}_{i}, i>t, \\
\widetilde{w}_{i}^{y_{i}^{N+1}, i \leq t ;}
\end{array}\right. \\
& \left(f_{L-1}^{y}, f_{L-2}^{y}, \ldots, f_{1}^{y}\right)^{T}=\frac{1}{1-\sum_{i=1}^{R}\left(u_{L}^{i}\right)^{2}} \sum_{i=1}^{R} u_{L}^{i} \cdot\left(\begin{array}{llll}
u_{1}^{i} & u_{2}^{i} & \ldots & u_{L-1}^{i}
\end{array}\right)^{T}
\end{aligned}
$$$$
\text { , где }\left(\begin{array}{llll}
u_{1}^{i} & u_{2}^{i} & \ldots & u_{L-1}^{i}
\end{array}\right)^{T} \quad-\text { вектор, }
$$
состоящий из первых $(L-1)$ элементов $i$ того собственного вектора $U^{i}$ сингулярного разложения траекторной матрицы экзогенных и моделируемого процессов
$\begin{array}{llllll}X_{1,2} & \ldots & X_{1, K} & X_{2,1} & X_{2,2} & \ldots\end{array}$

прогнозируемого временного ряда $y_{t}$; ряды $\widetilde{w}^{x^{i}}, \widetilde{w}^{x^{i}}, \ldots, \widetilde{w}^{x^{i}}{ }_{n-1}, i=\overline{1, N}$ соответствуют преобразованиям $i$-ых временных рядов, соответствующих экзогенным временным рядам, при помощи сингулярного спектрального анализа на этапе диагонального усреднения, переводящего матрицу $\widetilde{Z}^{i}, \quad i=\overline{1, N+1}$ состоящую из $K$ столбцов от $(i-1) \cdot K$-го до $i \cdot K-1$-го матрицы $Z$ в ряды $\widetilde{w}^{x^{i}}, \widetilde{w}^{x^{i}}, \ldots, \widetilde{w}^{x^{i}-1}$, по формуле

$$
\widetilde{w}^{y^{k}}=\left\{\begin{array}{l}
\frac{1}{i+1} \sum_{j=1}^{k+1} \widetilde{z}_{j, i-j+2}^{i}, i=\overline{0, \min (L, K)-2} ; \\
\frac{1}{\min (L, K)} \sum_{j=1}^{\min (L, K)} \widetilde{z}_{j, i-j+2}^{i}, i=\overline{\min (L, K)-1, \max (L, K)-1} ; \\
\frac{1}{n-i} \sum_{j=k-\max (L, K)+2} \sum_{j, i-j+2}^{i}, i=\overline{\max (L, K), n-1},
\end{array}\right.
$$

$k=\overline{1, N+1}$; где $Z=\widetilde{Z}^{i}+\ldots+\widetilde{Z}^{j}-$ сумма $\widetilde{Z}^{i}=\left(U^{i} \cdot\left(U^{i}\right)^{T} \cdot X_{1} \quad U^{i} \cdot\left(U^{i}\right)^{T} \cdot X_{2} \quad \ldots \quad U^{i} \cdot\left(U^{i}\right)^{T} \cdot X_{N} U^{i} \cdot\left(U^{i}\right)^{T} \cdot Y\right)$ матриц разложения, отобранных стандартным анализом собственных чисел траекторной матрицы в методе "Гусеница"SSA. Имеется и модификация рекуррентного метода SSA-прогнозирования - векторное 
SSA-прогнозирование [7], которое в ряде случаев позволяет получать более точные

прогнозы. $\quad \hat{x}_{t}{ }_{t}^{S S A}(i)=\sum_{j=1}^{L^{y}-1} f_{j}^{x^{k}} \cdot \widetilde{w}^{x^{k}{ }_{t+i-j}+1}$,

$k=\overline{1, N}$, тоже самое, только для $k$-того $i=\overline{1, N}$ аналогично интерпретируются как для временного ряда $y_{t}, t=\overline{1, n}$;

C нелинейным усложнением передаточной функции первое уравнение в (2) принимает вид:

экзогенного временного ряда, а также все переменные и параметры с индексом $x^{i}$,

$$
\begin{aligned}
& \hat{z}_{t}^{y}(l)=\hat{y}_{t}^{S S A}(l)+\sum_{i=1}^{r} g_{i} \cdot p_{t}^{i}+\sum_{j=1}^{n_{d}^{\Sigma}+\sum_{i=1}^{N} n_{a^{i}}} \widetilde{a}_{j} \cdot h_{t+l-j}^{y}+ \\
& +\sum_{i=1}^{N}\left(\widetilde{b}_{0}^{i} \cdot z_{t+l-m_{i}}^{x^{i}}-\sum_{j=1}^{n_{d}^{\Sigma}+n_{b^{i}}+\sum_{p=1}^{N} n_{a^{p}}} \widetilde{b}_{j}^{i} \cdot z_{t+l-m_{i}-j}^{x^{i}}\right)-\sum_{j=1}^{n_{c}^{\Sigma}+\sum_{i=1}^{N} n_{a^{i}}} \widetilde{c}_{j} \cdot e_{t+l-j},
\end{aligned}
$$$$
\hat{x}_{t}^{i}(l)=\hat{x}_{t}^{k S S A}(l)+\sum_{j=1}^{n^{k^{k^{\Sigma}}} d} \widetilde{a}_{x^{k} j} \cdot z_{t+l-j}^{x^{k}}+\sum_{j=1}^{n^{k^{k^{\Sigma}}}} \widetilde{c}_{x^{k} j} \cdot e_{x^{k}}{ }_{t+l-j}, k=\overline{1, N}
$$

где $g_{i} \cdot p_{t}^{i}-$ члены полинома КолмогороваГабора:

$$
\begin{array}{r}
\sum_{i=1}^{r} g_{i} \cdot p_{i}^{t}=\operatorname{FOS}\left(\sum_{i=1}^{M} \widetilde{g}_{i} \cdot \tilde{x}_{t}^{i}+\sum_{i=1}^{M} \sum_{j=1}^{M} \tilde{g}_{i j} \cdot \tilde{x}_{t}^{i} \cdot \tilde{x}_{t}^{j}+\sum_{i=1}^{M} \sum_{j=1}^{M} \sum_{k=1}^{M} \tilde{g}_{i j k} \cdot \tilde{x}_{t}^{i} \cdot \tilde{x}_{t}^{j} \cdot \tilde{x}_{t}^{k}+\ldots\right) \\
g_{n}=\tilde{g}_{i j \ldots k}, n=\overline{1, r} \quad \text { или } \quad \text { помощи алгоритма быстрого ортогон бо }
\end{array}
$$$$
\sum_{i=1}^{r} g_{i} \cdot p_{i}^{t}=\operatorname{FOS}\left(\sum_{i=1}^{M_{2}} \widetilde{g}_{i} \cdot \varphi_{i}\left(\overline{\widetilde{x}}_{t}\right)\right), \quad \text { где }
$$$$
\varphi_{i}\left(\overline{\widetilde{x}}_{t}\right)=\frac{1}{(2 \pi)^{-\frac{M}{2}} \cdot\left|\sum_{i}\right|^{-\frac{1}{2}}} \cdot e^{-\frac{1}{2}\left(\overline{\widetilde{x}}_{t}-\bar{c}_{i}\right) \Sigma_{i}^{-1} \cdot\left(\overline{\bar{x}}_{t}-\bar{c}_{i}\right)^{T}}, \bar{c}_{i}-
$$

вектор математических ожиданий временных рядов, представляющих главные компоненты, $\Sigma_{i}$ - ковариационные матрицы, $i=\overline{1, M}$;

или

$$
\sum_{i=1}^{r} g_{i} \cdot p_{i}^{t}=\operatorname{GMDH}\left(\tilde{x}_{t}^{1}, \tilde{x}_{t}^{2}, \ldots, \tilde{x}_{t}^{M}\right)
$$

структурная идентификация методом МГУА, $p_{l}^{t}=\tilde{x}_{t}^{i} \cdot \tilde{x}_{t}^{j} \cdot \ldots \cdot \tilde{x}_{t}^{k}, \quad$ составленного из главных компонент обозначенных $\tilde{x}_{t}^{i}, i=\overline{1, M}, \quad$ а также их степеней и сочетаний, отобранных при помощи FOSалгоритма, определяющего нелинейную часть предложенной модели; $F O S$ функция структурного упрощения модели, записанной в её аргументе, с учетом характера поведения временных рядов, при помощи алгоритма быстрого ортогонального поиска; $h_{i}^{y}=z_{i}^{y}-\widetilde{w}_{i}^{N+1}-\sum_{i=1}^{r} g_{i} \cdot p_{t}^{i}$.

Процесс нахождения таких комбинированных моделей (2) совместного использования модели АРПСС и метода “Гусеница"-SSA может быть продолжительным в связи с ресурсоемкостью метода "Гусеница"-SSA. Поэтому метод "Гусеница"-SSA анализа предложено использовать лишь для предварительной структурной идентификации и грубой параметрической идентификации интегрирующего полинома $w(L)$ (отсюда и название модель авторегрессии спектрально проинтегрированного скользящего среднего) от оператора задержки $L$, который также может быть интерпретирован как оператор перевода в пространство состояний, модели

$$
f(L) \cdot w(L) \cdot y_{t}=\frac{c(L)}{d(L)} \cdot e_{t} \quad-\quad \text { модель }
$$

АРСПСС,

a рекуррентный метод SSA-прогнозирования для грубой структурной и параметрической идентификации полинома $f(L)$, структура и 
коэффициенты которого сначала равны таковыми рекуррентной модели прогнозирования метода “Гусеница"-SSA и наличие которого отличает более общую полиномиальную модель от модели БоксаДженкинса, а также совместно с $w(L)$ определяющих долгосрочную память модели, описывая более широкий класс процессов долгосрочной памяти, чем при фрактальном интегрировании в модели ARFIMA, которая в свою очередь была придумана для преодоления недостатка ARIMA моделей при моделировании и прогнозировании процессов в длинной памятью - потери (искажения) долгосрочной

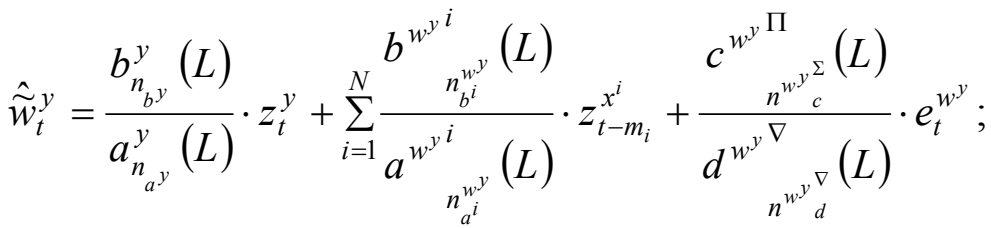

$$
\begin{aligned}
& f^{y}(L) \cdot \hat{\tilde{w}}_{t}^{y}=\sum_{i=1}^{N} \frac{b_{n_{b^{i}}}^{i}(L)}{a_{n_{a^{i}}}^{i}(L)} \cdot z_{t-m_{i}}^{x^{j}}+\frac{c_{n_{c}^{\Sigma}}^{\Pi}(L)}{d_{n_{d}^{\nabla}}^{\nabla}(L)} \cdot e_{t} \\
& f^{x_{i}}(L) \cdot \omega(L) \cdot z_{t}^{x^{j}}=\frac{c^{x^{j}{ }_{n_{x}{ }_{c}}{ }_{c}}(L)}{d^{x^{j}{ }_{n_{x^{j}} \nabla} \nabla}(L)} \cdot e_{t}^{x^{j}}, j=\overline{1, N},
\end{aligned}
$$

$\hat{\widetilde{w}}_{i}^{y}$ - аппроксимация временным рядом $\hat{y}_{t}$ и экзогенными временными рядами $x_{t}^{j}$, $j=\overline{1, N}$ временного ряда $\widetilde{w}_{t}^{y}$ при помощи модели сезонной АРПССЭ или АРПЭ, изначально полученного методом "Гусеница"-SSA, а впоследствии подстраиваемого оптимизационным методом при конкурентном обучении модели; $\omega(L)-$ интегрирующий полином, переводящий временной ряд $x_{t}^{j}$ во временной ряд $\hat{\widetilde{w}}_{t}^{x^{j}}-$ аппроксимация временного ряда $\widetilde{w}_{x^{k}}^{N+1}$ моделью АРПСС; начальные грубые значения коэффициентов полиномов $f^{y}(L)$, $f^{x_{i}}(L)$ и их количество можно брать равными коэффициентам $f_{j}^{y}$ и $f_{j}^{x_{i}}$, $j=\overline{1, N}$ моделей рекуррентного $\mathrm{SSA}-$ информации при взятии приращений. Полиномы $d(L)$ и $c(L)$, в свою очередь, определяют краткосрочные зависимости процесса.

При анализе и прогнозировании финансово-экономических временных рядов, зависящих от нескольких других необходима сбалансированность динамических свойств переменных, стоящих в левой и правой частях уравнения модели. В этом случае идеи метода "Гусеница"-SSA выступают для предварительной обобщённой коинтеграции временных рядов и модель разбивается следующим образом: 


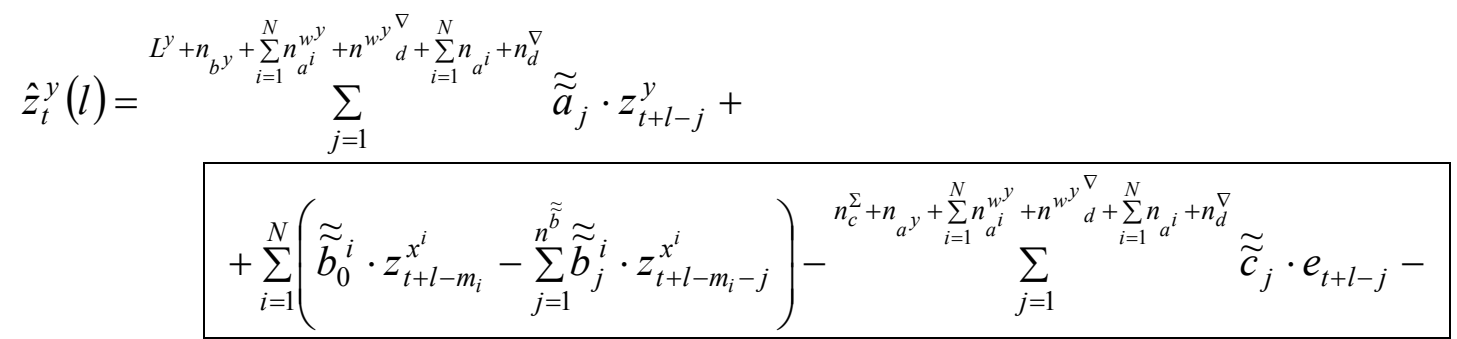

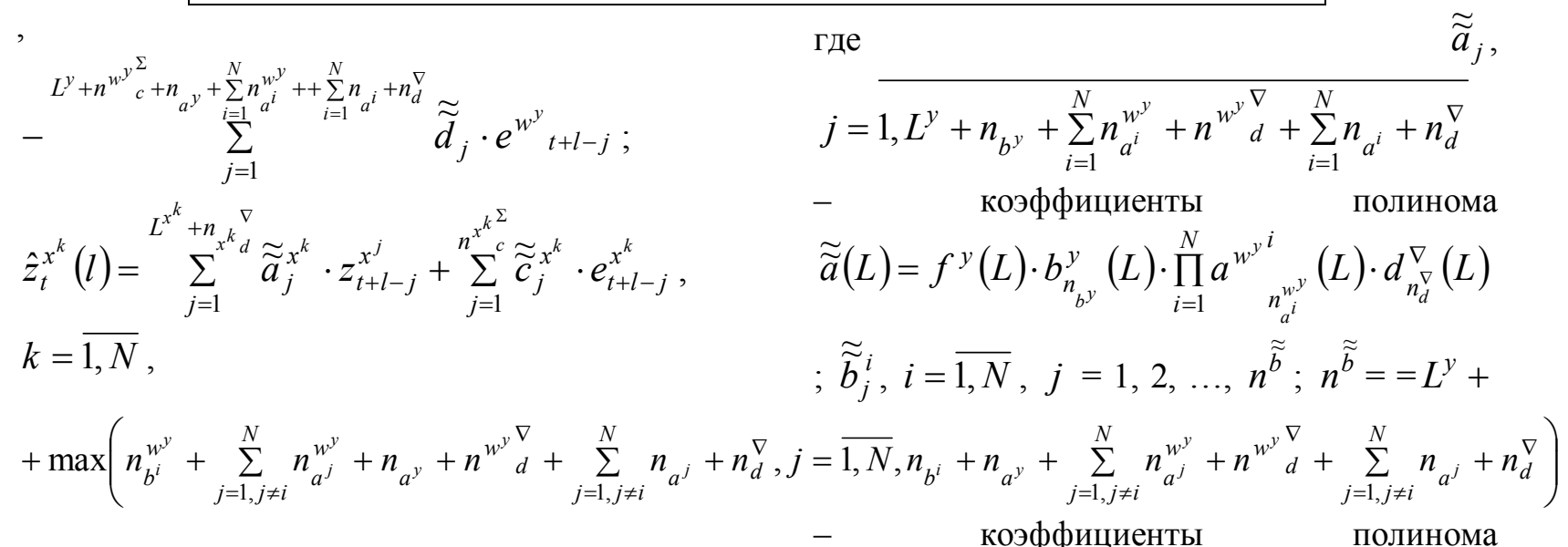

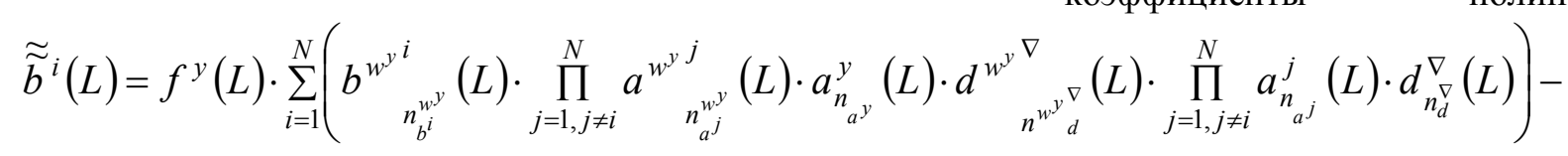

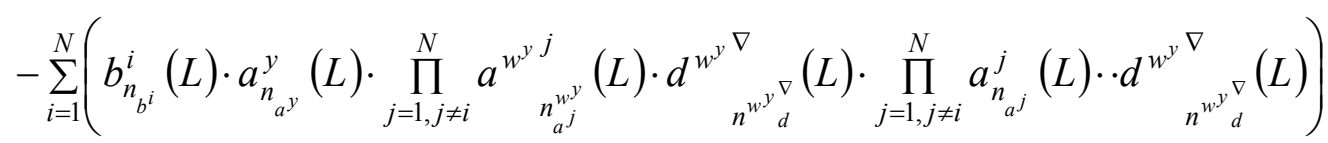$$
\widetilde{\widetilde{c}}_{j}
$$$$
j=\overline{1, n_{c}^{\Sigma}+n_{a^{y}}+\sum_{i=1}^{N} n_{a^{i}}^{w^{y}}+n^{w^{y} \nabla}+\sum_{i=1}^{N} n_{a^{i}}+n_{d}^{\nabla}}
$$

полинома

$$
\begin{aligned}
& \text { коэффициенты } \\
& \widetilde{\widetilde{c}}(L)=c_{n_{c}^{\Sigma}}^{\Pi}(L) \cdot a_{a_{a^{y}}}^{y}(L) \cdot \prod_{i=1}^{N} a_{n_{a^{i}}^{w^{w^{y}}}}(L) \cdot d^{w^{y^{\nu}}} \underset{n^{w^{y^{\nabla}}}{ }_{d}^{\nabla}}{ }(L) \cdot \prod_{i=1}^{N} a_{a_{a^{i}}}^{i}(L) \cdot d_{n_{d}^{\nabla}}^{\nabla}(L)
\end{aligned}
$$

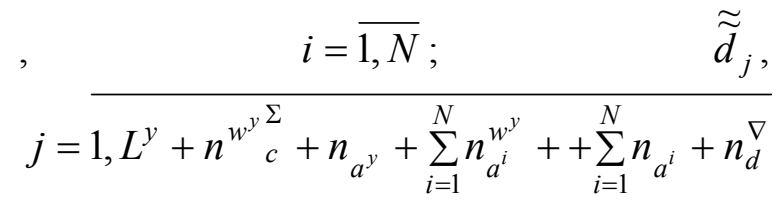

коэффициенты

$$
\text { полинома }
$$

$$
\widetilde{\widetilde{d}}(L)=f^{y}(L) \cdot c^{w^{w^{y}}}{ }_{n^{w^{y^{\Sigma}}}}(L) \cdot a_{a_{a^{y}}}^{y}(L) \cdot \prod_{i=1}^{N} a^{w^{y^{i}}}{ }_{n_{a^{i}}^{w^{y}}}(L) \cdot \prod_{i=1}^{N} a_{a_{a^{i}}}^{i}(L) \cdot d_{n_{d}^{\nabla}}^{\nabla}(L)
$$

,$\quad i=\overline{1, N} ; \quad \widetilde{\widetilde{a}}_{j}^{x^{i}}, \quad j=\overline{1, L^{x^{k}}+L^{\omega}+n^{x^{k} \nabla}}-$

коэффициенты

$$
\widetilde{\widetilde{a}}^{x^{i}}(L)=f^{x^{i}}(L) \cdot \omega(L) \cdot d^{x^{x^{i}}}{ }_{n^{x^{i}}}(L) ; \quad \widetilde{\widetilde{c}}^{x^{i}}{ }_{j},
$$

$j=\overline{1, n^{x^{k^{\Sigma} \Sigma}}} \quad-$ коэффициенты полинома $\widetilde{\widetilde{c}}^{x^{i}}(L)=c^{x^{i^{\Pi}}} n_{n^{x^{i}}}(L)$.

Для учета гетероскедастичности процесса (изменения дисперсии процесса во времени) применяется обобщенная модель с авторегрессионной 
гетероскедастичностью $\operatorname{GARCH}(m, r)$,

имеющая вид [8]:

$\sigma_{t}^{2}=w+\theta(L) \varepsilon_{t}^{2}+\varphi(L) \sigma_{t}^{2}$,

где $\sigma_{t}^{2}-$ временной ряд изменения

дисперсии процесса $y_{t}$,

$\theta(L)=\theta_{1} L+\theta_{2} L^{2}+\ldots+\theta_{p} L^{m}$,

$\varphi(L)=\varphi_{1} L+\varphi_{2} L^{2}+\ldots+\varphi_{r} L^{r}, \quad \varepsilon_{t}^{2} \quad-$

остаточные члены модели. Модель $\operatorname{GARCH}(m, r)$ может быть записана через модель АРCC $(s, m)$ следующим образом [9]:

$\varepsilon_{t}^{2}=\frac{w+(1-\varphi(L))}{(1-\theta(L)-\varphi(L))} v_{t}$,

где $s=\max (r, m), v_{t}=\varepsilon_{t}^{2}-\sigma_{t}^{2}$.

Фрактально проинтегрированный процесс GARCH может быть записан следующим образом:

$$
(1-L)^{2-H} \varepsilon_{t}^{2}=\frac{w+(1-\varphi(L))}{(1-\theta(L)-\varphi(L)) \cdot(1-L)^{-1}} v_{t},
$$

где $H$ - показатель Херста.

$$
\text { Предлагаемая спектрально }
$$

проинтегрированная обобщенная модель с авторегрессионной

гетероскедастичностью имеет вид:

$f^{\varepsilon^{2}}(L) \cdot \omega^{\varepsilon^{2}}(L) \cdot \varepsilon_{t}^{2}=\frac{w+(1-\varphi(L))}{(1-\theta(L)-\varphi(L))} \cdot v_{t}$,

где $\omega^{\varepsilon^{2}}(L)-$ интегрирующий полином от оператора задержки, с помощью которого По автокорреляционной функции можно судить о наличии долгосрочной памяти

процесса.На рисунке 3 изображён график исследуемого процесса с трендовой В результате совместного применения метода "Гусеница"-SSA и метода БоксаДженкинса была построена модель процесса: аппроксимируется временной ряд дисперсии шумов $\varepsilon_{t}^{2}$ в преобразованный сглаженный методом «Гусеница»-SSA временной ряд $w_{t}^{\varepsilon_{t}^{2}}, \quad$ а предварительная структурная идентификация и грубая параметрическая идентификация полинома от оператора задержки $f^{\varepsilon^{2}}(L)$, с помощью которого аппроксимируется сам ряд $\varepsilon_{t}^{2}$ производится при определении коэффициентов рекуррентной прогнозирующей формулы метода «Гусеница»-SSA; $w-$ среднее значение или уровень временного ряда $\varepsilon_{t}^{2}$.

Совместно модели (4) и (5) образуют модель авторегрессии - спектрально проинтегрированного скользящего среднего со спектрально проинтегрированной обобщённой авторегрессионной условной гетероскедастичностью (АРСПСС СПОАРУГ, на англ. яз. ARSIMA SIGARCH).

Для построения предложенных моделей используются стандартные алгоритмы методов "Гусеница"-SSA и БоксаДженкинса. Результаты исследований. Тестирование предложенной модели (3) проводилось на следующих данных, представленных на рисунке 1.

компонентой, построенной методом "Гусеница"-SSA

$$
\begin{aligned}
& \left(1-0.1558 L-0.1509 L^{2}-0.1374 L^{3}-0.1188 L^{4}-0.0982 L^{5}-0.0789 L^{6}-0.0627 L^{7}-\right. \\
& \left.-0.0501 L^{8}-0.0416 L^{9}-0.0367 L^{10}-0.0349 L^{11}-0.0348 L^{12}-\ldots\right) \cdot \nabla y_{t}= \\
& =\frac{\left(-0.3341+0.023 L^{10}\right)}{(1-1.8831+0.9839) \nabla} \cdot \frac{\left(-0.39+0.8047 L+0.5951 L^{2}-0.1958 L^{3}\right)}{\left(1+0.6288 L-0.1067 L^{2}+0.0649 L^{3}+0.2264 L^{4}+0.0987 L^{5}+0.1262 L^{6}\right) \nabla} e_{t} \\
& \text { и получены с её помощью одношаговые } \\
& \text { прогнозы с 95\%-и доверительными } \\
& \text { интервалами: }
\end{aligned}
$$


Использование предлагаемой модели и метода её построения позволило снизить среднеквадратическую ошибку прогнозирования с 0.0361 до 0.0134 по сравнению с применением классической модели АРПСС.

Таким образом, для получения адекватных моделей сложных финансовоэкономических процессов, высококачественных прогнозов необходимо комбинировать модели с разными структурами, включая нелинейные модели, которые являются взаимодополняющими при их конкурентном обучении.

Предлагаемый метод "Гусеница"-SSA - АРПСС - СПОАРУГ является модификацией метода “Гусеница"-SSA c автоматическим отделением долгосрочной памяти от краткосрочной и периодических составляющих и может быть интерпретирована как развитие моделей в пространстве состояний, а предложенная модель АРСПСС - СПОАРУГ, как и модель ARFIMA - FIGARCH, является очередной модификацией модели ARIMA - GARCH, a метод построения предлагаемой модели является развитием метода Бокса-Дженкинса, но для моделирования более широкого класса процессов.

Предложенная модель АРСПСС СПОАРУГ и методика её построения

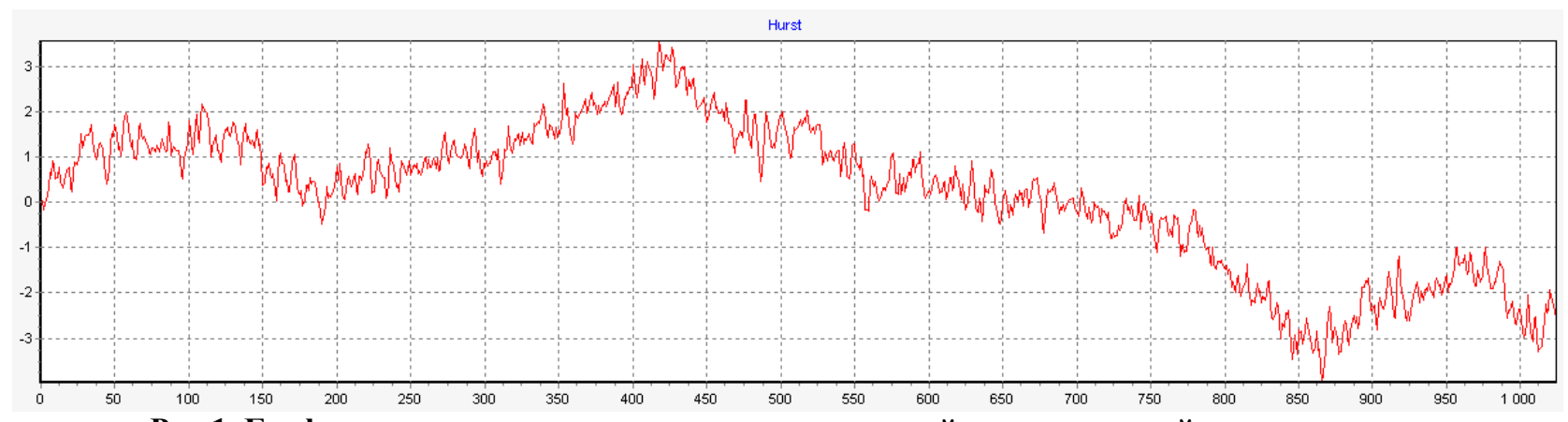

Рис.1. График исследуемого процесса с краткосрочной и долгосрочной памятью является некоторым промежуточным подходом между классическими регрессионными и современными нейросетевыми и более формализованная по выбору структуры, являясь при этом оптимальной по детализации с учетом существующих на сегодняшний день математических и машинных как достоинств и достижений так и недостатков и ограничений.

Подводя итоги описанным выше преимуществам предлагаемой методики, еще раз следует отметить, что основная идея состоит в эффекте синергии, который возникает в результате комбинированного применения двух методов: метода “Гусеница"-SSA и метода Бокса-Дженкинса.

Основным

преимуществом предлагаемой методики построения модели адекватной исследуемому процессу является ее строгая формализация и, следовательно, возможность полной автоматизации всех этапов построения и использования модели. 


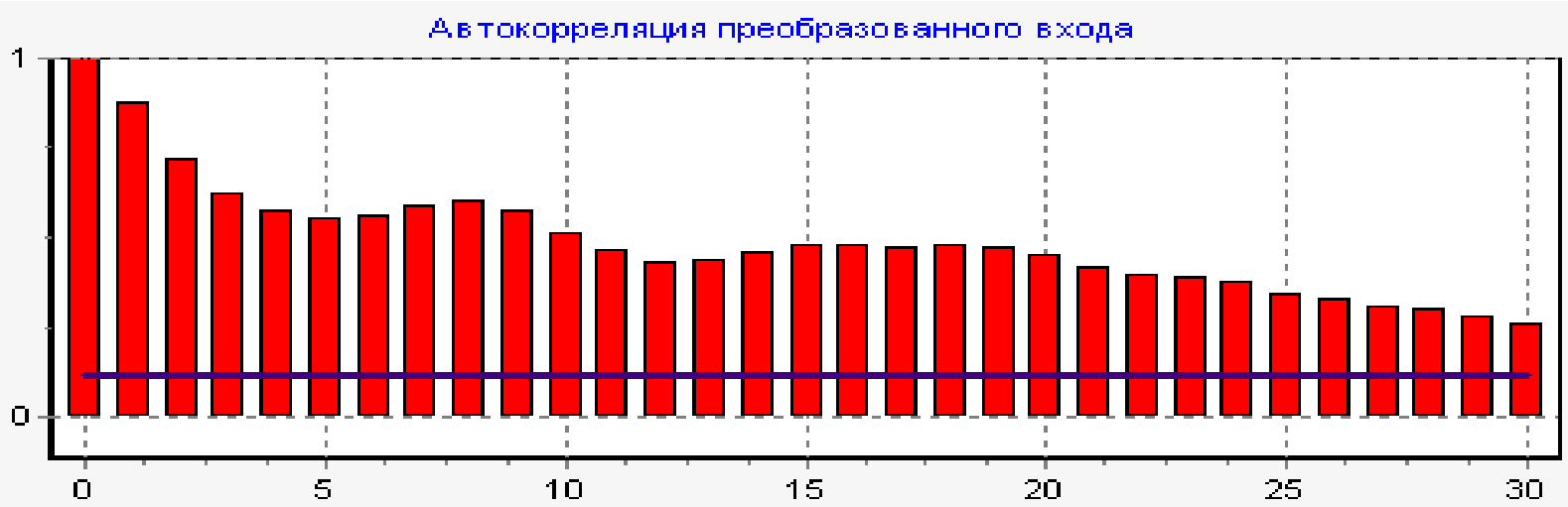

Рис.2. Автокорреляционная функция исследуемого процесса

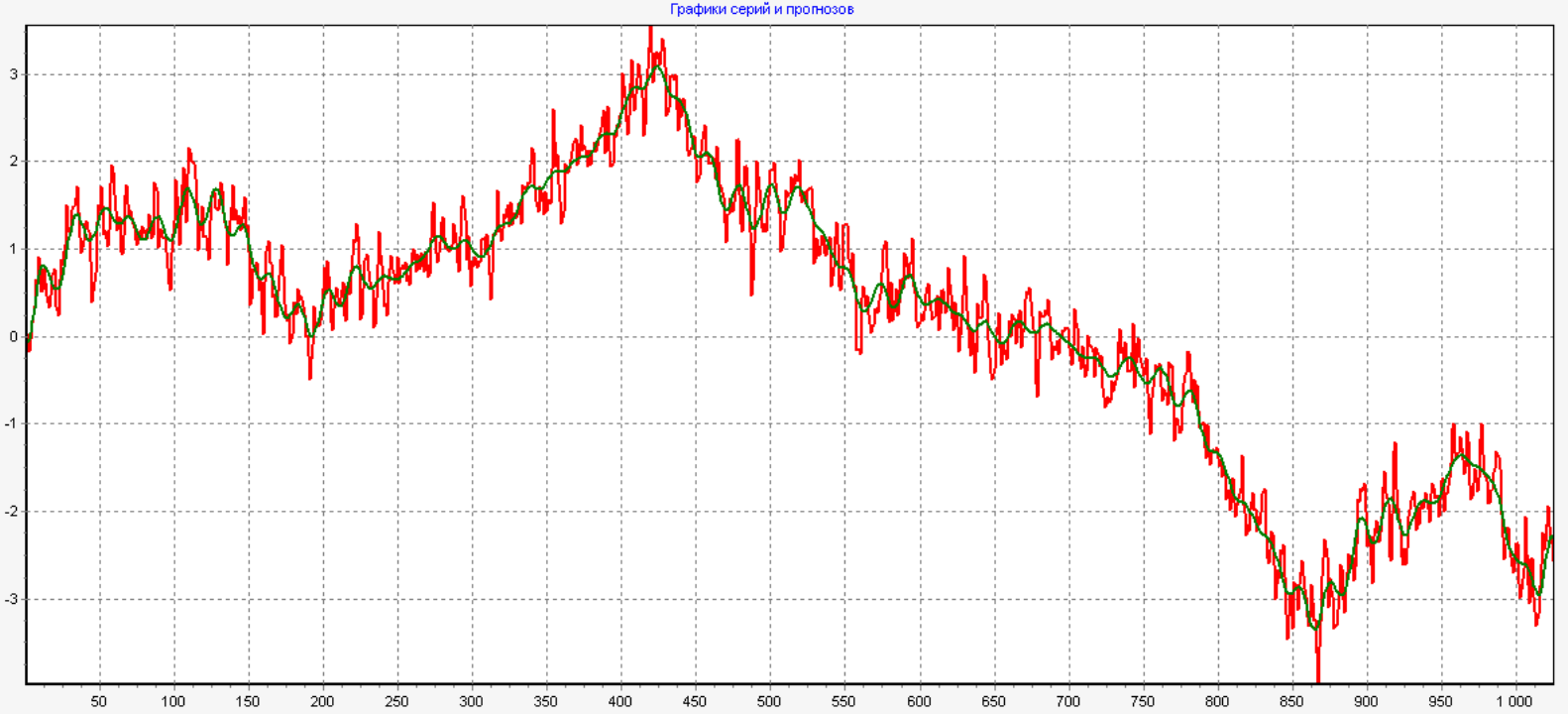

Рис.3. График исследуемого процесса с трендом

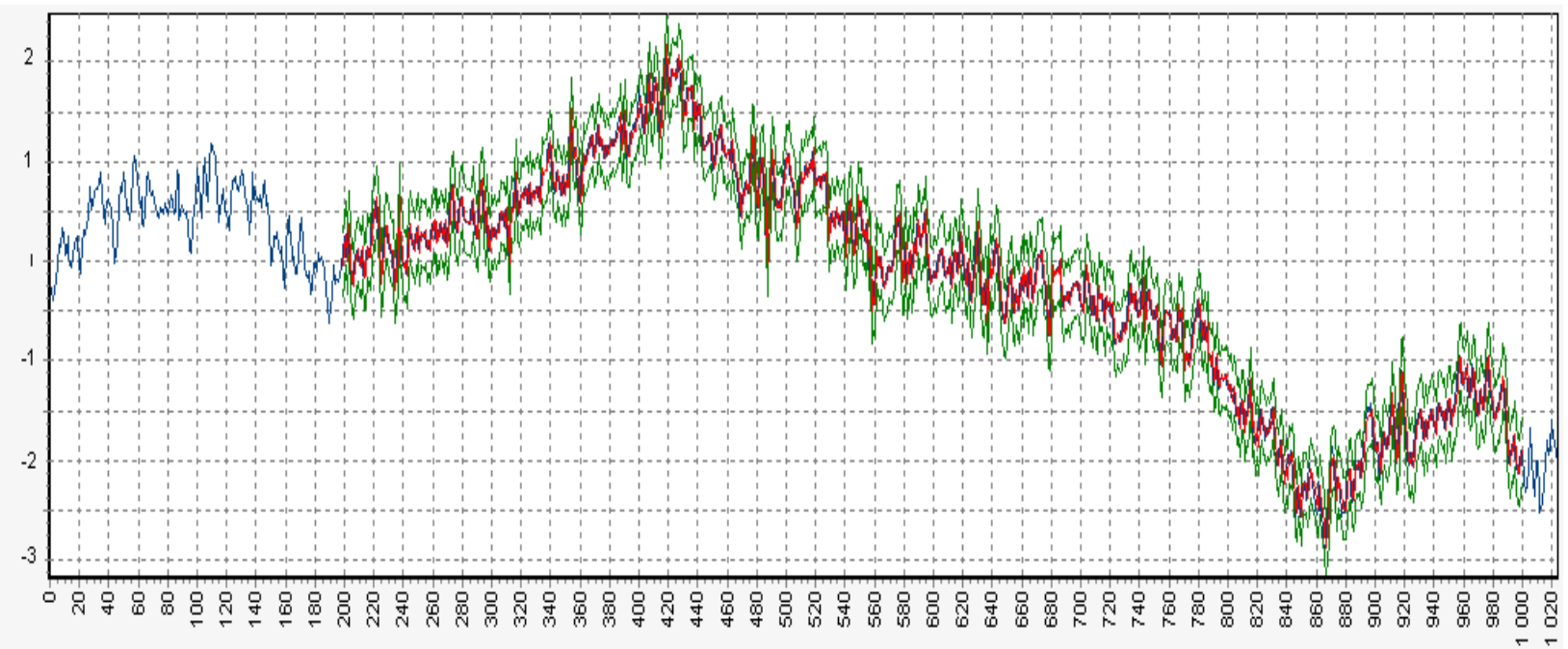

Рис.4. График исследуемого процесса с одношаговыми прогнозами и 95\%-и доверительными интервалами 


\section{Список литературы}

1. Бокс Дж., Дженкинс Г. Анализ временных рядов. Прогноз и управление. Пер. с англ. - М. : Мир, 1974. Вып. II. - 197 с.

2. Granger C.W.J., Joyeux R. An Introduction to Long-Memory Time Series Models and Fractional Differencing // Journal of Time Series Analysis. 1980. N 1(1). P. 15-29.

3. Седов А.В. Моделирование объектов с дискретно-распределёнными параметрами: декомпозиионный подход / А.В. Седов; Южный научный центр РАН. - М. : Наука, 2010. - 438 c.

4. Щелкалин В.Н., Тевяшев А.Д. «Автоматизированная система анализа и оперативного прогнозирования процессов потребления целевых продуктов в жилищно-коммунальном хозяйстве». Международный конкурс инновационных проектов “Харьковские инициативы”, 2010.

5. Щелкалин В.Н., Тевяшев А.Д. Модель авторегрессии - спектрально проинтегрированного скользящего среднего со спектрально проинтегрированной обобщенной авторегрессионной условной гетероскедастичностью для

моделирования, фильтрации, прогнозирования и управления процессами в современных системах автоматизации. // Труды Международной научнопрактической конференции «Передовые информационные технологии, средства и системы автоматизации и их внедрение на российских предприятиях» AITA2011. Москва, $4-8$ апреля 2011 г. М.: Институт проблем управления им. В.А. Трапезникова РАН, 2011. с. 996 $-1022$.

6. Евдокимов А. Г., Тевяшев А. Д. Оперативное управление потокораспределением в инженерных сетях. - Х. : Вища школа, 1980. - 144 c.

7. Голяндина Н. Э. Метод «Гусеница»SSA: прогноз временных рядов: Учеб. пособие. - СПб., 2004. - 52 с.

8. Перцовский О.Е. Моделирование валютных рынков на основе процессов с длинной памятью: Препринт WP2/2004/03 - М.: ГУ ВШЭ, 2003. - $52 \mathrm{c}$.

9. Bollerslev T. Generalized autoregressive conditional heteroscedasticity // Journal of econometrics. - 1986/ - V. 31. - PP. 307-327.

\title{
Аннотация
}

Виталий Щелкалин

\section{МЕТОД “ГУСЕНИЦА"-SSA - АРПСС - СПОАРУГ И МОДЕЛЬ АРСПСС - СПОАРУГ ДЛЯ АНАЛИЗА И ПРОГНОЗИРОВАНИЯ ФИНАНСОВО- ЭКОНОМИЧЕСКИХ ВРЕМЕННЫХ РЯДОВ}

\begin{abstract}
B работе производится дальнейшее развитие метода Бокса-Дженкинса построения моделей $u$ усовершенствование моделей авторегрессии проинтегрированного скользящего среднего (АРПСС), разработанных и успешно используемых около сорока лет в различных отраслях науки и техники и остающихся по сей день одними из наиболее эффективных моделей для моделирования и прогнозирования финансово-экономических временных рядов, превосходя своих конкурентов по иелому ряду критериев, таких как: экономность по количеству параметров, трудоемкость алгоритмов построения моделей $и$ ресурсоемкость их реализащии, формализация $u$ автоматизируемость их построения. Предложена очередная модификаџия моделей ARIMA и GARCH.
\end{abstract}


Ключевые слова: моделирование, фильтрачия, прогнозирование, управление, модель АРПСС, метод «Гусенииа»-SSA - АРПСС - СПОАРУГ, модель АРСПСС, модель АРСПСС-СПОАРУГ, гетероскедастичность, метод Левенберга-Марквардта.

\section{Summary}

Vitaliy Shchelkalin

\section{"CATERPILLAR"-SSA - ARIMA - SIGARCH METHOD AND ARSIMA - SIGARCH MODEL FOR ANALYSIS AND FORECASTING OF FINANCIAL AND ECONOMIC TIME SERIES}

In this paper the further development of the Box-Jenkins method for modeling and improvement of autoregressive - integrated moving average (ARIMA) models developed and successfully used about forty years in various branches of science and technology and remaining in present time as one of the most efficient models for modeling, forecasting of financial and economic time series, exceeding their own rivals on whole row of criterions, such as: economy on the number of parameters, the complexity of algorithms for modeling and resource intensity of their implementation, on formalization and automation of their construction is produced. Proposed another modification of the models ARIMA and GARCH.

Key words: modeling, filtering, forecasting, management, ARIMA model, "Caterpillar»SSA - ARIMA - SIGARCH method, ARSIMA model, ARSIMA - SIGARCH model, heteroskedasticity, Levenberg-Marquardt method. 


\section{MICT}

Сторощук Б. Д., Дячук М. П. Й. А. Шумпетер І Чернівецький університет.........................3

Білоцерківець В. В. Критерії визначення нової економіки: технологічний аспект...............12

\section{ФІНАНСИ}

Науменкова С. В., Перконос П. П. Еволюція теоретичних підходів до розкриття змісту та

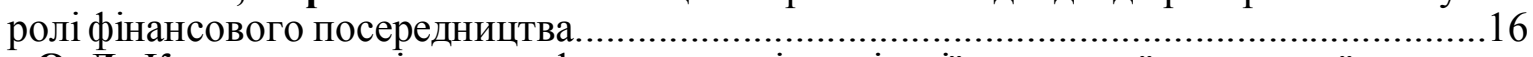

Рожко О. Д. Концептуальні основи формування і реалізації державної податкової політики.

Третякова О. В., Онопко М. О. Роль держави в соціалізації економіки: фінансовий аспект.....

Свердан М. М. Бюджетні видатки: механізм функціонування та характер реалізації в

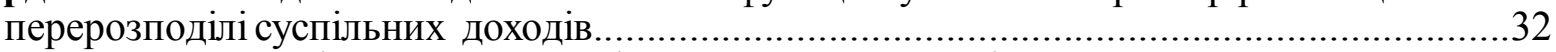

Коцабюк Р. Г. Управління власним капіталом банку в Україні...........................................39

Легкоступ I. І. Фіскальна децентралізація та їі необхідність в Україні...............................45

Жебчук Р. Л. Результативність планування видаткової частини бюджету як основа ефективного бюджетного менеджменту.....................................................................53

Бойко О. В. Вплив макроекономічних чинників на функціонування та реформування

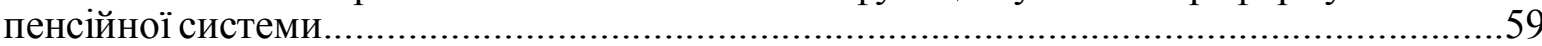

Ткач С. В. Особливості валютного курсоутворення в Україні.........................................64

\section{МАРКЕТИНГ}

Кошкаров С. А. Економічний аналіз основних ознак чинного кооперативного законодавства.

Струлєв О. О. Життєвий цикл об`єктів промислової нерухомості як товарів промислового

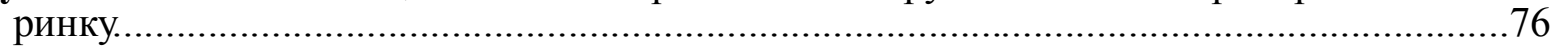

Антохов А. А., Клевчік Л. Л. Аналіз надання та споживання освітніх послуг вищої освіти

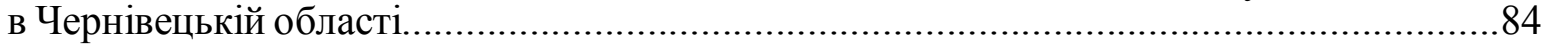

\section{ПІДПРИЕМСТВО І ПІДПРИЕМНИЦТВО}

Карюк В. І. Організаційно-економічний механізм активізації інноваційної діяльності

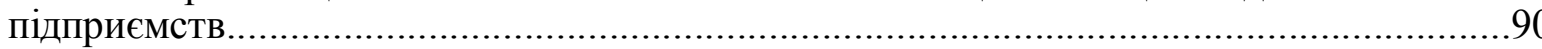

Запухляк В. М., Грунтковський В. Ю. Проблеми та перспективи розвитку соціально відповідального безнесу в Україні.

Белінський П. І., Загриновський М. В., Рубенок Т. М. Єфективність роботи підприємства на давальницькій сировині та фінансово-економічна безпека його діяльності. ак Л. І. Зарубіжний та вітчизняний досвід розвитку і функціонування підприємств

Шпак Л. І. Зарубіжний та вітчизняний досвід розвитку і функціо
малого бізнесу в контексті оновлення української економіки. .106

Кошкаров В. С. Оптимізація інформаційного забезпечення переробного підприємства. 
Збродська О. В. Чинники використання ресурсного потенціалу сільськогосподарських підприємств на радіаційно забруднених територіях................................................116

Каліна І. І., Шуляр Н. М. Потенціал інформації галузі зв `язку в контексті конкурентного середовища

Якобчук В.П., Кащук К.М. Формування і розвиток агроінноваційних струтур в Україні: проблеми та перспективи

\section{МІЖНАРОДНА ЕКОНОМІКА}

Михайлина Д. Г. Сучасні імперативи організаційної реструктуризації міжнародних корпорацій

Фищук І. М. Українські компанії на міжнародних фондових ринках.

Фреяк А. В. Роль транскордонного співробітництва у регіональноиу розвитку та інтеграційних процесах

Товарницька В. С. Аналіз показників експорту та імпорту товарів як факторів формування конкурентоспроможності економіки України в умовах глобалізації.....

\section{ЕКОНОМІЧНА КІБЕРНЕТИКА}

Піскунова О. В. Гнучкість малого підприємства та її моделювання. 160

Вінничук О. Ю. Системний підхід в автоматизації механізму управління підприємстов.

Щелкалин В. Н. Метод «Гусеница»-SSA - АРПСС-СПОАРУГ и модель АРСПСССПОАРУГ для анализа и прогнозирования финансово-экономических временных рядов. 